\title{
Patiënt, privaat en privacy : de stoelgang als gezondheidswetenschappelijk probleem
}

Citation for published version (APA):

van Bruggen, H. J. (1991). Patiënt, privaat en privacy : de stoelgang als gezondheidswetenschappelijk probleem. [Doctoral Thesis, Maastricht University]. De Tijdstroom.

https://doi.org/10.26481/dis.19910314hb

Document status and date:

Published: 01/01/1991

DOI:

10.26481/dis.19910314hb

Document Version:

Publisher's PDF, also known as Version of record

\section{Please check the document version of this publication:}

- A submitted manuscript is the version of the article upon submission and before peer-review. There can be important differences between the submitted version and the official published version of record.

People interested in the research are advised to contact the author for the final version of the publication, or visit the DOI to the publisher's website.

- The final author version and the galley proof are versions of the publication after peer review.

- The final published version features the final layout of the paper including the volume, issue and page numbers.

Link to publication

\footnotetext{
General rights rights.

- You may freely distribute the URL identifying the publication in the public portal. please follow below link for the End User Agreement:

www.umlib.nl/taverne-license

Take down policy

If you believe that this document breaches copyright please contact us at:

repository@maastrichtuniversity.nl

providing details and we will investigate your claim.
}

Copyright and moral rights for the publications made accessible in the public portal are retained by the authors and/or other copyright owners and it is a condition of accessing publications that users recognise and abide by the legal requirements associated with these

- Users may download and print one copy of any publication from the public portal for the purpose of private study or research.

- You may not further distribute the material or use it for any profit-making activity or commercial gain

If the publication is distributed under the terms of Article $25 \mathrm{fa}$ of the Dutch Copyright Act, indicated by the "Taverne" license above, 
Patiënt, privaat en privacy 
" 


\section{Patiënt, privaat en privacy}

De stoelgang als gezondheidswetenschappelijk probleem

\section{Proefschrift}

ter verkrijging van de graad van doctor aan de Rijksuniversiteit Limburg te Maastricht, op gezag van de Rector Magnificus, Prof. mr. M.J. Cohen, volgens het besluit van het College van Dekanen, in het openbaar te verdedigen

op donderdag 14 maart $199 \mathrm{l}$ om 14.00 uur

door

Harry van der Bruggen

1991

Uitgeversmaatschappij De Tijdstroom

Lochem 
(19) 199 by Uitgeversmatschappij De Tijdstroom bv, Lochem

Alle rechten woorbehouden. Niets uit deze uitgave mag worden verveelvoudigd, opgeslagen in een gevutomatiseerd gegevensbestand, of openbaar gemakt, in enige vorm of op enige wijze, hetzij elektronisch, mechanisch, door foiokopieèn, opnamen, of enig andere manier, zonder vooraf gaande schriftelijke toestemming wan de uitgever.

Voot zover het maken wan kopieèn uit deze uitgave is toegestain op grond van artikel $16 \mathrm{~B}$ Autteurswet 1912 $j^{\text {il }}$ het Besluit van 20 juni 1974, St.b. 351, zoals gewijzigd bij het Besluit van 23 augustus 1985, St.b. 471 en artikel 17 Auteurswet 1912 , dient men de daarvoor wettelijk verschuldigde vergoedingen te voldoen aan de Stichting Reprorechu (Postbus 882, 1180 AW Amstelveen). Voor het ovememen van gedeelte(n) uit deze uitgave in bloemlezingen, readers en andere compilatiewerken (artikel 16 Auteurswet 1912) dient men zich tot de uitgever te wenden. 


\section{Promotores:}

Prof. dr. H. Philipsen

Prof. dr. J.I.C.B. Bremer

Copromotor:

Dr. R.J.G. Halfens

Beoordelingscommissie:

Prof. dr. H. Huijer Abu-Saad, voorzitter

Prof. dr. H.F.J.M. Crebolder

Prof. dr. H.A.M.J. ten Have

Prof. dr. R.A. Janknegt

Prof. dr. L.J. Menges 


\section{Inhoudsopgave}

\section{Inleiding 11}

1. Stoelgangproblemen van ziekenhuispatiènten I1

2. Literatuurverkenning 12

3. Onderzoeksstrategieen 14

4. Indeling van dit proefschrift 14

1 Privaat en privacy in cultuur-historisch perspectief 17

1.1 Inleiding 17

1.2 Privatus versus publicus 20

1.3 Afzondering uit gemaksoverwegingen en/of uit schaamte 20

1.4 Verschuiving van de schaamtegrens 22

1.5 Een 'nieuwe intimiteit' 24

1.6 Begrenzing van privacygewoeligheid 25

1.7 Discussie en samenvatting 27

2 Privacy: begripsverheldering en consequenties voor de patiënt 31

\section{Inlleiding 31}

2.2 Privacy: een poging tot een begripsomschrijuing 32

2.3 Privacy: een homoniem? 38

2.4 Aspecten van privacy 39

2.5 Conclusies en suggesties 43

3 Het normale defecatiepatroon 47

3.1 Inleiding 47

3.2 Vraagstelling 48

3.3 Literatuurresearch 48 
3.4 De keuze woor humaan-biologische kenmerken 51

3.5 Opzet en uitwoering van het onderzoek 51

3.6 Onderzoeksresultaten: het defecatiepatroon gebaseerd op gegevens omtrent de stoelgang 56

3.7 Defecatiepatroon: samenhang van variabelen 63

3.8 Stabiliteit per persoon van het defecatiepatroon 65

3.9. Structuren van het normale defecatiepatroon 69

3.10 Samenvatting, discussie en conclusies 70

4 Determinanten van beleving van de stoelgang in een gezonde populatie 73

4.1 Beleving van de stoelgang: mogelijke determinanten 73

4.2 Opzet van het onderzoek 75

4.3 Vier belevingsvarianten ten aamzien van ontlasting 75

4.4 De onafhankelijke variabelen 78

4.5 Onderlinge structuur tussen onafhankelijke variabelen 81

4.6 Problematische beleving van de stoelgang: differentiatie naar geslacht en naar leeftijd 84

4.7 Discussie en conclusies 87

5 Privacygevoeligheid van ziekenhuispatiënten bij de stoelgang 89

5.1 Inleiding 89

5.2 Operationalisering 'Privacygevoeligheid' 90

5.3 Vraagstellingen 91

5.4 Opzet en verloop van het onderzoek 92

5.5 PrivacyGevoeligheids Vragenlijst, in vier subschalen 93

5.6 Interne consistentie van de PGV 100

5.7 Sociaal-demografische context van privacygevoeligheid 102

5.8 Discussie en conclusies 103

6 Bezorgdheid omtrent de stoelgang in het ziekenhuis 105

6.1 Onderzoeksvraagstellingen 105

6.2 Bezorgdheid omtrent de stoelgang in het ziekenhuis: mogelijke determinanten 106

6.3 Opzet en methode van onderzoek 110

6.4 Operationalisering van de variabelen 111

6.5 Onderzoeksresultaten 114

6.6 Discussie en conclusies 118 
7 Betrouwbaarheid van patiënteninformatie bij ziekenhuisopname 121

7.1 Beperkingen van zelfrapportage van patëënten 121

7.2 Opzet en verloop van het onderzoek 123

7.3 Resultaten met betrekking tot de VOEG-lijst 126

7.4 Resultaten ten aanzien van het defecatiepatroon 128

7.5 Discussie en conclusies 131

8 Conclusies en aanbevelingen 135

8.1 Samenvatting van de resultaten 135

8.2 Methodologische reflecties 137

8.3 Theoretische overwegingen 140

8.4 Praktische consequenties en aanbevelingen 142

Summary 145

Sommaire 149

Literatuur 153

Bijlagen 163

Bijlagen bij hoofdstuk 3164

3.1 Dagboek ter registratie van het normale ontlastingspatroon 164

3.2 Factorladingen op twee factoren, na varimaxrotatie 165

3.3 Pearsons correlatiecoëfficiënten, naar vier subgroepen 166

Bijlage bij hoofdstuk 4168

4.1 Pearsons correlatiematrix 168

Bijlage bij hoofdstuk $5 \quad 170$

5.1 Items niet opgenomen in de data-analyse 170

Dankwoord 173

Curriculum Vitae 175 



\section{Inleiding}

\section{Stoelgangproblemen van ziekenhuispatiënten}

De stoelgang, zeker wanneer deze niet vanzelfsprekend verloopt, behoort tot het gesprek van de dag van patiënten op verpleegafdelingen van ziekenhuizen. Op de patiëntenkamers, in het dagverblijf, de conversatiezaal, worden de problemen met de stoelgang breed uitgemeten.

Defecatieproblemen in het ziekenhuis doen zich voor gerelateerd aan uiteenlopende situaties. Soms zijn zij rechtstreeks gevolg van de aandoening waarvoor patiënten zijn opgenomen, zoals uitwendige of inwendige hemorroiden, dan weer bijverschijnsel van een therapie, bijvoorbeeld hevige diarree bij een kuur met antibiotica. Vaak ook lijken voor de ontlastingsproblemen geen aperte oorzaken of redenen aanwezig; de ziekte als ingrijpende bestaansverandering en/of het ziekenhuisverblijf als veranderde leefsituatie lijken dan door te werken tot in opmerkelijke veranderingen in het defecatiepatroon in het ziekenhuis ten opzichte van de situatie thuis. Deze veranderingen kunnen soms de faeces zelf betreffen bijwoorbeeld in de vorm van diarree, dan wel, vaker, het ontlastingsbeloop, bijvoorbeeld een verminderde frequentie van de stoelgang en het optreden van, soms hevige, obstipatie. 'Het zijn klachten die men hoort bij heel veel mensen die in het ziekenhuis zijn opgenomen om zeer uiteenlopende redenen, die vaak helemaal niets van doen hebben met aandoeningen van het spijsverteringsorgaan' (Mauchamp 1983, vert. HvdB).

Verpleegkundigen zijn over het algemeen, beroepshalve, als zorgverleners, met deze problematiek vertrouwd, zij het dat er in de dagelijkse praktijk van de zorgverlening verschillend over wordt geoordeeld en dienovereenkomstig verschiltend mee wordt omgegaan. Gesprekken met verplegenden en verzorgenden maken dit duidelijk. 'Patiënten klagen voortdurend over obstipatie; iedereen die op de afdeling verschijnt vallen ze lastig met hun problemen in deze.' 'Op onze afdeling zijn er geen klachten: op verzoek geven wij gelijk een klysma.' 'Problemen ontstaan', aldus een afdelingshoofd, 'als je dagelijks gaat vragen of de mensen ontlasting hebben gehad. Ik praat er nooit over en ik hoor dan ook nooit iets over problemen.'

Deze kwesties vormden de eerste aanleiding tot de hieronder beschreven deelonderzoeken, waarbij de belangstelling niet zozeer maar pathologische processen van het spijsverteringsorgaan uitging, als wel naar de stoelgang als menselijke, 'dagelijkse" gebeurtenis. 


\section{Literatuurverkenning}

Autobiografische geschriften en journalistiek werk van (gewezen) patienten, hun familieleden of naststaanden, alsook van verpleegkundigen of verzorgenden (met name hun ervaringen als patiënt in het ziekenhuis), laten geen twijfel bestaan over de feitelijkheid van bowengenoemde problematiek. Een enkel citaat ter illustratie.

Anne de Vogué, die de reacties bundelde op haar artikel in de Nouvel Observateur over har ziekenhuiservaringen (1975), doet verslag van een oude dame die, in het xiekenhuis herstellende, wacht op een plaats in een bejaardenoord.

Zij was ongerust. Zij vermoedde vaag dat er buten haar om iets bekokstoofd werd. Zii kreeg er buikkrampen van. Verschrikkelike buikkrampen. Binnen drie dagen was ze een vod. Haar familieleden deden alsol zil haar incontinentie niel in de gaten hadden, besprenkelden haar met eau de cologine en gingen snel weer weg, na een klein kusje op het voorhoofd. Zij beklaagde zich niet tegenover hen. (.). Was het bezoekuur voorbij. dan was de oude dame weer het wegwerpprodukt wan de afdeling. Zij werd verstoten door ledereen: de patienten met de verfinde neus, de verpleegkundigen die ten einde raad waren mel deze bejaarde baby, de antsen die ambtshalve de wule klusjes aan de verpleging overlaten. Soms probeerde zif, in haar uiterste wanhoop, iets te doen om zich vast le klampen aan de wereld der levenden. Zij veegde haar achterwerk af met alles wat haar toevallig in handen kwam: haar servet, een stuk kleenex, haar bovenlaken. Zij maakte alles smerig en spreidde daarmee ten toon wat zij verborgen had willen houden. Den kwamen uit haar bed haar bevulide vingers tevcorschiin waarmee ze tastend zocht naar haar bril, om lets te kunnen doen aan de wanorde. Op zekere morgen werd haar haar bril afgenomen. Te waak maakte ze die maar vuil. Zo bleef zij alleen achter, in de mist van haar bijziendheid. Geheel en al overgeleverd aan die oncontroleerbare anus. (De Vogüé \& Grasset 1975, vert. HvdB).

Gevoelens van afhankelijkheid, wan schaamte en vernedering kunnen door de verplegenden nog worden versterkt. Sonia Grasset (1975) citeert de ervaringen van een collega-verpleegkundige die als patiënte in een zilekenhuis was opgenomen:

Het verplegend personeel grijpt de ontlasting van de patiënt als middel aan om deze te vernederen en te kleineren. De attitude van de verpleegkundige in deze is opmerkelikk. (...) Heb her nooit bîj stilgestaan hoe de patiènt dit zou ervaren. Totdat ik zelf patiënt werd en me zeer vernederd heb gevoeld toen ik moest bellen om de po. (De Vogüe \& Grasset 1975, vert. HvaB)

In geval van uitscheidingsproblemen is er dikwijls een interactie aanwijsbaar tussen lichamelijke ontregeling. persoonlijke gevoelens en gedrag. De stoelgang en problemen dienaangaande in de thuissituatie gaan, na opname in het ziekenhuis, al gauw gepaard met gevoelens van afhankelijkheid, vemedering en schaamte. Kunnen gevoelens van onmacht bij de patient en van (over)macht bij de verpleegkundige in het algemeen al in hun onderlinge verthoudingen tot uiting komen en de interactie beinwloeden, in het bijzonder lijkt dit rond defecatieproblemen het geval.

In de (auto)biografische literatuur zijn alan stoelgangproblemen globaal genomen drie dimensies te herkennen. De stoelgang heeft lichamelijke, functionele kanten: de 'fysiologie van de ontlasting'. Voorts zijn er belevingsfactoren aan te onderkennen. Tenslotte is er ook een maatschappelijke dimensie: de stoelgang vindt plaats in een sociale context, al was het maar vanwege de algemene wens tot afzondering. 
Inventarisatie van wetenschappelijke literatuur over 'defecatiaproblemen wan ziekenhuispatienten', met behulp van het Medline-search-systeem betreffende het medische en het gedragswetenschappelijke bestand over de jaargangen $1975-89$, leverde ongeveer 600 titels op. Daaronder bleken nawelijks of geen bijdragen vanuit de verpleging. Niet alle tijdschriften waarin verpleegkundigen publiceren, maken overigens deel uit van het bestand dat via Medline kan worden geraadpleegd. Uit verder onderzoek, ditmaal aan de hand van de International Nursing Index, en tenslotte met behulp van handmatige analyse van ruim 130.000 pagina's (Nederlands-, Frans-, Duitsen Engelstalige) verpleegkundige vakliteratuur, bleek dat defecatieproblemen niet of nauwelijks binnen de belangstellingssfeer van de meeste tijdschriften wallem: slechts 80 pagina"s $(0,06 \%)$ van het totale aantal bladzijden is gewijd aan de uitscheiding van faeces. Verplegingswetenschappelijke tijdschriften (International Journal of Nursing Studies, Nursing Research, Research in Nursing and Health) besteden er hoegenaamd geen aandacht aan. In de beroepstijdschriften, zoals Nursing Times, American Journal of Nursing, Soins, is de aandacht voor dit onderwerp eveneens minimaal, zij het niet geheel afwezig.

Ook voor aspecten van defecatieproblemen die de menselijke beleving betreffen en die het patiëntengedrag beinvloeden, bestaat in de verpleegkundige vakliteratuur nagenoeg geen aandacht: geen artikelen over privacy, over schaamte en gêne, afhankelijkheid, vernedering, over macht en onmacht, noch over de wijze waarop deze emoties het stoelganggedrag beïnvloeden.

Leven deze problemen misschien wel bij verpleegkundigen, maar zou deze problematiek niet passen binnen het publikatiebeleid van de verpleegkundige vakbladen? Als over menselijke aspecten van de stoelgang in het ziekenhuis door verplegenden wordt nagedacht, moeten daaromtrent aanwijzingen zijn te vinden in teksten die door (leerling-)verpleegkundigen in het kader van basis- of vervolgopleidingen worden geproduceerd. Uit onderzoek bij instellingen in Nederland van hoger (45) en middelbaar (5) verpleegkundig beroepsonderwijs, alsook bij een steekproef onder inservice-opleidingen, bleek echter dat eventuele belangstelling voor uitscheidingsproblematiek geen expliciete weerslag vindt in scripties, verpleegverslagen, werkstukken en dergelijke.

De conclusie lijkt gewettigd dat de Nederlandse verpleegkundigen in basis-en vervolgopleidingen niet of nauwelijks belangstelling aan de dag leggen voor hel fenomeen van de stoelgang.

Dit beeld komt overeen met de weerspiegeling van het fenomeen excretie in de Nederlandse leerboeken verpleegkunde - in ieder geval de leerboeken tot 1985: Zuster Agathe 1969 16 , Van der Moolen \& Quanjer 1967". Bouwhuizen 1972, Van den Bergh-Braam 1979, alsook in leerboeken psychiatrische verpleegkunde: Hamer \& Haverkate $1950^{8}$, Hamer \& Tolsma $1964^{4}$, en Kramer 1968 (cf: Van der Bruggen, 1985). De visie op de menselijke uitscheiding in de geanalyseerde leerboeken wordt bepaald door een medische optiek. De activiteiten van de verplegenden ten aanzien van de excretie krijgen vrijwel uitsluitend aandacht wat betreft excretieprodukten, en lijken door verplegenden en verzorgenden voornamelijk uitgevoerd te (moeten) worden ten behoeve van diagnostiek en therapie, dat wil zeggen als de "verlengde arm" van de behandelende arts. 


\section{Onderzoeksstrategieën}

Wat is de aard en de omvang van defecatieproblemen van patienten in het ziekenhuis? Op deze wijze geformuleerd lijk de vraggstelling breed en het onderzoeksterrein onoverzichtelik. De onderzoeksactiviteiten, die aanvankelijk als op zichzelf stande deelonderzoeken werden ondernomen ter bestudering van uiteenlopende aspecten van de problematiek, en warover hier wordit gerapponteerd, zijn explorerend en divers van aard. Exploterend omdat, gelet op de bijna afwezigheid van literatuur op dit terrein van onderzoek, veelal het theoretisch kader ontbreekt waarbinnen hypothesen formuleren en toetsen zinvol is. Een theoretisch kader of conceptueel model werd veelal per bestudeerd deelaspect geformuleerd.

Divers, witeenlopend van aard zijn de gevolgde onderzoeksstrategieèn vanwege de witteenlopende aard van de diverse aspecten van het onderzoeksonderwerp. Aan 'Stoelgangproblemen van ziekenhuispatiènten" zijn aspecten te onderkennen die zich lenen voor overwegend $k$ wantitatieve benadering: de fysiologische aspecten van het

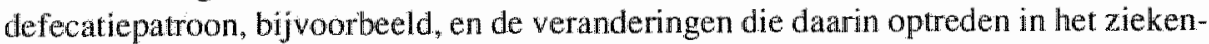
huis. Andere aspecten zijn minder gemakkelijk objectiveerbaar, bijvoorbeeld de zorg die de stoelgang iemand kan baren, thuis of in het ziekenhuis: naast kwantitatieve bewerking wan het onderzoeksmateriaal kan meer inzicht in het bestudeerde onderwerp worden verk regen met behulp van een interpretatief getinte benadering. Weer andere aspecten tenslotte lenen zich bij uitstek voor een kwalitatieve benadering, bijwoorbeeld iemands behoefte aan privacy bij de ontlasting.

De successievelijk gevolgde uiteenlopende benaderingswijzen behoeven methodologische objectiviteit niet te verminderen, integendeel. In overeenstemming met Smalings manteldefinitie van methodologische objectiviteit, zijn in deze term twee 'betekeniskernen' te onderscheiden (Smaling, 1988). Ten eerste is er het negatieve betekenismoment: objectiviteit betekent dan dat de methode niet leidt tot fouten, vertekeningen, dwalingen, verstoringen. Het positieve betekenismoment daarentegen impliceert dat de onderzoeker "het object van studie laat spreken". Smaling opteert vervolgens voor een conjunctief gebruik van de twee betekeniskernen: 'recht doen aan het object van studie' betekent dat èn fouten vermeden moeten worden èn dat men het object moet laten spreken. "Het benadrukken van zowel het positieve als het negatieve betekenismoment vormt een weermiddel tegen ontsporingen van het objectiviteitsstreven als gevolg van het eenzijdig beklemtonen van én van de betekeniskernen" (Smaling, 1988).

\section{Indeling van dit proefschrift}

De hier gepresenteende deelonderzoeken hebben betrekking op successievelijk drie te onderscheiden dimensies van de stoelgangproblematiek. De lichamelijke dimensies van dit 'dagelijkse' gebeuren worden bestudeend in deelonderzoek naar humaan-biologische aspecten van het defecatiepatroon. Belevingsaspecten komen aan de orde in onderzoeken naar belevingsdeterminanten van de stoelgang, zowel thuis alls in het ziekenhuis. De sociale dimensie van de uitscheiding komt aan de orde in deelonder- 
zoeken naar privacygewoeligheid bij de stoelgang.

Overigens staan de hier gepresenteerde deelonderzoeken, althans de neeste, min of meer los van elkaar. Achtereenvolgens worden de deelonderzoken yepresenteerd as volgt.

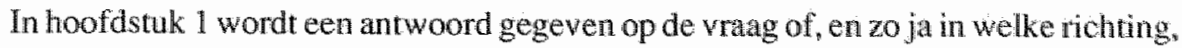
gevoelens van en behoefte aan privacy bij de stoelgang zich hebben ontwikkeld in onze. westerse samenleving. Het 'privaat', en de ontwikkeling van stoelganggedrag, wordt beschouwd in relatie met privacy en de ontwikkeling van privacybehoeften en -voorzieningen, toegespitst op de situatie waarin de ziekenhuispatient verkeert. Het theoreiisch perspectief van deze studie is dat van de "histoire-present' (Tollenbeek, 1990).

In hoofdstuk 2 wordt onderzocht welke betekenisdimensies te onderkennen zajn aan de begrippen privacy en privacygevoeligheid, eveneens toegepitst op de situatie van de ziekenhuispatient. De methodologie hier gevolgd is de conceptverheldering zoals binnen de verplegingswetenschap ontwikkeld en gebruikt door Norris (1982) en Walke. \& Avant $\left(1988^{2}\right)$. Binnen deze strategie neemt de fenomenologische beschrijving een belangrijke plats in.

Hoofdstuk 3 en 4 zijn gewijd aan het "normale defecatiepatroon". In hoofdstuk 3 worden enkele humaan-biologische kenmerken van het "normale defecatiepatroon" in een gezonde populatie beschreven. In hoofdstuk 4 wordt antwoord gegeven op de vraag: Hoe is de beleving van de stoelgang en welke zijn de determinanten van beleving van de stoelgang in een gezonde populatie? Het betreft twee rapportages van een en hetzelffle deelonderzoek, gehouden in een gezonde populatie en die tot stand kwam door middel van 'convenient sampling". Voor de dataverzameling is gebruik gemaakt van de dagboekmethode.

Op basis var de conceptuele analyse in hoofdstuk 2 werd een instrument ontwikkeld voor meting van privacygevoeligheid bij de stoelgang op de verpleegafdeling, de PrivacyGevoeligheids Vragenlijst. In hoofdstuk 5 wordt de vraag beantwoord of bij empirische toetsing aan dit meetinstrument de vier dimensies zijn te onderkennen die bij theoretische analyse zijn verondersteld. Vervolgens wordt antwoord gegeven op de vraag of, en zo ja in welke mate, de PrivacyGevoeligheids Vragenlijst in zijn totaliteit alsook voor wat de vier subschalen betreft betrouwbaar en valide is.

Hoofdstuk 6 is gewijd aan 'Defecatieproblemen van ziekenhuispatiënten" in het algemeen. Vragen die worden gesteld en beantwoord zijn: In welke mate tonen patiënten in het ziekenhuis zich bezorgd over de stoelgang? Welke veranderingen treden op in het defecatiepatroon na ziekenhuisopname? Kan samenhang worden vastgesteld tussen deze veranderingen en de eerder genoemde bezorgdheid over de stoelgang? Hangen met deze bezorgdheid eventueel andere factoren samen? Het onderzoek werd alanvankelijk opgezet als een replicatiestudie, als herhaling namelijk van het onderzoek natar 'Bowel function in hospital patients' wan Wright (1974). In overleg met een onderzoeksgroep in het verpleegkundig Hoger Beroepsonderwijs werden aan de oorspronkelijke vraagstellingen enkele andere toegewoegd, zodat het hier gerapporteerde onderzoek beter als constructieve of innovatieve replicatie angeduid kan worden (Conelly, 1986).

Tenslotte wordt in hoofdstuk 7 werslag gedaan wan instrumenteel onderzoek, waarbij de vraag wordt beantwoord: Verandert, en zo ja in welk opzicht en in welke mate, het 
zelfoordael van patienten bij ziekenhusopname betreffende de thuis ervaren gezondheid in thet algemeen en betreffende de stoelgang in het bijzonder?

Een samenvatterid hoofdstuk besluit deze studie.

Schematisch weergegeven, is dit proefschrift als volgt ingedeeld:

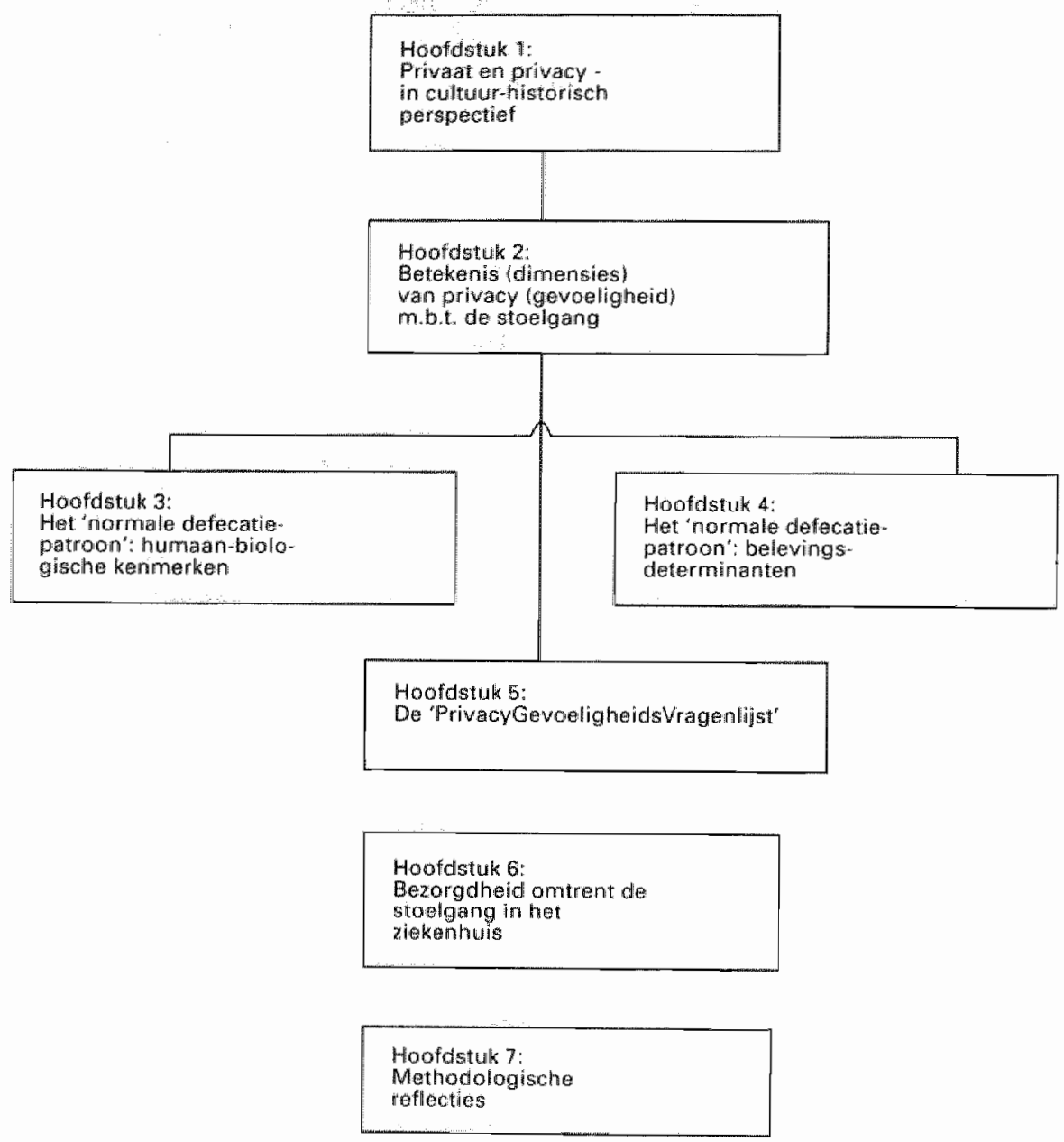

Sohema 0.1 Indeling van dit proefschrift 


\section{Privaat en privacy in cultuur-historisch perspectief}

\subsection{Inleiding}

Al van vóór het begin van de professionele verpleging (1859) heeft bescherming van privacy tot de taakstelling van de verpleegkundige behoord, zij het niet steeds onder deze benaming. In 1848 kritiseerde Meijer in zijn 'Handboek woor pleegzusters en zilekenoppassers" de 'praatzucht' van sommige werplegenden, in vergelijking waarmee hij de 'nieuwsgierigheid (als) een even hatelijke eigenschap' en "het gebrek aan geheimhouding (als) een nog grooter gebrek'karakteriseerde (Meijer, 1848). Florence Nightingale pleitte in 1859 , in haar klassiek geworden 'Notes on nursing: what it is and what it is not", woor de "vertrouwde verpleegster", op wie men staat kan maken. Ziji is (in de vertaling van mevrouw Busken Huet, 1862) "geene babbelaarster, geene praaljesmaakster"; zij praat niet over haar patiënten; zij "antwoordt niet op vragen ontrent hare zieken'. De 'vertrouwde verpleegster' dringt zich niet als een 'bemoeizieke gedienstige' op aan de patiënt die 'het liefst in de eenzaamheid' lijdt. Zij hindert de zieke niet met opdringerige "raadgevingen waarmede dergelijke zieken zoo overwloedig (kunnen) worden overstelpt." Raadgevingen zijn even 'onbescheiden en onwelvoeglijk' als vragen naar bijzonderheden omtrent "den ware toestand van den patiënt" (Nightingale 1859 , cf. Van Lieburg 1980).

Recentere generaties verpleegkundigen werden, aan de hand van leerboeken als die van Zuster Agathe (Zr. M. Agathe \& Kerckhoffs, 1969 ${ }^{16}$ ) of van Vun der Moolen en Quanjer $\left(1967^{4}\right)$, opgeleid met het respect voor de privacy van de patient (Spijker, 1979). Het beroepsgeheim wordt gevaloriseend. "Bed afschermen' en 'patient inlichten" werden mét "handen wassen" de traditionele trias van voorbereidende handelingen die elke leerling-werpleegkundige zich als automatisme behoorde eigen te maken.

Gevoelig wat privacy betreft blijkt men onder meer ten aanzien van de uitscheiding. Verpleegkundeboeken (Henderson 1978, Van der Peet 1984) bevelen discretie aan bij het helpen van patienten bij de stoelgang. Echter, de praktijk leent dat op de verpleegafdeling patiënten in verschillende mate gevoelig blijken voor privacy bij de defecatie. Lijken sommige patiënten datarbij door niets of door nienand gehinderd, anderen zijn daar uiterst gevoelig voor en ervaren bijwoorbeeld niet alleen iemands feitelijke 
aanwezigheid als een inbreuk op de privacy, maar zelfs een wc-bril die nog warm is vanwege het recente gebruik ervan door een medepatient (Bloemendal, Duijnstee, Hattunga Verschure, 1985).

Privacy blijkt bij een eerste conceptuele analyse en complex begrip, waarbij diverse onderzoekers (Westin 1967, Smith \& Swanson 1979, Wilmoth 1980) de wraag hebben gesteld of privacy in verschillende soorten zou bestaan, danwel of privacy een homoniem zou zijn voor verschijnselen wan unteenlopende aard. Immers, privacy kent uiteenlopende connotaties als feitelijke afzondering (cf. secretie, secreet), intimiteit, discretie, persoonlijke zelfontplooing, en ook autonomie en anonimiteit te midden van de menigte.

Wat Ariès in een van zijn bijdragen aan het vijfdelige werk over de geschiedenis van de persoonlijke levenssfeer stelt ten aanzien van het begrip en de aspecten van het persoonlijke leven, het privé-leven in zijn totaliteit, lijk t van toepassing op de gevoelens van privacy met betrekking tot de stoelgang in het bijzonder: privacy en de kenmerken ervan evolueren in de loop van de tijd (Ariès \& Duby, 1985).

Daarom is het relevant een blik te werpen op de geschieden is wan privacygevoelens en privacygedrag in het algemeen en die ten opzichte van de ontlasting in het bijzonder - en wel met speciale aandacht voor de gevoelens en uitingen van privacy in ziekenhuisomstandigheden in het algemeen en met betrekking tot de stoelgang aldaar in het bijzonder.

Over zowel de geschiedenis van het 'privaat' als van de persoonlijke levenssfeer bestaan geschreven bronnen. De 'Histoire de la merde' begint, volgens Laporte (1978), in 1539, wanneer de menselijke uitscheidingsprodukten een manifeste bedreiging blijken voor hygiëne en volksgezondheid. Sinds het koninklijk besluit, in dat jaar uitgevaardigd, blijven publikaties over het lozen en/of verwerken van excrementen elkaar opvolgen, hetgeen voorlopig culmineerde in de 19de eeuw, toen in Europa op grote schaal rioleringssystemen werden aangelegd (Laporte 1978, Gleichmann 1979, Corbin 1982, Roding 1986, Van Zon 1986, De Swaan 1989). Publikaties over hygiène, niet als collectieve maar als individuele zorg, vormen een tweede bron van geraadpleegde literatuur (Wright 1966, Palmer 1977, Vigarello 1985, Parent 1987, Csergo 1988). Een derde bron van informatie over de menselijke uitscheiding vormen middeleeuwse boerten en kluchten, met name teksten gebruikt met carnaval. Plejj (1979) spreekt in dit verband van een ware 'stront-folklore'; bij carnaval en andere volksfeesten in Europa blijft, ook in later eeuwen, de ontlasting een belangrijke rol spelen (Baroja 1965, Gaignebet 1979, Heers 1983) Over deze en soortgelijke teksten bogen zich de eerste, beschrijvende antropologen (Bourke, 1891) en later cultureel-antropologen en cultuur-en literatumistorici (Feldhaus 1921, Englisch 1928, Gaignebet 1980, Pleij 1988).

De geschiedenis van de persoonlijke levenssfeer werd, voor wat de Westeuropese samenleving betreft, geschreven onder redactie van Ariès en Duby $(1985-1987)$. Het nagenoeg ontbreken van onderzoek op dit gebied - Duby spreekt in zijn Préface van cen 'terrain tout đait vierge' - was aanleiding tot deze onderneming. Het standaardwerk dat door het schrijverscollectief tot stand is gebracht, kan op details worden aangevuld met deelonderzoek, zoals dat van Pardailhé-Galabrun, naar het ontstaan van het intieme (1988). 
Geschiedschrijving waarbij de historie van privaat en van privacygevoelens aan elkar worden gerelateerd, blijkt zeldzaam. Studies hieromtrent lijken beperkt tot het oeuvre van de socioloog Elias (1982). Aan de hand wan cultur-sociologische analyse van gedrags- en etiquetteboekjes postuleert deze een werschuiving in de loop van de tijd van het schaamte- en gênegevoel. Gedragingen waarvoor men zich in de ene periode niet schamame (of waaromtrent geen gêne ontstond wanneer men anderen die handelingen zag verrichten), begonnen in een volgende fase van het civilisatieproces als 'pijnlijk' voor het schaamte- en gênegevoel te worden ervaren.

Het civilisatieproces, aldus Elias, is een verandering van het menselijk gedrag en het menselijk leven in een bepaalde richting. Deze verandering is in de loop der eeuwen niet 'rationeel' door afzonderlijke mensen of groepen in de samenleving woltrokken. Maar evenmin is de verandering zonder orde. Een ordening van heel specifieke aard ontstaat uit de interdependentie van mensen. Deze onderlinge afhankelijkheid vormt met name het perspectief warin Elias het civitisatieproces bestudeert, bijyoorbeeld ten aanzien van verschuivingen in machtsposities in de klassen-en standenmaatschappij. Typerend voor dit proces is enerzijds de "rationalisering van het gedrag", anderzijds de modellering van de drifthuishouding door middel van "schaamte. en "gêne".

Gegevens omtrent 'privaat en privacy" worden dus niet aan primaire bromen maar aan secundaire bronnen ontleend. Hoewel deze laatste, overwegend bestaand uit onderzoeksverslagen, een grote mate van betrouwbaarheid moet worden toegekend, lijkt deze bronnenkeuze wellicht enigszins afbreuk te doen aan de gefundeerdheid van de hier ondernomen historische benadering. Deze echter pretendeert niet een historiografie te zijn in de vaktechnische betekenis van het woord. Immers, de pretentie zou onder meer een stellingname impliceren binnen de huidige geschiedwetenschappelijke situatie die door vakhistorici vrij unaniem als strikt pluriform wordt beoordeeld: pluriformiteit heerst zowel ten aanzien van de geschiedschrijving alsook van de geschiedtheorie (Tollenbeek, 1990). Binnen de veelheid van meningen en stellingnamen geldt in deze verslaglegging als algemene, tevens als fundamentele richtlijn hetgeen door Tollenbeek wordt geformuleerd als 'een brede consensus over een aantal stelregels, die kunnen worden samengevat in het gebod elke bewering in het geschiedverhal met redelijke en controleerbare argumenten te staven' (Tollenbeek, 1990). De hier geraadpleegde bronnen, hoewel secundair, leveren 'redelijke en controleerbare argumenten".

Gegevens omtrent 'priwaat en privacy" worden aan elkaar gerelateerd en geplaatst in een cultuur-historisch perspectief. Van primair belang daarbij is uiteindelijk kennisvermeerdering van de huidige beleving van privacy (door de patiënt) bij de stoelgang; wen stijl van geschiedbeoeffening die, vanwege de gerichtheid op het heden, door Tollenbeek "histoire-présent" wordt genoemd - in tegenstelling tot de "histoire-passé, waarbij de geschiedenis wordt beoefend ter vermeerdering van de kennis omtrent het verleden. Kenmerken van de "histoire-présent" zullen in deze verslaglegging kenbaar zijn: de nadruk op "het recurrente, het zich herhalende, het continue in het historisch proces" waarbij een en ander word geplaatst binnen de kaders zoals aanwezig in hel work wan Elias, Corbin, Ariès en Duby (de Franse Annales). Dat daarbij werd getracht valkuilen - als manifeste anachronismen, of finalistische interpretaties van het heden (Tollenbeek, 1990 ) - omzichtig te vermijden, moge blijken uit het wervolg. 
Het wan origine Angelsaksische woord 'privacy' is, aldus Kuitenbrouwer (1982), een rechtsterm die betrekking heeft op de 'persoonlijke levenssfeer'. Etymologisch is het terug te voeren op het Latijnse privare, dat betekent 'ontnemen, beroven, bestelen'. Het hiervan afgeleide privatus heeft een rechtskundige betekenis gekregen: "apart from the State, belonging to an individual' (Klein, 1971), 'withdrawn from public life, peculiar to oneself' (Onions, 1978).

De tegenstelling privatus en publicus wordt gebruikt in het klassieke Latijn. Cicero bijvoorbeeld kent de uitdrukking 'agere privatim' (tegenover 'publice'), hetgeen betekent handelen als particulier, privé-persoon, ter onderscheiding van handelen als ambtenaar/magistraat. Het gaat in dezen om gedrag thuis, afgezonderd van de anderen versus optreden in het openbaar, voor de ogen van iedereen op het forum.

Aan privatus zijn connotaties gebonden betreffende het familiale karakter van iets, of ook de alledaagse aard van gewone werkdagen. Ook duidt privatus op gedrag dat eigen is aan en vertrouwd binnen een bepaalde groep, bijvoorbeeld een kloostergemeenschap. De kloostermuur die de kloostergemeenschap afzondert van de buitenwereld (publicum) blijkt een belangrijke rol te spelen als omgrenzing van het slot (claustrum). Privatus betekent dan datgene dat of degene die teruggetrokken is, bijvoorbeeld het teruggetrokken leven in een klooster. Binnen deze gesloten gemeenschappen blijken weer aparte privatae te worden aangemerkt, gegeven het feit dat in het Latijn dat de moniniken schreven het woord privatae wordt gebruikt voor latrinae (Ariès \& Duby, 1985).

Evenals in de tijd der Grieken en Romeinen was het in middeleeuws West-Europa normaal dat men zich in het openbaar ontlastte. Waar, met name in wooncomplexen van enige omvang, een vertrek in het huis ten behoeve van de uitscheiding was gereserveerd, betrof het een garderobe of een zogeheten waarderebbe: een vertrek waar men zich met verschillende personen tegelijk ontlaste, maar dat tevens dienst deed als berging van bijvoorbeeld meubellen, kleding en woorwerpen.

De ontlasting, als proces en als produkt, alsook de plaats waar deze zich voltrok, kreeg in de middeleeuwse samenleving gaandeweg een 'privaat'-karakter, te oordelen naar de benamingen privy, privet, prevey, prevez, privaten, priveten, provate, profait, profeyen die men tegenkomt in allerhande teksten (van metselaarsrekeningen tot poẻzie) uit die tijd (Cabanès 1908, Feldhaus 1921, Wright 1966, Palmer 1977). Ook nu nog bestaat in het Nederlands het woord 'privaat' voor toilet/wc, zij het niet meer in de spreektaal als apart, zelfstandig naamwoord, maar alleen in samenstellingen als privatput ( $=$ beerput), privaattrechter en privaatton (Van Dale, 1984).

\subsection{Afzondering uit gemaksoverwegingen en/of uit schaamte}

In de tweedte helft van de 15 de eeuw blijkt een verschuiving op te treden in het stoelganggedrag: in grote lagen van de bevolking in West-Europa komt het 'huisje" in 
de plaats van hurken in het vrije veld. De overgang van het wrje yeld nar het aparte huisje wordt geillustreend door een houtsnede uit 1480 die een man toont dit zich ontast hurkend náást een "huisje", waarvan de deur uimodigend openstaat; de man verkiest (nog) de vrije natuur (Feldhaus, 1921).

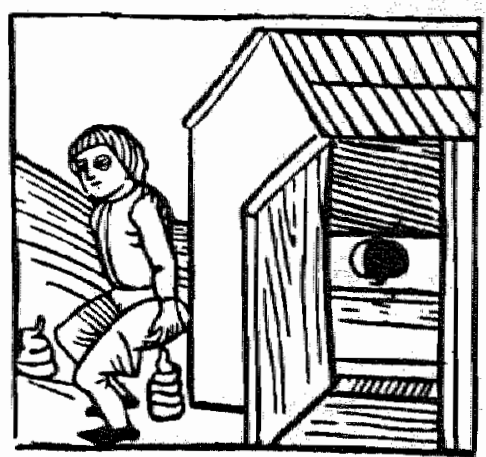

Aan het einde van de 15 de eeuw werd nog niet of althans niet sterk de behoefte gevoeld zich af te schermen uit schaamte of uit verlangen naar privacy in de huidige betekenis van het woord. Veeleer trok men zich terug uit overwegingen van gemak, door een dichter uit de 15de eeuw aldus verwoord (cit. Cabanes, 1908):

\footnotetext{
Retraict de grand commodité

Soit aux champs ou en la cilte;

Retraict auquiel personne n'entre,

Si ce n'esi pour purger son ventre;

Retraict de grande dignité.

oul le cul sied en majesté;

Retraict qu'on n'ose descouvrir,

Ny le dessus du siège ouvrir.

De peur, affin que je ne mente,

Que le fort parfum ne s'esvente:

Retraict oul'on se sent al lasse.

II vaut bien mieux que je me taise

Qu'empuantir de les senteurs

Le lecieur ell les auditeurs.
}

"Retraits et aisements", "heimlich Gemach" vindt men vanaf de $15 \mathrm{de}$ en vooral de $16 \mathrm{de}$ eeuw veelvuldig als aanduiding van het vertrek en de zitplaats (de 'gemak'-stoel) bestend woor de ontlasting (Cabanès 1908, Feldhaus 1921, Ariès \& Duby 1985).

In deze verschuiving in het stoelganggedrag past de uitvinding van het watercloset. In 1449 construeerde Thomas Brightfield in Londen een stenen wc met regenwaterspoeling. Het moet een ingenieuze constructie zijn geweest; de maker bleek echter zijn tijd ver vooruit: het voorbeeld vond pas anderhalve eeuw later navolging (Palmer, 1977).

Het duurde tot in het begin van de 16 de eeuw voor zich een meer algemene 
privatisering van toiletgedrag woltrok. Zo werd in 1513 in Parijs veroudend dat elke woning zijn 'huisje' moest hebben. In 1539 werd dienaangaande een belangrijk edict uilgevaardigd door Frans I, gevolgd door talrijke verordeningen van de plaatselijke overheid. In Engeland namen Hendrik VIII (1544) en Eduard VI (1549) maatregelen van gelike strekking (Feldhaus 1921, Palmer 1977, Laporte 1978).

Dergelijke verordeningen zijn niet alleen belangrijk uht hygiẻnisch oogpunt, namelijk als maatregelen ter bevordering van orde en reinheid in een samenleving die steeds meer als verontreinigd, besmettelijk en ziekteverwekkend werd ervaren. Zij zijn eveneens van betekenis als aanwijzing woor het verdwijnen van de ontlasting uit het openbare leven. De stoelgang wordt een privé-aangelegenheid, iets dat in afzondering, 'withdrawn from public life', dient te geschieden.

\subsection{Verschuiving van de schaamtegrens}

Geheel in overeenstemming met het bovenstaande is het verschijnen in deze zelfde tijd, namelijk in 1530, van Erasmus' bekende 'De civilitate morum puerilium' - bekend tot op heden toe onder meer door de cultuursociologische anallyse door Elias (1982) van dit soort gedrags- en etiquetteboekjes. In dit wellevendheidsboekje behandelt Erasmus een aantal menselijke verrichtingen, waaronder die met betrekking tot de uitscheiding. Naar hedendaagse smaak spreekt Erasmus daarin wel erg openhartig over zaken die tegenwoordig niet of in bedekte termen worden aangeroerd. Toch was het zijn bedoeling bij de lezers juist schaamte en gêne op te wekken. Zijn boekje betekent een aanzienlijk oprukken van de schaamtegrens. Wel was het in vele opzichten een regelrechte voortzetting van de middeleeuwse traditie wat betreft onbevangenheid. Zo geeft Erasmus wat betreft het laten van winden aan dat het voor de gezondheid beter is een wind met lawaai te laten dan hem te onderdrukken of op te houden. Maar tegelijkertijd kondigt zich op onmiskenbare wijze iets nieuws aan: het verschijnen van dit boekje markeert het ontstaan van een savoir-vivre, een gedrag als uiting van beschaving, een wellevendheid (civilité) die hoffelijkheid (courtoisie) als etiquette-ideaal, representatief voor de ridderlijk-feodale hoofsheid, gaandeweg naar de achtergrond verdrong. In de 16 de eeuw raakt deze hoffelijkheid bij de bovenlaag in onbruik, terwijl het wellevendheidsideaal toeneemt en in de $17 \mathrm{de}$ eeuw, althans in Frankrijk, tenslotte de overhand krijgt. Deze verschuiving is aanwijsbaar in gedragsveranderingen (Elias, 1982).

Een volgende fase in de verschuiving van de schaamtegrens wordt gemarkeerd door het etiquetteboek 'Gatlateo' van Giovanni della Casa (1558). Uit dit werk blijkt, volgens Elias, hoe bij menselijke verrichtingen als de stoelgang de positieve lustcomponenten steeds sterker sociaal onderdrukt worden in samenhang met toenemende angst. Nauwkeuriger gezegd: de positieve lustcomponenten werden 'geprivatiseerd', voorbehouden voor de binnenwereld van het individu, voor de sfeer van de heimelijkheid, terwijl de negatief geladen affecten als onlust, afschuw en 'pijnlijkheid' in stand werden gehouden, zo niet versterkt.

Uit hetzelfde jaar waarin Sir John Harington zijn revolutionaire toilet met waterspoeling uitvond, namelijk \589, dateert de 'Braunschweigische Hofordnung' met daarin 
het verbod zich te ontlasten op de wenteltrappen, op andere trappen, in gangen en vertrekken.

Met de ontlasting wordt het gehele gedrag betreffende de stoelgang hoe langer hoe meer uit de openbaarheid verdreven en geisoleerd in de 'kleinste kamer'. In 1619 stelt Weste in zijn 'Booke of Demeanor and the Allowance and Disallowance of certaine Misdemeanors in Companie', dat hoorbaar een wind laten in verlegenheid brengt. De wind wordt verwezen nar de schelmenroman: in 1651 verschijnt de 'Roman Comique" van Scarron. Ook op de flatus komt een taboe te nusten, slechts doorbroken bij carnaval: "La défence du pet; pour le Galant du carnaval" (1652, cit. Englisch. 1928):

Si pour en pet fail par hasard,
Votre coeur, ou jail tant de part,
Pour jamais de moi se retire,
Voutez-vous que Dorenavant
Vous me donniez sujet de dire
Que vous changez au moindre vent?

Wanneer de overheid via verordeningen dan wel de wellevendheidsboekjes via etiquettevoorschriften dwingende eisen stellen, betekent dit vaak dat de maatschappelijke realiteit nog afwijkt van het beoogde ideaal. Uit de correspondentie van de hertogin van Orlëans blijkt dat rond 1694 Parijzenaars zich nog in de straten van de stad ontlastten. Overigens ziet zij zichzelf daartoe ook gedwongen. Op 9 oktober 1694 schrijft de hertogin vanuit Fontainebleau aan de keurvorstin van Hannover:

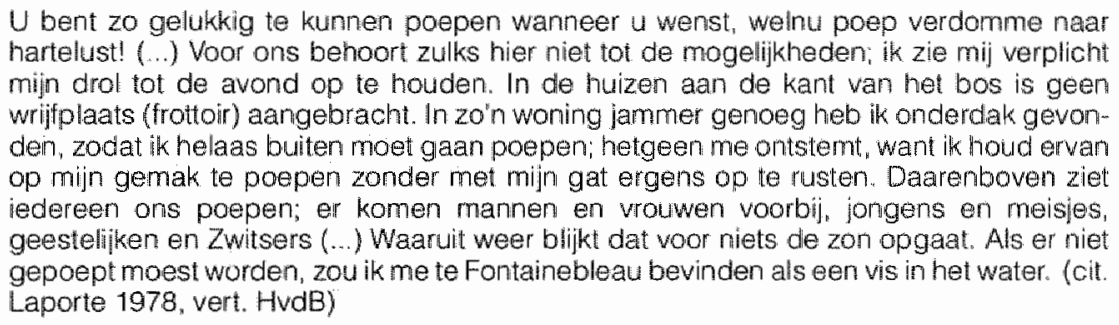

Deze brief is opmerkelijk. De Palentijnse prinses beschikt niat over een privaat. Voor hwar ontlasting moet zij naar buiten, en dat is nogal ongemakkelijk. Maar niet alleen mist zij node de 'retraict où l'on se sent à l'aise', maan "daarenboven ziet ledereen ons poepen'. Ontlastend zien en gezien worden blijken dus nu, althans woor has en voor degene met wie zij correspondeerde, gebonden aan gevoelens van gêne en schămte.

Nog rond 1700 ontlast de Zonnekoning zich ten overstaan van zijn hovelingen (Cabanès 1908, Feldhaus 1921). Aldus doet ook de hoge adel. Rond 1710 doet de Grand Dauphin nog hetzelfde, maar tijdens her gesprek wendt men hem discreet de rug toe. In 1729 benadrukt La Salle in 'Les Règles de la Bienséance et de la Civilité Chrétienne' de ondubbelzinnige eis alle natuurlijke verrichtingen aan andermans oog te ontrekken. $\mathrm{Bij}$ een volgende uitgave van dit boek in 1774 blijken gedetailleerde beschrijvingen van de natuurlijke verrichtingen uit de desbetreffende passages geheel verdwenen. Rond deze zelfde tijd is sprake van een ware revolutie, met name in Engeland, in de toilettechniek, waardoor de feitelijke isolatie van de ontlasting en de daarmee werband 
houdende reuken geperfectioneerd werd: Clive (1770-74), Cumming (1775), Prosser (1777), Bramah (1778), Law (1796) (cf. Palmer, 1977).

De 18 de eeuw is, wat sanitaire behoeften betreft, de eeuw van de bedekte temen en eufemismes. Men sprak van 'een zekere behoefte", waaraan men voldeed op 'een zekere plats". Men ging, wanneer men tot het personeel behoorde, de tuin in "om een roosje te plukken"; of men maakte, als men tot de gegoeden behoorde, gebruik wan de gemakstoel, die in de tweede helft van deze eeuw onzichtbaar werd ingebouwd in modieus slaapkamermeubilair, de 'conveniences'. Voor 'chaise percée' ontstonden er verhullende synoniemen als chaise d'affaires, chaire pertuisée, chayère de retrait, chaise de propreté, chaise nécessaire, of eenvoudigweg 'selles". Havards 'Dictionnaire

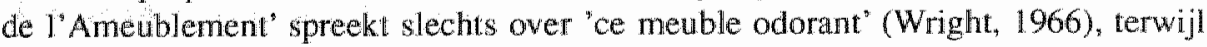
Parijse notarissen in boedelbeschrijvingen dleze objecten als 'ne méritant pas estimation" vaak over het hoofd zagen (Pardailhé-Galabrun, 1988).

\subsection{Een 'nieuwe intimiteit'}

In de laatste decennia wan de 18 de euw werden de nieuwe vindingen op sanitair gebied zoals hierboven genoemd, geintroduceerd in de overige landen van West-Europa. In het paleis var Versailles werden rondom 1770 'water-closets à l'Anglaise" geinstalleerd. Lodewijk XVI en Marie-Antoinette waren aldus de eersten en de enigen die "een nieuwe intimiteul" genoten; het woortschrijdende proces wan privatisering van de ontlasting begon de stoelgang te maken tot 'monologue intérieur' (Corbin, 1982). Dit proces van privatisering viel samen met het begin van de strijd tegen de starik. Niet alleen in ziekenhuizen werden stank en rottende lucht bestreden, ook het graf werd geprivatiseerd. Nadat in 1780 voor het eerst eenpersoons ziekenhuisbedden werden voorgeschreven (Corbin, 1982), werden tegen het einde van de 18 de eeuw ook graftomben geprivatiseerd, dus bestemd voor én persoon. In de middeleeuwen immers was het in de ziekenhuizen de gewoonte geweest verschillende zieken hetzelfde bed te laten delen. Alleen voor ernstig zieken gold, zoals in het Parijse Hôtel-Dieu, het voorschrift dat, voor zover mogelijk 'les griefz malades chascun a part soy en ung lit" (Ariès \& Duby, 1985).

Voldoen an de natuurlijke behoeften zal doorgaans veel ongerief hebben veroorzaakt. In sommige gasthuizen aan kloosters verbonden was men van enig gemak voorzien. Het gastenverblijf in de abdij van Cluny telde evenveel latrinae als bedden (Cabanes, 1908). In het Hospitaal te Millan werden in 1464 door de beroemde bouwmeester Pietro Averlino Fillarete bijzondere toiletten aangebracht: tussen iedere twee bedden leidde een kleine deur naar een gewelfde nis mel zitplaatsen voor de stoelgang, afwatering via open water en luchtverversing via gemetselde kokers (Feldhaus, 1921 ).

Maar de gang van zaken rond de ontlasting werd in vele ziekenhuizen als weinig bevorderlijk voor de gezondheid ervaren. De chirurg Tenon, die in het hierboven genoemde Hôtel-Dieu op koninklijk bevel een onderzoek omtrent de hygienische omstandigheden vernichtte, rapporteerde in zijn "Mémoires sur les hôpitaux de Paris' (1788): 
De inhowd van de beddepannen werd dageliks op de ziekenzalen overgegoten ingrotere vaten. Daardoor, alsook vamwege de fecallen die op de vloer vielen, was de lucht in die vertrekken infect.

De strozakken die verzadigd waren van de urine en excrementen wan de zieken, werden om vier uur 's morgens geopend en de inhoud over de voer uigespreid. Gelijttijdig werden ook de wullingen van de andere matrassen geledigd. In plaats van de bevilide inhoud ter plekke te verbranden, voerde men hei stro per kar naar het hospilaal Saint-Louis. De muren zijn bedekt met excreta, de vloer met fecalièn die uil de strozakken lekken of bij het ledgen van de beddepannen gemorst worden. De lucht op de ziekenzalen is dienovereerikomstig. (cit. Feldhaus 1921. vert. HvaB)

In de laatste decennia van de 18 de eeuw ging men dan ook strategieën ontwikkelen om de samenleving te 'ontwalmen': 'les stratégies de la désodorisation de l'espace publique' (Corbin, 1982). Uiteenhalen en verspreiden wan té dicht op elkaar levende mensen was een van die strategieën, die zich met name concentreerde op het individuele bed.

Het eigen, persoonlijke bed betekende mede het einde van het delen van elkaars uitwasemingen en lichaamsgeuren. De voortgaande privatisering zou, in de $19 \mathrm{de}$ eeuw, leiden tot de eigen, privé-slaapkamer.

De ziekenhuizen blijken bij het vaststellen van de nieuwe hygiënische normen een trendsettende rol te hebben gespeeld. Daar immers begon het individuele bed als persoonlijk territorium. Het Hôtel-Dieu te Lyon schreef, aldus Corbin (1982) in 1780 als eerste ziekenhuis het individuele ziekenhuisbed voor. Dertien jaar later werd dit voorschrift door de Conventie dwingend opgelegd, als logische toepassing van de Déclaration des droits de l'homme et du citoyen (1789): een associatie met mensenrechten die ons heden ten dage op zijn minst verbaast.

\subsection{Begrenzing van privacygevoeligheid}

Het proces van privatisering niet alleen van het bed maar ook van de ontlasting, versneld ten tijde van de Franse Revolutie, treedt in de 19de eeuw in een fase van relatieve consolidering. Gevoeligheidsgrenzen worden gaandeweg daar gellegd waar onze huidige maatschappij deze nog steeds onderkent en erkent. De ontwikkeling en toepassing van gedragsregels of -verwachtingen met betrekking tot de witscheiding, in voorafgaande perioden begonnen in de hoogste klassen van de matschappij, zetten zich voort tot in bredere lagen van de bevolking.

Een semi-privatisering vindt plaats in de grote Parijse woonhuizen, waar families met de huisdeur op dezelfde overloop van een en hetzelfde toilet gebruik gingen maken. Gaandeweg wordt de stoelgang nu zozeer privé-aangelegenheid, dat per familie, per gezin de uitscheiding steeds meer plaats vindt op het eigen 'privatat'. Rond het midden van de 19 de eeuw worden op grote schaal in woonhuizen nieuwe toiletten aangebracht, eerst bij de bourgeoisie, vervolgens ook in de arbeiderswijken. De snelle ontwikkeling van de privacy in alle bevolkingslagen verloopt hand in hand met de bescherming die men zoekt tegen thet vuil en de stank van de anderen, 'à réussir une familiarisation approximative de la merde' (Corbin, 1982).

Tijdens de laatste decennia van de 19 de eeuw worden openbare toiletten van schotten voorzien ('Schamwände', Gleichmann 1979), eerst de zit-wc's, vervolgens ook de 
urinoirs. De mens, of althans de betreffende organen, worden bij de uitscheiding aan het oog ontrokken. Tezelfdertijd wordt het onderscheid en de scheiding tussen mannenen vrouwentohethen, ingevoerd sinds 1739 (Wright, 1966), verder doorgevoerd, tot en met aanpassing van het sanitair aan de mannelijke en vrouwelujke anatomie (Gleichmann, 1979).

Het terugdringen van de ontlasting wit de openbaaheid naar de private sfeer verloopt parallel aan de privatisering van het lichaam met zijn uitscheiding van stoffen en geuren. Vanaf de tweede helft van de 19 de eew worden individuele kamers, met name slaapkamers, steeds neer gebruikelijk. Deze privatisering door middel van het persoonlijke ventrek kreeg hoge prionteit onder de kleine burgerij (devient une exigence commune au sein de la petite bourgeoisie") in een tijd dat in de ziekenhuizen het individuele bed nog lang niet overal was ingevoerd (Corbin, 1982).

Een belangrijke stap voorwaarts op sanitair gebied betrof tegen het einde van de $19 \mathrm{de}$ eeuw de ontwikkeling van spoelsystemen en andere technieken om de fecale materie te isoleren en reukloos af te voeren. Na een latentieperiode wan bijna twee eeuwen sinds de uitvinding door Sir John Harington van de eerste we, dat wil zeggen toilet met waterspoeling, volgen nu diverse varianten daarvan elkaar opvallend snel op: de Aerth Closet van Henry Moule (1860), de Optimus Improved Valve Closet van Heyller (1870), J.R. Mann's Syphonic Closet (1870), Jenning's Pedestal Vase (1884), het vlakspoeltoilet Unitas van Twyford (1885), en de diepspoeler van D.T. Bostel (1889) (cf. Wright 1966, Roding 1986, Parent 1987).

In de eerste helft van de 20 ste eeuw zet zich het privatiseringsproces voort gezien de wijze van herindeling en herschikking van woon- en leefruimten, zowel binnen-als buitenshuis. Hoewel niet in alle lagen van de bevolking in gelijke mate en gelijk tempo, noch ten aanzien van dezelfde aspecten van het menselijk leven of dezelfde verrichtingen, wordt privacygevoeligheid steeds meer maatgevend voor de inrichting van het leefmilieu. In arbeiderswijken blijft de gemeenschappelijke wo op bimmenplaats of overloop het langst in gebruik. Zo blijken in Frankrijk vele toiletten waarvan verschillende gezinnen zich bedienen tot na de Tweede Wereldoorlog in functie. Dit overigens gaandeweg meer als uitzondering dan als regel, gezien het feit dat in 1973 nog $70 \%$, in 1982 reeds $85 \%$ van de gezimnen een eigen toilet binnenshuis gebruikt (Ariès \& Duby, 1987). In de huidige nieuwbouw wan eengezinswoningen lijkt éen toilet per verdieping de norm.

In de voortgang in de sanitaire techniek is een afspiegeling te zien van de voortschrij ding van de privatisering van de stoelgang. In de jaren tussen de wereldoorlogen wordt geprobeerd de wo zo geruisloos mogelijk te maken door een goede isolatie van de wanden en door afschaffing van de hooggeplaatste stortbak. Hinderlike geluiden, die onaangename associaties konden oproepen werden zo tegengegaan. In de bouwvoorschriften van overheidswege werd het om hygiënische redenen verboden badkamer of toilet rechtsureeks vanuit woonruimte of keuken toegankelijk te maken (Roding, 1986).

De herschikking van leefruimten gaat niet ongemerkt aan het ziekenhuis voorbij. Nadat in de loop van de 19 de eeuw het gemeenschappelijke ziekenhuisbed heeft plaatsgemaakt voor het individuele, blijkt in de tweede helft van de 20 ste eeuw de gemeenschappelijke ziekenzaal 'onverdraagbaar en wreed, alleen nog goed voor daklozen': 'elle constitue pour nos contemporains, habitués à avoir leur propre chambre 
et qu'angoisse la maladie, une sorte d'archäsme barbane et inhumain' (Prost, in: Aries \& Duby, 1987).

De grote ziekenzalen van de oudere ziekenhuizen worden dan ook sinds enkele decennia omgebouwd tot verpleegafdelingen met kamers voor enkele personen, met eigen toiletaccommodatie. Deze meer persoonlijke ziekenkamers herbergen patiènten bij wie een civilisatieproces van eeuwen niet alleen hun leefpatroon heet gemodelleerd, maar ook het toiletgedrag. De naoorlogse tendens van toilet-en badkamervermenig. vuldiging in de woningbouw zet ook in de ziekenhuisbouw steeds verder door. Het lijkt er bijna op dat het beddescherm op de ziekenzaal vervangen raakt door de deur en muir van de ziekenkamer.

\subsection{Discussie en samenvatting}

1.7.1 De privacy van de patiènt, terecht gevaloriseend door de verpleegkundige professie, is als resultante te zien van een eeuwenlang civilisatieproces.

Een van de exponenten van dit civilisatieproces vormt de terugdringing van de stoelgang vanuit het openbare leven naar de privésfeer. De stoelgang is geworden tot een strikte privémaangelegenheid; het haakje op de wc of het draaiende schijfje met de woorden 'belet' of 'bezet' zijn in dit verband illustratief.

In dit beschavingsproces zijn bepaalde gebeurtenissen en voorvallen aan te merken als tussentijdse markeringen van bepaalde perioden. Ten aanzien van de ontlasting blijken deze markeringspunten aanwijsbaar met behulp van incidenten zoals de verschijning van wellevendheidsvoorschriften en wettelijke verordeningen. Parallel daarmee loopt de ontwikkeling wan de sanitaire techniek. Wie de geschiedenis van etiquerte, van wet- en regelgeving, allsook van de sanitaire techniek overziet, zal opmerken dat het civilisatieproces ten aanzien van de stoelgang een eenduidige richting vertoont, parallel aan Elias" beschrijving van het civilisatieproces in zijn totaliteit.

Hoewel eenduidig van richting, vertoont het privatiseringsproces rond de stoelgang differentiatie in tempo naar plaats en sociale klasse. Deze ontwikkeling heeft niet overal in Europa hetzelfde tempo gevolgd. Aspecten van stoelganggedrag die in een bepaaide periode in bepalalde landen (nog) acceptabel zijn, blijken elders (reeds) over de sociale 'pijnlijkheidsgrens', in de betekenis zoals gebruikt door Elias, te garn.

Vervolgens blijken gedragsregels evenals de "pijnlijkheidgrens" waarvan do regels getuigen - progressief van kracht bimnen de verschillende lagen van de bevolking, te beginnen bij de bovenste lagen, de leidende klassen, en vervolgens afdalend tot de onderste lagen van de matschappij. Hoewel al in 1710 de kroonprins van Frankrijk de rug wordt toegewend als deze zich tijdens het gesprek ontlast, en in 1729 een invloedrijk etiquetteboek voorschrijft de stoelgang aan thet oog te onttrekken, hebben tegen het einde van die eeuw de gewone Parijzenaars nog de gewoonte openlijk te defeceren in de straten van de stad en in de lanen rond het paleis van Versailles.

Tenslotte lijkt behalve ten aanzien van de ontlasting, enige verscheidenhe id zichtbar in het civilisatieproces met betrekking tot een aantal andere menselijke verrichtingen. Privatisering heeft plaatsgevonden niet alleen van de uitscheiding, maar ook - in relatie daarmee, zoals uit het bovenstaande blijkt - van bedgedrag, zowel ten aanzien van hel 
genieten van nachrust als van erotiek en seksualiteit, en wan het menselijke (mannelijke maar vooral vrouwelijke) naakte licham, alsmede van lichamelijke hygiene.

Pijnlijkheidsgrenzein werden dus getrokken ten aanzien van de stoelgang. De civilisatietheorie wan Elias (1982), beschreven aan de hand wan samenlevingsaspecten zoals geweldsmonopolisering, staatsvorming en menselijke verrichtingen als eten, spuwen, neus sruiten, is ook op de privatisering rond de stoelgang toepasbaar.

Gedragsveranderingen ten aanzien van de stoelgang worden door Ellas (1982) beschreven als het steeds verder oprukken van schaamtegrens of pijnijkheidsdrempel, een proces van toenemende beheersing van impulsen, wan beteugeling van primaire hartstochten, van steeds meer remmingen met betrekking tot spontane driftuitingen. Als verklaring van dit hele proces wijst Elias in de eerste plats naar het proces van staatsvorming en geweldsmonopolisering dat zich tijdens de middeleewwen in WestEuropa voltrok. In de loop van dit proces, en ongetwijfeld onder invloed ervan, onderging de levenswijze van de adel veranderingen. Hovelingen waren meer en meer van elkaar afhankelijk; levensvoorwarde bleek het vermogen agressieve impulsen te beheersen, althans ze niet wia fysiek geweld te uiten. Geweld als individuele machtsbasis werd steeds meer vervangen door goede manieren (cf. de etiquetteliteraturu) en een overwicht door middel van beschaving.

Naast deze veranderende leefwijze noemt Elias de toenemende distinctiezucht van de adel, evenals een zekere 'democratisering' van de samenleving sinds de Franse Revolutie, in de 19 de en 20 ste eeuw. Deze laatste factor bevorderde een verregaande verbreiding van het civilisatieproces over grote groepen in de samenleving, evenals een sterkere integratie van de beschavingsnormen in de persoonlijkheid.

1.7.2 Diverse histonici, van Robert Favre tot Jacques Guilleme en van Michel Foucault tot Bruno Fortier, aldus Corbin (1982), zijn het erover eens dat het ziekenhuis een bepalende rol ('le rôle déterminant') heeft gespeeld in het tot stand komen van de nieuwe normen, met name wat betreft privatisering van de basisbehoeften. In het ziekenhuin krijgt het individuele bed, eenmaal ingevoerd in Frankrijk als logische toepassing van de Rechten van de Mens en van de Burger (1793), betekenis als individueel territorium. De revolutionaire rol van het ziekenhuis blijkt overigens beperkt: het aparte toilet per ziekenkamer werd op verpleegafdelingen niet openigszins uitgebreide schaal ingevoerd vór het midden van de 20 ste eeuw, lang dus nadat in de Westeuropese samenleving het individuele gezin kon beschikken over de eigen wc.

In her ziekenhuis is de verschuiving van de schaamtegrens herkenbaar, waarbij dus soms een voorsprong, soms een achterstand op het leven buiten de ziekenhuismuren zichtbaar wordt. Is het ziekenhuis daarmee een plaats waar "pijnlijkheidsdrempels" ver, zo niet het verst kunnen worden opgetrokken? $\mathrm{Zo}$ ja, bestaan er gronden waarop verwachtingen met betrekking tot de toekomst geformuleerd kunnen worden?

Enerijds staat de verpleegafdeling bekend als de plaats waar publieke conventies an kracht verliezen, soms zelfs geheel of gedeeltelijk overboord worden gezet. De patiènt, geconfronteerd met vaak wezenlijke vragen die worden opgeroepen door existentiele angsten en/of levensbedreigende situaties, zal snel geneigd zijn af te zien van als overbodig ervaren wellevendheidswoorschriften.

Anderzijds bligkt uit literatuur en theoretisch onderzoek, dat ziekzijn een situatie is 
warin de mens bij uitstek geisoleerd en vervreemd kan raken (Bremer, 1972). Ziekte vereenzaamt (Van der Bruggen, 1976, 1987). De zieke mens zal, teruggeworpen op zichzelf, zich wellicht juist vastklampen aan de omgeving, de samenleving met zijn verwachtingen ten aanzien van het ziekzijn als bestaanswijze: verwachtingen wammee gedragsregels verbonden zijn.

Met andere woorden: er zijn zowel redenen om aan to nemen dat in het ziekentuis de 'pijnlijkheidsdrempel' voor patiènten ten opzichte wan de stoelgang lager zal zijn, evenals redenen om te veronderstellen dat deze hoger zal zijn dan in de nomale siltuatie thus. Beantwoording van de v raag naar het hoe, waar en walrom van deze differemtiatie behoeft nader onderzoek.

1.7.3 Privacy in de huidige betekenis van persoonlijke levenssfeer gaat terug tot de negentiende eeuw, toen menselijke verrichtingen als de stoelgang voor grote delen van de bevolking helemaal tot de persoonlijke levenssfeer zijn gaan behoren. Pas in het midden van de twintigste eeuw is het begrip praktisch relevant gebleken, namelijk op het gebied van architectuur en rumtelijke ordening, samenlevings- en samenwerkingsvormen en informatica.

Langs de boven gegeven historische lijnen blijken de grenzen aan wat than prikacy heet in de loop der tijden van aard en bereik te veranderen. Ten aanzien van de inhoud van het begrip privacy zijn op face-value een aantal aspecten te onderkennen. Het begrip privacy heeft connotaties als privé, particulier, persoonlijk. Het roept associaties op met teruggetrokken, ongehinderd alleen, niet toegankelijk voor vreemden, eigen, behorende tot mijzelf: privacy in de betekenis van persoonlijke levenssfeer. Het is de levenssfeer waarin intieme handelingen worden verricht, ideeën en wensen worden gekoesterd, herinneringen worden bewaard - allemaal dingen waartoe onbevoegden geen toegang hebben.

Privacy appelleert aan een teruggetrokken, veilige plaats. Maar evenzeer houdt het intimiteit in: teruggetrokken zijn in zichzelf.

Privacy heeft ook een juridische, (privaat) rechtelijke betekenis: recht op een eigen, persoonlijk terrein, het recht om alleen te zijn, om met rust gelaten te worden, om de beschikking te hebben en te houden over de gegevens betreffende de eigen persoon. Kortom: recht op privacy.

Ook bescherming kan worden aangemerkt als een element wan het begrippenkader van privacy. Deze bescherming kan zowel van materiele als van immateriele aard zijn, namelijk 'als door een onzichtbare muur', zoals Elias de scheidswand noent warmee de moderne mens gescheiden is van de medemens ten opzichte van wie hij zich steeds minder overgeeft aan primaire opwellingen en spontane gevoelsuitingen.

Waar sprake is van bescherming, is er eveneens sprake van druk, agressie, dwang. Dwang bleek gelegen in verwachtingen van de medemens, waaraan men verondersteld wordt te voldoen op straffe van afkeuring, onderwaardering, vernedering en wel op straffe van een pijnlijke situatie, waarin men met zijn figur" geen raad weet, door de. grond zou willen zakken, van schaamte. Of van gène, als plaatsvervangende schaamte. 


\section{Privacy: begripsverheldering en consequenties voor de patiënt}

\subsection{Inleiding}

Privacy, in de verpleegkunde sinds lange tijd gevaloriseerd, wordt, maatschappelijk gezien, vanaf 1970 in toenemende mate onderwerp van gesprek: "Vóor 1970 wordt (in Nederland, HvdB) slechts sporadisch het begrip privacy genoemd en als het al gebeurt, dan is het onder verwijzing naar de situatie in de Verenigde Staten. In 1970 verandert dit beeld' (Holvast, 1986).

Opmerkelijk echter is dat patiënten, verplegenden en verzorgenden, en ziekenhuisbestuurders die privacy aan de orde stellen, elkaar daarover nauwelijks bijken te verstaan. Enerzijds zijn talrijke klachten over gebrek aan privacy van patiënten bekend uit (auto)biografisch werk van (ex-)patiënten en hun naaststaanden. Anderzijds blijken privacyregelingen, die momenteel op aanzienlijke schaal in ziekenhuizen worden geintroduceerd, niet de beoogde belangstelling van de patiënten te wekken: "Het is jammer dat er van de zijde van de patiènt zelf weinig belangstelling voor privacy is. Het is moeilijk om in een organisatie een goede inkleuring van privacybescherming te geven zonder dat de belanghebbenden daar regelmatig naar vragen" (Hildrink, 1986).

Wat door Holvast, in navolging van De Graaf (1977), wordt vastgesteld met betrekking tot privacy in het algemeen, blijkt in het bijzonder te gelden voor privacy in de gezondheidszorg: 'Noch uit het overzicht van de ontwikkeling in de Verenigde Staten, noch uit de situatie in Nederland wordt duidelijk wat onder het begrip privacy moet worden verstaan en wat nu precies die aantasting van privacy inhoudt' (Holvast, 1986).

Verheldering van het begrip privacy is de doelstelling van het deelonderzoek waarover in dit hoofdstuk wordt gerapporteerd. Conceptverheldering, dit wil zeggen de nauwkeurige omschrijving van de betekenis van woorden, die binnen een discipline i.c. de verpleegkunde - een valak impliciete, stilzwijgend geaccepteerde, en veelal diffuse betekenis hebben, staat de laatste decennia in het middelpunt van de verplegingswetenschappelijke belangstelling. Zowel in de directe verpleegkundige zorgverlening als in verpleegkundig wetenschappelijk onderzoek en het verpleegkunde-onderwijs alsook in het verpleegkundig management, voelen beroepsbeoefenaars behoefte aan een eenduidig en voor operationalisering geschikt begrippenkader (Norris 1982 , Walker \& Avant 1988).

Sinds de studies in het midden van de jaren vijftig over anxiety (Gregg, 1952), loneliness (Peplau, 1955), reassurance (Gregg, 1955), en andere in de verpleegkuncle veel gebruikte begrippen zoals nausea and vomiting, thirst phenomenon and fluid 
restriction, insomnia, tiredness and fatiguie (cf. Norris, 1982), heeft conceptverheldering in de verplegingswetenschap zich ontwikkeld tot een beproefde strategie, met behulp warvan wezenlijke karakteristieken van een bepaald concept worden geformuleerd en betekenisdimensies van het begrip worden vastgesteld. De strategie bestaat in de analyse van het gebruik van het gekozen woord zowel binnen als buiten de context van de eigen vakliteratuur (Walker \& Avant, 1988). De literatuur met behulp waarvan werd getracht het concept privacy te verhelderen, werd enerzijds werkregen met behulp van computersearch aan de hand van het trefwoord "privacy" in de medische en gedragswetenschappelijke vakliteratuur; anderzijds werden egodocumenten uit vakliteratuur en bellettrie bij de begripsverheldering betrokken.

\subsection{Privacy: een poging tot een begripsomschrijving}

\subsubsection{Afzondering en middelen daartoe}

Een feitelijke, zeg een materiële afzondering blijkt een van de aspecten die in verband met privacy genoemd worden. Het woordenboek omschrijft privacy als 'gelegenheid om zich af te zonderen om storende invloeden van de buitenwereld te ontgaan' (Van Dale, 1984). De Oxford Dictionary (1978) noemt in dit verband seclusion, hetgeen afzondering, uitsluiting, eenzame plaats betekent. Het haakje op de wc-deur is een eenvoudig voorbeeld van beveiliging, zekerstelling van deze afzondering. Een patiënt in bed of op de po-stoel naar een apart vertrek rijden voor een ongestoorde stoelgang, behoort tot de maatregelen die de verpleegkundige kan nemen ter bescherming van iemands privacy.

Afzondering terwille van privacy wordt overigens niet alleen bereikt door middel van lokale isolatie. Privacy kan men genieten door een toestand van teruggetrokkenheid te creëren ('the state or condition of being withdrawn', ibid.), zelfs te midden van een mensenmassa. Men heeft zich dan als het ware in zichzelf of in anonimiteit teruggetrokken; verhulling van persoonlijke identiteit is een middel ter behoud van privacy.

Dit laatste overigens geldt slechts binnen bepaalde grenzen: midden tussen de mensen doet of laat men sommige dingen niet of juist wel, ook al voelt men zich geenszins bedreigd in zijn persoonlijke levenssfeer. Het menselijke gedrag wordt, ook in dergelijke situaties, bepaald door gewoonten, door stilzwijgende afspraken, door normen.

$\mathrm{Zo}$ is het gebruikelijk dat men andermans brieven niet leest. Geopende brieven laat men ongemoeid. Dank zij normen in de samenleving geniet persoonlijke correspondentie een hoge mate van privacy (cf, briefgeheim).

Eveneens gaat men een persoonlijk vertrek niet binnen zonder kloppen. Ontstaat er een situatie waarin 'kloppen fungeert als aankondiging van "Uit de weg. Daar kom ik aan", dan wordt dit als een inbreuk op de privacy beschouwd:

Zells in zeer kleine hotels is meer privacy dan in het verpleeghus waar ik zh. En dan bedoel ik nog niet eens dat de deur ieder ogenblik open gedaan kan worden door een verpleegster die de post gaat controleren: "Heeft u een brief uit San Francisco gekregen? Wai leuk. Heeft u kennissen in San Francisco?"

Kibppen betekent "Uit de weg. Daar kom ik aan". 
's Zaterdagsmorgens ga ik in het bad. In de late uren des zaterdagsmorgens is de hans dus groot, mil in onkiede toestand aan te treffen. Een jaar geleden gebeurde dat een nieuwe verpleegster. Zl wou gaan gillen, de aanstelster, maar bebacht nog net op tijd da: je zuster bent of niet, en woeg toen of ik suiker in mijn yoghury wilde. Ik vond dat keurig: (U.H. Donner, NRC-Handelsblad, 4 juli 1987)

Sommige dingen doet men niet, zoals naar binnen gaan bij iemand die baadt. Over het algemeen stoort men iemand niet bij intieme handelingen.

Afzondering ter bescherming van privacy wordt dus op twee manieren gerealiseerd, namelijk met behulp van materiële maatregelen en ook door te vertrouwen op gewoonten en gebruiken op basis van maatschappelijke en culturele normen. Deze tweedeling wordt in de literatuur over privacy teruggevonden, bijvoorbeeld in de onderscheiden definities van privacy. Zo verwijzen Foddy en Finighan (1980) enerzijds naar Ball (1975), Schwartz (1968) en Schenk (1972) welke thave defined privacy as the ability to withdraw physically from others". Anderzijds wijzen zij op McClemens (1976) "(who) suggests that privacy might best be regarded as "that area of a man's life which, in given circumstances, a reasonable man with an understanding of the needs of a community would think it wrong to invade" ".

Beide typen middelen ter privacybescherming waren ook onderwerp van research. Zo onderscheidt Kelvin (1973), onder verwijzing naar de "environmental studies" van o.a. Proshansky, Ittelson en Rivlin (1970), twee categorieën onderzoeksthema's, namelijk 1. de studies over voor privacy belangrijke materiële omstandigheden, en 2. de studies die vooral de normen tot onderwerp hebben die van invloed zijn op priwacy. Vanuit een aan de sociale psychologie ontleend theoretisch kader tracht Kelvin vervolgens duidelijkheid te scheppen omtrent het begrip privacy in relatie tot macht en normen.

Op diverse benaderingen of beschouwingswijzen van het verschijnsel privacy door verschillende disciplines zal in paragraaf 2.3.1 nader worden ingegaan.

\subsubsection{Een zekere scheidswand}

De boven beschreven twee categorieën privacy-beschermende maatregelen resulteren beide in een soort scheidswand ussen het individu dat privacy verlangl en zijn (sociale) omgeving. "There are frontiers not artificially drawn, within men should be inviolable, these frontiers being defined in terms of rules so long and widely accepted that their observance has entered into the very conception of what it is to be a normal human being' (Sills, 1968). Een barrière dus, die niet kunstmatig is maar wordt opgeworpen door algemeen aanvaarde regels. Stillman (1978) spreekt van een persoonlijke ruimtebel die men om zich heen draagt.

Wat is de aard en functie van deze onzichtbare afscherming?

a. De genoemde scheidswand beschermt, namelijk tegen ongewenste bemoeienis van anderen. Nieuwsgierigheid kan hinderlijk zijn, dus ongewenst, ja zelfs ongezond (cf. 'ongezonde nieuwsgierigheid"), evenals een opdringerige blik, aandacht of verregaande bemoeizucht.

Het aspect van ongestoordheid en bescherming van de persoonlijke levenssfeer is een kenmerk dat terugkomt in verschillende definities of omschrijwingen van privacy. 
"Het ongehinderd (...) ergens kunnen vertoeven", zegt de Van Dille (1984), en dat 'ergens vertoeven' kan dan voorbehouden zijn aan de persoon 'alleen, in eigen kring. met een partner'. Privacy is 'the state or condition of being alone, undisturbed, or free from public attention, as a matter of choice or right' (Buchfield, 1982). Privacy, aldus Buchfield, is "freedom from interference or intrusion" - dat wil zeggen van "tussenkomst, bemoeing, aantasting, storing, stoomis, last, hinder", respectievelijk "indringing".

b. Met het oog op de beschermende functie moet de scheidswand voldoende afsluitend, zijhet niet per se absoluut ondoordringbaar zijn. De toegankelijkheid dient echter onder controle te staan van het individu dat naar eigen kewze anderen al of niet kan toelaten tot zijn privacyterritorium: 'We become what we are not only by establishing boundaries around ourselves but also by a periodic opening of these boundaries to nourishment, to learning, and to intimacy" (Simmel, 1971 ; cit. Altma, 1976). Altman (1976) bedient zich in deze dan ook van de analogie van de celmembraan "whose boundary properties change in accord with the state of the external and internal environment'. De 'scheidswand" bewerkstelligt een isolatie die betrekkelijk is, want vrijwillig gezocht en vrijwillig opgeheven: 'Privacy may be defined as withdrawal from group, with at the same time ready access to it" (Park 1924). Privacy "is a comfortable condition reflecting a desired degree of social retreat on the part of the person seeking it" (Schuster, 1976).

c. Tenslotte zij opgemerkt dat de "scheidswand' als flexibel moet worden voorgesteld, namelijk:

- diachroon: doorlopend in de tijd, zowel betreffende groeperingen binnen de samenleving (zoals blijkt uit bijwoorbeeld de geschiedenis wan het civilisatieproces, Elias 1982), als met betrekking tot het individu in zijn persoonlijke ontwikkeling;

- synchroon: privacy, de behoefte eraan en de bescherming ervan, kan zich terzelfder tijd op verschillende wijzen manifesteren ten aanzien wan verschillende (groepen van) mensen;

- intra- en interindividueel variabel: voor een en dezelfde persoon kunnen verschillende facetten uit de persoonlijke levenssfeer in verschillende mate ten aanzien van verschillende personen privacygevoelig zijn.

\subsubsection{Het object van privacy-bescherming}

Met het oog op welk resultat, welk gewenst voordeel wondt afzondering of een toestand van teruggetrokkenheid gezocht?

De "ruimtebel" beschermt, en wel "dat deel van het functioneren van een persoon dat zodanig met de individualiteit samenhangt, dat hij in beginsel geen ongewenste inmenging van en kennismaking door anderen hoeft te dulden' (Kuitenbrouwer, 1982).

Het is niet eenvoudig "dat deel" van het persoonlijk functioneren nauwkeurig te benoemen gegeven de samenhang daarvan met de individualiteit. In de literatuur is sprake van die dimensie van de levenssfeer watrin de persoon de nodige wrijheid heeft zich te ontwikkelen en te ontplooien. "Privacy affords opportunity for the individual to reflect, to anticipate, to recast, and to originate" (Park, 1924). In thet voor persoonlijke groei gewenste klimaat van autonomie (Friedlander, 1982), wan vrijheid en creativiteit 
wordt ongewenste inmenging, nieuwsgierigheid, opdringerigheid erwaren als remmend en hinderlijk, dus ongewenst. "What is perhaps the dominantreason for seeking privacy, namely, the desire to be insulated from observation, is intimately related to motives of avoiding criticism, punishment, or the discomfort of feeling inhibited' (Sills, 1986).

De 'scheidswand' werd echter hierboven $(\$ 2.2,2, b)$ als permeabel en flexibel voorgesteld: naast afscherming van zichzelf heeft de mens voor de groei van züjn persoonlijkheid ook verkeer met de samenleving nodig.

Zoalls gezegd: de betrekkelijke isolatie wordt vrijwillig gezocht en onderbroken alles binnen de grenzen van het matschappelijk acceptabele. Anderzijds kent de samenleving het individu dan wel het besloten gezelschap ook het recht, of het privilege, toe zich relatief af te zonderen. De mens heeft 'recht op privacy'.

Uit Donners beschrijving van zijn leefsituatie, voor zover hierboven geciteerd, krijgt men de indruk dat (minstens) twee dingen hem hinderen.

In de eerste plaats bemoeit een verpleegster zich met zijn sociale contacten i.c. zijin correspondentie. Inderdaad blijken in het maatschappelijk verkeer iemands sociale rollen onderwerp van privacy te kunnen zijn. Met wie iemand omgaat kan, evenals bijvoorbeeld zijn politieke voorkeur, inkomsten, leeftijd, religieuze overtuiging, iemands rol als seksueel partner, behoren tot de meer of minder strikt persoonlijke levenssfeer. Evenzo kan ook iemands rol als (ex-)patiënt of als familielid van een aan een stigmatiserende, bijwoorbeeld psychiatrische, ziekte lijdende patiënt behoren tot zijn/haar sfeer van de privacy.

In de tweede plaats wordt ongewill in ontklede toestand aangetrofien worden als inbreuk op de privacy ervaren. Dit geldt zelfs in medische situaties, zoals verwoord door een patiënte die tijdens een zaalvisite aan "vier witte mensen " werd getoond:

(..) mijn borsten waar ik (..) bijna tien jaar lang problemen mee heb. (...) Twee totaal verlepte bloemen die warm en slap naar beneden hangen. (...) En dan sta ik daar. schaamrood op de kaken, hart in de keel "voor een front dat kijkt van mijn borsten nakr mijn gezicht en terug. Nooit heb ik me meer opgelaten gevoeld dan op dat moment dat me uren lijkt te duren (NN, in: TVZ, 1984, blz. 278).

Privacy beschermt het naakte menselijke lichaam in het bijzonder voor zover het verwijst naar zaken waar een taboe op rust: seksuele activiteiten, maar ook de processen van de nitscheiding. Op deze en enige andere punten is de mens blijkbatr extra kwetsbat.

De dimensie van de levenssfeer warin het individu de nodige wrijheid heeft zich te onwikkelen en te ontplooien, is die sector van het zelf, waar, aldus Elias (1982), inferioriteitsgevoelens ten opzichte van de buitenwereld niet door middel van fysiek gewell noch met een ander soort verdediging kumen worden afgewend. De zelfbescherming komt voort uit gevoelens van schaamte en gêne. De verschuiving van de 'pijnlijkheidsdrempel' is enerzijds te zien als een uiting van een afnane van de directe angsten voor bedreiging of overweldiging door andere mensen, en anderzijds als van een versterking van de innerlijke angsten met de daarbij behorende afweer in de vorm van de dwang die de enkeling nu op zichzelf uitoefent.

Kortom: tot de dimensies van de met privacy te beschermen levenssfeer waarin het individu de nodige vrijheid behoeft zich te ontwikkelen en te ontplooien, behoren in 
feite: 1 . bepadde maaschappelijke nollen die iemand kan verwullen, en 2 . bepaalde menselijke, fysieke, maar aok emotioneel geladen verrichtingen.

\subsubsection{Inbreuk op privacy}

Een verkenning van het verschijnsel privacy is slechts zinvol indien dit wordt geplaatst binnen de gehele context van het menselijke bestaan. In de dynamische menswereldrelatie is privacy aan verandering onderhewig, zich wijzigend van moment tot moment, wan sifuatie tot situatie, van plaats tot plats en van cultuur tot cultuur. Ziekzijn behoor tot de levensomstandigheden waarin aantasting van de persoonlijke levenssfeer anders ervaren kan worden dan onder gezonde omstandigheden. Een ziekenhuisopname daarenboven kan als extra privacy-bedreigend worden beleefd.

Wat als bedreigende inmenging ervaren kan worden, wordt duidelijk bij een analyse van verpleegsituaties waarin wan privacy sprake is:

Wanneer zij twee werpleegsters tegen elkaar hoorde zeggen "Nou, dat stonk daar toch" o.id. kromp zil helemaal in elkaar, bang dat ze haar ook vonden stinken. (NN, in: TVZ, 1985, blz. 136-137)

IK sta weer op zaal en realiseer me dat de gordinen geen muren zijn en dat iedereen alles heeft kurnen horen. Ik was blif dal er niet veel gesproken was over waar ik voon opgenomem ben, en gelukkig hadden medepatienten niels kumen zien. (NN, in: TVZ, 1984, blz. 278)

Zodra vier verpleegsters zïch aan mij kwamen voorstellen terwij één van jullie collega's bezig was mij te scheren. Geschoren worden is niet leuk; je onder die tijd voorstellen nog weel minder. (NN, in: $T V Z, 1975$, biz. 89)

Er kwam een leerling naar hem toe en wroeg hem of hij mee wilde gaan. omdat hij geschoren moest worden als woorbereiding op de operatie (..) lik liep even mee naar de kamer en zag (..) drie zusters bij het bed. We schrokken allebei (..) Op een dergelijke intieme plaats geschoren worden door éen persoon is al erg genoeg. (NN, in: TVZ, 1978, biz. 546 )

De bedreigende inmenging kan gelegen zijn in de overschrijding van grenzen van respect. In de hierboven beschreven situaties - die met talloze andere uit de dagelijkse verpleegkundige beroepspraktijk aangevuld zouden kunnen worden - is sprake van inbreuk op de persoonlijke levenssfeer via respectievelijk de reuk, het gehoor, het gezicht en de tastzin, soms in onderlinge combinaties. Om deze reden kan dit soort inbreuk ook als 'zintuiglijke inbreuken' worden aangeduid (Stijnen, 1988).

Het zonder toestemming kennis nemen van intieme informatie omtrent iemand betreft in bovenbeschreven voorbeelden lichamelike verrichtingen waarop een taboe rust, inclusief de daarbij betrokken lichaamsdelen. De inbreuk kan ook betrekking hebben op het omgan met emoties of vertrouwelijkheden:

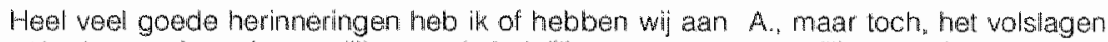
gebrek aan priwacy is vreselijken vaak dodelijk voor een vertrouwelijk gesprek. Als bezoek moest je je maar tol algemeenheden bepalen, want je weet vaak niet wat je losmaakt en dat wilden wij onzemoeder niet aandioen, zodat heel veel onder het mom van een grapje doorging, terwijl je allebei boordevol emoties zat. (NN, in: TwZ. 1985, blz. 136) 
Ook het ongevraagd kennisnemen wan imfonmatie die op het eerste gezicht minder vertrouwelijk lijkt, kan door patienten roch als inbreuk op de privacy worden beschouwd: Het is in dit verband opmerkelijk hoe in het professionele tatigebruik voor de verwerving van patiëntgegevens de uitdrukking 'anamnese whemen' wordt gebezigd. Voor het Engelse vaktaalgebruik attendeert Friedlander (1982) terecht op thet veelvuldige en kenmerkende van het gebruik van het woord "taking" voor bepaalde medische en verpleegkundige handelingen: "strangers are often raking things of the patient, such as taking the blood pressure, temperature, pulse-not measuring, but taking!'

Als andere vorm van bedreiging wan of inbreuk op de privacy, in zekere zin het tegendeel van het eerder beschreven type, dient vemeld te worden het iemand ongewild opdringen van informatie dan wel iemand ongevraagd betrekken bij hem onbekende, of door them ongewilde handelingen of situaties. Er is dan sprake van een opdringerige toenadering, bemoeizucht, té nadrukkelijke aanwezigheid van personen die men, met welke bedoelingen zij ook aanwezig zijn, het liefst zo ver mogelijk weg zou wensen.

Dit type van bedreiging of inbreuk kan zich uiten in woord, beeld en geschrift. Men denke aan de ongetwijfeld vaak goedbedoelde maar evengoed als té opdringerig ervaren 'goede raad' in geval van ziekten of ongeluk, relatie- en gezinsproblemen of andere levensvraagstukken. Of aan de stromen drukwerk die ons wekelijks komen melden waar wij onze vakanties dienen door te brengen, bij wie wij ons behoren te verzekeren, en in welke handen wij ons politieke lot dienen te leggen. 'Aan de persoon gerichte brievenbusreclame", of 'direct mail', bleek in het onderzoek van Holvast, Van Dijk \& Schep (1989) een emstiger aantasting van de privacy dan de invoering van het SoFi-nummer of dan onaangekondigd bezoek.

Het aandeel van woord, beeld en geschrift kan zich in dit geval overigens tot een minimum beperken. Alleen al de loutere aanwezigheid van iemand die een ander slechts lastig zou kúnnen vallen, kan ervaren worden als inbreuk op de persoonlijke levenssfeer. In zijn al eerder geciteerde cursiefje geeft Donner daarvan twee voorbeelden:

\footnotetext{
Soms gaat de deur alleen open en dicht en laat een volkomen onbekende gestalte zien die "Pardon' zegt. Dat zinn bezoekers van andere patiënten, die de weg niet weter. Maar dat is alles het ergste nog niet.

Zoals uit hel laatste voorbeeld blikt. kan men van de strabl zonder meer natar mijn bed doorlopen, ais men maar niemand aanspreekt. In mijh geval maken voorall ki ankzinnigen gebrwik van die mogelijkheid. Dall is het allerergste.

ik denk nu aan die jonge dame die ineens in mijn kamer stond. (...) Of aan die man die midden in de nacht het licht antstak en naast mijn bed druk op mij begor in le praten. terwill alles naar de alcohol rook. (...) (J.H. Donner, 1987)
}

Als twee verschillende vormen van bedreiging van of inbreuk op de privacy kunnen worden onderscheiden: 1 . het zonder toestemming kennisnemen van persoonlijke, intieme unformatie, waarbij in principe alle middelen kunnen worden aangewend die de zintuigen bieden ("zintuiglijke inbreuken"); en 2. het opdringen van ongewenste informatie, in woord, beeld of geschrift, of zelfs door iemands loutere ongewenste aanwezigheid ("hinderlijke benoeienis' of 'opdringerige roenadering", Stijnen, 1988). 
De aspecten die in verband met privacy onderscheiden kumen worden, kunnen schematisch worden voorgesteld als in figuur 2.1 .

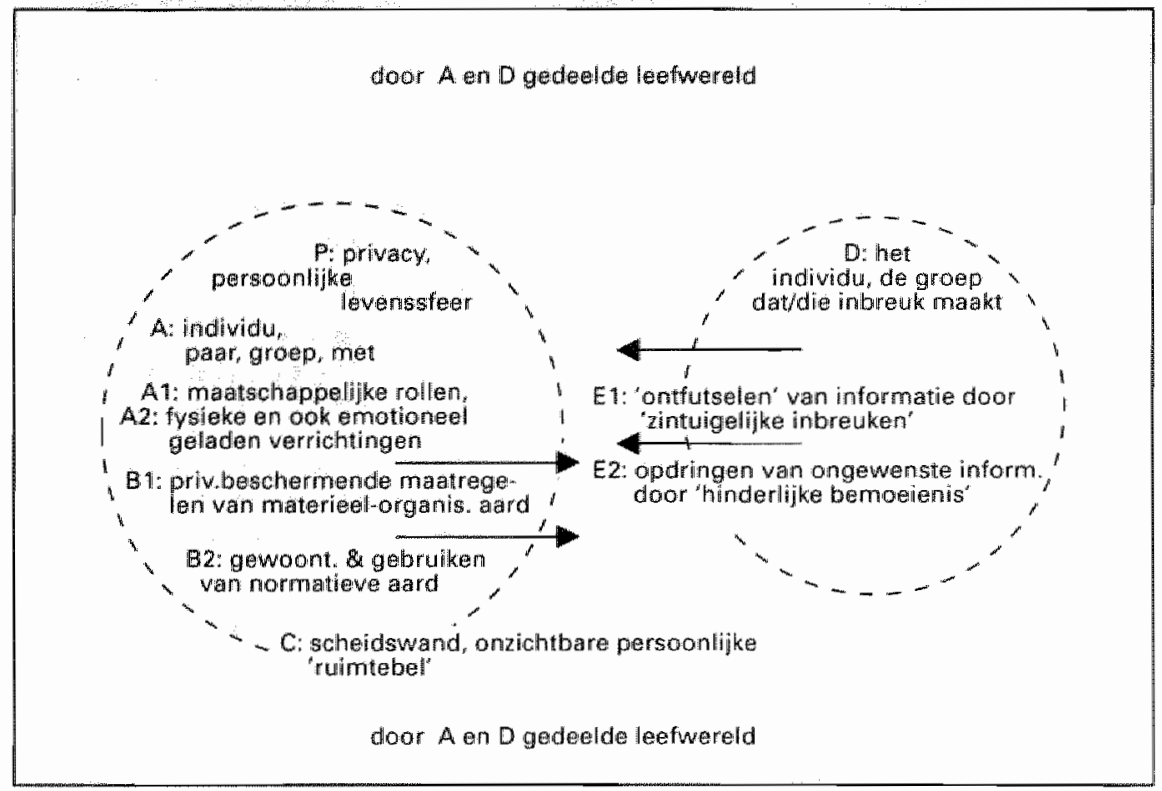

Figuur 2.1 Aspecten van privacy

Mogelijkheden tot intiem gedrag tussen A en D, zoals door Friedlander (1982) uitgewerkt naar verschillende soorten wan intermenselijke relaties, zijn in dit schema niet opgenomen.

Van Oomkes" "procesmodel van communicatie" (1986) verschilt het schema hierin, dat slechts éen rol lijkt toebedeeld aan A en D; beiden echter zijn, uiteraard, personen op wier privacy inbreuk kan worden gemaaktén die, wederzijds, op andermans privacy inbreuk kunnen maken.

Met Goffmans benadering van het fenomeen "territory" (Goffman, 1971) heeft het schema gemeen, dat territory respectievelijk privacy worden opgevat als "the good, the desired object", ter bescherming waarvan het individu een aantal maatregelen kan nemen. Op iemands privacy kan als intimiteitsterritorium door 'offenders' inbreuk worden gemaakt. Goffman noemt lichamelijke uitscheidingsprodukten van de een faeces en urime, maar ook de wind en lichaamsgeuren - als bron van mogelijke inbreuk op het territorium van de ander. Zonder territority als louter ruimtelijk op te vatten, onderscheidt Goffman acht 'territories of the self" waaronder "information preserve', de controle over de infomatie betreffende de persoon zelf - die, aldus Goffman onder verwijzing naar Westin (1967), gewoonlijk doorgaat voor privacy. 
Figuur 2.1 stelt op de eerste plaats in staat verschillende aspecten van het verschijnsel privacy te onderscheiden. Geconstateerd kan worden dat soms aftonderlijke aspecten wan het begrip met de ovenkoepelende term privacy worden aangeduid. Her gebruik van het begrip privacy blijkt nu eens betrekking te hebben op het doel: een bepaald soort zelfbescherming, dan weer op de middelen lic. strategieen en matregelen om dit doel te bereiken. Evenzo blijkt men uitspraken te doen over privacy, wanneer in feite gedoeld wordt op de "scheidswand'. De 'onzichtbare, persoonlijke ruimtebel geeft echter wel het territorium van privacy aan maar niet het object privacy als zodanig. Evenmin is privacy gelijk aan 'de dimensies van de levenssfeer waarin het individu de nodige vrijheid heeft zich te ontplooien.' Privacy beschermi juist dat 'deel wan het functioneren van een persoon dat (volgens Kuitenbrouwer, 1982) zodanig met de individualiteit samenhangt, dat hij in beginsel geen ongewenste inmenging van en kennismaking door anderen hoeft te dulden".

\subsection{Aspecten van privacy}

Uit de verkenning van thet begrip blijken de wolgende aspecten atan privacy te kunnen worden onderscheiden:

a. De aanwezigheid van een beschemende sfeer om het individu (het paar, de groep), ter bescherming van een belangrijk, blijkbaar kwetsbaar gedeelte van het "zelf", namelijk die dimensie van de levenssfeer waarbinnen het maatschappelijk verbod en de zelfdwang ten aanzien van een aantal menselijke, fysieke maar ook emotioneel geladen verrichtingen alsook van een axntal maatschappelijke rollen en posities niet gelden.

b. De mogelijkheid zich ongestoord, in vrijheid en op creatieve wijze te ontplooien, in relatie tot een soms als té opdringerig ervaren wereld.

c. De al dan niet door de buitenwereld gerespecteerde bescherming wordt verkregen door vrijwillige isolatie die zelf gezocht en zelf opgeheven kan worden en die wordt bewerkstelligd door het nemen van (im)materiële maatregelen en door zich te beroepen op regels, gewoonten, normen.

d. Het al dan niet erkende of geclaimde recht op of een privillege van isolatie.

a. De maatregelen en het beroep op gebruiken ter privacybescherming hetzij passief (vermijden, zich afsluiten voor), hetzij actief (beheersing en hanteren van de situatie; controle).

f. De maatregelen en het beroep op nomen tegen de als bedreigende inmenging erwaren "zintuiglijke inbreuken" (met behulp waarvan weelal intieme informatie aan de persoon wordt ontfutseld), alsook tegen opdringerige toenadering (met alle blootstellingen aan onwelkome informatie vandien).

Wat betreft de situering van priwacy in deze studie bimnen het kader van ziek-zijn en zorgverlenen, zal de aandacht voornameljjk uitgaan naar gedragswetenschappelijke aspecten van privacy. Binmen laatstgenoemde optiek kan een globaal onderscheid worden aangebracht tussen enerzijds accenten op hetgeen mensen doen ter bescherming van hun privacy $(B$, verder uit te werken in $\$ 2.4 .1$ ), en anderzijds de inwloed van de ongeving op privacybescherming ( $C$, nader bepaald in $\$ 2.4 .2$ ). 


\subsubsection{Privacy als doel van handelen}

Privacy als de beschermende sfeer rondom het individu is niet slechts het uiteindelijke resultaat van toevallige factoren in iemands leefwereld. Zoals bleek uit $\$ 2.2 .1$, kan privacy actief verworven en gehandhaafd en beschermd worden, enerzijds met beliulp van maatregelen van materieel-organisatorische aard (in fig. 2.l aangeduid als BI), anderzijds door zich te verlaten op gewoonten en gebruiken van normatieve aard (B2 in fig. 2.1). Voor beide mogelijkheden blijken er aanknopingspunten in diverse gedragswetenschappelijke theorieën.

Ad B1: "Maatregelen van materieel-organisatorische aard": Waar in bedoelde theorieèn uitspraken worden gedaan over privacy, blijkt het accent te liggen op controle en keuzevrijheid (Brandeis, 1972). Enkele van de meest gangbare zijn de volgencle:

In developmental-learning theories wordt, bijvoorbeeld door Ittelson, Proshansky, Rivlin \& Winkel (1974), gesteld dat gevoelens van privacy en de matregelen die men neemt ter bescherming ervan, door kinderen worden aangeleerd in de loop van de socialisatiefase. Belangrijk in deze optiek is het groeiende besef bij het kind, dat het controle kan uitoefenen op de processen van bescherming van en inbreuk op privacy.

In de interpersonal theories, waarvan Jourard (1971) en ook Altman (1975) gezien kunnen worden als belangrijke vertegenwoordigers, neemt het begrip 'self-disclosure' als contrasterende antipode van privacy een belangrijke plaats in: is privacy bescherming, een worm van zelf-afdekken, self-disclosure is dan 'zelf-onthulling', het vrijgeven van kennis omtrent de eigen persoon.

Functional theories: in het werk van Proshansky, Ittelson \& Rivlin (1974) is een aanzet gegeven tot een functionele, analytische benadering van privacy. Naar de mening van deze auteurs komt "privacy genieten " overeen met kunnen beslissen wie al dan niet controle zal uitoefenen over ons gedrag. Deze keuzevrijheid werd door Johnson verder uitgewerkt, als 'those behaviors which enhance and maintain one's control over outcomes indirectly by controlling interactions with others' (1974).

Ondanks de nogal voluntaristische inkleuring van het begrip privacy in de genoemde theorieěn, wordt daarin toch ook een zekere rol toebedeeld aan de omgeving. Als zodanig kan de environmental psychology gesitueerd worden tussen enerzijds de architectonische benadering met het absolute primat van de omgeving (zie $\$ 2.4 .2$ ), en anderzijds de symbolisch interactionistische benadering met het primaat van de tussen-menselijke betrekkingen (zie ad B2, hieronder).

Ad B2: Gewoonten en gebruiken van normatieve aard beschermen eveneens de persoonlijke levenssfeer, zodat privacy ook gedefinieerd of omschreven kan worden met behulp van normatieve constructies. Enkele gangbare theoretische benaderingen zijin cle volgende:

In de social-normative theories wordt privacy gezien als gestructureerd en geinstitutionaliseerd gedrag. Deze theoretische stellingname werd verder uitgewerkt door Schwartz (1968) en Kelvin (1973). Normen met betrekking tot privacy functioneren precies zoals normen betreffende ieder ander sociaal contact: zij stabiliseren de maatschappelijke orde, en wel op twee manieren. Enerzijds schrijven zij voor wat mensen behoren te doen in afzondering, anderzijds regelen zij wie mag beschikken 
over welke informatie omtrent wite, en hoe daarmee moet wouden omgegaan:

Het symbohsch interactionisme stelt dat normen, inclusief gedragsnegels, door de samenlewing worden gemaakt, en dus ook gewijzigd of door andere vervangen kunnen worden. In de viteenzetting van Foddy \& Finghan (1980) higt het uitgangspunt in het "zelf", gedefinieerd als "the individual's perception of how others perceive and evaluate him'. Voorzover iemand zich erom bekomment hoe een ander tegenover hem staat, wil hij controle uitoefenen op de toegang tot (infomalie over) hemzelf, ondat van die informatie die de ander over hem heeft afhangt welke identiteit hij heef of geacht wordt te hebben - althans wanneer identiteit zoals door de betreffende auteurs wordt opgevai als 'an individual's idea of the type of person he wants to be in the eyes of others'. Dit leidt dan tot de omschrijung van privacy als 'the possession by an individual of control over information that would interfere with the acceptance of his claims for an identity within a specified role relationship" (Foddy \& Finighan, 1980).

Over het algemeen geldt dat de hier genoemde theoretische benaderingen zelden als strikt van elkaar te onderscheiden scholen of stromingen zijn te beschouwen. Dit gebrek aan duidelijkheid omtrent theoretische fundering is een van de oorzaken van de conceptuele complexiteit die ten aanzien van privacy blijkt te bestaan.

\subsubsection{Privacy als omgevingsfactor}

In de benadering van privacy door de environmental psychology wordt expliciet belang gehecht aan beinvloedende factoren vanuit de omgeving op privacybeleving. Het betreft dan materiële en architectonische gegevenheden, getuige studies over privacy in de meest uiteenlopende lokale settings, zoals de bibliotheek, de slaapzaal, school en kantoor, verschillende soorten woonwijken, het hotel "de kazerne en het ziekenhuis. In dit type onderzoek omtrent privacy wordt, aldus Archea (1977), de omgeving grotendeels bezien in termen van nomatieve of symbolische kwaliteiten die er door de gebruikers of bewoners arn worden toegekend.

Voor architecten die zich beroepshalve met privacy bezig houden, vormt de ongewing "a source of error which must be experimentally or statistically controlled in order to preserve the scientific integrity of behavioral constructs" (Archea, 1977). Deze opvatting impliceert, dat our task should be to reconceptualize the nature of the physical environment so that the relationship between it and human behavior can be fully elaborated' (Archea, 1977).

De 'scheidswand' of 'persoonlijke ruimtebel' (C) die verondersteld word ter privacybescherming, wortt in belangrijke mate tot stand gebracht en gehandhaafd door omgevingsfactoren, al of niet architectonisch vorm gegeven in ruimtelijke voorzieningen. Een dichte deur maakt het in principe mogelijk ongehinderd ontkleed rond te lopen. Het feit echter dat een deur, zoals bij Donner, "ieder ogenblik opengednan (kan) worden" door ongenoden, personeel en bezoekers, maakt hen tot potentièle indringers in die intimiteit. Helas ontbreekt het de geimmobiliseerde patiënt aan middelen de deur als priwacybeschermer naar believen te hanteren...

De deur dient, volgens de analyse van Seligman (1982), als hulpmiddel om sociaal contact te initiëren, te handhaven, af te sluiten, of te vermijden - en ook, volgens Popken (1988), om dit contact te segmenteren. De deur, en ook het bedgordijn of het kamerscherm, is iemands hulpmiddel bij het reguleren van contacten en het kavaliseren van 
informatiestromen. Deuren zijn soms efficiênte hulpmiddelen: zij hebben soms alleen aan de binnenkant dearknoppen, zij kunnen soms van binnenuit vergrendeld worden, de "beherder' van een deur kan het zelfgekozen isolement met een extra mededelling onderlijnen: bezet, belet, niet storen, geen toegang. De deur van de ziekenkamer blijkt vaak minider efficiènt als privacy-beschermer: de patiënt zelf is niet of nauwelijks in staat tot het beheer daarvan. Nog minder efficiënt is het scherm of het gordijn:

Ik sta weer op zaal en realiseer me dat de gordijien geen muren zijn en dat hedereen alles heeft kunnen horen. Ik was blij dat er niet veel gesproken was over waar ik woor opgenomen ben, en gelukkig hadden medepatienten niets kumnen zien. (NN, in: TVZ, 1984 , blz. 278)

De deur illustreert de doorlatendheid van de "scheidswand"; deze permeabiliteit houdt de mogelijkheid van communicatie open. Het individu heeft enerzijds contact ter informatie nodig, namelijk in het kader van de persoonlijke rust, creativiteit en groei. Anderzijds heeft het individu behoefte aan contact ter verstrekking van informatie. Uit beider hoofde vreest de patiënt soms het isolement dar kan ontstaan als de communicatie met de zorgverlener wegvalt. Voor sommige auteurs is de communicatie ter circulatie van informatie en de controle die het individu moet kunnen uitoefenen op deze circulatie, de kern van privacy. Privacy is dan 'the selective control of communication' (Bennett, 1967). En: "Privacy is not simply an absence of information about us in the mind of others, rather it is the control we have over information about ourselves' (Fried 1968, cit. in Curtin 1981).

Anderen gaan hierin nog verder en spreken behalve over behoefte aan informatie liever over recht: 'the right of the individual to decide what information about himself should be communicated to others and under what conditions" (Westin, 1967), dat wil zeggen privacy als de aanspraak van individuen, groepen of instellingen zelf te bepalen wanneer, hoe en in welke omvang informatie over henzelf naar anderen wordt gecommuniceerd.

De aanknopingspunten ten aanzien van privacy-aspecten in diverse gedragswetenschappelijke theorieën zijn als volgt samen te vatten (Schema 2.1).

Hoewel, zoals uit het schema blijkt, omschrijvingen en definities van (aspecten van) privacy op sommige punten overeenkomst vertonen, ontbreekt het duidelijk aan éen allesomvattend concept. Privacy wordt, in willekeurige volgorde, gezien als een 'legal-political prerogative' (Westin, 1967), of als een 'emotional state' (Bates, 1964), of ook als een 'informational outcome state between social actors resulting from selective communication' (Jourard, 1966).

Drie gedragswetenschappelijke oriëntaties op het fenomeen privacy kunnen worden onderscheiden:

1. Benaderingen waarbij de nadruk wordt gelegd op autonomie en keuzevrijheid. Kenmerkende definities in deze van privacy zijn "a claim to immunity from intrusion or control by others' (Proshansky, Ittelson \& Rivlin, 1970) en 'the ability to control the degree to which people and institutions encroach upon one"s life' (Marshall, 1974).

2. De normatieve benadering, vooral gehanteerd vanuit de sociologie: privacy be- 


\begin{tabular}{|c|c|c|}
\hline $\begin{array}{l}\text { Aspectein van privacy, } \\
\text { onderscheiden in fig. } 2.1\end{array}$ & Theoretische orientaties & Nadruk op \\
\hline $\begin{array}{l}\text { B1: Maatregelen van } \\
\text { materiele aard ter } \\
\text { bescherming van de privacy }\end{array}$ & $\begin{array}{l}\text { Environmental Psychology: } \\
\text { Developmental-learning } \\
\text { theory: } \\
\text { Marshall, Proshansky, } \\
\text { Pivlin, Ittelson } \\
\text { Interpersonal theory: } \\
\text { Jourard, Altman } \\
\text { Functional theories: } \\
\text { Johnson, Proshansky, } \\
\text { Ithelson, Rivlin }\end{array}$ & $\begin{array}{l}\text { automomie, } \\
\text { heuzeviiheid, } \\
\text { controle van de } \\
\text { situatie. } \\
\text { privacy als } \\
\text { tweezijdig proces }\end{array}$ \\
\hline $\begin{array}{l}\text { B2: Beroep op gewoonten } \\
\text { en gebouiken wan } \\
\text { normatieve atard }\end{array}$ & $\begin{array}{l}\text { Social-normative theory: } \\
\text { Scluwartz, Kelvin } \\
\text { Symbolic interactionism: } \\
\text { Foddy \& Finighan }\end{array}$ & $\begin{array}{l}\text { privacy als sociaal } \\
\text { gedrag }\end{array}$ \\
\hline $\begin{array}{l}\text { C2: Het aspect van } \\
\text { "doorlaatbaarheld" van de } \\
\text { peirsoonligke ruimtebiel" }\end{array}$ & $\begin{array}{l}\text { Bouwkunde: } \\
\text { Archea } \\
\text { Communicatie-theorie: } \\
\text { Jourard, Westin, Bernet, } \\
\text { Curtin }\end{array}$ & $\begin{array}{l}\text { privacy als resulkaat } \\
\text { van architectuur, } \\
\text { circuleren van } \\
\text { informatie en } \\
\text { controle daarop }\end{array}$ \\
\hline $\begin{array}{l}\text { Multidimensionele } \\
\text { benadering }\end{array}$ & $\begin{array}{l}\text { Westim, Wilmoth, } \\
\text { Proshansky, Ittelson, Rivilin }\end{array}$ & \\
\hline
\end{tabular}

Schema 2.1 Oriëntaties op Privacy

schermt het gedrag dat ofwel normatief neutral is dan wel waaraan de samenleving als bij stilzwijgende afspraak waarden hecht.

3. Informatie-georiënteerde benadering, waarbij de nadruk ligt op de selectieve controle van de informatie over het persoonlijke 'zelf' (Jourard 1966, Westin 1967).

\subsection{Conclusies en suggesties}

\subsubsection{Conceptuele vaagheid}

Ter verklaring van het feit dat in de jaren zestig en zeventig over het fenomeen privacy weinig fundamentele publikaties beschikbaar waren, geeft Kelvin (1973) de volgende redenen:

1. Het woord privacy heeft in het gewone spraakgebruik iets sacraals; als zodanig rust er een taboe op dat zelf weer door privacy wordt beschermd.

2. Experimenteel onderzoek aangaande privacy wordt al gatw een inbreuk op privacy geachl.

3. Het concept privacy gaat vanuit experimenteel-wetenschappelijk oogpunt gebukt onder verregaande vaagheid.

De verkenning van het begrip privacy, zoals in deze studlie ondernomen, mak duidelijk dat van conceptuele vaagheid niet alleen sprake is op het miveau van het 
normale, dagelikse tadgebruik. In wetenschappelike literatuur over aspecten van privacy in met rame de gezondheidszorg wordt conceptuele vaagheid in de hand gewerkt door onvoldoende afbakening tussen min of meer aan elkaar verwante of analoge begrippen, als territorialiteit, personal space, intimiteit, secrecy, vertrouwelijk heid, autonomie.

Vervolgens word de conceptuele vaagheid mede veroorzaakt door het feit dat verscheidene wetenschappelijke discipines privacy bestuderen binnen onderling vaak zeer verschillende theoretische kaders. Van nawkeurig van elkaar te onderscheiden theoretische stromingen is geen sprake. In tegendeel, werk van sommige auteurs kan gevoeglijk worden gesitueerd binnen uiteenlopende benaderingen van het verschijnsel privacy. Complicerend daarbij is dat sommige schrijvers (Westin, Wilmoth) bewust opteren voor multidimensionele benaderingswijzen.

De gedragswetenschappelijke benaderingswijzen bleken globaal te kunnen worden teruggebracht tot drie te onderscheiden orièntaties, welke elk afzonderlijk verschillende aspecten van het verschijnsel privacy als invalshoek bleken te nemen, gezien de nadruk op achtereenwolgens autonomie en keuzevrijheid, normen en waarden, en tenslotte selectieve controle van de informatie over het individu.

\subsubsection{Privacy als pars pro toto}

In de wetenschap die zich richt op het verplegen (waar men hoog opgeeft over de privacy van de patiént) blijken de bijdragen aan de verheldering, analyse en operationalisering van het begrip privacy beperkt tot enkele studies (Schuster 1976 , Bloch 1978, Rawnsley 1980, Stijnen 1988). Voor zover de verpleegkundige vakliteratuur zich met de privacy van de patiënt bezighoudt blijkt dan nog voomamelijk alleen de informatiedimensie aan de orde.

Een blik op de Nederlandstalige verpleegkundige vakliteratuur over de laatste vijftien jaren resulteert in de constatering dat in adviezen, nota"s, commentaren en artikelen 'de privacy van de patiënt' zich goeddeels lijki te beperken tot zorgvuldig omgaan met persoonsregistratie en databestanden (Schrik-van Bodegom 1980, De Waardr 1983, Aarts \& Louwerse 1985, Aarts 1988). In het algemeen geldit de door sommige ziekenhuisbestuurders geuite klacht 'privacy leeft niet', behalve in deze beperkte, zeer specifieke betekenis van her woord die patiènten niet in eerste instantie aan deze term blijken te hechten.

\subsubsection{Inbreuk op privacy invalshoek theoretische benadering?}

Uit het privacymodel (fig. 2.1) wartoe de verkenning van het concept privacy heeft geleid, blijkt dat, bij het ontwerp van het theoretisch construct, over het algemeen genomen de persoon die de privacy ervaat als uitgangspunt of als invalshoek dient. Privacy wordt gekoppeld aan hetzij maatregelen die het individu neemt om zijn privacy to beschermen, hetzij aan nomen waarop men zich beroept met het oog op ditzelfde. resultaat, hetzij an kenmerkende eigenschappen van de beschermende sleer on het subject heen. Geen van de door ons gesignaleerde theoretische benaderingen zocht haar uitgangspunt bij degene die inbreuk op iemands privacy maakt (zie fig. 2.1 onder D), noch in een of enkele van diens storende gedragingen (idem, onder E1 en E2).

Toch zou het ontwerpen van een dergelijke theoretische benadering in overweging 
genomen kunnen worden, met name vanuit verplegingswetenschap. Her proces van verplegen wordt immers veelal woorgesteld als een intermenselijk gebeuren, waaraan zorgverlener en zorgvrager beiden deelnemen, met eigen verantwoordelikheden en eigen specifieke inbreng. Zowel de verpleegkundige als de patient kumnen daarbij de grenzen van elkaars persoonlijke levenssfeer geweld aandoen of zelfs overschrijden. Zowel de verpleegkundige als de patiènt kan veroorzaker en slachtoffer zijn van de verstoring van privacy.

In het kader van de hier bedoelde wederkerigheid behoeft confrontahie van zorgverleners met ziekteverschijnselen, mismaaktheid en handicaps stellig nader onderzoek. Daarbij speelt de vraag: in hoeverre wordt de confrontatie met een zwaar zieke, hevig lijdende, ernstig mismaakte patiënt ervaren als een inbreuk op de persoonlijke levenssfeer van zowel de zorgvrager als de zorgwerlener? Mutatis mutandis speelt dezelfde vraag woor de confrontatie met een aantal lichamelijke functies die juist tot voor de eigen intimiteit van de patiènt voorbehouden beperkt dienen te blijven (zoals overgeven, sputum opgeven, zich ontlasten, menstruatie en erectie).

Wat deze laatste voorbeelden betreft kan zelfs gesteld worden dat het choquerende karakter eigen is aan confrontaties met bepaalde lichamelijke met name excretiefuncties, maar ook met de produkten daarvan. Onderstaande beschrijving door Hofland (1986) illustreert dit plastisch:
(...) De zwaarste, de meest weerzinwekkende onder de keine invasies is de stank van (anderen). De onzichtbare muur van walgelijkheid waar je doorheen moet als je kort na je voorganger de wc binnenkomt, de latrines van de kazernes en de stations zogoed als het privaat van de directie waarheen je wordt verwezen om 'je handen te wassen'. Via de neus wordt het hele wezen belaagd, en hetzelfde gebeurt met je oor als je gedwongen bent, een wo te gebruiken die deel uitmaakt van een batterij, waarbij de schotten fussen de compartimenten niet tol het plafond reiken. (...)
Ze zijn in strijd met al onze moderne zorgen om wat we noemen de onaantastbaarheid wan de persoonlijke levenssleer. Maar wat de neus en oren kan overkomen, is gering wergeleken bij het allerbrutaalste wat soms de ogen te wachten staat: de aanblik wan de drol wan je vaorganger op het witte porcelein. Dit is, dunkt mij, het gemeenste wat op dit gebied het netwies kan raken. (...)

Het is opvallend, hoezeer beschrijvingen van het nemen van deze en dergelijke sensorische en emotionele horden door verpleegkundigen in hun dagelijkse werk onvbreken in de verpleegkundige literatuur. 



\section{Het normale defecatiepatroon}

\subsection{Inleiding}

Wie zich in de gezondheidszorg buigt over het afwijkende, moet kunnen refereren aan het normale. Obstipatie, diarree en andere afwijkingen worden gedefinieerd in relatie tot het normale ontlastingspatroon (Connell e.a., 1965). Ook de diagnose betreffende pathologische processen wordt gesteld in vergelijking met de normale situatie, bijvoorbeeld de diagnose van het coloncarcinoom (Jones, 1976) of van het spastisch colon (Drossman e.a., 1982). Ook het effect van de therapie kan in veel gevallen slechts worden afgewogen in relatie tot een normale situatie: het effect van bijvoorbeeld voedingsvezels of van andere dieetmaatregelen kan nauwkeuriger worden bepaald indien het normale defecatiepatroon van patiënt of cliënt bekend is (Devroede, 1978).

In het algemeen, dat wil zeggen bij ziekenhuisopname zonder specifieke defecatieklachten, beoogt de verpleegkundige de zorgverlening te oriënteren op omstandigheden van de patiënt die als normaal aangeduid kunnen worden (Hunt \& Marks-Maran, 1980). Het normale defecatiepatroon van de zorgwrager wordt bij diens opname op de verpleegafdeling genoteerd: verpleegproblemen omtrent de stoelgang zullen blijken uit een vergelijking tussen de situatie van de patiënt op de verpleegafdeling en diens normale defecatiepatroon.

De patiënt in het ziekenhuis dagelijks vragen of deze het afgelopen etmaal 'ontlasting heeft gehad" ("opened their bowels", "est alle à la selle" - het betreft hier een internationaal gebruik), is een van de routinemalige handelingen die doet vermoeden dat onder verpleegkundigen een gemeenschappelijk beeld bestaat omtrent een "nomaal defecatieparroon". Normaal voor een patiënt zou een dage lijkse stoelgang ziji; de kleur" van de ontlasting moet (licht)bruin zijn, de geur "over het algemeen niet sterk' (Van den Bergh-Braam, 1979): bij afwijkende kleur of geur moet de verpleegkundige de faeces wan de patiën bewaren ter nadere inspectie door de arts. Helzelfcle word gedaan bij afwijkende consistentie - ter registratie waarvan in de medische status of op de temperatuurlijst de zorgverleners beschikken over een geeigend notatiesysteem van verticale of min of meer overhellende streepjes en dito slingertjes. 


\subsection{Vraagstelling}

Inzicht verkrigen in het nomale defecatie patroon is dus gewenst vanuit de optiek van verpleegkundige diagnose en interventie.

De diagnose, in de letterlijke betekenis wan het woord (ota-yyvwok $\omega=$ kennen doorheen uiterlijke tekenen), vindt plaats aan de hand van kenmerken die wat betreft het defecatiepatroon in ieder geval lichamelijk van aard zijn. De verpleegkundige diagnose is mogelijk vanwege hetgeen direct, concreet zichtbaar is aan het defecatiepatroon. "De verpleegkundige heeft "toegang" tot de patient via het aspect van de lichamelijkheid' (Van der Bruggen, 1987).

Om deze reden wordt van het 'nomale defecatiepatroon' in dit deelonderzoek met name de lijfelijke kant bestudeerd. De onderzoeksvraag luidi:

Hoe manifesteren zich in een gezonde papulatie enkele humaan-biologische kenmerken wan het 'normale defecatiepatroon'?

Daarbij wordt 'normaal' begrepen in de zin wan het gewone, het alledaagse, Met vanzelfsprekende, uiteindelijk als: het meest gebruikelijke, het meest voorkomende.

Het begrip normaal heeft, aldus Canguilhem (1966, 1975), globaal genomen twee betekenissen. Normal is op de eerste plaats "un fait capable de description par recensement statistique': het gemiddelde van een kenmerk van een soort, of een veelheid van individuen van de soort met gemidideld dit kenmerk, eventueel met afwijkingen binnen een toelaatbaar geachte marge (Canguilhem, 1975).

'Normal' in de tweede betekenis is "un idéal, principe positif d'appréciation, au sens de prototype ou de forme parfaite" (Canguilhem, 1975). Deze tweede betekenis houdt uiteraard verband met de eerste betekenis van normaal: datgene wat statistisch gezien het meest blijkt voor te komen, kan tot ideaal, tot norm worden verheven. In deze zin wordt door sommigen eén stoelgang per dag tot norm verheven, bijvoorbeeld door verplegenden en patiënten in de ziekenhuissituatie - wat leidde tot grote ongerustheid bij een van onze respondenten, die thuis gewend was één keer in de veertien dagen naar het toilet te gaan.

In een profielschets zullen die kenmerken van het ontlastingspatroon worden opgenomen die in het onderzoek het meest overeenkomstig de gemiddelden scoren. Daarbij moet overigens vermeden worden dat het normale in deze betekenis als absoluut normatief zou worden opgevat, waarnaast het zeldzame of het afwijkende als mislukking of uiteindelijk als absurd zou contrasteren.

\subsection{Literatuurresearch}

De stoelgang is een menselijke verrichting die plaatsvindt indien aan enkele voorwaarden van fysiologische aard is voldaan: spijsverteringskanaal, zenuw-en spierstelsel en bloedsomloop functioneren naar behoren. Resten van de voedselinname, gistings- en rottingsprodukten, atbraakprodukten van de gal (die de kleur geven aan de faeces), veel bacterièn en afscheidingsprodukten van de dikke darm (water, zouten en slijm), vormen 
te zamen de faeces. Deze hopen zich op in de endeldaim en worden door krachtige spierbewegingen vandaar naar het rectum on vervolgens door de anus naar buiten gedreven. De uitscheiding vindt, globall genomen, eenmaal per 24 uur platats - met, voor sommigen, een marge van enkele keren daags tot een keer per week of zelfs per veertien dagen. De ontlasting vindt plaats onder omstandigheden wasraan althans de westerse mens bepaalde eisen stelt betreffende materièle voorzieningen, relatieve isolatie en hygiëne.

Het veronderstelde normale defecatiepatroon wordt in leerboeken verpleegkunde niet of zeer summier beschreven. Men beperkt zich meestal tot het gewicht van de faeces: $150-200$ gram per 24-48 uur, 100-200 gram of 125-300 gram per dag, volgens achtereenwolgens Agathe \& Kerckhoffs (1969 ${ }^{16}$ ), Van den Bergh-Bratm (1979) en Van der Peet (1984) - zonder dat overigens het routinematig wegen van de faeces der patiënten behoort tot de verpleegkundige taakstelling. Verder wordt de kleur en de geui van de ontlasting vermeld (bruin, resp. niet te sterk ruikend), alsook de consistentie (halfvast). Het normale van het ontlastingspatroon valt vooral af te lezen uit de behandeling van het afwijkende. Genoemde leerboeken, alsook Van der Moolen \& Quanjer (1967 $)$, DuGas (1985), Juchlie (1980) en het standaardwerk van Virginia Henderson (1975), behandelen uilgebreid diarree en vooral obstipatie - waarbij de onderliggende idee inderdaad de dagelijkse, of tenminste de geregelde stoelgang van patiënten blijkt. Tevens beschrijven de leerboeken gedetailleerd het macroscopisch onderzoek door de verplegenden: inspectie van de faeces op galstenen, pus en slijm, ingeslikte voorwerpen, en parasieten als maden, spoelwormen en lintwomen - daarmee de idee bevestigend van de verpleegkundige als "verlengde arm" bij medisch-diagnostische en/of therapeutische activiteiten (Van der Bruggen, 1985).

In de loop van de ontwikkeling der geneeskunde zijn veel aspecten van de uitscheiding (uiteraard) onderwerp van wetenschappelijk onderzoek geweest (Wright, 1974), zodat omtrent sommige aspecten van uitscheidingsproces en -produkten de nodige kennis aanwezig is. Literatuurresearch met behulp van de computer op zowel de medische als de gedragswetenschappelijke vakliteratuur van de laatste 15 jaren (op trefwoorden als defecation, constipation, diarrhea) resulteerde in opgave van ongeveer 600 publikaties.

Van het defecatiepatroon blijkt de frequentie van de ontlasting het meest bestudeerd (Connell e.s. 1965, Wright 1974, Jones 1976, Gill 1979, Drossmann e.a. 1982, Frexinos 1982, Van der Bruggen 1985, Macdonald \& Freeling 1986, Van der Kooij 1987. Sandler 1987). Deze studies leveren echter geen gelijkJuidencle informatie omtrent de stoelgangfrequentie. De betreffende onderzoekspopulaties blijken zich zelden te lenen voor onderlinge vergelijking. Soms blijken respondenten benaderd uit beperkte leeftijdscategorieèn: jonge volwassenen (Sandler, 1987), personen vanaf 40 jaar (Jones, 1976), of ouderen (Macdonald \& Freeling, 1986). Soms ook participeren alleen bepaalde bevolkingsgroepen in het onderzoek: universiteitsstudenten en ziekenhuispersoneel bij Drossman e.a. (1982) en bij Sandler (1987). Connel. e.a. (1965) recruteerden hun respondenten uit de sollicitanten die zij ter medische keuring kregen voor een baan in de industrie. Soms, tenslotte, werd informatie over het normale defecatiepatroon retrospectief (Wright 1974 , Van der Bruggen 1985, Van der Kooij 1987) danwel bij rechtstreekse benadering van respondenten ingewonnen (Tabel 3.1). 
Tabet 3.1 Frequentie van de stoelgang: vergeliking gegevens uit enkele onderzaeken, in percentages

$<4 x$ perweek $5-9$ perweek $>10 \times$ per week

a. retrospectie:

Tolaal

Wright, 1974

Van der Bruggen. 1985

Van der Koolf, 1987

16

21

63

56

64.

21

23

12

$100 \%$

24

$100 \%$

$100 \%$

b. rechtstreekse benadering:

Gill, 1979

Frexinos, 1982

21

75

76

4

$100 \%$

$9 \quad 76 \quad 15 \quad 100 \%$

De diversiteit wan de informatie omtrent de defecatiefrequentie is er aanleiding toe, de frequentie op te nemen bij te bestuderen humaan-biologische kenmerken van het normale defecatiepatroon.

Behalve omtrent de uitscheidingsfrequentie werd eveneens, zij het in veel mindere maté, gepubliceerd over de consistentie van de faeces (Connell e.a. 1965; Gill 1979; Van der Kooij 1987). In die studies wordt de consistentie van de ontlasting voomamelijk gezien in relatie tot obstipatie (Connell, 1965), of tot de defecatiefrequentie, tot ziekten, medicijngebruik en lichamelijk ongemak bij de stoelgang (Gill, 1979).

Ook de consistentie van de faeces kan opnieuw worden bezien, in het perspectief van het normale defecatiepatroon.

Tenslotte leveren enkele publikaties informatie over de regelmatigheid van het ontlastingspatroon. Zowel Jones (1976) als Macdonald \& Freeling (1986) informeerden naar de regelmatigheid van de stoelgang zoals gepercipieerd door de respondenten zelf. Velen bleken regelmatigheid van het patroon te associèren aan een ontlasting per dag of per twee dagen, maar eveneens aan een zelfde moment gedurende de dag: $33 \%$ bij Macdonald \& Freeling (1986), en 'velen' (zonder nadere specificatie) bij Jones (1976), die een stoelgang op 10 tot 30 minuten na een maaltijd opgaven, van wie de meesten na het ontbijt.

De regelmaat van het defecatiepatroon kan, tenslotte, dus eveneens nader worden onderzocht.

Frequentie, geur, kleur, hoeveelheid, consistentie en regelmaat blijken dus de humaan-biologische kenmerken van het ontlastingspatroon waarvan de verpleegkundige c.q. de gezondheidswetenschappelijke literatuur melding maakt. Tot het normale defecatiepatroon kunnen vervolgens ook de duur van de stoelgang alsook het uitstellen ervan worden gerekend. Ervaring op de verpleegafdeling leert dat uitstelgedrag in variaties voorkomt: vaak of minder vaak de ontlasting uitstellen, lang of minder lang; zelfs zijn er patiënten voor wie het zich ontlasten in de ziekenhuissituatie dermate problematisch is, dat zij de stoelgang uitstellen tot na het ontslag uit het ziekenhuis, wat veertien dagen $k$ an duren.

Tenslotte kan ook de plaats van de ontlasting worden gerekend tot de kenmerken van het defecatiepatroon. 


\subsection{De keuze voor humaan-biologische kenmerken}

Hoe manifesteren zich in een gezonde populatie enkele humaan-biologischo kenmer ken van het normale defecatiepatroon? Te bestuderen humaan biologisehe kenmerken, zoals genoemd:

1. De frequentie van de stoelgang, dus het all dan miet plaatsvinden van een ontlasting, gerelateerd aan een tijdsspanne.

2. Hoedanigheden wan de faeces, namelijk:

- de kleur, die bij normale ontlasting alle schakeringen bruin kan ventonen;

- de geur, die de geur is van verteerd voedsel, gistings- en rottingsprodukten;

- de hoeveelheid per stoelgang geproduceende faeces;

- de consistentie, hetgeen betrekking heeft op de vastheid van de faeces. Voor een eenduidig begrip van "consistentie" werd in het onderzoek aanvankelijk onderscheid gemaakt tussen de vorm (brijig, hoop en knikker- of keutelwormig) en het aspect ( $z a c h$ /dun, nomaal en hard/dik) van de ontlasting.

3. Tijdsaspecten, namelijk:

- het tijdstip gedurende de dag waarop de stoelgang plaatsvindt;

- de duur: de tijd die besteed wordt aan een stoelgang;

- uitstel: de tijd dat, hoewel men aandrang heeft, de stoelgang tot later wordt uitgesteld;

- regelmaat ofwel stabiliteit: de mate warin kenmerken van het nomale defecatiepatroon, als frequentie, duur, hoeveelheid, vom, bij herhaling worden vastgesteld.

4. De plaats van de stoelgang: de lokatie waar men naar de wc gaat, en die gelegen kan zijn in een omgeving waarmee men vertrouwd is (thuis), of niet (bijvoorbeeld in een trein).

Bepaalde humaan-biologische kenmerken worden in de bestudeerde literatuur gerelateerd aan enkele sociaal-demografische variabelen. Leeftijd en geslacht blijken daarop van invloed (Wright 1974, Jones 1976, Gill 1979, Macdonald \& Freeling 1986, Sandler 1987), al sook de sociale herkomst van de respondenten (Connell e.a. 1965, Drossmann e.a. 1982, Sandler 1987). Tenslotte wordt ook 'klein' lichamelijk ongemak, namelijk wat doorgaans niet als pathologisch wotd aangemerkt (zoals hardlifvighieid, ambeien), gerelateerd aan het ontastingspatroon (Wright 1974, Gill 1979, Frexinos 1982). Deze sociaal-demografische variabelen worden eveneens in dit deelonderzoek betrokken.

\subsection{Opzet en uitvoering van het onderzoek}

\subsubsection{De dagboekmethode}

Inzicht in het normale defecatiepatroon wordt niet zonder meer verkregen door een aantal mensen daar vragen over te stellen. Wanneer het lichamelijke functioneren als onproblematisch wordt ervaren, is het aannemelijk dat de stoelgang passeert in de marge van het bewustzijn: men staat er niet of nauwelijks bij stil, als gezonde levend "in de stilte der organen" ("la vie dans le silence des organes", Leriche, 1936), 
Men bekijkt niet of niet altijd de prodlukten van de eigen stoelgang (Gill, 1979). Van het eigen defecatiepatroon blijkt niet iedereen zich expliciet en tot in details bewust. Manning e.a. (1977) stelden een discrepantie vast tussen antwoorden van respondenten op vragen omtrent de frequentie van hun stoelgang, en de feitelijke gang van zaken zoals vastgesteld met behulp van de dagboekmethode.

Ter bepaling van kenmerken van defecatiepatronen werd in dit deelonderzoek eveneens gekozen voor de dagboekmethode. Dagboeken werden ontworpen waarin respondenten gedurende veertien dagen de toiletgang konden bijhouden. Per dag was een tweezijdig te gebruiken formulier beschikbaar. De gevraagde informatie kon geregistreerd worden vanaf 6.00 uur "s morgens tot $2.00 \mathrm{uur}$ 's nachts; eventuele toiletverrichtingen tussen 2.00 en 6.00 uur werden bij 2.00 uur bijgeschreven. De dagboekbladen hadden een dusdanige indeling, dat gevragagde informatie per half uur kon worden genoteerd (zie Bijlage 3.1).

\subsubsection{Operationaliseren van de variabelen}

Informatie aangaande de afhankelijke variabelen werd verkregen met behulp van de dagboeken. De achterliggende gedachte is dat in onze samenleving over het algemeen overeenstemming bestaat tussen feiten, gebeurtenissen enzovoort, en de perceptie ervan en vervolgens de rapportage erover door de betreffende personen.

\section{De frequentie van de stoelgang}

De respondenten werd gevraagd iedere voorkomende stoelgang te noteren op het tijdstip waarop deze plaatsvond. Aldus kon het aantal ontlastingen in zijn totaliteit alsook per subgroep worden berekend, namelijk over de 14 registratiedagen (= variabele 1). Van de ontlastingen was vervolgens bekend op welke van de 14 dagen deze had plaatsgehad. Tenslotte is ook van de ontlastingen bekend of het een eerste dan wel een tweede of volgende stoelgang per dag betrof (variabele 2).

\section{Hoedanigheden van de faeces}

De hoeveelheid faeces per stoelgang (variabele 3 ) werd gemeten door te vragen naar de beoordeling ervan door de persoon zelf, die daarbij kon beschikken over de beoordelingsmogelijkheden: weinig, normaal en veel. Problematisch bij deze werkwijze is dat het normaalbegrip wordt gehanteerd en overgelaten aan de subjectieve beoordeling door de respondent zelf, terwijl het normale van het "normale defecatiepatroon' zou moeten blijken uit de via de dagboeken verzamelde data. Echter, het normale van de hoeveetheid faeces per stoelgang refereert aan de voor het individu gemiddeld meest gebruikelijke hoeveelheid. In dit geval benadert 'normaal' de betekenis van normaal zoals gebruikt voor het normale defecatiepatroon: het gebruikelijke, het meest voorkomende.

Overigens doet zich bij de beoordeling van de hoeveelheid faeces een praktisch probleem voor, namelijk bij bezitters van diepspoelwc's. De beoordeling van niet of slechts gedeeltelijk zichtbare faeces berust daarbij grotendeels op subjectieve beoordeling. Deelnemers aan het onderzoek rapporteerden echter dit niet als onbetrouwbaar ervaren te hebben - een indruk die overigens bevestigd wordt door het onderzoek van Van der Kooij (1987). 
Tensllotte kan, ondanks de bezwaren die kleven aan deze zelfbeoordeling door respondenten, worden vastgesteld dat deze werkwijze verkieslijker, in de zin van praktisch beter uitvoerbaar, is dan het objectief wegen van elke ontlasting.

De vorm van de ontlasting (variabele 4) werd per stoelgang vastgesteld door de respondent te vragen dit eveneens zelf te beoordelen, namelijk aan de hand van de kwalificaties: brijig, hoop en keutel-/knikkervormig. Aan deze zelfbeoordeling kleven dezelfde bezwaren van subjectiviteit als hierboven vermeld met betrekking tot de beoordeling van de hoeveelheid.

Behalve de vorm werd per stoelgang eveneens het aspect van de faeces vastgesteld; ook dit werd door de respondent zelf beoordeeld en in her dagboek geregistreerd aan de hand van de beoordelingscategorieèn: zacht/dun, normaal en hard/dik. Gaandeweg het onderzoek werd echter vastgesteld dat vorm en aspect uiteraard samenhangen ( $\mathrm{r}=$ $.44 ; \mathrm{p}=.000$ ): ontlastingen die als zacht/dun worden gekarakteriseerd worden over het algemeen ook als brijig beoordeeld; keutel- of knikkervormige faeces worden over het algemeen hard/dik gevonden. De hoedanigheid "consistentie', die met het oog op eenduidigheid aanvankelijk was gesplitst in de begrippen vorm en aspect, wordt in dit deelonderzoek derhalve samengevat in: 'vorm' van de faeces.

Informatie betreffende de kleur van de ontlasting werd aan de participanten niet gevraagd. Indien de kleur van de ontlasting op manifeste wijze afwijkt van het algemeen gangbare, hoort de persoon niet in deze steekproef thuis. Bovendien is er, uit praktische overwegingen, van afgezien naar tinten van bruin te vragen.

Omtrent de geur van de ontlasting werd eveneens geen informatie per afzonderlijke stoelgang gevraagd. Beoordeling van de geur kon, samenvattend per dag, in de dagboeken worden geregistreerd. In de enquête die het dagboek vergezelde werd gevraagd of de respondent de ontlasting doorgaans vond stinken. Als belevingsdeterminant werd deze variabele verder betrokken in de verslaglegging omtrent 'Determinanten van beleving van de stoelgang in een gezonde populatie' (hoofdstuk 4).

\section{De tijdsaspecten}

Inzicht in het tijdstip waarop elke ontlasting plaatsvond (variabele 5) werd verkregen doordat de stoelgang werd genoteerd in het genoemde urenschema in de dagboekformulieren.

De participanten was gevraagd per stoelgang de dua te noteren (variabele 6), gemeten vanaf het betreden van de toiletruimte tot en met de afsluitende hygiënische handelingen, afgerond tot op hele minuten.

Eveneens was gevraagd per stoelgang te noteren of, en zo ja hoe lang, de stoelgang was uitgesteld, eveneens afgerond tot op hele minuten. Aldus werd inzicht verkregen in het kenmerk: 'sitstel' (variabele 7) van het defecatiepatroon.

De regelmaat waarin, of wel de sfabiliteit per persoon waarmee bepaalde kenmerken van het ontlastingspatroon worden vastgesteld, zoals frequentie, duur, hoeveel heid, vorm, kon vervolgens worden berekend aan de hand van de informatie door de respondenten op de hierboven beschreven wijze geregistreerd.

\section{De plats}

Aan de plaats van de stoelgang werd in dit deelonderzoek voorbijgegaan. Dit kenmerk 
van het normale defecatiepatroon werd niet bij de opzet van het onderzoek betrokken vanwege de nodige beperking. De hoeveelheid informatie, via dagboeken gevraagd, dient niet alleen woor de participanten maar ook voor de onderzoeker zelf owerzichteljk te blifver.

Behalwe de ontlasting werd ook de urinelozing wel geregistreerd, matr niet in deze rapportage betrokken.

Informatie omtrent de onafhankelijke wariabelen werd ingewonnen via de enquêtes die de dagboeken begeleidden. Leefijd en geslacht worden als variabelen in de verdere versilalegging betrokken.

Dè sociale herkomst, waromtrent eveneens vanuit de enquêtes informatie werd ingewonmen, lijkt, gezien de kenmerken van de onderzoekspopulatie (cf. 3.5.3), niet in aanmerking te komen voor nadere specificatie of differentiatie van het ontlastingspatroon. De sociale klasse word derhalve niet als aparte onafhankelijke variabele opgevoerd.

Het zogenoemde "klein", dat wil. zeggen sub-pathologisch lichamelijk, ongemak werd eveneens geregistreerd met behulp van de begeleidende enquêtes. Als een van de "determinanten van beleving van de stoelgang" zal over deze variabele worden gerapporteerd in hoofdstuk 4.

\subsubsection{De onderzoekspopulatie}

De onderzoekspopulatie kwam tot stand met behulp wan de "sneeuwbal-methode". Enkele personen, woonachtig central in Nederland allsook in het zuiden, werd verzocht als respondent atan het onderzoek deel te nemen. Deze vroegen vervolgens de medewerking van een aantal andere personen. Van dezen gingen sommigen werder en verkregen de medewerking van nog andere geinteresseerden. Aldus werd, in de hoop 100 bruikbare dagboeken te verwerven, een onderzoeksgroep benaderd van in total 135 personen. Van dezen was bij voorbaat bekend dat zij twee karakteristieken gemeenschappelijk hadden: de deelnemers kenden allen iemand werkzaam in de gezondheidszorg en/of in het hoger onderwijs, én zij leden niet aan manifeste ziekten, gebreken of handicaps - hetgeen een woorwaarde was bij recrutering van de proefpersonen.

Degenen die voor deelname aan het onderzoek in anmerking kwamen, werden telefonisch benaderd. De bedoeling van het onderzoek werd uiteengezet. Ook werd uitgelegd wat van de respondenten werd verwacht. Wannees men deelname had toegezegd. werden de dagboekformulieren toegezonden, alsmede een enquêtelijist waarin werd gevralagd nat verschillende aspecten wan toiletgedrag, -gewoonten en -gebruiken, verder ook de VOEG-lijst (Vragen Over Erwaren Gezondheid), een instructie en een retourenvelop. 
De respons was als volgt:

\section{5 exemplaren verstrekt}

33 niet terug ontvangen

12 exemplaren onbruikbaar, namelijk:

- 8 dagboeken onvolledig bijgehouden

- 2 dagboeken gedeeltelijk teruggestuurd

- 1 bijbehorende enquête niet terug ontvangen

- 1 dagboek niet serieus genomen.

90 dagboeken werden dus opgenomen in de analyse.

Het voordeel van de hierboven beschreven werkwijze was, dat in de populatie slechts respondenten konden worden opgenomen, die deelname aan het onderzoek hadden toegezegd. In feite heeft slechts éen respondent bij nader inzien van deelname afgezien; deze droeg de onderzoeksformulieren over aan een huisgenoot.

Daarentegen bleek het met deze methode niet mogelijk enige controle, indien gewenst, uit te oefenen op de samenstelling van de onderzoeksgroep. Deelnemers aan het onderzoek benaderden potentiële deelnemers, die weer potentiële deelnemers benaderden. Dit resulteerde onder meer in het feit dat geen rappel aan de respondenten werd toegezonden.

De respons bleek in belangrijke mate negatief beïnwloed door een staking van de posterijen (november - december 1983): retourenveloppen bereikten ons niet omdat die in de ontstane verwarring bij de respondenten thuis of misschien ook in de verschillende postkantoren verloren gingen.

De onderzoekspopulatie waarvan ogenschijnlijk volledige gegevens werden verkregen, bestond uit 90 respondenten. Van dezen werden de dagboeken beoordeeld op het consequent volledig bijhouden ervan gedurende de gevraagde veertien dagen.

Uit Tabel 3.2, waarin enkele kenmerken van de onderzoeksgroep zijn opgenomen, blijkt dat de respondenten globaal genomen uit het 'brede maatschappelijke midden' afkomstig zijn, hetgeen bij onderzoek naar een als 'nomaal' ervaren gedragspatroon mag gelden als een wijze van "convenient sampling".

Van de respondenten waren er 10 jonger dan 20 en 17 ouder dan 60 jaar, preciexe leeftijden waren niet gevraagd.

De kenmerken van de populatie die niet in Tabel 3.2 zijn weergegewen, ontbreken daarin hetzij ondat zij nauwelijks kenmerkend zijn (het medicijngebruik bijvoorbeeld blijkt te verwaarlozen), hetzij ondat daarover in hoofdstuk 4 wordt gerapporteerd (bijvoorbeeld "klein", niet-pathologisch lichamelijk ongemak), hetzij omdat wellicht is nagelaten daaromtrent informatie in te wimnen.

\subsubsection{Dataverwerking}

Dataverzameling met behulp van bovengenoemde instrumenten resulteerde in een uitgebreid aantal variabelen, niet alle relevant voor deze partiële verslaglegging, maar wel van belang voor het onderzoek van de stoelgangbeleving: zie hoofdstuk 4 en Bijlage 4.1 . 
Geslacht en leeftijd

Wouwen 40 jaar 35

wouwem $>40$ jaar $\quad 23$

matnmen < 40 aar $\quad 19$

mannen $>40$ jaar

\section{Beroepen}

geschoold arbeider 3

lager employe 18

keinere zelfstandige 5

mildollowar employe 20

hogers beroepen 15

scholier/student. 18

husvroun 10
Type huishouden momenteel

gehuwdisamenwonend

ongehuwd alleenstaand

ongehuwd bil ouders

Totaal

Dataverzameling ten behoeve van het onderhavige deelonderzoek resulteerde in twee onderscheiden datamatrixen. Het normale defecatiepatroon kan namelijk beschreven worden vanuit twee verschillende invalshoeken: respectievelijk gerelateerd aan de stoelgang dan wel aan het individu. Het hier beschikbare onderzoeksmateriaal bestaat uit:

- 1468 ontlastingen, afkomstig van

-90 personen.

De onderzoeksresultaten zullen op drie manieren geordend worden.

- Waar het de frequentie van de stoelgang over de veertien dagen (var.1) alsook per dag (var.2) betreft, zijn de resultaten gerelateerd aan het totale aantal stoelgangen én aan het aantal respondenten (\$3.6.1 en \$3.6.2).

- Omtrent de overige vijf variabelen worden de resultaten, vanuit het humaan-biologisch perspectief in dit deelonderzoek, gerapporteerd op stoelgang-niveau $(\$ 3.6 .3$ $\mathrm{t} / \mathrm{m} 3.6 .7)$.

- Tenslotte wordt gerapporteerd over het regelmatigheidsaspect van de stoelgang, ofwell de stabiliteit per persoon wat betreft bepaalde kenmerken van het patroon. De regelmatigheid, die in feite betrekking heeft op alle voorafgaande variabelen, zal, op persoonsniveau, per variabele afzonderlijk worden berekend $(\$ 3.8)$.

\subsection{Onderzoeksresultaten: het defecatiepatroon gebaseerd op gegevens omtrent de stoelgang}

De kenmerken van het defecatiepatroon bleken, wat de variabelen afzonderlijk, niet in onderlinge samenhang, betreft, als volgt. 


\subsubsection{De frequentie}

Het totale aantal ontlastingen geregistreerd over de 14 dagen, is voor de hele populatie alsook voor de subgroepen weergegeven in Tabel 3.3.

Tabel 3.3 Ontlastingen: totale aantal over 14 dagen

\begin{tabular}{lrrrrr}
\hline & \multicolumn{2}{c}{ mannen } & \multicolumn{2}{c}{ vrouwen } & Totad \\
& $<40$ & $>40$ & $<40$ & $>40$ & \\
Aantal ontlastingen & 326 & 225 & 582 & 335 & 1468 \\
resp. $n=$ & 19 & 13 & 35 & 23 & 90 \\
M & 17.2 & 17.3 & 16.6 & 14.6 & 16.3 \\
$\mathrm{SD}$ & 9.5 & 3.9 & 5.9 & 2.7 & 6.0 \\
Me & 13.0 & 16.0 & 17.0 & 15.0 & 15.0 \\
Min & 7.0 & 13.0 & 6.0 & 9.0 & 6.0 \\
Max & 41.0 & 27.0 & 32.0 & 19.0 & 41.0 \\
\hline
\end{tabular}

$T=2.25,18.5 \mathrm{df}, p=0.04$

Het aantal ontlastingen per individu bedraagt gemiddeld 16.3 over twee weken, met een minimum van 6 en een maximum van 41 . De gemiddelden zijn het hoogst bij de jongere mannen (17.2) en de oudere mannen (17.3); het is significant het laagst bij de oudere vrouwen ten opzichte van de oudere mannen (14.6). Bij de de oudere vrouwen is de spreiding ook het geringst (2.7). Bij de jongere mannen daarentegen is die het hoogst (9.5); in deze groep komen respondenten voor met een betrekkelijk laag én met een hoog aantal ontlastingen (namelijk 7 , respectievelijk 41).

Het verschil tussen de gemiddelde aantallen ontlastingen bij de jongere en oudere vrouwen is miet significant. De $p$-waarde is echter van dien aard $(p=0.08)$ dat het verschil tussen de gemiddelden van beide subgroepen als tenminste opmerkelijk kan worden aangemerkt.

\subsubsection{Eerste, respectievelijk volgende stoelgangen per dag}

De gemiddelde frequentie van de stoelgang is, zoals ook volgt uit de gegevens betreffende variabele 1, 1.4 per dag, met een minimum van 0 en een maximum van 5 ontlastingen per dag.

Tabel 3.4 Percentages eerste, respectieveiljk volgende stoelgangen per dag

\begin{tabular}{lccccc} 
& \multicolumn{2}{c}{ mannen } & \multicolumn{2}{c}{ vrouwen } & Totaal \\
Keer: & $<40$ & $>40$ & $<40$ & $>40$ & \\
eerste & 67 & 76 & 68 & 83 & 73 \\
2de tim 5de & 33 & 24 & 32 & 17 & 27 \\
Total & $100 \%$ & $100 \%$ & $100 \%$ & $100 \%$ & $100 \%$ \\
& $(n=326)$ & $(n=225)$ & $(n=582)$ & $(n=335)$ & $(n=1468)$ \\
\hline
\end{tabular}

$x^{2}=31.7,3 d f, p=.001$ 
Uit tabe: 3.4 blijki dat de meeste stoelgangen, namelijk $73 \%$ van het totale aantal, eerste en dus enige stoelgangen per dag zijn; $27 \%$ betreft een weede tot en met een wiffe stoelgang per dag.

Bij de ouderen zijn de ontlastingen vaker een eerste (dus enige) stoelgang: $76 \%$ bij) de oudere mannen en $83 \%$ bij de oudere vrouwen. Bij de jongeren blijkt én op de drie ontlastingen juist een tweede of volgende stoelgang per dag.

Bij de jongere mannen werd, gemiddeld over 14 dagen, twee ontlastingen per dag als maximum geregistreerd.

\subsubsection{Hoeveelheid}

De hoeveelheid faeces per stoelgang werd beoordeeld zoals weergegeven in Tabel 3.5 .

Uit tabel 3.5 blijkt dat de meeste ontlastingen, namelijk $65 \%$ van het totale aantal. "normaal" van hoeveelheid worden beoordeeld. Bij de ontlastingen van de jongeren blijkt dit minder het geval dan bij die van de ouderen.

Bij de groep jonger dan 40 jaar wordt van ruim de helft van de ontlastingen de hoeveetheid als normal beoordeeld ( $56 \%$ van de ontlastingen van de jongere vrouwen, $58 \%$ van die van de jongere mannen). Bij de ouderen wordt van drie van de vier ontlastingen de hoeveelheild als normaal beoordeeld.

De beoordleling "weinig" bij de hoeveelheid faeces van de jongeren betreft $34 \%$ van de ontlastingen van de jongere vrouwen, $28 \%$ van die van de jongere mannen. Deze laatsten hebben echter ook het hoogste percentage 'veel' als beoordeling (14\%).

Gemiddeld wordt, op een driepuntsschaal (waarbij 1 = weinig en 3 = veel), de ontlasting als 1.9 beoordeeld. De jongere mannen en jongere vrouwen beoordelen de hoeveelheid van de ontlasting het meest uiteenlopend. De jongere vrouwen scoren, gemiddeld over 14 dagen, het laagst én het hoogst (namelijk 1.4 respectievelijk 3.0).

Tabel 3.5 Hoeveeheid faeces per stoelgang, in percentages

$<40^{\text {mannen }}>40 \quad<40^{\text {vrouwen }}>40 \quad$ Thotaal

Hoveverheid:

$\begin{array}{lccccc}\text { Woinig } & 28 & 14 & 34 & 18 & 26 \\ \text { Normat } & 58 & 79 & 56 & 77 & 65 \\ \text { Veel } & 14 & 7 & 10 & 5 & 9 \\ & & & & & 100 \% \\ \text { Total } & 100 \% & 100 \% & 100 \% & 100 \% & (n=1468)\end{array}$

$x^{2}=75,1,6 \mathrm{dr}, \mathrm{p}=.001$

\subsubsection{Vorm}

De vorm vin de ontlasting werd beoondeeld zoals weergegeven in Tabel 3.6.

Over het totale aantal ontlastingen wordt het merendeel (46\%) beoordeeld als "keutel-/knikkervormig"; een relatief gering percentage (17\%) wordt 'brijig' bevonden.

De ontlastingen van de vrouwen worden voor het merendeel als keutel-/knikkervor- 
mig beoordeeld, namelijk 50\% van die van de oudere en $61 \%$ van de ontlastingen van de jongere vrouwen. De ontlastingen van de mannen worden voor ruim de helft als hoop beoordeeld, namelijk $52 \%$ van de ontlastingen van de jongere en $57 \%$ van die van de oudlere mannen. Het "normale' van het defecatiepatroon, opgevat als het meest vóórkomende, betekent voor de mannen een hoopvormige ontlasting, voor de vrouwen keutel-/knikkervormige.

Op een driepuntsschaal (waarbij $1=$ brijig en $3=$ keutel- $/$ knikkervormig) werd de faeces gemiddeld als 2.3 beoordeeld. Gemiddeld seoren de mannen lager $(2.1)$ dan met name de jongere vrouwen (2.5). De minimumscore, over 14 dagen gemiddeld, werd geregistreerd bij de oudere mannen (1.0), de maximumscore $(3.0)$ bij de jongere vrouwen.

Tabel 3.6 Vorm van de faeces per stoelgang, in percentages

\begin{tabular}{lccccc} 
& \multicolumn{2}{c}{ mannen } & \multicolumn{2}{c}{ vrouwen } & Totaall \\
& $\left\langle 40^{-}>40\right.$ & $<40$ & $>40$ & \\
Vorm: & & & & & \\
Bijig & 21 & 16 & 11 & 23 & 17 \\
Hoop & 52 & 57 & 28 & 27 & 37 \\
Keutel-knikkervormig & 27 & 27 & 61 & 50 & 46 \\
Totaal & $100 \%$ & $100 \%$ & $100 \%$ & $100 \%$ & $100 \%$ \\
& $(n=326)$ & $(n=225)$ & $(n=582)$ & $(n=335)$ & $(n=1468)$ \\
\end{tabular}

$x^{2}=159.7,6 d f_{1} p=.001$

\subsubsection{Tijdstip}

De ontlastingen konden door de respondenten worden genoteerd vanaf 6.00 uur 's morgens tot 2.00 uur 's nachts. Eventuele stoelgang in de nachtelijke uren kon na 2.00 uur worden bijgeschreven. Slechts $0.8 \%$ van de geregistreerde ontlastingen had plaats tussen 2.00 en 6.00 uur. In de weergaven van het 24-uurs defecaticpatroon (voor de hele populatie als voor de subgroepen, of. Fig. $3.1 \mathrm{t} / \mathrm{m} \mathrm{3.3)} \mathrm{werden} \mathrm{deze} \mathrm{niet} \mathrm{apart}$ opgenomen.

De gemiddelde stoelgang vindt plaats om 12.55 uur (sd $=4.45$ uur). De stoelgang vindt blijkbaar overwegend 's morgens plaats, tussen 6.00 en 10.00 uur, met een duidelijke top tussen $8.00-9.00$ uur. Rond 13.00 uur en ook tussen 17.00 en 19.00 uur is er eveneens een - zij het geringere - toename van defecaties. Nadien neemt de stoelgang in de avonduren af.

Over vier ongeveer gelijke dagdelen verdeeld, worden ontlastingen geregistreerd zoals aangegeven in Tabel 3.7. Ook uit deze tabel blijkt dat de meeste ontlastingen worden geregistreerd in de ochtenduren. In het totaal vinden twee op de drie stoelgangen plaats voor 14.00 uur.

Vrouwen blijken, wat de stoelgang in de ochienduren betreft, een frequentie te registreren van iets boven her gemiddelde. Mannen blijven iets beneden het gemiddelde. voor ouderen blijkt de top in de defecatiecurve vroeger te liggen dan voor jongeren. 
$\%$ defecatie

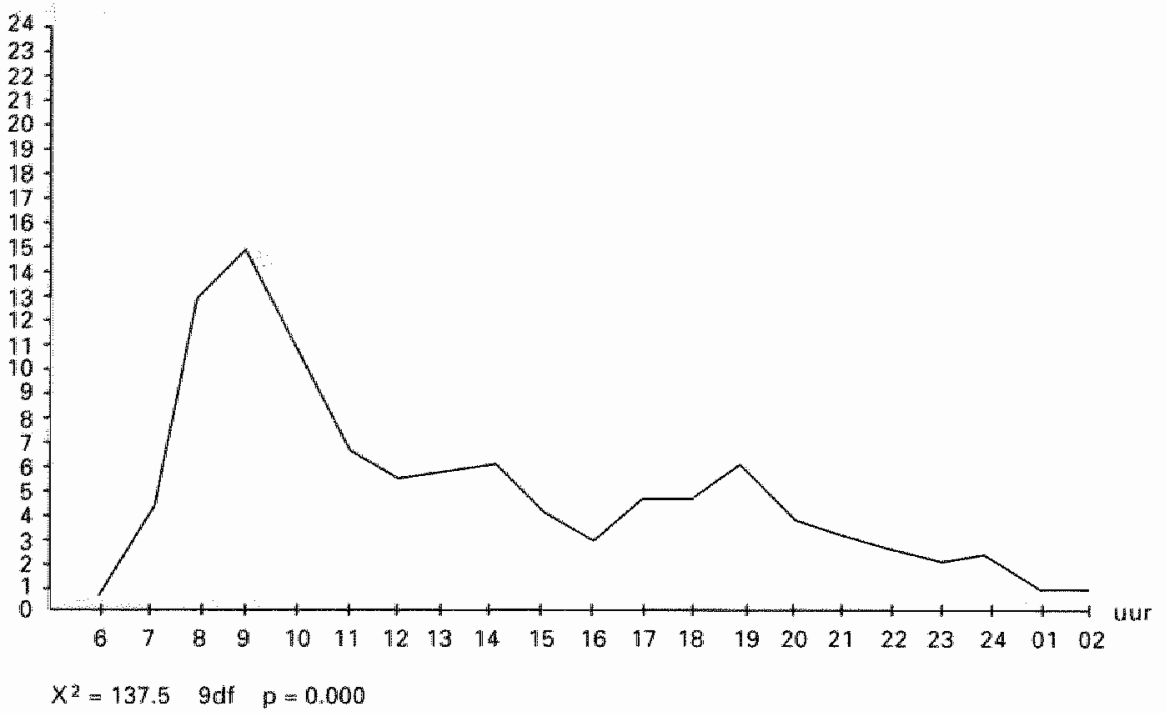

Fig. 3.1 24-uurs defecatiepatroon: hele populatie

\section{$\%$ defiecatie}

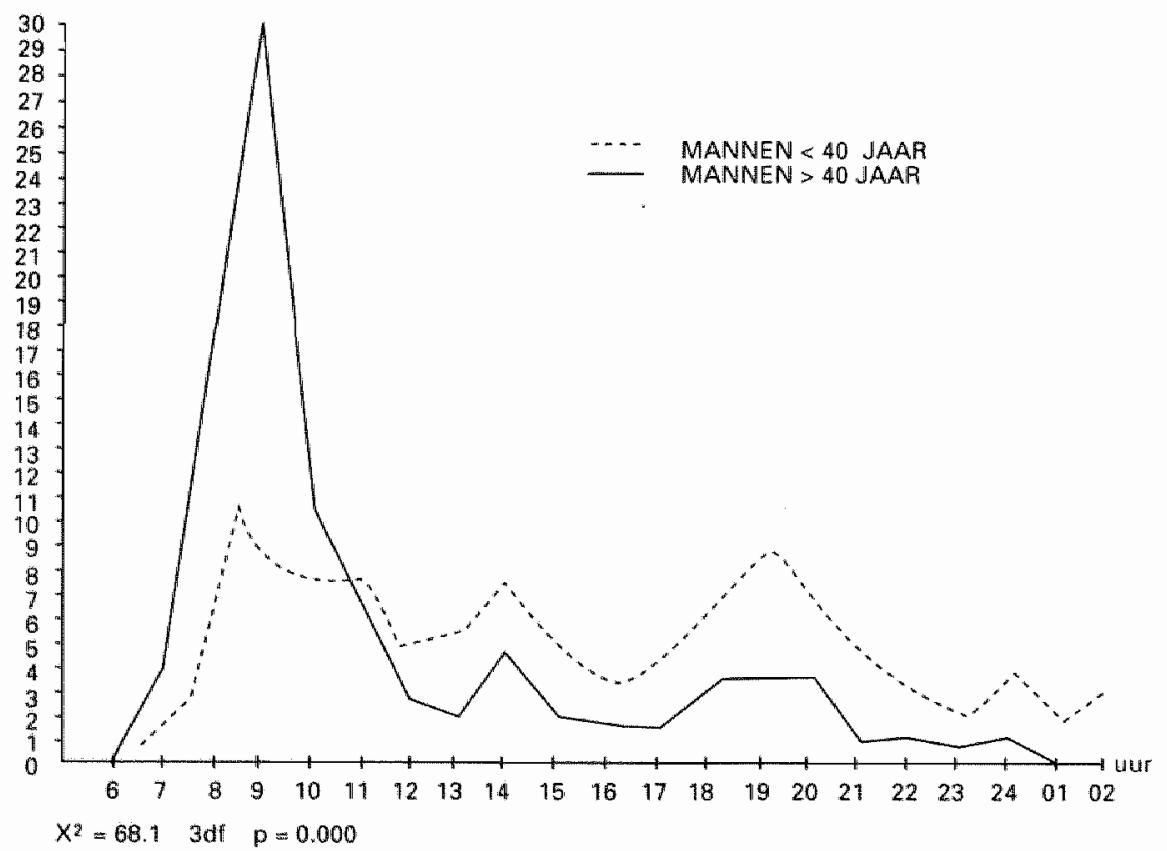

Fig. 3.2 24-uurs defecatiepatroon van jongere en oudere mannen 


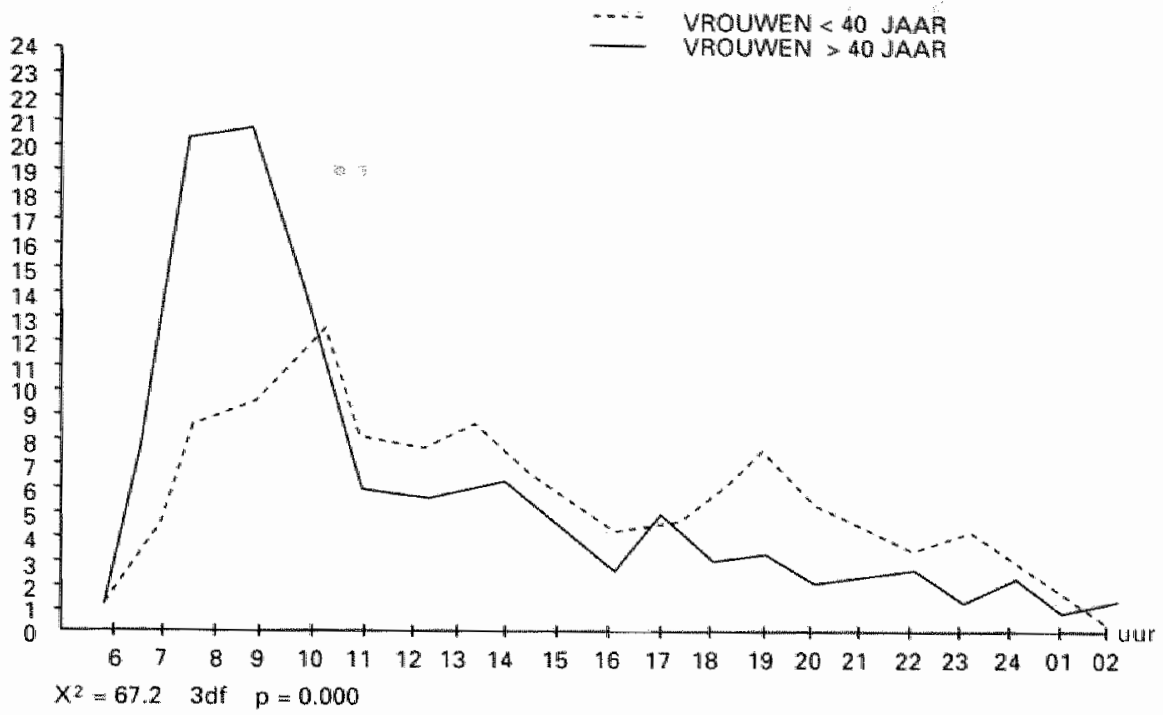

Fig. 3.3 24-uurs defecatiepatroon van jongere en oudere vrouwen

Tabel 3.7 Percentages ontlastingen per dagdeel, per subgroep

$<40^{\text {mannen }}>40^{\text {vrouwen }}<40^{\text {Totaal }}$

Tijdstippen

van: tot:

6.00-10.00

$10.30-14.00$

$14.30-18.00$

$18.30-2.00$

$<40>40$

$<40>40$

Totaal

Tolaal

$\begin{array}{rr}28 & 62 \\ 24 & 17 \\ 20 & 9 \\ 28 & 12\end{array}$

$\begin{array}{ll}33 & 60 \\ 27 & 18 \\ 16 & 11 \\ 24 & 11\end{array}$

42

$9 \quad 16$

24

$\begin{array}{clllll}\text { Tolaal } & 100 \% & 100 \% & 100 \% & 100 \% & 100 \% \\ & (n=326) & (n=225) & (n=582) & (n=335) & (n=1468)\end{array}$

$x^{2}=1375$ gaf $p=0.001$

Een belangrijke bijdrage in de ochtendpiek van de curve blijkl geleverd te worden door de stoelgangen van de respondenten ouder dan 40 jaar. De groep jonger dan 40 blijkt in de ochtenduren beduidend minder frequent nar de wo te gaan; door de rest van de dag blijft deze categorie iets boven het gemiddelde. Men kan stellen dat de stoelgang bij de respondenten boven de 40 in belangrijke mate 's morgens plaatsvindt, terwijl bij de groep onder de 40 de defecatie meer gespreid over de gehele dag plaatsvindt $\left.\mathrm{X}^{2}=133, \mathrm{p}=0.000\right)$. 
Gemiddeld ontasten oudere mannen zich het vroegst (11.05 uur), jongere mannen het latst (14.35 uwr). Over da 14 dagen gemiddeld wordt het vroegste tijdstip genoteerd in de groep oudere vrouwen (7.50 uur), het laatste tijdstip bij de jongere vrouwen (18.25 uur).

\subsubsection{Duwr}

Van de 1468 stoelgangen werd in 242 gevallen ( $16 \%$ ) geen opgave gedaan omtrent de duur. Büj de beschrijuing van de variabele 'duur' werden deze ontlastingen als missing buiten beschouwing geliaten. De duur van de overige 1226 stoelgangen bleek zoals weergegeven in Tabel 3.8 .

Tabel 3.8 Percentages duur van de stoelgang in minuten

\begin{tabular}{lccccc} 
& \multicolumn{2}{c}{ mannen } & \multicolumn{2}{c}{ vrouwen } & Totaal \\
& $<40$ & $>40$ & $<40$ & $>40$ & \\
Minuten: & & & & & \\
$1-4$ & 32 & 71 & 82 & 84 & 70 \\
$5-9$ & 37 & 21 & 16 & 15 & 21 \\
$10-14$ & 24 & 7 & 1 & 0.7 & 7 \\
$15-24$ & 7 & 1 & - & 0.3 & 2 \\
Totaal & $100 \%$ & $100 \%$ & $100 \%$ & $100 \%$ & $100 \%$ \\
& $(n=275)$ & $(n=194)$ & $(n=517)$ & $(n=240)$ & $(n=1226)$ \\
no. & 51 & 31 & 65 & 95 & 242 \\
Totaal & 326 & 225 & 582 & 335 & 1468 \\
\hline
\end{tabular}

$x^{2}=243.63$ df $p=.001$

De meeste stoelgangen, namelijk $70 \%$ van het totale aantal, duren betrekkelijk kort ( 1 tot 4 minuten). Nog eens $21 \%$ wan de ontlastingen duurt 5 tot 9 minuten. $9 \%$ duurt langer dan 10 minuten. De gemiddelde stoelgang duurt 3.9 minuten $(\mathrm{sd}=3.0$ ); de langste duur van een stoelgang bedroeg 24 minuten.

Stoelgangen wan de jongere mannen duren beduidend langer. Bij de jongere en oudere vrouwen duren de meeste stoelgangen kort. Dit geldt, zij het relatief minder, ook voor de stoelgangen van de oudere mannen.

Op persoonsniveau beoordeeld, kan worden vastgesteld dat, over 14 dagen gemiddeld, mannen langer over de stoelgang doen dan vrouwen. Bij de mannen is ook de spreiding groter dan bij de vrouwen: de gemiddelde minimumduur ligt in de vier subgroepen tussen 1.0 en 1.9 minuten, maar de gemiddelde maximumdur is bij de mannen twee keer zo groot als bij de vrouwen, namelijk 10.2 en 10.9 bij de mannen jonger en ouder dan 40 jaar, respectievelijk 5.2 en 5.4 bij de overeenkonstige groepen vrouwen. Jongere mannen doen gemiddeld het langst, jongere vrouwen het kortst over de stoelgang (respectievelijk 5.4 en 3 minuten). 


\subsubsection{Uitstel}

De verdeling van al dan niet uitgestelde ontlastingen bleek als weergegeven in tabel 3.9 .

Tabel 3.9 Uitstel van de stoelgang, procentueel

\begin{tabular}{|c|c|c|c|c|c|}
\hline & $=: \mathrm{ma}$ & & & wen & Total \\
\hline & $<40$ & $>40$ & $<40$ & $>40$ & \\
\hline Uinges & & & & & \\
\hline Wel & 10 & 4 & 10 & 4 & 8 \\
\hline Niet & 90 & 96 & 90 & 96 & 92 \\
\hline Totaal & $\begin{array}{l}100 \% \\
(n=326)\end{array}$ & $\begin{array}{l}100 \% \\
(n=225)\end{array}$ & $\begin{array}{l}100 \% \\
(n=582)\end{array}$ & $\begin{array}{l}100 \% \\
(n=335)\end{array}$ & $\begin{array}{l}100 \% \\
(n=1468)\end{array}$ \\
\hline
\end{tabular}

$x^{2}=22.1$ 3af $p .001$

Uit de tabel blijkt dat de stoelgang over het algemeen betrekkelijk zelden als uitgesteld wordt gerapporteerd. Van alle 1468 ontlastingen waren er $111(=8 \%)$ aangegeven als uitgesteld.

Bij de jongere mannen en vrouwen blijkt $10 \%$ van de defecaties uitgesteld; bij de oudere mannen en vrouwen slechts 4 procent.

De als uitgesteld geregistreerde stoelgangen waren gemiddeld 70 minuten uitgesteld (sd $=106.6 \mathrm{me}=30 \mathrm{~min}$.$) ; de kortst gerapporteerde tijd van uitstel bedragt 2$ minuten, de langst uitgestelde tijd is 10 uur. Andere lang uitgestelde defecaties betreffen drie en een half uur tot en met negen uur. Zes ontlastingen werden drie uur uitgesteld.

\subsection{Defecatiepatroon: samenhang van variabelen}

Na verworven inzicht in afzonderlijke kenmerken van het 'normale defecatiepatroon', rijst de vraag omtrent eventuele samenhang tussen deze kenmerken. Ter nadere vaststelling van eventuele structuren werd een factoranalyse uitgevoerd over de data van de stoelganggerelateerde matrix.

Van de acht benoemde humaan-biologische kenmerken van hel normale defecatiepatroon kwamen er drie niet in aanmerking voor opname als variabelen in de factoranalyse. "Frequentie' leende zich, vanwege de wijze waarop de informatie datromtrent in de matrix was opgenomen, niet voor die statistische bewerking. De variabele 'eerste, respectievelijk volgende stoelgang per dag' werd vanwege te verwachten logische artefacten buiten verdere analyse gelaten. Het aspect 'stabiliteit' werd eveneens buiten beschouwing gelaten vanwege de wijze waarop kennis daaromtrent was verkregen. De factoranalyse werd uitgevoerd op de vijf resterende variabelen, zowel over de gehele populatie (Tabel 3.10) als over de vier onderscheiden subgroepen (zie Bijlage 3.2). 
Tabel 3.10 Factorladingen op twee factoren, na varimaxratatie, van de stoelganggerelateerde datamatrix

Factor 1

Factor 2

Ontlastingen wan de hele populatie $(n=468)$

- Vorm

- Hoevee heid

68

- Tiostip

$-66$

- Duur

.63

- Uitatel

.01

$-.03$

$-.25$

.04

.32

.75

.66

Voor de totale populatie werd bij factoranalyse 49 procent van de variantie in de variabelen verklaard door twee factoren (Eigenvalue respectievelijk 1.29 en 1.15). Na rotatie volgens het varimaxcriterium bleken twee factoren als volgt te benoemen:

1. Een eerste dimensie waarop ontlastingen te ordenen zijn, geeft een combinatie weer van enkele ontlastingskenmerken, namelijk de eigenschappen 'later op de dag', "weinig" en 'keutel- $/$ knikkerachtige' ontlasting. Samengevat lijkt deze dimensie gekenmerkt door modaliteiten: ontlastingen zijn vroeger of later op de dag, met kenmerken betreffende hoeveelheid en vorm.

2. Een tweede dimensie is een combinatie van de kenmerken "uitstel" van de stoelgang en "cluur" van de ontlasting. Deze dimensie lijkt, samengevat, gekenmerkt door gedragsaspecten: de stoelgang is al dan niet uitgesteld en duurt - wellicht mede vanwege de zich inmiddels ophopende faeces - langer.

Beide factoren worden aangetroffen in elk van de onderscheiden subgroepen, zij het met onderlinge verschillen.

Factor 1 wordt bij de stoelgangen van de jongere vrouwen in dezelfde samenstelling aangetroffen als in de hele populatie. Bij de stoelgangen van de oudere vrouwen blijkt de variabele 'hoeveelheid' vervallen, bij die van de oudere mannen 'vorm'. Bij de ontlastingen wan de jongere mannen vervalt 'tijdstip", maar uitstel wordt eraan toegevoegd.

Factor 2 wordt in de vier subgroepen aangetroffen, bij de ontlastingen van de jongere mannen echter met toevoeging van de variabele 'tijdstip' (later op de dag), bij die van de oudere mannen van de variabele "vorm' (brijig), en bij de ontlastingen van de oudere vrouwen van 'hoeveelheid' (geringer). Bij de stoelgangen van de jongere vrouwen is de factor herken baar aanwezig, zij het - om hier niet relevante redenen - in omgekeerde richting (bij uitstel zou de stoelgang niet langer maar korter duren).

Berekening van Pearsons correlaties (waarvan de matrix is opgenomen als Bijlage 3.3) ondersteunt enerzijds deze patronenstructuur, terwijl anderzijds precisering werd aangebracht.

Voor factor 1 blijken relaties tussen tijdstip en hoeveelheid, tijdstip en vorm, en vorm en hoeveelheid van de faeces. Niet blijkt echter dat van de ontlastingen van oudere vrouwen de hoeveelheid faeces geringer wordt naarmate de stoelgang later op de dag plaatsvindt $(\mathrm{r}=.03, \mathrm{n} . \mathrm{s}$, ) De faeces $z i j n$ harder bij vrouwen, in tegenstelling tot mannen, 
naarmate de stoclgang later op de dag plaatswindt en ook naarmate de hoeveelleid faeces geringer is. De hoeveelheid faeces is groter bij ontlastingen van jongere viouwen naarmate het atantal ontlastingen per dag geringer is, bij oudere vromwen echter naarmate het aantal ontlistingen per dag groter is.

Voor factor 2 is duidelijk dat de stoelgang langer duurt als deze is uitgesteld. Dit werband blikt significant bij de ontlastingen van jongere en oudere mannen , echter niet bil die van de vrouwen.

\subsection{Stabiliteit per persoon van het defecatiepatroon}

Stabiliteit per persoon is het kenmerk van het ontlastingspatroon dat te maken heeft met regelmaat en voorspelbaarheid. Stabiel op persoonsniveau is het patroon dat in grote mate onveranderlijk, identiek aan zichzelf blijkt.

'Stabiliteit per persoon' heeft in tweeèrlei zin betrekking op kenmerken van het defecatiepatroon. Enerzijds kunnen tijdsaspecten van bet patroon worden beoordeeld op stabiliteit, namelijk de frequentie van de stoelgang $(\$ 3.8 .1)$. Anderzijds kan stabiliteit per persoon worden vastgesteld in het vórkomen van de hoedanigheden van de ontllasting, namelijk van de hoeveelheid en de vorm van de faeces, het tijdstip van de stoelgang gedurende de dag, de duur van de stoelgang en de duur wan het uitstel ervan $(\$ 3.8 .2 \mathrm{t} / \mathrm{m} 3.8 .6)$

Met betrekking tot variabele 2 zal de stabiliteit per persoon niet worden berekend. Aangetoond zou slechts worden dat volgende stoelgangen platsvinden ingeval deze zijn voorafgegaan door een eerdere (is eerste) stoelgang - hetgeen volstrekt duidelijk dus overbodig is.

Stabiliteit per persoon in de bovenbeschreven betekemis is een relatief begrip: het referentiepunt is het patroon van de eigen subgroep. Het oordeel over stabiliteit per persoon komt tot stand in relatie tot hetgeen in de onderscheiden subgroepen als gemiddelden of als 'standaardwarden' voor de onderscheiden kenmerken werd vastgesteld. Daarbij wordt een marge van min en plus $15 \%$ aangehouden. Dit betekent bijvoorbeeld dat iemand die de hoeveelheid van de faeces beoordeelt als "normaal" en wel mér dan $15 \%$ af wijkt van de gemiddelde score op "normaal "maar dat over de hele periode, beschouwd wordt als iemand met een stabiel persoonlijk patroon.

\subsubsection{Stabiliteit per persoon van de frequentie}

Het defecatiepatroon geeft perioden te zien waarin de stoelgang in regelmatig aaneen gesloten dagen plaatsvindt. Tabel 3.11 geeft informatie uit de persoonsgerelateerde datamatrix.

De langst aaneengesloten perioden betreffen voor de meesten (73\%) perioden van 6 tot 14 aaneengesloten dagen, en voor $42 \%$ van de respondenten perioden van 11 tot 14 aaneengesloten dagen met een of meer keren ontlasting per dag. Bij vier respondenten, allen in de categorie der jongeren, werden geen aneenges.loten dagen vastgesteld: het patroon bestaat uit afwisselend dagen zonder en een dag mell defecatie. Maar eveneens in de categorie beneden 40 jaar worden, in aaneengesloten perioden van 14 dagen, gemiddelden van 2.3 en 2.9 ontlastingen per dag gevonden. 
Tabel 3.11 Langst aaneengesloten perioden van dagen met een of meer ontlastingen

$<40^{\text {mannen }}>40^{\text {vrowwer }}<40^{2}>40$

Totaal

Aareengesloten dagen:

\begin{tabular}{lccccc}
11.14 & 7 & 11 & 10 & 10 & 38 \\
Totaal & 19 & 13 & 35 & 23 & 90 \\
\hline
\end{tabular}

$x^{2}=12.3$ 3d $p<0.01$

Inzake het aantal aaneengesloten dagen bliken er geen significante verschillen tussen mannen en wrouwen $\left(\mathrm{X}^{2}=4.09,2 \mathrm{df}, \mathrm{n} . \mathrm{s}\right.$.). Tussen de leeftijdsklassen echter bestaat een verschil: het ontlastingspatroon van de oudere respondenten vertoont meer langere aaneengesloten perioden $\left(\mathrm{X}^{2}=6.7,2 \mathrm{df}, \mathrm{p}<0.05\right)$. Oudere mannen blijken persoonlijk stabieler $(85 \%)$, jongere vrouwen persoonlijk onstabieler $(29 \%)$.

Stabiel per persoon is, wat de frequentie van de ontlasting betreft, het defecatiepatroon van de 38 respondenten ( $42 \%$ ) met (nagenoeg) dagelijkse stoelgang.

\subsubsection{Stabiliteit per persoon van de hoeveelheid faeces}

Gerelateerd aan de percentages weergegeven in Tabel 3.5 en met inachtneming van de marge van min en plus $15 \%$, blijken, wat de hoeveelheid faeces per stoelgang betreft, de beoordelingen persoonlijk stabiel zoals weergegeven in Tabel 3.12.

Tabel 3.12 Stabiliteit per persoon van de hoeveelheid faeces, persoonsgerelateerd $(n=90)$

$<40^{\text {mannen }}>40 \quad<40^{\text {vrowwen }}>40 \quad$ Total

Stabiel:

Personen

9

6

20

13

48

Totalal

19

$\$ 3$

35

23

90

$x^{2}=0.7$ dif n.s.

Ongeveer de helft $(53 \%)$ van de respondenten geeft blijk wan een persoonlijke stabiele beoordeling. In geen van de onderscheiden subgroepen overigens, beoordeelt men de hoeveetheid ontlasting per stoelgang stabieler dan in andere subgroepen.

\subsubsection{Stabiliteit per persoon van de vorm}

De beoordeling van de vorm wan de faeces blijkt, gerelateerd aan de percentages van de beoordelingen in Tabel 3.6, stabiel per persoon zoals weergegeven in Tabel 3.13 . 
Tabel 3.13 Stabilitelt per persoon van de vorm van de ontlasting. persoonsgerelateerd $(n=90)$

$<40^{\text {mannen }}>40^{\text {vrouwer }}<40^{>}>40 \quad$ Totaal

Stabiel:

Personen

Totaal

13

35

23

90

$x^{2}=2.6$ 3dt n.s.

Over de gehele lijn blijken velen, namelijk $81 \%$ van de respondenten, de vorm van de ontlasting stabiel te beoordelen.

In geen van de subgroepen beoordeelt men de vorm van de faeces op persoonsniveau stabieler dan in andere subgroepen.

\subsubsection{Stabiliteit per persoon met betrekking tot het tijdstip van de stoelgang gedurende dle dag}

Beoordeling van de stabiliteit per persoon met betrekking tot het tijdstip van de stoelgang gebeurde in relatie tot de percentages weergegeven in Tabel 3.7. Stabiel per persoon blijken de ontlastingstijdstippen van de respondenten zoals weergegeven in Tabel 3.14.

Tabel 3.14 Stabiliteit per persoon van het tijdstip van de stoelgang, persoonsgerelateerd $(n=90)$

\begin{tabular}{|c|c|c|c|c|c|}
\hline & \multicolumn{2}{|c|}{ mannen } & \multicolumn{2}{|c|}{ vrouwen } & \multirow[t]{2}{*}{ Totad } \\
\hline & $<40$ & $>40$ & $<40$ & $>40$ & \\
\hline $\begin{array}{l}\text { Stabiel: } \\
\text { Personen }\end{array}$ & 16 & 9 & 26 & 20 & 71 \\
\hline Totaal & 19 & 13 & 35 & 23 & 90 \\
\hline
\end{tabular}

$x^{2}=3.4$ 3at n.s.

Stabiel per persoon wat her tijdstip van de stoelgang betreft blijkt $79 \%$ van de respondenten.

Persoonlijke stabiliteit in tijdstipy is in geen van de subgroepen opmerkelijk groter dan in de andere subgroepen.

\subsubsection{Stabiliteit per persoon van de duur van de stoelgang}

De stabiliteit per persoon met betrekking tot de duur per stoelgang werd beoordeeld in relatie tot de percentages weergegeven in Tabel 3.8. De duur van de stoelgang bleck, over de onderscheiden subgroepen, stabiel op persoonsniveau zoals weergegeven in Tabel 3.15 . 
Tabel 3.15 Stabiliteilt per persoon van de duur van de stoelgang, persoonsgerelateerd $(n=90)$

\begin{tabular}{|c|c|c|c|c|c|}
\hline \multirow[b]{3}{*}{ Slablel: } & \multicolumn{2}{|c|}{ manen } & \multicolumn{2}{|c|}{ urouwen } & \multirow[t]{2}{*}{ Tolaal } \\
\hline & $<40$ & $>40$ & $<40$ & $<40$ & \\
\hline & & & 33 & 14 & 66 \\
\hline Totaal & 19 & 13 & 35 & 23 & 90 \\
\hline
\end{tabular}

Leefhidsgroepen: $x^{2}=2.2$, n.s. Geslacht: $x^{2}=19.4, p=0.001$

Wat de duur van de stoelgang betreft is het defecatiepatroon van de mannen duidelijk stabieler per persoon dan dat van de vrouwen $\left(\mathrm{X}^{2}=19.4, \mathrm{p}=0.000\right)$; bijna alle mannen (91\%) blijken een stabiele duur van de ontlasting te registreren, tegenover $64 \%$ van de vrouwen. Leeftijd blijkt hier niet van invloed.

\subsubsection{Stabiliteit per persoon van uitstel van de stoelgang}

Beoordeling van de stabiliteit per persoon van uitstel van de stoelgang vond plaats in relatie tot de percentages in Tabel 3.9. De stabiliteit per persoon van het uitstelgedrag bleek, voor de respondenten in de onderscheiden subgroepen, zoals weergegeven in Tabel 3.16 .

Tabel 3." 6 Stabiliteit van uitstell van de stoelgang, persoonsgerelateerd $(n=90)$

\begin{tabular}{lccccc} 
& \multicolumn{2}{c}{ mannen } & \multicolumn{2}{c}{ vrouwen } & Total \\
Stabiel: & $<40^{2}$ & $>0$ & $<40$ & $>40$ & \\
Personen & 3 & 1 & 5 & - & 9 \\
Total & 19 & 13 & 35 & 23 & 90 \\
\hline
\end{tabular}

Niet getoetst wegens te kleine aantallen

Stabiliteit per persoon in het uitstelgedrag wordt maar bij een beperkt aantal respondenten (10\%) geconstateerd. Ook in deze is tussen de subgroepen geen opmerkelijk verschil astontoonbsar.

Samenvattend geldt ten aanzien van humaan-biologische kenmerken van het defecatiepatroon dat "standaardwaarden' kunnen worden berekend, die klaarblijkelijk werschillen tussen onderscheiden subgroepen. Met betrekking tot die variabelen kunnen respondenten globaal genomen al dan niet stabiel per persoon scoren.

Stabiliteits-scores zijn op sommige variabelen hoger dan op andere. Relatief het minst stabiel per persoon blijkt het uitstelgedrag, waarop door $10 \%$ van de respondenten werd gescoord. Van de subgroep van oudere vrouwen toonde geen der respondenten persoonlijke stabiliteit op dit punt. 
Door de hele groep werd het meest stabiel per persoon gescoord op de vanabelen "vorm" (82\%) en "tijdstip" (79\%). Het hoogst per subgroep echter werd gescoord door de jongere mannen op de variabele 'duur' $(95 \%$, bij een stabiliteits-score van $73 \%$ voor de hele populatie).

Op subgroepniveau werd het meest stabiel per persoon geantwoond in de subgroepen van jongere mannen (gemiddeld $3.7^{\prime}$ 'stabiliteiten') en oudere mannen (gemiddeld 3.8), het minst in de groep vary jongere vrouwen en oudere vrouwen (gemiddeld respectievelijk 3.1 en 3.3). De verschillen tussen deze gemiddelden zijn overigens niet significant.

\subsection{Structuren van het normale defecatiepatroon}

Bovenbeschreven stabiliteitskenmerken van de individuen leiden tot de vraag of er structuur tussen deze kenmerken is te onderkennen. Deze wraag kan op twee punten beantwoord worden $(\$ 3.9 .1$ en 3.9 .2$)$.

3.9.1 Allereerst kan de vraag worden gesteld naar eventuele onderlinge samenhang tussen de scores op de verschillende variabelen. Tabel 3.17 geeft daaromtrent een overzicht.

Variabele 7, "uitstel', waarop de stabiliteitsscore (te) gering was, is niet opgenomen in deze tabel.

Tabel 3.17 Samenhang in overeenstemmingscoëfficiënten tussen de kenmerkende variabelen van het normale defecatiepatroon

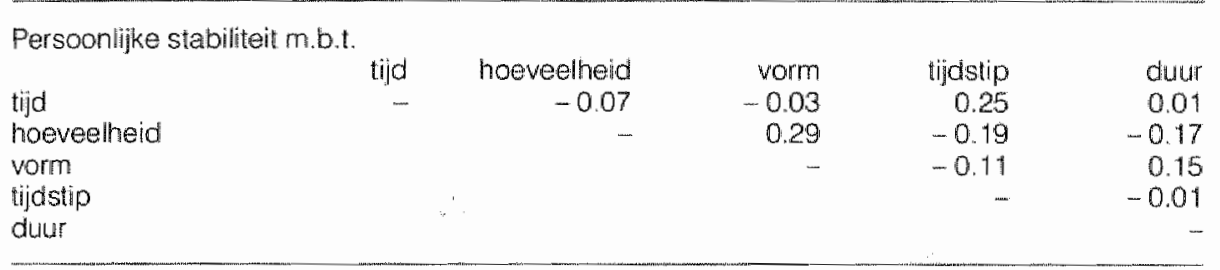

Tabel 3.17 toont geen significante relaties tussen verschillende variabelen; eventueel onderling verband of duidelijke interactie tussen de variabelen blijkt derhalve niet aantoonbaar.

3.9.2 Vervolgens is de vraag of de twee factoren die met betrekking tot de ontlastingen waren beschreven, ook herkenbaar zouden zijn op persoonlijk niveau. Met andere woorden: zijn de twee op stoelgangniveau gevonden dimensies herkenbaar op persoonsniveau als twee verschillende ontlastingspatronen?

Dit blijkt niet het geval. Variabelen die op stoelgangniveau met elkaar in verband staan, blijken op persoonsniveau niet aan elkaar gerelateerd. Uitgaande van de gevallen waarbij de individuen een stabiel patroon hebben, worden bij correlaties geen signifi. cante verbanden gevonden. Een voorbeeld kan dit verduidelijken. 
Tabel 3.18 Relatie tussen stabiliteiten op de kenmerken vorm en hoeveelheid van de ontiasting

\begin{tabular}{|c|c|c|c|c|}
\hline worm: & bring & hoop & Keutel & Totaal \\
\hline \multicolumn{5}{|c|}{ hoteveelheid: } \\
\hline Heing & 3 & 2 & 5 & 10 \\
\hline nonrnaal & 7 & 10 & 8 & 25 \\
\hline ved & 1 & 4 & 2 & 7 \\
\hline Totaal & 11 & 16 & 15 & 42 \\
\hline
\end{tabular}

$x^{2}=2.9$ 4di, nis.

Uit tabel 3.18 blijkt, met betrekking tot 42 respondenten die oppersoonsniveau "stabiel' scoorden op de beoordelingen van zowel de hoeveelheid als de vorm van de faeces, geen significant verband tussen beide variabelen.

Het persoonlijke 'normale' defecatiepatroon blijkt niet gestructureerd volgens de principes waarmee stoelgangen geordend kunnen worden. De uitscheiding is weliswaar een humaan-biologisch gegeven, het persoonlijke stoelgangpatroon is daarenboven duidelijk méer, althans anders dan een louter fysiologisch of humaan-biologisch proces.

\subsection{Samenvatting, discussie en conclusies}

In het deelonderzoek waarover hier wordt gerapporteerd, luidt de onderzoeksvraag: Welke zijn de kenmerken van het 'normale defecatiepatroon'?

Normaliteit wordt hier niet als het meest wenselijke, het meest ideale opgevat, maar in de betekenis van het meest voorkomend, het meest beantwoordend aan de normen die in dit onderzoek werden bepaald aan de hand van gemiddelden.

Met betrekking tot de geselecteerde humaan-biologische kenmerken van het defecatiepatroon kan het normale patroon getypeerd worden als volgt.

In relatie tot zowel de participanten in het onderzoek als tot de geregistreerde ontlastingen werd een stoelgangfrequentie vastgesteld van 1.4 stoelgang per dag. Van alle geregistreerde ontlastingen betreft $73 \%$ een cerste, dus enige, stoelgang per dag. De hoeveelheid faeces per stoelgang wordt in $65 \%$ van de gevallen als 'normaal' beoordeeld. Wat de worm betreft wordt $46 \%$ van de ontlastingen als 'keutel-/knikkervormig' beoordeeld. De gemiddelde stoelgang heeft plaats om 12.55 uur; twee van de drie ontlastingen vinden plaats vór 14.00 uur. De gemiddelde stoelgang duurt 3.9 minuten; van alle stoelgangen duurt $70 \%$ tussen 1 en 4 minuten.

De stabiliteit, die werd berekend op persoonsniveau, bleek voor sommige variabelen hoger dan voor andere. Door de hele groep werd het meest stabiel gescoord op de variabele 'vorm" ( $82 \%)$ en 'tijdstip' (79\%). Het minst stabiel per persoon blijkt men te scoren op de variabele 'uitstel' ( $10 \%)$.

Structuur tussen variabelen werd, wat de ontlastingen betreft, vastgesteld met behulp van factoranalyse. Twee factoren werden benoemd, als respectievelijk modaliteiten van 
de stoelgangen (vorm en hoeveetheid van de faeces en tjdstip van de stoelgang), en gedragsaspecten (uitstel en duur van de stoelgang).

De ontlastingen van de vier subgroepen varieren global genomen elk op andere wijzen op de twee onderscheiden factoren. Varianten ontstaan door wagvallen of toevoeging van meestal een variabele per factor.

De factoren, die gelden als ordeningsprincipen bij bestudering van ontastingen, worden niet teruggevonden op persoonsniveau: het individuele defecatiepatroon wordt blijkbaar niet alleen door humaan-biologische factoren beinvloed.

Kenmerken van de ontastingen werden beschreven voor de subgroepen ondersche:den naar geslacht en leeftijdsgroepen. Uitgaande van de varianten op de twee factoren, en gebaseerd op Pearsons correlaties, blijken deze kenmerken de volgende.

Het ontlastingspatroon van ouderen ( $>40$ jarr) vertoont de volgende kenmerken.

In het algemeen:

- een regelmatige ontlastingsfrequentie, namelijk van 1 a 2 maal per dag:

- in relatief lang aaneengesloten perioden, namelijk 11 tot 14 dagen;

- waarin met name de oudere mannen beduidend stabieler blijken dan de anderen.

Met betrekking tot de ontllastingen gekenmerkt naar modaliteiten (factor 1 ):

- een vast moment voor de stoelgang, namelijk in de ochtenduren;

- nomale hoeveelheid van de faeces.

Gekenmerkt door gedragsaspecten (factor 2):

- kortere duur van de toiletgang dan bij de jongeren;

- minder uilstelgedrag dan bij jongeren.

Kortom: het defecatiepatroon van de gezonde oudere blijkt te worden gekenmerkt door regelmaat.

Tegenover dit tamelijk evenwichtige beeld van het ontlastingspatroon bij de oudere, wordt het patroon bij de jongere (dan 40 jaar) veeleer gekenmerkt door onregeimatig. heid. De frequentie van de ontlasting is, vergeleken met die van de ouderen, deals lager (1 à 4 maal per week), maar ook deels hoger ( $\geq 3$ mal deags). Regelmat in aaneengesloten perioden wordt aanmerkelijk minder vastgesteld. De ontlasting vind plaats op uiteenlopende momenten gedurende de dag en word gemakkelijk uitgesteld. Regelmati wordt niet geconstateerd in de hoeveelheid faeces, die vaak veel is maar ook vaak weinig, noch in vorm: de faeces is vaak hard en dik, maar ook vaak zacht en dun.

Differentiatie blijkt er miet alleen te bestaan in het ontlastiugspatroon tussen jongeren en ouderen, mar ook tussen mannen en wouwen:

Met betrekking tot de modaliteiten van de ontlastingen (factor 1):

Ten aanzien van de variabele "tijdstip":

- de "defecatie-piek" ligt bij mannen 's morgens een uur later dan bij vrouwen;

- naarmate de stoelgang later op de dag plaatsvindt, is de hoeveelheid faeces geringer bij mannen en bij jongere vrowwen. 
Ten aanzien van de variabele "hoeveelheid":

- de hoeveelheid ontlasting per stoelgang is bij mannen over het algemeen groter dan bij vrouwen:

- de hoeveeheid faeces is groter bij jongere vrouwen naarmate het aantal ontlastingen geringer is, bij oudere vrouwen echter zijn de latere ontiastingen groter naarmate het aantal ontlastingen toeneemt.

Ten aanzien van de variabele 'vorm':

- de vorm van de faeces is bij mannen vaak brijig en hoopvormig, bij vrouwen eerder hard en knikkervormig;

- bij vrouwen zijn de faeces harder naarmate de stoelgang later op de dag plaats vindt;

- bij vrouwen zijn de faeces harder naarmate de hoeveelheid geringer is.

Gekenmerkt door gedragsaspecten (factor 2):

- mannen stellen later op de dag de stoelgang meer uit;

- de duur van de toiletgang is bij mannen langer dan bij vrouwen;

- bij mannen duurt de stoelgang langer naarmate deze meer is uitgesteld;

- mannen zijn, wat de duur van de stoelgang betreft, persoonlijk stabieler dan vrouwen;

- vooral de vrouwen van jonger dan 40 jaar blijken de toiletgang uit te stellen.

Zijn er behalve bovenbeschreven leeftijd-en seksegebonden defecatiepatronen nog verdere differentiaties mogelijk? Zo ja, dragen die dan bij aan een verder inzicht in het 'normale' defecatiepatroon?

$B \mathrm{ij}$ de analyse van kenmerkende variabelen van het wc-gedrag en belevingsaspecten daaromtrent dienden zich onderlinge verbanden aan die relevant leken voor bepaalcle typeringen van toiletgedrag. Op genoemde vragen en desbetreffende analysebevindingen zal nader worden ingegaan in hoofdstuk 4 . 


\section{Determinanten van beleving van de stoelgang in een gezonde populatie}

\subsection{Beleving van de stoelgang: mogelijke determinanten}

De uitscheiding is een menselijke functie die met gevoelens samenhangt. Defecatie zelf kan bron zijn van lustgevoelens - zoals het woord "ontlasting" aangeeft - en onlustgevoelens; als zodanig kunnen die aangename of minder angename gewaarwordingen van invloed zijn op iemands gedrag. Anderzijds kan de stoelgang, als vorm van menselijk gedrag, worden beïnvloed door omstandigheden of factoren van uiteenlopende aard.

Zo blijken het ontlastingsproces en de -produkten voor sommigen wel, voor anderen niet of minder onderwerp van gedetailleerde aandacht. Sommigen schamen zich meer dan anderen voor de geuren en geluiden waarmee de defecatie gepaard gaat. Sommigen blijken gevoelig, anderen minder of niet, voor omstandigheden van hygiene of ook van huiselijke intimiteit, waaronder: de stoelgang platsvindt. Sommigen vinden, meer in het algemeen gesproken, de stoelgang 'een rustpunt gedurende de dag', anderen veeleer' 'een noodzakelijk kwaad'. Als globale doelstelling van het deelonderzoek walarover in dit hoofdstuk verslag wordt gedaan, geldt dan ook: meer inzicht verkrijgen in belevingsaspecten gerelateerd aan de stoelgang.

Gevoelens waarmee de stoelgang gepaard kan gaan worden in de literatuur veelal gerelateerd aan stoomissen, hetzij als oorzaak (bijvoorbeeld van buikklachten, Van Wijk 1988, c.q. encopresis, Wolters 1974, Lighthart 1988), hetzij als gevolg van lichamelijk dysfunctioneren (bijwoorbeeld schaamte, angst, schuldgevoelens ten gevolge van anale incontinentie: Rubin 1974, Clay 1980, Muir Gray 1980, Shepherd 1980 , Munnichs 1984). Belevingsfactoren en defecatie worden, in relatie tor elkaar, bestudeerd in de ontwikkelingspsychologie (Freud 1905, Groddeck 1926) en in de psychosomatiek (Alexander, 1970). Omtrent beleving, of aspecten van beleving, van de stoelgang bij gezonde mensen wordt niet of zelden gerapporteerd. Het onderzoek naar determinanten van beleving van de stoelgang in een gezonde populatie, walarover hier verslag wordt gedaan, heeft, naast een oriëntatie op determimanten genoemd in de somatische literatuur, dan ook voomamelijk een explorerend karakter.

Tot de factoren die de beleving van de stoelgang beinvloeden behoren allereerst de kenmerken wan de eigen gezondheidstoestand. Aanmemelijk lijkt dat de beleving van de stoelgang mede word beinvloed door factoren zoals de mate van ongemak waamee de ontlasting gepaard gaat, of het gebruik van laxantia.

Bepalend voor de beleving van de defecatie kunnen eveneens gedragingen of 
handelwijzen zijn ten atanzien van stoelganggedrag. Mensen blijken, in hun normale, dagelijkse omgeving, zich bij de stoelgang meer of minder 'op het gemak' te voelen, naarmate men de gewenste materièle afzondering kan realiseren, of naarmate de ontlasting niet wordt verstoord door ongeduldige huisgenoten, door telefoon of voordeurbel. Ook de mate warin men de stoelgang uitstelt, kan worden gezien in relatie tot de genoemde waardering, of ook de tijd die men aan de defecatie besteedt, of moet besteden, of de mate watarin men de eigen ontlasting vindt stinken.

Er kan dus een relatie worden verondersteld tussen de beleving van de stoelgang en gedragswariabelen. Dergelijke variabelen konden, althans ten dele, met behulp van de dagboeken (cf. hoofdstuk 3, hierboven) worden geregistreerd.

Van de stoelgang is bekend dat dit een verrichting is die omkleed kán zijn met hetzij individueel hetzij cultureel bepaalde 'rituelen'. Mensen blijken thuis, in hun normale omgeving, soms gehecht aan de wc-gewoonten of -rituelen. Beperking of verhindering in de uitvoering daarvan, bijvoorbeeld bij uithuizigheid inclusief ziekenhuisopname, kan de normale stoelgang belemmeren. Om deze reden kan worden verondersteld dat de beleving van de stoelgang óók gerelateerd is aan variabelen betreffende soilet-culthur.

Het "normale defecatiepatroon", beschreven in hoofdstuk 3, bleek gedifferentieerd te kunnen worden naar leeftijd en geslacht. Leeftijd en geslacht lijken derhalve (sociaaldemografische) determinanten die eveneens van belang zouden kunnen zijn voor de beleving van de stoelgang.

De beleving van de stoelgang kan dus in samenhang worden gezien met vier groepen factoren, schematisch weergegeven in Figuur 4.1.

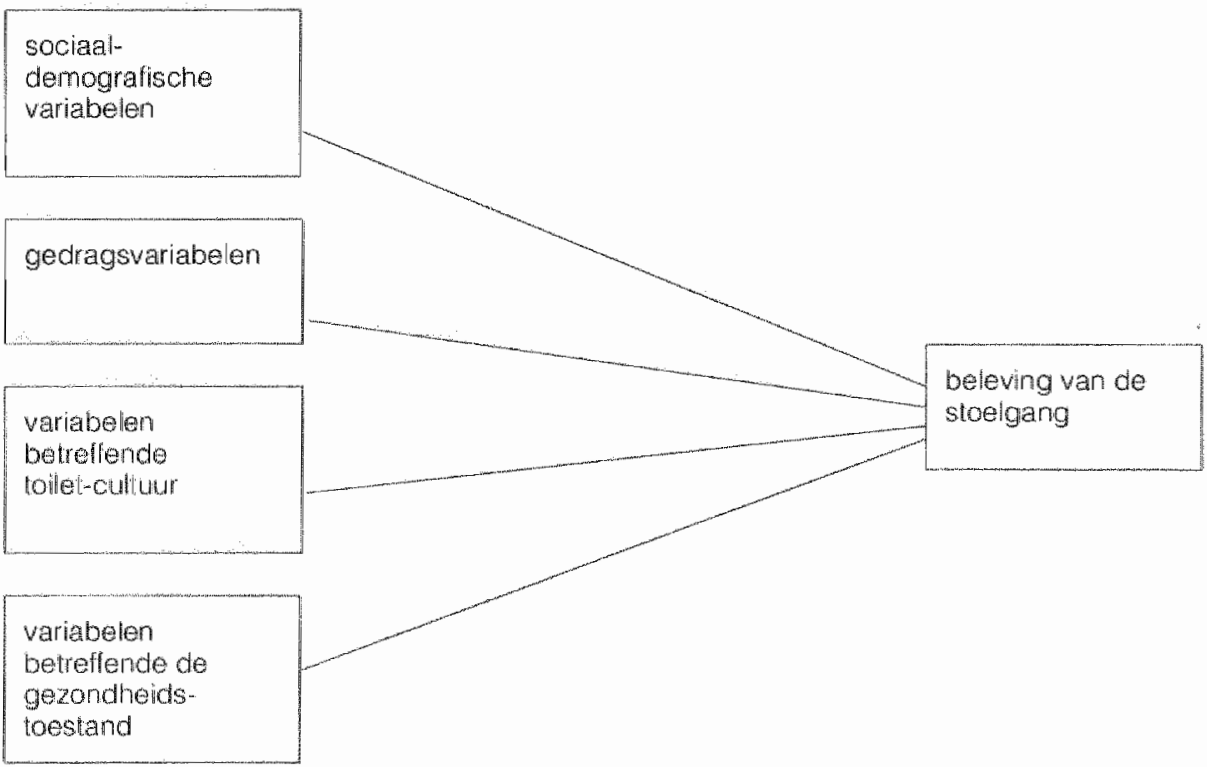

Figuur 4.1 Mogelijke determinanten van stoelgangbeleving 
Het deelonderzoek beoogde de samenhang van deze factoren nader in katart te brengen. De onderzoekswaag luidde:

Hoe is de beleving van de stoelgang epwelke zijn de determinanten wan beleving van de stoelgang in een gezonde populatie?

\subsection{Opzet van het onderzoek}

Om antwoord op bovengeformuleerde vragen te verkrijgen, werd aan een gezonde populatie schriftelijk een aantal vragen over de feitelijkheid en de perceptie van de stoelgang voorgelegd. De onderzoeksgroep en de wijze van dataverzameling, met vooren nadelen, zijn die zoals beschreven in $\$ 3.5$.

Ter bepaling van kenmerken van het defecatiepatroon als eventuele detemninerende factoren van de beleving van de stoelgang, werd de respondenten gevraagd gedurende veertien dagen een dagboek bij te houden met betrekking tot de uitscheiding, intake van voedsel, inname van medicijnen en gebruik van laxerende produkten, consumptie van alcohol en de mate van lichaamsbeweging. Tevens werd de participanten een enquêteformulier alsook de lijst Vragen Over Ervaren Gezondheid, de VOEG-lijst, voorgelegd.

In de schriftelijke enquête werd naast de sociaal-demografische gegevens informatie gevmaagd omtrent de toilet-culturr van de respondenten, en bepaalde gegevens betreffende de gezondheidstoestand. Ontrent de laatstgenoemde variabele werd eveneens informatie ontleend aan de VOEG-lijsten. Informatie ontrent de gedragsvariabelen werd ontleend aan de dagboeken.

\subsection{Vier belevingsvarianten ten aanzien van ontlasting}

Met betrekking tot de 'beleving van de stoelgang' werden aan de onderzoekspopulatie 22 op face-validity geselecteerde vragen voorgelegd betreffende stoelganggedrag en bijkomende gevoelens (zie Tabel 4.1).

Uit deze Tabel blikt dat omtrent aspecten van stoelgang(gedrag) de percentages instemmende antwoorden uiteenlopen: hef mijden van winden in gezelschap $(88 \%)$, of de hinderlijkheid van andermans ontlastingsgeuren $(87 \%$ ), tegenover lectuur op toilet aanwezig (19\%), en het feit of men zich gemakkelijk laat verstoren tijdens de stoelgung $(23 \%)$

Op de belevings- en gedragsvariabelen werd vervolgens een factoranalyse uitgevoerd. Van de variantie in de variabelen wordt 42 procent verklaard door de eerste vier factoren (Eigenvalue resp. 3.66, 2.87, 1.90, en 1.62). Na rotatie volgens het varimaxcriterium op de eerste vier, drie en wwee factoren, bleek de vierdimensionale oplossing het best te interpreteren. In Tabel 4. I staan de factorladingen weergegeven. Alleen factorladingen met een waarde van .40 worden bij de interpretatie betrokken.

Vier factoren konden worden geidentificeerd. De items van de eerste factor bevatten informatie over schiamte die men ervaart bij eigen en andermans winderigheid. Men 
Tabel 4. Frequentieverdeling en factorladingen op de eerste vier factoren na varimaxrotatie

$\begin{array}{llll}\text { Variabelen } & \begin{array}{l}\text { \% instemmende Factor } 1 \text { Factor } 2 \\ \text { antwoorden }\end{array} & \text { Factor } 3 \text { Factor } 4\end{array}$

Factor 1: 'Schaamte

voor winden'

- Vindt winden wan anderen hinderlibik

56

.73

.05

14

.05

s. Schaamt zioh voor winden in

gezelschap

62

.60

$-0.06$

$-0.04$

10

- Laal geen winden in gezelschap

- Laat winden niet hoorbaar

.60

$-0.13$

.16

77

.60

$-0.40$

.24

\section{Factor 2:}

'Geur-gevoeligheid'

- Na de silcelgang iemand waarschu wen te wachten

- Uithuizig verandert ontlastingspatroon

- Stelt de stoelgang uit als wo stinkt

- Tijdens stoelgang gemakkelijk le verstoren

ontlasting stinken

- Korter wo-verbllijf door lucht van anderen

Vindt iucht van anderen hinclerlijk

Factor 3: 'Hyglëne-gevoelighieid'

- Hygienische omstandigheden bepalend voor wc-gebrulk

- Vindl eiders drukken moeilijk

- Vindt elders plassen moeilitk

- Ulistel van de sloelgang bif vuil toilet

6

77

64

22

64

41

56

74
.20

$-0.14$

0.00

.24

.10

$-0.15$

.03

- Toiletbezoek is niet een 'noodzakelijk kwaad'

- Neent "de tijd" voor de stoelgang
.79

$-0.05$

$-0.05$ 


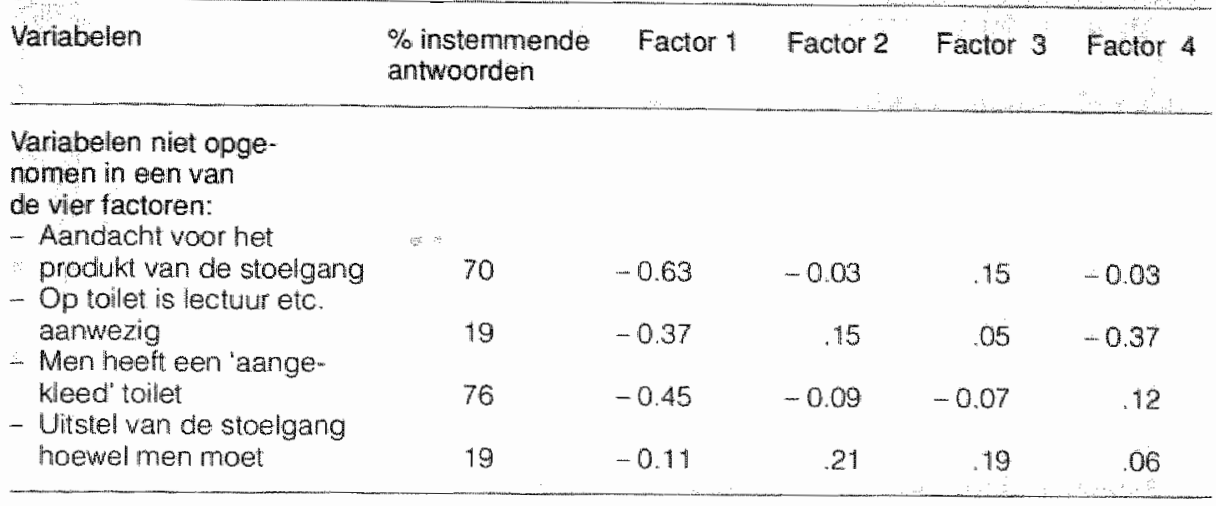

vindt winden hinderlijk, men schaamt zich ervoor, men laat winden niet in gezelschap, men laat winden niet hoorbaar. Factor 1 werd dus geïnterpreteerd als "schaamte voor winden'. Op deze nieuwe variabele, met interne consistentie Cronb. $\alpha=.71$, kon theoretisch minimaal 4 en maximaal 8 worden gescoord: dit bleek in de realiteit het geval. Gemiddeide en standaarddeviatie bedroegen 6.4 , respectievelijk 1.5 .

Factor 2 bevat eveneens informatie over schaamte althans (over)gevoeligheid, maar nu ten aanzien van ontlastingsgeuren. Men vindt andermans geuren hinderlijk; men stelt er wc-bezoek voor uit. Voor de eigen lucht schaamt men zich. Wachtende toiletgebruikers, die aandringen op spoed, verstoren de stoelgang. Na de defecatie waarschuwt men de wachtende het toilet even niet te gebruiken. Uithuizig verkiest men liever niet naar toilet te gaan. Deze factor wordt geïnterpreteerd als 'geur-gevoeligheid'; interne consistentie is: Cronb. $\alpha=66$. Op deze nieuwe variabele werd potentieel en feitelijk gescoord van minimaal 7 tot maximaal 14. Gemiddelde en standaarddeviatie bedroegen respectievelijk 10.3 en 1.8 .

Factor 3 bevat informatie over de gevoeligheid voor hygiënische omstandigheden op het toilet. Deze blijken bepalend voor het al dan niet gebruik van het toilet. Bij cen vuil toilet stelt men de stoelgang liever uit. Verkeert men buitenshuis, dan gebruikt men de vreemde wc-bril liever niet. Elders naar toilet gaan, voor urineren of defeceren, wordt als moeilijk ervaren. Deze factor, met interne consistentie: Cronb. $\alpha=.68$, word geinterpreteerd als 'hygiëne-gevoeligheid'. Ook op deze nieuwe variabele werd datgene gescoord wat theoretisch mogelijk was, namelijk 5 als minimum en 10 als maximum. Het gemiddelde bedroeg 7.7, de standaarddeviatie 1.5.

De items in factor 4 tenslotte geven uitdrukking aan een bepaalde houding van de respondent ten opzichte van de stoelgang. Deze bleek men als problematisch, cen 'noodzakelijk kwaad' te ervaren, dan wel als een 'rustpunt gedurende de dag', watrvoor men de tijd neemt. Deze factor, met interne consistentie: Cronb. $\alpha=.60$, wordt geinterpreteerd als 'toilet-attitude'. De scores bleken tussen 3 en 6 gelegen, hetgeen ook de theoretische mogelijkheid was. Gemiddelde en standaarddeviatie bedroegen respectievelijk 4.3 en 1.1 .

Enkele items bleken op geen van de vier factoren te laden, ofwel werden om 
inhoudelijke redenen niet bij de nieuw gevormde variabelen betrokken. De variabelen die als cultureel bepaalde determinanten van stoelgangbeleving waren aangemerkt, namelijk betreffende de aankleding van de toiletruimte, alsook "we-lezen", zullen afzonderlijk in de verdere analyse worden betrokken.

Van de beleving wan de stoelgang blijken dus vier aspecten of dimensies benoemd te kunnen worden. Deze belevingsaspecten bliken alle een overwegend problematische inslag te hebben. Omdat determinanten van (problematische) stoelgangbeleving bij sommigen kunnen culmineren, werd uit de vier benoemde 'determinanten van beleving van đle stoelgang" één variabele samengesteld, "wc-problemen", als indicatie voor meer of minder moeilijkheden omtrent de stoelgang. De vorming van de nieuwe variabele kwam tot stand door middel van sommering van de standaardscores van de vier variabelen. Interne consistentie bedraagt: Cronb. $\alpha=.41$.

Een overzicht van Pearsons correlatiecoëfficiënten toont relaties aan tussen deze belevingsvarianten (label 4.2 ).

Tabel 4.2 Intercorrelaties tussen de belevingsvarianten

\begin{tabular}{|c|c|c|c|c|}
\hline $\begin{array}{l}\text { schaamte } \\
\text { voor winden }\end{array}$ & $\begin{array}{l}\text { geur- } \\
\text { geveligheid }\end{array}$ & $\begin{array}{l}\text { thygiene- } \\
\text { gevoeligheid }\end{array}$ & $\begin{array}{l}\text { (problemat.) } \\
\text { toil-attitude }\end{array}$ & $\begin{array}{l}\text { wo-pro- } \\
\text { blemen }\end{array}$ \\
\hline $\begin{array}{l}\text { schaamte } \\
\text { woor winden }\end{array}$ & $r=.02$ & $r=25^{\text {* }}$ & $r=.09$ & $r=.55^{* * *}$ \\
\hline $\begin{array}{l}\text { geur- } \\
\text { gevoeligheid }\end{array}$ & & $r=.31 * *$ & $r=.12$ & $r=.60^{4 x x}$ \\
\hline $\begin{array}{l}\text { hygiene- } \\
\text { gevoeligheid }\end{array}$ & & & $r=24^{*}$ & $r=.73^{* * *}$ \\
\hline $\begin{array}{l}\text { (problematische) } \\
\text { toilet-attitude }\end{array}$ & & & & $r=59^{n \times \cdots}$ \\
\hline
\end{tabular}

$*=p \leq 0.05$

*h $=p \leq 0.01$

$* * * p \leq 0.001$

Uit Tabel 4.2 blijkt dat 'wc-problemen' significant samenhangen met de vier overige variabelen - hetgeen voor de hand ligt, aangezien 'wc-problemen' uit deze variabelen is samengesteld. 'Hygiënegevoeligheid' blijkt te correleren met 'schaamte voor winden', 'geurgevoeligheid' en met de 'problematische toillet-attitude'. Tussen de drie laatstgenoemde variabelen blijkt geen samenhang.

\subsection{De onafhankelijke variabelen}

De variabelen die als determinerend van de stoelgangbeleving waren aangemerkt zijn, gegroepeerd, in Tabel 4.3 weergegeven. 
Tabel 4.3 Onafhankelijke variabelen, met frequentieverdeling, bij 'Belewing van de stoelgang'

\section{Variabelen}

Sociaal-demografische variabelen:

- leettijd:

- gestacht:

$39 \%>40$ jog

$39 \%$ mannen

Gedragsvariabelen:

- frequentie van de stoelgang.

$9 \%<4 x$ per weeth

$67 \% 5$-9x per week

$24 \%>10 x$ per week

- arntal minuten per stoelgang:

$34 \%<5$ min per stoelg.

$44 \% 5$ min.

$12 \%>5 \mathrm{~min}$.

- vind eigen ontlasting vaak stinken:

$32 \%$ (valk)

$44 \%$ (soms)

$23 \%$ (noot)

- is zell winderig

$48 \%$ (alijd/vaak)

- stelt defecatie uit

$52 \%$ (zelden/nooit)

$26 \%$ (vala)

$34 \%$ (soms)

$40 \%$ (nooil)

Toilet-cultuur

- op toltel lectuur etc. aarwezig

$19 \%(j a$, meestal)

$81 \%$ (niel)

$76 \%$ (je, meestal)

- heeft een 'aangekleed" toile!

$24 \%$ (niet)

Gezondheidstoestand

- maag-/buikklachten volgens VOEG

$67 \%$ (nee)

$23 \%$ (beetie)

$10 \%$ (veel)

- klachten over postuur volgens VOEG

$68 \%$ (nee)

$28 \%$ (te dik)

$4 \%$ (te mager)

- ervaart lichamelijk ongemak

$21 \%$ (vaak)

$26 \%$ (soms)

$53 \%$ (nooit)

$27 \%$ (valis)

gebruikt laxerende middelen

$73 \%$ (zeldenhooit)

De sociaal-demografische variabelen leeftijd en geslacht werden, als kenmerken wan de populatie, toegelicht in hoofdstuk 3, evenals kenmerken van het "normale defecatiepatroon", zoals de frequentie, de duur, de hoeveelheid ontlasting per stoelgang, het uitstelgedrag van de respondenten, enzovoort.

Onder de cluster toilet-cultuur worden de twee cultureel bepaalde kenmerken van wc-gedrag vermeld, namelijk het bezit van een behalve met de gebruikelijke kalender en spiegel ook met posters, planten, curiosa etc. "angeklede" toiletruimte; en vervolgens de meer specifieke aanwezigheid van lectuur. In onze populatie blijkt een betrekkelijk gering aantal respondenten (19\%) op toilet te lezen; de meerderheid daarentegen $(76 \%)$ beschikt over een "aangekleed" toilet. 
Onder gezondheidstoestand zijin variabelen gegroepeerd betreffende lichamelijke klachten die als min of meer aan de stoelgang gerelateerd beschouwd kunnen worden. Klachten betreffende aambeien, anale kloofjes, pijn bij het persen, komen bij bijna de helft van de respondenten valak of soms voor $(47 \%)$. Vervolgens maag-en buikklachten, en zich te dik voelen. Tenslotte een indicatie omtrent het gebruik van laxerende middelen: $27 \%$.

Ter bepaling van determinanten van de vier belevingsvarianten werd een stapsgewijze multiple regressie-anallyse uitgevoerd met elk van de varianten achtereenvolgens als afhankelijke variabele. Ditzelfde werd uitgevoerd met "wc-problemen" als afhankelijke variabele (Tabel 4.4).

Tabel 4.4 geeft de significante correlaties weer tussen de onafhankelijke variabelen en elk van de vier belevingsvarianten, resp. van de globale variabele "wc-problemer". We-problemen blijken beduidend meer voor te komen bij vrouwen, alsook bij degenen die niet beschikken over een 'aangeklede' wc. Met betrekking tot de vier afzonderlijke belevingsvarianten, blijkt, gezien de hoogte van de B-coëfficiënten, dat

Tabel 4.4 Bèta-coëfficiënten in stapsgewijze multiple regressie-analyse, resp. significante nulde-orde correlatiecoëfficiënten 'Determinanten stoelgang-beleving', bij $p \leq 0.05$

Onafhankelijke variabelen:

Sociaal-demogralische variabelen:

leeltijd

geslacht

Gedragsvariabelen:

frequentie van de stoelgang

aantal minuten per stoelgang

windt eigen ontlasting stinken

is zelf winderig

stelt defecatie uit

Toilet-cultuur:

leest op toilest

heeft "aangeklede" wo

\section{Gezondheidstoestand:}

matag-buikklachten volgens VOEG

klachten over postuur (te dik)

lichamelikk ongemak bij stoelgang

gebruikt laxerende middelen 
- problematische toilet-attitude negatief correleert met de duur van de afzonderlijke stoelgang;

- schaamte voor geuren groter is bij degenen die laxerende middelen gebruiken;

- schaamte voor winden vooral bij ouderen voorkomt;

- vooral vrouwen gevoelig zijn voor hygiënische wc-onstandigheden.

\subsection{Onderlinge structuur tussen onafharkelijke variabelen}

De onafhankelijke variabelen die in enigerlei mate correleren met de gedrags- en belevingsvarianten en met "wc-problemen', kunnen echter onderling samenhangen, zelfs de relatie tot de afhankelijke variabelen onderling versterken. Daarom wordt, vervolgens, met behulp van de correlatiematrix, gezocht naar structuur tussen de onafhankelijke variabelen onderling, alsook tussen de onafhankelijke variabelen en andere relevante variabelen. 
Tabel 4.5 Pearsons correlatie-coëfficięnten tussen predictor - en correlerende variabelen (alle r's significant bij $p<0.05$ )

Predictor Variabele

minuten per stoelgang

leeftijd

Irequentie van de stoelgang

vindt eigen ontlasting vaak stinken

$-0.22$

$-0.21$

$-0.17$

vind eigen ontlasting vaak

stinken

men is zelf winderig

frequentie van de stoelgang

men woelt zich te dik

$-0.20$

4.4

men is zelf winderig

'aangekleed' toillet

leettijd

leest op toilet

leeftiigd

lichamelijk angemak bij stoelgang

$-0.33$

aantal minuten per stoelgang

frequertie van de stoelgang

maagklachten volgens de VOEG

men woelt zich te dik 20 lichamelijk angemak geslacht: vrouw

gebruik laxerende middelen

geslacht: vrouw

Tabel 4.5 laat zien dat, en in welke mate, onafhankelijke variabelen onderling correleren. De frequentie van de stoelgang, bijvoorbeeld, correleert hoog met het vaak vinden stinken van de eigen ontlasting. Soms liggen de verbanden voor de hand: hoe vaker men naar de wc gaat, des te korter duurt het verblijf per stoelgang. Opmerkelijk. tenslotte, is dat verschillende variabelen met verschillende andere correleren: er ontstaat een netwerk van interdependenties dat, als een uiteindelijk verklarend schema van 'determinanten van beleving van de stoelgang', met ondersteunende structuur van variabelen, wordt voorgesteld in Model 4.2.

De 'determinanten van beleving van de stoelgang in een gezonde populatie' kunnen aan de hand van Model 4.2 als volgt worden benoemd.

1. Schaamte voor winden, toenemend naarmate men ouder is.

2. Hygiëne-gevoeligheid. Deze komt blijkbaar meer voor bij vrouwen. Naarmate men gevoeliger is voor hygiënische omstandighteden op toilet, duurt de stoelgang korter. 


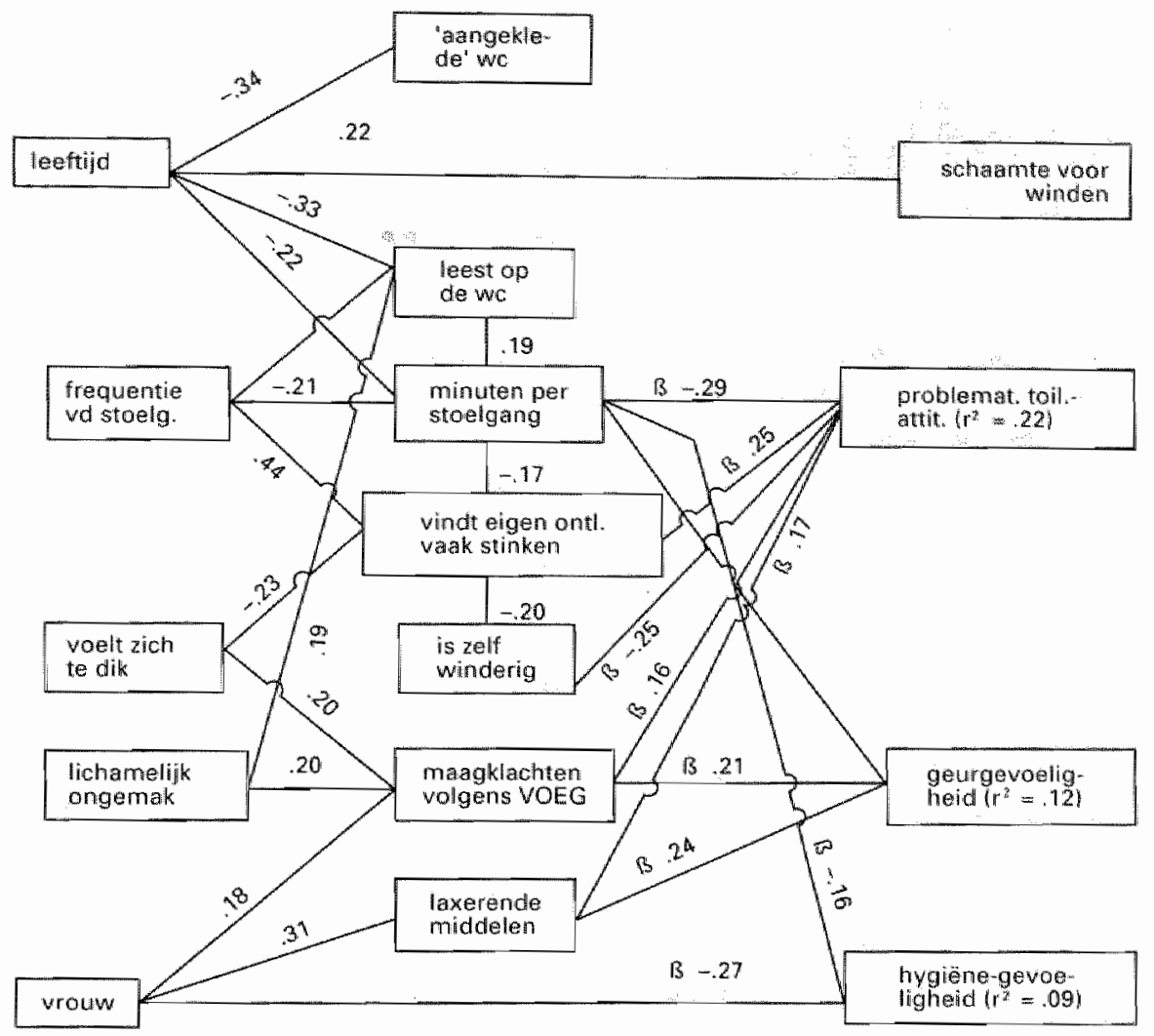

Model 4.2 Determinanten van beleving van de stoelgang, in een gezonde populatie

3. Schaamte of gevoeligheid voor ontlastingsgeuren, meer optredend indien:

a. men per stoelgang korter op het toilet verblijf, wat het geval kan zijn:

-marmate men zich frequenter ontlast,

- naarmate men ouder is,

- narmate men minder leest op de wc.

b. men blijk geeft van maag-/buikklachten, wat het geval kan zijn:

- naarmate men zich te dik voelt.

- naarmate men meer last heeft van lichamelijk ongemak bij de stoelgang,

- bij vrouwen.

c. men meer laxerende produkten gebruikt, wat vooral bij vrouwen het geval blijkt te zijn.

4. Een 'problematische toilet-attitude', meer optredend indien:

a. men per stoelgang korter op het toilet verblijft, wat het geval kan zijn.

- naarmate men ouder is, 
- namate men zich frequenter ontlast,

- natrmate men minder leest op de wc.

b. men minder winderig blijkt te zijn.

c. men meer vindt dat de eigen ontasting stinkt, wat het geval kan zijn:

- naamate men zich minder frequent ontlast.

- naarmate men meer winderig blijkit te zijn,

- naamate men zich te mager vindt.

d. men blik geeft van maag-/buikklachten, wat het geval kan zijn:

- naamate men zich te dik voelt,

- naamate men meer last heeft wan lichamelijk ongemak bij de stoelgang.

- bij vrouwen.

e. men meer laxerende middelen gebruikt, hetgeen bij wrowwen vaker het geval is.

\section{Kortom:}

1. Ouderen schamen zich meer voor winden.

2. Vrouwen zijn gevoeliger voor hygiënüsche omstandigheden.

3. Degenen met maag- en buikklachten en degenen die laxerende produkten gebruiken, schamen zich meer voor ontlastingsgeuren; degenen die zich voor geuren schamen, verblijven korter per stoelgang op de wc.

4. Van een problematische toilet-attitude geven blijk: degenen met maag-en buikklachten, degenen die laxerende produkten gebruiken, die vaak vinden dat de eigen ontlasting stinkt, die per stoelgang korte tijd op de wc blijven, en die zelf winderig zijn.

\subsection{Problematische beleving van de stoelgang: differentiatie naar geslacht en naar leeftijd}

Daar verwacht kan worden dat leeftijd en geslacht interacteren met de afhankelijke variabele, is besloten met de samengevoegde variabele 'wc-problemen' een stapsge-

Tabal 4.6 Stapsgewijze multiple regressie-analyse op 'wc-problemen', afzonderlijk per leeftildscategorie van jonger en oudler dan 40 jaar

$r^{2}=19$

adj $r^{2}=15$

mern is zelf winderig

maag-jbukklachen (volgens de VOEG) 
wijze multiple regressie-analyse nit te voeren voor de afzonderlijke leeftijdscategoriejn van jonger en van ouder dan 40 jaar (Tabel 4.6 ).

Uit deze analyse blijkt dat we-problematiek bij jongeren vaker vookomt natmate men meer winderig is, of ook naarmate men meer maag-en buikklachten aangeeft op de VOEG. Bij de ouderen blijken wc-problemen gerelateerd aan het gebruik van laxerende middelen, alsook aan, achtereenvolgens, het geslacht en lichamelijk ongemak bij de stoelgang.

Bij variantie-analyse bleek geen extra interactie-efiect van de variabele "leeftijd".

Eveneens werd op "wc-problemen" een stapsgewijze multiple regressie-analyse uitgevoerd, afzonderlijk per geslacht (Tabel 4.7).

Wat v rouwen betreft doen wc-problemen zich wooral voor bij degenen wier toiletruimte niet is 'aangekleed', en naarmate zij meer laxerende middelen gebruiken en blijk geven van maag-en buikklachten. $\mathrm{Bij}$ mannen doen wc-problemen zich meer voor na:urmate zij minder laxerende middelen gebruiken en lichamelijk ongemak ervaren bij de stoelgang.

Met behulp van variantie-analyse werd extra interactie vastgesteld tussen de variabele 'geslacht' en de variabelen benoemd in de multiple regressie-analyse (uitgezonderd de variabele 'maag-/buikklachten volgens de VOEG', waarbij een scheve verdeling van het statistisch materiaal de analyse bemoeilijkte).

Specifieke samenhang bleek aanwezig tussen 'geslacht' en beide cultureel bepalde variabelen. Bij vrouwen die beschikken over een 'aangeklede' toiletruimte worden minder wc-problemen geconstateerd (Fig. 4.2). Ook komen wc-problemen minder voor bij wrouwen die lezen (etc.) op toilet, dan bij degenen die niet wc-lezen. Bij manmen is dit eveneens het geval, zij het significant minder (Fig. 4.1).

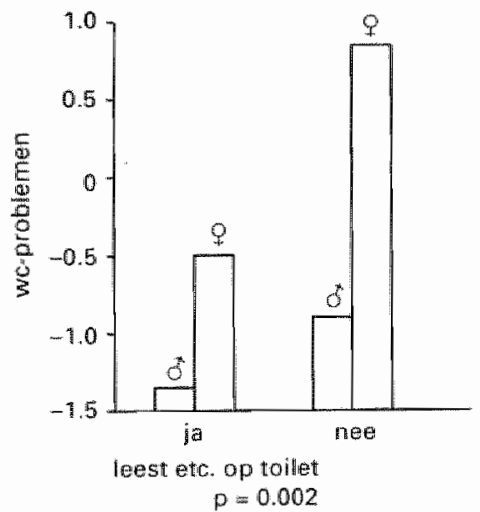

Fig. 4.1 Interactie geslacht met 'lezen op wc', in relatie lot 'wc-problemen'

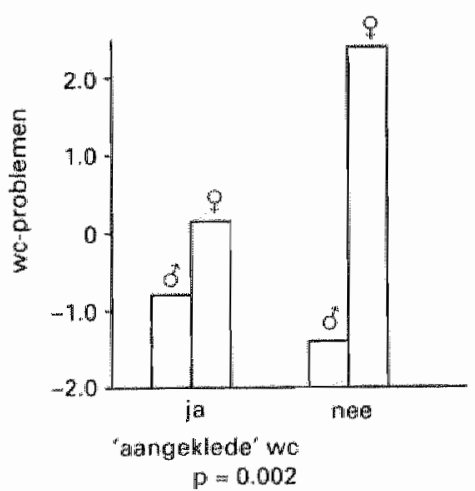

Fig. 4.2 Interactie geslacht met "aangekle. de wc', in relatie tot ' $w C$-problemen' 
$r^{2}=33$

adi. $r^{2}=29$

'aangeklede' tollet-rumte

gebruik van laxerende middelen

maniven:

$r^{2}=27$

adi $r^{2}=23$

Eveneens werd specifieke samenhang geconstateerd tussen 'geslacht' en twee gezondheidsvariabelen. Bij vrouwen die laxerende middelen gebruiken, komen meer wc-problemen voor dan bij mannen in deze situatie; bij mannen en vrouwen die geen laxerende midclelen gebruiken is het verschil in de hoeveelheid wc-problemen aanmerkelijk geringer (Fig. 4.4). Evenzo komen er meer wc-problemen voor bij vrouwen dan bij mannen die lichamelijk ongemak bij de stoelgang ervaren; bij vrouwen en mannen met geen of een beetje ongemak is het verschil in de mate van wc-problematiek aanmerkelijk geringer (Fig. 4.3).
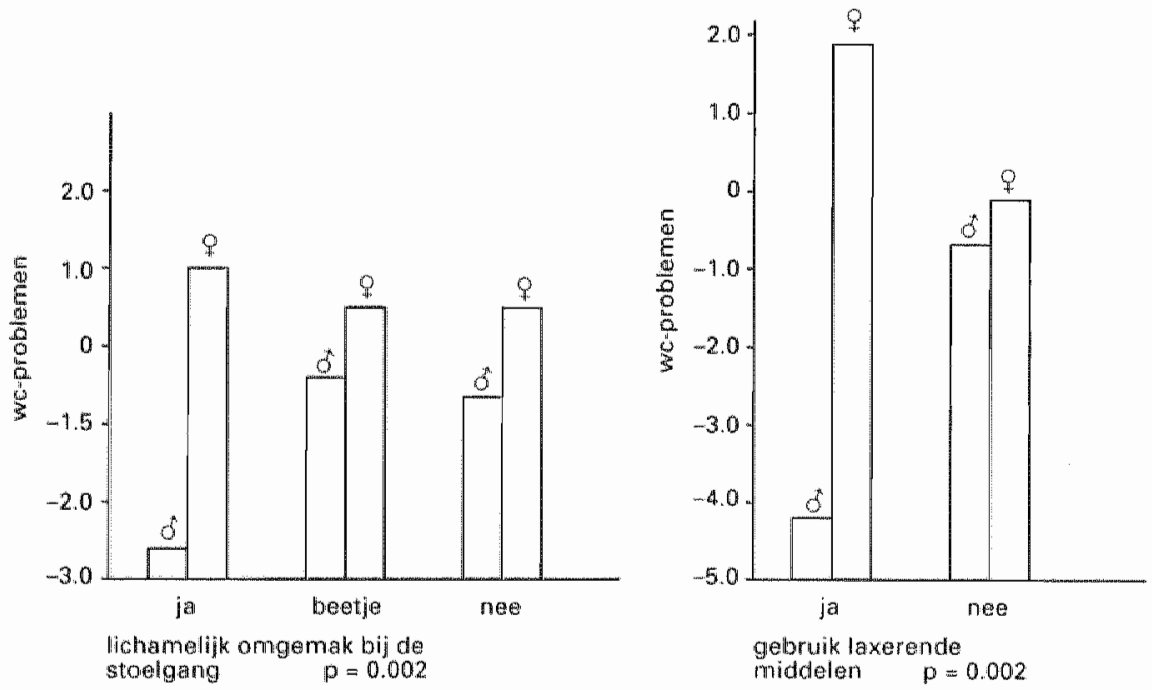

Fig. 4.3 Interactie geslacht met 'lichamelijk ongemak', in relatie tot 'wcproblemen'
Fig. 4.4 Interactie geslacht met gebruik laxerende middelen' in relatie tot "wc-problemen 
Kortom: bij respondenten met we-problemen betreft het vooral de vrouwen ingeval er werband wordt gevonden met het gebruik van laxerende middelen en met lichamelijk ongemak bij de stoelgang. Eweneens betreft het de vrouwen wanneer we-problemen in nelatie worden gezien mel afwezigheid van "wc-cultuur".

\subsection{Discussie en conclusies}

4.7.1 Ten aanzien wan het onderzoek waarover hier verslag wordt gedatan gelden tweeèrlei beperkingen: de geringe theoretische inkadering en de trelatief kleine onderzoekspopulatie.

De beperk theid van de theoretische inkadering, bij afwezigheid van relevante litera tuur, resulteerde in het explorerende karakter van dit onderzoek. Enerzijds heef dit her woordeel dat het de onderzoeker in staat stelt onvermoede relaties tussen wariabelen te exploreren; anderzijds het nadeel van een zekere willekeur in de procesgang van het onderzoek. Zo kwam het onderscheid tussen vier belevingsvarianten van de stoelgang weliswaar tot stand aan de hand van factoranalyse, mar deze werd uitgevoerd op een 22-tal aan de respondenten voorgelegde variabelen waarvan de validiteit niet voordien was vastgesteld. Ook de onafhankelijke variabelen, en de clustering ervan tot vier groepen, berustte evenmin op een geëxpliciteerd theoretisch fundament. Vervolgonderzoek naar "Determinanten van beleving van de stoelgang in een gezonde populatie" zou gebaat zijn bij een duidelijker omschreven theoretisch kader - mede te baseren op de hier gerapporteerde, explorerend verkregen onderzoeksresultaten.

De beperkingen inherent aan de relatief kleine onderzoeksgroep hebben hun weerslag op de statistische bewerking van de data. Subgroepen - de populatie werd soms ingedeeld naar geslacht én naar leeftijdscategorieèn - bleken dan te gering van omvang voor het doen van uitspraken hen betreffende met voldoende betrou waarheid. Bepralde statistische bewerkingen leken dan nauwelijks verantwoord, bijvoorbeeld variantieanalyse ter vaststelling van extra interactie-effect, waarbij de betrokken subgroepen soms een (te?) gering aantal respondenten bevatten. In deze twijfelachtige gevallen is niet altijd van verdere analyse afgezien; deze werd tentatief voortgezet, aldus de grenzen van het stat istisch toelatbare warschijnlijk soms overschrijdend. Hat 'creèren van optimale kansen voor het toeval', een terrein verkennen warop nog weinig onderzoek was gepubliceerd, was daarbij de bewoegreden.

4.7.2 Beleving van de stoelgang uit zich, blijkens thet hier gerapporteerde deelonderzoek, op vier van elkaar onderscheiden wijzen: drie ervan verwijzen naar speciale gevoeligheden van mensen (gevoeligheid voor hygiënische omstandigheden, voor ontlastingsgeuren, voor winden), de vierde geeft een globale houding ten aanzien van de stoelgang weer, 'toilet-attitude'. Van elk van deze vier belevingsfactoren werden, via multiple regressie-analyse, de determinanten in volgorde van belangrijkheid benoemd. Daarbij blijken de vier belevingsfactoren in eerste instantie elk gerelateerd aan verschillende onafhankelijke variabelen. Reden dus te vermoeden dat achter elk van de vier factoren zich een verschillend leef- of gedragspatroon zou aftekenen.

"Schaante voor winden" blijkt gerelateerd aan de leeftijd: vooral de ouderen blijken 
gevoelig op dit punt. Bij de uitscheiding gehoord worden of mee te luisteren blijkt 'pijnlijk" (in de betekenis van Elias, 1982) voor wie een half leven van driftbeheersing achter zich heeft.

'Geurgevoeligheid' blijkt op de eerste plaats gerelateerd aan het gebruik van laxerende middelen (medicijnen en natuurlijke produkten). Een extra interactie-effect met 'geslacht' - laxerende middelen worden vooral gebruikt door vrouwen - werd niet geconstateerd, zodat 'geurgevoeligheid' kenmerkend kan heten woor alle zogenoemde harcllijvigen.

'Hygiênegevoelig' bleken met name de vrouwen. Omdat onze huidige, westerse. samenleving wil dat vrouwen zittend defeceren én urineren, dus in alle omstandigheden lijfelijk contact hebben met het sanitair, kan worden angenomen dat deze in feite typisch vrouwelijke vorm van stoelgangbeleving zowel anatomisch-fysiologisch alsook cultureel bepaald is.

Van de 'toilet-atritude", de meer globale, minder specifieke belevingsfactor van de stoelgang, bijkkt "het aantal minuten per stoelgang' de belangrijkste indicator. Wanneer men de ontlasting niet ervaart als een rustpunt, maar eerder als een noodzakelijk kwaad, verblijft men kort, zo kort mogelijk op de wc. Overigens is de korte duur van de defecatie eveneens een determinant gebleken van de belevingsfactoren 'geurgevoeligheid' en 'hygiënegevoeligheid'. Hoewel de Pearsons correlatiematrix verbanden laat zien tussen het aantal minuten per stoelgang en tenminste vier andere variabelen, zoals gevisualiseerd in Model 4.2, blijken uit de variantie-analyse geen of nauwelijks interactie-effecten. Het geringe aantal minuten per defecatie is dus een belangrijke determinant van de 'problematische toilet-attitude', hoewel niet aanwijsbaar een exponent van (een) bepaalde gedragscomplex(en).

'WC-problemen', als globale, totaliserende belevingsfactor, blijken vooral gerelateerd aan het geslacht: de problematiek doet zich met name voor bij vrouwen. Met behulp van variantie-analyse werd het extra interactie-effect van 'geslacht' geconstateerd. Bij multiple regressie-analyse, uitgevoerd per sekse afzonderlijk, bleken de gezondheidsvariabelen 'gebruik van laxerende middelen' en 'maag- en buikklachteri' voor vrouwen, en 'laxerende middelen' en 'lichamelijk ongemak bij de stoelgang' voor mannen belangrijke determinanten bij "wc-problemen". Gezondheidsvariabelen als indicatoren voor wc-problemen lijken alleszins aannemelijk.

Echter, de cultureel bepaalde variabelen blijken eveneens een belangrijke rol te spelen bij de beleving van de stoelgang. Lezen (etc.) op de wc en een 'aangeklede" wc bezitten zijn variabelen die over het algemeen gerelateerd blijken aan niet-problematische stoelgang. Onder degenen met wc-problemen hebben vooral de vrouwen geen wc-cultuur. Specialal interactie-effect van 'geslacht' werd hier vastgesteld.

Hebben dus met name de vrouwen de wc-ruimten huiselijk ingericht? Of percipiëren de vrouwen, in tegenstelling tot de mannen, deze ruimte 'aangekleed' alls, behorende tot het interieur, als woon 'verblijf'? Misschien wordt met dit verschil in beleving van de toilet-ruimte iets geillustreerd van de verschillende wijzen waarop man en vrouw hun (gezamenlijke) woonruimte beleven, door Buytendijk ooit verwoord als: 'De man heeft een "vertrek", de vrouw heeft een "verblijf".' 


\section{Privacygevoeligheid van ziekenhuispatiënten bij de stoelgang}

\subsection{Inleiding}

Auteurs die een poging ondernemen het begrip privacy te operationaliseren, grijpen over het algemeen terug op het werk van Westin (1967). Op grond van theoretische analyse onderscheidde deze vier "states" (soorten, situaties, toestanden) van privacy, namelijk:

1. 'solitude' (afzondering): alleen zijn, gevrijwaard van andemans blikken,

2. "intimacy" (intimiteit): met een ander of met een kleine groep afgezonderd zijn van de grote groep,

3. 'anonymity' (anonimiteit): zich ongekend temidden van de menigte bevinden,

4. 'reserve' (terughoudendheid): (een) psychologische drempel(s) opwerpen tegen ongewenste bemoeienis.

Met dit onderscheid als uitgangspunt zijn verschillende pogingen ondernomen het begrip privacy(gevoeligheid) te operationaliseren (Marshall 1974, Altman 1976, Hunter, Grinnell \& Blanchard 1978, Smith \& Swanson 1979, Pederson 1979 en 1982, Walden, Nelson \& Smith 1981, Williamson, Swingle \& Stantield 1982, Kline 1983). Bij de op Westin geïnspireerde meetinstrumenten blijft echter vaak onduidelijk wat in feite wordt gemeten. Afwisselend blijken voorwaarden, noodzakelijk voor het verkrijgen van privacy, dan wel maatregelen ter bescherming van privacy onderwerp van onderzoek. Eveneens kan als bezwarlijk worden aangemerkt dat bij de pogingen tot operationaliseren het begrip privacy werd opgeval in zijn meest globale betekenis, dus als van toepassing op een zo breed mogelijk scala van situaties. Conceptuele analyse (zie hoofdstuk 2) toont echter dat behoefte an en inbreuk op privacy zich zeer verschillend $\mathrm{kan}$ voordoen in uiteenlopende situaties.

Om aan deze bezwaren tegemoet te komen werd, met het oog op de specificiteit van het onderwerp - privacygevoeligheid van ziekenhuispatiènten ten opzichte van de stoelgang -- gekozen voor de constructie van een nieuw meetinstrument. gebaseerd op de hierboven genoemde conceptuele analyse. 


\subsection{Operationalisering 'Privacygevoeligheid'}

Onder privacygevoeligheid wordt hier verstaan de mate waarin men privacy verlangt in bepaalde situaties. Het belang dat men hecht aan privacy kan, blijkens de begripsanalyse, worden afgelezen wan:

1. het belang dat men hecht aan de middelen ter bescherming van de privacy, en

2. het gewicht dat ment toekent aan de (pogingen tot) inbreak op de privacy.

ad 1. Middelen ter bescherming van privacy werden eerder (hoofdstuk 2) onderscheiden in:

1.1 maatregelen van materieel-organisatorische aard, en

1.2 gewoonten en gebruiken waarop men zich beroept, van normatieve aard.

ad 2. Inbreuk op privacy werd onderscheiden in:

2.1 het willekeurig of onwillekeurig met behulp van de zintuigen kennis nemen van informatie zonder instemming van betrokkene ( = 'zintuiglijke inbreuken'), en

2.2 bemoeienis, hinderlijke toenadering, hinderlijke aanwezigheid.

Op grond van het bovenstaande kan privacygevoeligheid worden afgemeten aan de hand van het belang dat men hecht aan maatregelen van materieel-organisatorische aard (1.1), zowel te nemen tegen het onttrekken van informatie aan iemand (2.1) alsook tegen hinderlijke bemoeienis (2.2). Daarmaast moet het belang worden vastgesteld dat men hecht aan gewoonten en gebruiken wan normatieve aard (1.2), eveneens ter voorkoming van het ontrekken van informatie (2.2) alsook van hinderlijke bemoeienis (2.2).

De volgende '2×2-matrix' kan dus worden geconstrueerd:

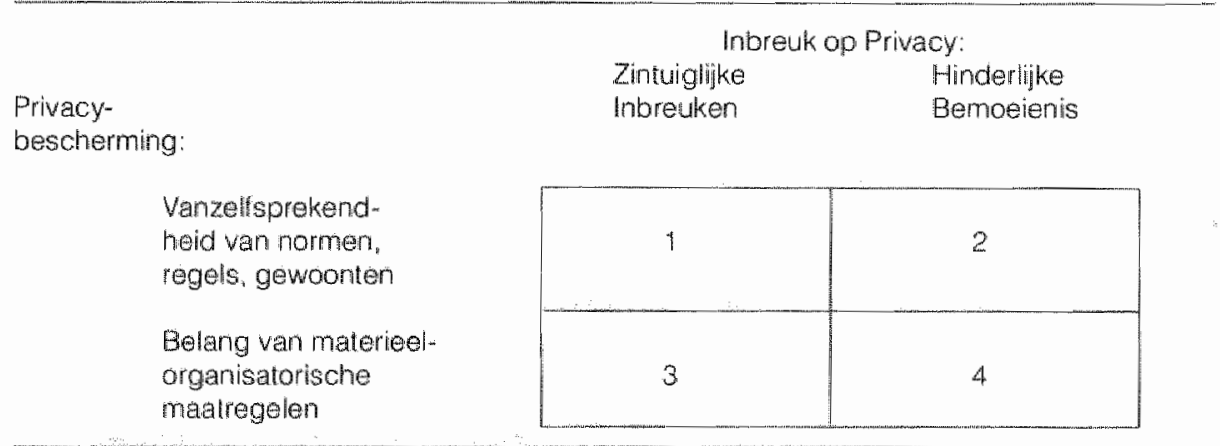

Schema 5.1 Theoretische matrix betreftende privacygevoeligheid

De aldus verkregen vier cellen bevatten de volgende deelonderwerpen van het te construeren meetinstrument:

Cel 1: Gevraagd word naar de mate warin men allerlei regels en gebruiken ter voorkoming van zintuiglijke inbreuken vanzelfsprekend acht. Bijvoorbeeld: als het 
beletlampje van de ziekenkamer brandt, is het gebruikelijk dat men daar niet binnen gaat; veel bezoekers vinden dat vanzelfsprekend, terwijl ziekenhuispersoneel vaak vindt dat men, zelfs zonder kloppen, naar binnen mag.

Cel 2: Gevraagd wordt naar de vanzelfsprekendheid die men toekent aan allerlei regels en gebruiken ter voorkoming wan hinderlijke bemoeienis. Gesprekken over gênante onderwerpen als problemen met de stoelgang voert men gewoonlijk het liefst buiten gehoorafstand van derden.

Cel 3: Gevraagd wordt in welke mate men belang hecht aan maatregelen van materieelorganisatorische aard, ter bescherming tegen zintuiglijke inbreuken op de privacy. Sommige patiënten vinden het belangrijker dan anderen, zich te kunnen afzonderen voor de ontlasting.

Cel 4: Gevraagd wordt naar het belang dat men hecht aan maatregelen van materieelorganisatorische aard tegen hinderlijke bemoeienis. Sommige patiënten stellen het op prijs zélf het moment van de stoelgang te bepalen.

De vier cellen werden vervolgens 'gevuld" met Likerttype statements. Aan de hand van eigen ervaringen alsook van die van medewerkers en ook aan de hand van literatuur werd de ziekenhuissituatie doorgelicht op 'privacygevoelige elementen' ten aanzien van de stoelgang. De geformuleerde items werden voorgelegd aan een zevental deskundigen - verplegingswetenschappers, verpleegkundigen, medisch socioloog, medisch psycholoog -, ter beoordeling op formulering, volledigheid van de lijst en relevantie van de items voor het te bestuderen onderwerp. In deze voorbereidingsfase van de constructie van het instrument werden, voomamelijk op geleide van overwegingen van face-validity, alle statements in de cellen opgenomen die relevant leken: 33 statements in cel 1 , en 18 in cel 2 , zodat het vanzelfsprekendheidsaspect van privacybescherming beoordeeld zou worden aan de hand van 51 statements. Het belangrijkheidsaspect werd beoordeeld met behulp van 29 statements, namelijk 14 in cel 3 en 15 in cel 4. De totale PrivacyGevoeligheidsVragenlijst (PGV) bestond zodoende aanvankelijk uit 80 items, verdeeld over de twee 'domeinen' vanzelfsprekendheid en belangrijkheid. Statements over deze twee domeinen werden in de genoemde volgorde aan de respondenten voorgelegd. Deze volgorde is niet willekeurig. Bij een omgekeerde volgorde zou de opsomming van allerlei maatregelen bewust of onbewust van invloed kunnen zijn op hetgeen de respondent als vanzelfsprekend beschouwt.

Ter voorkoming van een response-set is een evenredig aantal items in positieve dan wel in negatieve zin geformuleerd.

\subsection{Vraagstellingen}

Het onderhavige deelonderzoek werd opgezet om vast te stellen of de PrivacyGevoeligheids Vragenlijst (PGV), zoals door ons samengesteld op geleide van de conceptuele analyse, op betrouwbare wijze de privacygevoeligheid meet van ziekenhuispatiënten met betrekking tot de stoelgang. Deze doelstelling geldt zowel de PGV in haar geheel alsook de vier hierboven beschreven dimensies die krachtens de genoemde analyse aan privacygevoeligheid kunnen worden onderscheiden. De betrouwbaarheid wordt aangegeven met behulp van berekening van de interne consistentie: de mate watarin de 
samenstellende delen van het instrument dezelfde karakteristieken meten van thet bestudeerdie fenomeen. Van de uitendelijke PrivacyGevoeligheids Vragenlijst, alsook van de subschalen, Zal inteme consistentie worden aangegeven met behulp van Cronbachis alfa.

Eveneens een doellstelling van dit deelonderzoek was de validiteit vast te stellem van het nieuw geconstrueerde meetinstrument. Het verschijnsel privacygevoeligheid kan, blijkens de conceptuele analyse, worden beschouwd als een veranderlijk fenomeen. Behoefte aan of gevoeligheid voor priwacy kan zich, afhankelijk van uiteenlopende situaties, verschillend voordoen naar gelang iemands leeftijd, geslacht, levenservaring en Jeefsituatie. Omdat de behoefte aan privacy groter kan worden geacht naarmate de te beschermen lichamelijke verrichting (i.c. de ontlasting) gevoeliger ligt voor het individu, dus naarmate de druk om de verrichting voor de privésfeer te reserveren psychologisch en matatschappelijk groter blijkt (Sills, 1986), én ook naarmate het individu minder "gewapend" blijkt tegen de genoemde druk, kan worden verondersteld dat de behoefte aan privacy bij de stoelgang groter is bij vrouwen dan bij mannen, groter bij jongeren dan bij ouderen, groter bij personen uit kleine gezinnen, bij personen met een laag opleidingsniveau, groter bij personen die niet eerder in een ziekenhuis gelegen hebben, met name degenen die niet eerder van een beddepan gebruik hebben moeten maken. Met het oog op construct-validity werden de sociaal-demografische variabelen leeftiju en geslacht, de grootte van het gezin warin men is opgegroeid, het opleidingsniveau, een eerdere, recente ziekenhuisopname, met eventueel daarbij ervaring met het gebruik van de ondersteek, toegevoegd aan de vragenlijst voor de patienten. Met het oog op construct of begripswaliditeit, meer specifiek ten aanzien van de vier theoretisch onderscheiden dimensies van privacygevoeligheid, werd een factoranalyse uitgevoerd op het verkregen onderzoeksmateriaal.

Ter vaststelling van een mate van soortgenootvaliditeit, waarbij wordt nagegaan of er samenhang bestaat tussen de meetresultaten van twee vergelijkbare instrumenten, werd aan de lijst een vraag toegevoegd waamee de respondent gevraagd werd zichzelf te beoordelen, namelijk als wel of niet privacygevoelig. Deze variabele wordt verder als Zelfoordeel in de analyse betrokken (zie Tabel 5.6 e.v.)

\subsection{Opzet en verloop van het onderzoek}

Het onderzoek werd uitgevoerd met behulp van gestructureerde vragenlijsten, op interne afdelingen in twee algemene ziekenhuizen. Criteria voor deelname van patiënten waren:

- goed aanspreekbaar,

- verblijf in het ziekenhuis tussen 5 en 12 dagen,

- opname-indicatie niet een aandoening van het spijsverteringskanaal lager dan het middenrif.

- niet onder invloed van anesthesie vanwege operatie of ingrijpend onderzoek.

Patiënten die aan bovengenoemde criteria voldeden, werden om medewerking aan het onderzoek gevraagd. De aard van het onderzoeksonderwerp, namelijk privacygevoe- 
ligheid, kan de oorzaak zijn van een selectieve nonrespons. Van de 115 benaderde patiënten weigerden zestien medewerking, van wie twaalf patienten in ieder geval niet om teden van het onderwerp van onderzoek; vier patiënten betoonden geen affiniteit met de stoelgang als object van privacygevoeligheid. Zeven patiënten, die onvoldoende aanspreekbaar bleken, werden niet in de populatie opgenomen.

De onderzoekspopulatie was samengesteld zoals weergegeven in Tabel 5.1.

Tabel 5.1 Samenstelling van de onderzoekspopulatie

\begin{tabular}{lccc}
\hline Leettijd & vrouwen & mannen & Totaal \\
\hline $15-19$ & 1 & 2 & 3 \\
$20-29$ & 2 & 2 & 4 \\
$30-39$ & 5 & 5 & 10 \\
$40-49$ & 3 & 6 & 9 \\
$50-59$ & 9 & 10 & 19 \\
60.69 & 14 & 12 & 26 \\
$70-79$ & 12 & 4 & 16 \\
80 en ouder & 4 & 1 & 5 \\
\hline Tolaal & 50 & 42 & 92 \\
\hline
\end{tabular}

De verdeling naar leeftijd komt globaal overeen met die van patiënten op interne afdellingen, zodat deze onderzoekspopulatie althans voor wat de leeftijdsopbouw betreft als representatief mag worden beschouwd (Stijnen, 1988). Van de 92 waren 68 patiënten de afgelopen vijf jaar eerder in een ziekenhuis opgenomen geweest. Van hen hadden 51 patiënten gebruik gemaakt van de beddepan.

Van de 92 patiënten hadden 21 alleen lager onderwijs genoten. Van 76 patiënten lag de opleiding beneden HAVO-niveau.

Contact met de patiënten werd opgenomen door een onderzoeksassistente, die op het punt van 'privacygevoeligheid van ziekenhuispatiënten met betrekking tot de stoelgang' inhoudisdeskundig, en wat betreft interviewen bedreven genoemd mag worden. Toelichting die bij een tevoren gehouden proefonderzoek belangrijk was gebleken, werd tijdens de contactname gegeven. Relevant bleek adstructie over het onderscheid tussen de vanzelfsprekendheid en de wenselijkheid van matregelen omtrent de bescherming van privacy.

Het invullen van de vragenlijst duurde gemiddeld 30 minuten (als de respondent dit zelf verzorgde) tot een uur (indien de interview-vorm moest worden toegepast).

\subsection{PrivacyGevoeligheidsvragenlijst, in vier subschalen}

Op 21 van de 80 items bleken de respondenten een nagenoeg eensluidend antwoord te geven. Daar deze items weinig discrimineren bij het vaststellen van privacygevoeligheid, werden zij niet betrokken bij verdere data-analyse (zie Bijlage 5.1). In Tabel 5.2 worden exemplarisch enkele items getoond. 
Uiteraard blijkt uit de geciteerde voorbeelden grote overeenstemming over aspecten wan privacy bij de stoelgang waarover in brede lagen van de tegenwoordige maatschappij overeenstemming bestaat: men wenst zich afgezonderd, bedekt, in alle rust te ontlasten, óok in het ziekenhuis. Opmerkelijk is echter dat ziekenthuispatiënten het vanzelfsprekend blijken te vinden, dagelijks gevraagd te worden naar de ontlasting. Blijkbaar makt men zich snel vertrouwd met ziekenhuisgewoonten, althans op het punt van de uitscheiding.

Tabel 5.2 Items (exemplarische selectie), niet opgenomen in de data-analyse

Uitsprak

Percentage 'mee eens

Cel 1: "vanzelfsprekendheid van gebruken en gewoonten ter voorkoming van zintuiglijke inbreuk op de privacy'

- Vindt vanzelfsprekend dat, wanneer men op de po(-stoel) gaat, verpleegkundigen nier komen storen met activiteiten die niel rechtsireeks met de sioelgang te maken hebben

- Vindi, voorzover zelfredzaam, na de stoelgang door verpleegkundige geholpen worder niet vanzeifsprekend

Cel 2: "wanzelfsprekendheid van gebruiken en gewoonten ter voorkoming van hinderlike bemoeienis":

- Vindt het wanzelfsprekend dat gevraagd wordt naar problemen met. de ontlasting

- Vindt vanzelfsprekend dat wordt gevraagd hoe vaak per week men ontlasting heeft

- Vindt vanzelfsprekend dal dagelijks wordt gevraagd of men ontlasting heelt gehad

Cel 3: "belangrijkheid van materieel-organisatorische maatregelen tegen zintuiglijke inbreuk op privacy:

- Vindt belangrijk zich op de po(-stoel) te kunnen bedekken (voor zover nodig')

- Vindt belangrijk inname van laxantia te kunnen uitstellen tot na het bezoek

Cel 4: "belangrijkheid van materieel-organisatorische maatregelen tegen minderijke bemoeienis:

- Vindt belangrijk zell te kunnen beslissen of men voor defecatie naar toilet mag

Over de resterende 59 items werden factoranalyses uitgevoend, namelijk in twee groepen gezien het betrekkelijk grote aantal resterende items in verhouding tot het antal respondenten. Achtereenvolgens werd een factoranalyse uitgevoerd over de 32 items betreffende de vanzelfsprekendheid, en over de 27 items betreffende het belang van privacybeschermende maatregelen.

Bij factoranalyse, uitgevoerd op de 32 items betreffende de vanzelfsprekendheid van privacybeschermende maatregelen (ten aanzien van de stoelgang in het ziekenhuis), bleken de eerste vier factoren een eigenwaarde te hebben van 4.79, 2.56, 2.27 en 1.85. De verwachting was dat de items zouden laden op twee factoren, namelijk de vanzelf- 
sprekendheid betreffende van materieel-organisatorische maatregelen alsook van gewoonten en gebruiken. Na rotatie volgens het varimaxcriterium op twee factoren bleek de verdeling van de items zoals in Tabel 5.3.

Tabell 5.3 Factorladingen op twee factoren, na varimaxrotatie

Wragen naar huiselike wc-gewoonten is niet vanzelfsprekend

Vragen naar thuisbezorgoheid is niet vanzelfsprekend

Vragen naar stoelgangregulerende maatregelen is niet varzelisprekend

Niel vanzelfsprekend dat een leerling-verpleegkundige aanwezig is bil een gesprek met verpleegkundige over ontlasting

Vanzelfsprekend is niemand aanwezig bij gesprek met verpleegkundige over ontlasting

Buiten gehoorafsitand wragen naar ontlasting is vanzelfsprekend

Op zaal moetien bliwen voor ontlasting is niet vanzelfsprekend

Niet vanzellsprekend is dat verpleegkundige de ontlasting controleert

Dat tijdens de stoelgang de verpleegkundige een praatje maakt is vanzelfsprekend

Niet vanzelfsprekend dat verpleegkundige bij de stoelgang aileen technische aanwijzingen geeft

Vanzelfsprekend wendt verpleegkundige zich af bij helpen na de stoelgang

Gesprek met zaalgenoten tijdens de stoelgang is vanzelf-

sprekend

Artsenbezoek tijdens de stoelgang is vanzelfsprekend

Zaalgenoten confronteren met ontlastingsgeur is vanzelfsprekend

Het gebruik van een gehorige wo is vanzelfsprekend

Controle doar verpleegkundige tijdens de stoelgang is vanzelfsprekend

Gesprek over ontliasting is vanzelfsprekend

Gestimuleerd worden tot gesprek over stoelgangproblemen is vanzelfsprekend

N.B. Niet op een wan beide factoren laden:

Vanzelfsprekend is het bij de stoelgang telkens dezelfde verpleegkundige te vragen

Zaalgenoot op po(-stoel) zien zitten is vanzelfsprokend

Dat bij de stoelgang niemand achter thet gordijn komt is wamizelsprekend

Vanzelfsprekend is niet alleen het gordin dicht maar ook de kamendeur op slot

Vanzelfsprekend is dat de verpleegkundige vraagt naar stoelgangproblemen

Door verpleegkundige geobserveerd worden in verband met stoelgangproblemen is vanzelfsprekend

Zaalgenoten confronteren met ontlastingsgeluiden is. 
Dat werpleegkundigen voor medische diagnose ontlasting bowaren, ook al kan men dat zelt, is vanzelfsprekend

Regelmatig gesprekken op zala over stoelgang is vanzelfsprekend

Bespreking vam miln ontlastingsproblemen mel anderen. inclusief de arts, is niet vanzelfsprekend

Bespreking vain mijn ontlastingsproblemen met anderen. inclusict huishoudelik personeel, is vanzelsprekend

Ongevraagd geinformeerd worden over aspecten van de stoelgang is niet vanzelfspiekend

Op Factor 1 bleken 11 items te laden - waarvan het merendeel overigens in de formulering een ontkenning bevatte; op Factor 2 laadden 8 items. Beide factoren indiceren vanzelfsprekendheidsaspecten met betrekking tot privacy. Factor 1 bevat hoofdzakelijk items die gewoonten en/of gebruiken betreffen, in Factor 2 gaat het hoofdzakelijk om maatregelen van materieel-organisatorische aard die men kan nemen ter bescherming van privacy. De verdeling der items over de beide factoren komt evenwel niet helemaal overeen met de verdeling van de items over de cellen van de theoretische matrix: enkele items blijken niet eenduidig als 'gewoonten/gebruiken' dan wel als 'maatregelen/initiatieven' te interpreteren.

Bij factoranalyse, uitgevoerd op de 27 items betreffende de belangrijkheid van privacybeschermende maatregelen, bleken de eerste vier factoren een eigenwaarde te hebben van $4.20,2.90,2.28$ en 1.72 . Ook hier werd verwacht dat de items op twee factoren zouden laden, namelijk betreffende de belangrijkheid van materieel-organisatorische maatregelen alsook van gewoonten en gebruiken. Na rotatie volgens het varimaxcriterium op twee factoren, bleken de factoren te laden zoals aangegeven in Tabel 5.4.

Tabel 5.4 Factorladingen op twee factoren, na varimaxrotatie

Items

Fact 1

Fact 2

Belangrijk is de mogelijkheid te hebben deze vragen te beanlwoorden of niet

.57

Belangrijk is de mogellikheid te hebben zélf, indien gewenst, de verpleeghundige in te lichten aver de staelgang

Belangrijk is de mogellikheid te hebben bij de stoelgang de zaalgenoten uit de kamer te sturen

De mogelijkheid te hebber met bed of po(-stoel) weggereden

te worden, is belangrijk

De mogelijktheid te hebben 'niet storen' aan bed te hangen bil onlasting is belangrijk

Zell kunnen beslissen na stoelgang door verpleegkundige geholpen/gewassen te worden is belangrijk

Belangrik is de mogelijkheid te krijgen al of niet over defecatieproblemen te praten met verpleegkundige

Betangrijk is zelf te kunnen aangeven of men hulp wil bij 


\section{stoelglangprobtemen}

Belangruk is de verpleegkundige mogen wagen de andere kan op te kijken

Me kumnen onttrekken aan gesprekker van kamergenoten over ontlasting is belangrijk

Belangrik is problemen met betreking tot de stoelgang in afzondering met de verpleegkumdige te kumnen bespreken

Belangrikk is een expersoonskamer bil stoelgangproblemen

Als ilk op de po(-stoel) zit is het belangrijk de mogelikheid te hebben het bezoek op de gang te laten ontwangen

De mogelikheid habben ne de stoelgang voor frisse luchl te (laten) zorgen is belangrik

De mogelijkheid habben ontlastingsgeludiden verdoezelen (door middel van radio etc. I is belanglijk

Atuld door dezelfde verpleeghundige geholpen/gewassen worden (indien mogelijk) is belangrik

Zeff kunnen bepalen door wie je geholpen/gewassen wordi na de stoelgang is belangrijk

De mogelikheid hebben stoelgamgproblemen steeds met dezelfde verpleegkundige te bespreken is belangrijk

N.B. Net op een van beide factoren laden:

De mogelikkeid hebben deze vragen rustig en in afzondering te beantwoorden is belangrik

Bij geen gevaar voor inkijk is het onbelangrijk de mogelikneid te hebben gordimen te (laten) sluiten

Kunnen kiezen tussen wo die wel of niet op slot kan is belangrijk

Kunnen beslissen de deur wel of niet op slot te doen is be. langriik

Zelf inspectie van faeces mogen utvoeren, waana rapportage aan verpleegkundige, is belangrik

De mogelitheid hebben zélf een monster van faeces te nemen voor laboratorisch onderzoek is belangrijk

De mogellikheid hebben een monster van taeces onopvallend in lle leweren is belangrijk

Op Factor 1 bleken 11 items, op Factor 2 bleken 7 items te laden; 2 items die (iets) lager scoorden dan 40 werden om inhoudelijke reden in de factor opgenomen. Beide factoren indiceren aspecten van belangrijkheid van maatregelen aisook van gewoonten/gebruiken ter bescherming van privacy. Factor 1 bevat items gerelateerd aan privacybescherming door middel van feitelijke isolatie; Factor 2 bevat items die meer het belang van feitelijke controle van de situatie indiceren. Het verschil tussen beide factoren is evenwel niet in alle opzichten evident. De verdeling van de items over de twee factoren komt slechts gedeeltelijk overeen met de verdeling der items over de twee cellen van de theoretische matrix. Blijkbaar maken respondenten geen duidelijk onderscheid tussen feitelijke maatregelen ten behoeve van privacybescherming en het laten gelden 
van gewoonten - het doen gelden van gewoonten kan immers ook als een privacybeschemende maatregel worden opgevat.

De 22 items die niet bleken te laden op én van de vier gedetermineerde factoren, werden niet in verdere analyse betrokken. Op de resterende 37 items werdi nu in én keer een factoranalyse uitgewoerd. De eigenwaarde voor de eerste vier factoren bleek achtereenvolgens $5.54,2.97,2.52$ en 1.86 .

Vatn deze resterende items was de verwachting dat zij, conform de theoretische matrix zouden laden op vier factoren. Na rotatie volgens het varimaxcriterium op vier (exploratief evencens op drie en op twee) factoren, bleek de vierdimensionale oplossing het best te interpreteren. In Tabel 5.5 stalan de factorladingen weergegeven. Alleen factorladingen met een warde van 40 worden bij de interpretatie betrokken.

Tabel 5.5 Factorladingen op de eerste vier factoren na varimaxrotatie

Fact 1 Fact 2 Fact. 3 Fact. 4

De items waren oorspronkelijk opgenomen in:

Cel 1: Vanzelfsprekendheid van regels en normen tegen zintuigelike inbreuk:

- Zaalgenoten confronteren met ontlastings. geuren is vanzelfsprekend

- Vanzelfsprekend is dat de verpleegkundige de ontlasting controleent

- Vanzellsprekend is dat bij stoelgang alleen technische aanwijzingen worden gegeven (cloor de verpleegkundige)

- Vanzelsprekend is dat verpleegkundige zichi afwendi bij helpen na stoelgang

- Doktersvisite tijdens de stoelgang is vanzelfsprekend

- Gesprekken op zaal over stoelgang zijn vanzelfsprekend

Cel 2: Venzelfsprekendheid van regels en normen tegen hinderlijke bemoeienis:

- Gevraagd worden naar huiselike wc-gewoonten is vanzeltsprekend

- Gevraagd worden naar thuisbezorgdheid is vanzellsprekend

- Gevraagd worden naar stoelgang-regulerende maatregelen is vanzelfsprekend

- Leering-verpleegkundige aanwezig bil gesprek met verpleegkundige over ontiasting is vanzelfsprekend

- Vanzelfsprekendheid van lemands aanwezigheid bij gesprek met verpleegkundige over ontlasting

- Buiten gehooratstand vragen naar ontlasting is vanzelfsprekend

- Op zaal moeten blijven voor ontlasting is vanzellsprekend 
De items waren oorspronkelik opgenomen in:

Cel 3: Belang van materieel-onganisatorische maat-

regelen tegen zintuiglike inbreuk:

- Belangrijk is een énpersoonskamer bij defecatieproblemen

- Belangrijk is, indien op po(-stoel) de mogelijkheid te hebben bezoek op de gang te laten ontvangen

- De mogelijkheid hebben voor frisse lucht te (laten) zorgen na de stoelgang is belangriik

- De mogelijkheid hebben ontlastingsgeluiden te verdoezelen (bii voorbeeld door middel van radio etc.) is belangrijk

- Alijd door dezelfde verpleegkundige gehoipen gewassen worden (indien mogelijk) is belangrijk

- Zélf kunnen bepalen door wie geholpen na stoelgang is belangrijk

- De mogelijkheid te hebben bij stoelgang zaalgenoten wit de kamer te sturen is belangrijk

- De mogelijkheid te hebben met bed en po(-stoel) weggereden te worden bij onttasting is belangrijk

- De mogelijkheid te hebben "riet storen" aan bed te hangen bij ontlasting is belangrijk

- Belangrijk is de mogelijkheid te krijgen aliniel over defecatieproblemen te praten mel verpleegkundige

- Belangrijk is verpleegkundige te mogen viagen de andere kant op te kijken

- Belangrijk is in afzondering met verpleegkundige problemen met betrekking tot de stoelgang te kunnen bespreken

- Zélf kunnen beslissen na stoelgang door verpleegkundige geholpen/gewassen te worden is belangrijk

- Me kunnen onttrekken aan gesprek van kamer. genoten over ontlasting is belangrijk

Cel 4: Belang van materieel-organisatorische maatregelen tegen hinderlijke bemoeienis:

- Controle door verpleegkundige tijdens stoelgang is vanzelisprekend

- Gestimuleero worden tot gesprek over stoelgangproblemen is vanzelfsprekend

- Belangrijk is de mogelijkheid te hebben indien men het zelf wenst informatie le geven aan wepleegkundige over stoelgang

Vier factoren konden dus worden geïdentificeerd. De samenstelling van de factoren echter uit de diverse items kwam niet geheel overeen met de wijze waarop de vier cellen van de theoretische matrix van statements waren voorzien. Een zekere verschuiving van items werd geconstateerd tussen de cellen met statements die vanzelfsprekendheid en belangrijkheid weergaven van privacybeschermende maatregelen, alsook tussen cellen waarin items betreffende materieel-organisatorische maatregelen dan wel een 
beroep op gewoonten en ge bruiken. Daarom werden de verkregen factoren ter beoordeling aan collega's verplegingswetenschappers voorgelegd. Overeenstemming werd geconstateend omtrent de volgende interpretatie.

Factor 1 bevat uitspraken over het 'Zintuiglijk contact' tijdens de stoelgang en de belangrijkheid c.q. de vanzelfsprekendheid van maatregelen dit te vermijden. Van deze subschaal bedraagt de interne consistentie Cronbachs $\alpha=.72$.

Factor 2 bevat uitspraken betreffende vanzelfsprekendheid van bemoeienis van derden met iemands stoelgang. De factor wordt dan ook geinterpreteerd als 'Bemoeienis: Deze subschaal, met interne consistentie Cronbachs $\alpha=82$, bestaat uit items waarvan verondersteld werd dat daarmee inderdaad 'vanzelfsprekendheid' gemeten zou worden 'van maatregelen tegen hinderlijke bemoeienis'.

De items in Factor 3 vormen een subschaal met behulp waarvan het belang wordt aangegeven dat men hecht aan feitelijke 'Afzondering'. Deze subschaal, met Cronbachs $\alpha=.74$, bevat items oorspronkelijk geselecteerd ter vaststelling van de belangrijkheid van maatregelen tegen zintuiglijke inbreuk op de privacy.

Factor 4 tenslotte bevat uitspraken over het belang wan controle over de situatie, met name over de uitwisseling van informatie. De factor wordt dan ook geïnterpreteerd als 'Controle'. Deze nieuwe subschaal, met interne consistentie Cronbachs $\alpha=.66$, bevat items die zowel het belang als vanzelfsprekendheid uitdrukken ten aanzien van 'controle'. Toch komt deze factor het meest overeen met de items in de matrix die theoretisch geacht werden "belangrijkheid van maatregelen tegen bemoeienis" tot uitdrukking te brengen.

Concluderend kan worden gesteld dat de Factoren 2 en 3 (dus 'Bemoeienis' en 'Afzondering') in ieder geval duidelijk de deelinstrumenten zijn, ter meting van dimensies van privacy, in overeenstemming met de theoretische matrix. Voor de Factoren $\mathbb{l}$ en 4 (dus 'Zintuiglijk Contact' en 'Controle') geldt dit eveneens. Echter, de bedoelde dimensies van privacy worden met deze subschalen wel gemeten, maar het onderscheid dat theoretisch werd gemaakt tussen vanzelf sprekendheid en belangrijkheid van inbreuk op privacy en van maatregelen tegen die inbreuk, is uit de subschalen verdwenen. Overigens bleek al tijdens de datacollectie dat het onderscheid tussen belangrijkheid en vanzelfsprekendheid voor veel respondenten moeilijk blijvend te hanteren was. De belangrijkste beschrijwende kengetallen worden per subschaal gepresenteerd in Tabel 5.6:

Tabel 5.6 Statistische gegevens van PGV en de subschalen

\begin{tabular}{|c|c|c|c|c|c|}
\hline & $M$ & SD & $\begin{array}{l}\text { Theor. } \\
\text { min.max. }\end{array}$ & $\begin{array}{l}\text { Empir. } \\
\text { min, - max. }\end{array}$ & $\begin{array}{r}\text { Cronbachs } \\
\text { alfa }\end{array}$ \\
\hline 1. Zintuiglikk contacl & 22.0 & 5.94 & $7 \ldots 35$ & $7-33$ & 72 \\
\hline 2. Bemovienis & 27.5 & 8.93 & $10-50$ & $10-50$ & .82 \\
\hline 3. Alzondering & 192 & 5.49 & $6-30$ & $6-30$ & .74 \\
\hline 4. Controle & 25.1 & 5.45 & $7-35$ & $7 \ldots 35$ & .66 \\
\hline 5. Totale PGV & 939 & 16.76 & $30-150$ & $33-128$ & .50 \\
\hline 6. Zelloordeel & 2.4 & .88 & $1-3$ & $1-3$ & 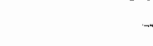 \\
\hline
\end{tabular}

$M=$ gemiddelde

$\mathrm{SD}=$ standaarddeviatie 
Om de onderlinge samenhang tussen de verschillende dimensies van privacygevoeligheid te bepalen, zijn voor de subschalen onderling Pearsons correlatiecoefficienten berekend. Tabel 5.7 biedt een overzicht van de gevonden correlaties, met vermelding van het significantieniveau.

Eveneens in deze Tabel opgenomen zijn de correlaties van de subschalen met de Totaalschaal - waarvan, na vorming ervan door sommeren van de subschalen, de inteme consistentie Cronbachs $\alpha=0.50$ bleek.

Tenslotte zijn in Tabel 5.7 de coëfficiënten opgenomen van de correlaties met de variabele die het zelfoordeel van de patiënten omtrent privacygevoeligheid weergeeft (cf. $\$ 5.3$ ).

Tabel 5.7 Samenhang privacygevaeligheidsschalen onderling en met zelfoordeel

\begin{tabular}{|c|c|c|c|c|c|c|}
\hline & $\begin{array}{l}\text { Zintuiglijk } \\
\text { contact }\end{array}$ & Bemoeienis & $\begin{array}{l}\text { Afzan- } \\
\text { dering }\end{array}$ & Controle & Totalal & $\begin{array}{l}\text { Zelf- } \\
\text { oordeel }\end{array}$ \\
\hline \multicolumn{7}{|l|}{ Zintuigelik } \\
\hline Bemoeienis & & & $42^{* *}$ & $.25 *$ & $.79^{\text {** }}$ & $.47^{* * *}$ \\
\hline Afzondering & & & & $.25 *$ & $.72^{* *}$ & $.59^{* *}$ \\
\hline Controle & & & & & $52^{* *}$ & $.31 *$ \\
\hline Totaa: & & & & & & $644^{* *}$ \\
\hline Zelloondeel & & & & & & \\
\hline
\end{tabular}

$* p \leq 0.01$

${ }^{* *} \mathrm{p} \leq 0.001$

Van een sterke samenhang is sprake tussen de subschalen 'Bemoeienis' en 'Afzondering', hetgeen voor de hand li.jkt te liggen: wil men hinderlijke bemoeienis vermijden, dan neigt men (vanzelfsprekend) tot afzondering.

Ook blijkt er samenhang tussen 'Bemoeienis' en 'Controle'. Ook dit lijkt aannemelijk. Controle wordt, zoals de conceptuele analyse hierboven (in hoofdstuk 2) liet zien, onder meer en in belangrijke mate uitgeoefend als verzet tegen en beheersing van hinderlijke bemoeienis.

Omdat controle van de situatie baat kan vinden bij feitelijke afzondering, lijkt ook de samenhang tussen 'Controle' en 'Afzondering' begrijpelijk.

Tenslotte moet ook de samenhang tussen 'Afzondering" en belang van 'Zintuiglijk contact' alls voor de hand liggend worden beschouwd. Evenwel, het belang dat men hecht aan 'Zintuiglijk contact' blijkt verder met de resterende twee dimensies van privacygevoeligheid niet samen te hangen. Bij gevoeligheid voor privacy (bij de stoelgang) wordt blijkbaar het zintuiglijk contact ervaren als een dimensie onafhankelijk van andere aspecten van privacygevoeligheid.

Sterke samenhang wordt geconstateerd tussen de totale PGV en elk wan de vier subschalen. Eveneens correleren de subschalen met de beoordeling door patiënten zelf van de eigen privacygevoeligheid, terwijl deze zelfbeoordeling tenslotte ook correleert 
met de totale PGV. De gevonden samenhangen dragen bij tot de validering van het ontworpen meetinstrument, namelijk op het punt van begripsvaliditeit respectievelijk soortgenootvaliditeit.

\subsection{Sociaal-demografische context van privacygevoeligheid}

Ter vaststelling van sociaal-demografische invloeden op privacygevoeligheid, werd de samenhang bepaald tussen enerzijds de PGV-totaalschaal, de -subschallen, de zelfbeoordeling, en anderzijds sociaal-demografische gegevens. Het overzicht van Pearsons correlatiecoefficienten wordt gegeven in Tabel 5.8; eventueel extra interactie van variabelen werd vastgesteld met behulp van multiple regressie-analyse.

Privacygevoelig ten aanzien van de ontlasting blijken in onze onderzoeksgroep de wrouwen, voor wat het totaaloordeel betreft. Zij blijken dan met name gevoelig voor privacy waar het 'Afzondering' betreft.

Met de leeftijd blijkt in dit deelonderzoek geen samenhang. Well lijkt de grootte van her gezin van belang. Deze corteleert met de zelfbeoordeling, alsook, meer specifiek, met de subschaal "Zintuiglijk contact". Naarmate de groep waarin men leeft groter is, blijkt men zich bij de stoelgang meer te willen vrijwaren van zintuiglijke inbreuk.

Tabel 5.8 Samenhang privacygevoel igheid en sociaal-demografische gegewens

\begin{tabular}{|c|c|c|c|c|c|c|}
\hline & sekse & $\begin{array}{l}\text { leet- } \\
\text { ilid }\end{array}$ & $\begin{array}{l}\text { groolte } \\
\text { gezin }\end{array}$ & $\begin{array}{l}\text { oplei } \\
\text { dings- } \\
\text { niveau }\end{array}$ & $\begin{array}{l}\text { exerder } \\
\text { zieken- } \\
\text { hulis- } \\
\text { opmame }\end{array}$ & $\begin{array}{l}\text { eercler } \\
\text { po-gebruik }\end{array}$ \\
\hline $\begin{array}{l}\text { Zintuiglijk } \\
\text { contact }\end{array}$ & -12 & -.11 & $22^{n}$ & $-22^{*}$ & -.15 & -.13 \\
\hline $\begin{array}{l}\text { Bemoeirem } \\
\text { nis }\end{array}$ &.- .14 & -.05 & .06 & $25 *$ & $21 * 1$ & $25^{k *}$ \\
\hline $\begin{array}{l}\text { Afon- } \\
\text { dering }\end{array}$ & $-.26^{\text {vit }}$ & -.03 & .16 & $20^{* 1}$ & .03 & .12 \\
\hline Controle & $\therefore 03$ & -.03 & 10 & .04 & -.08 & -.03 \\
\hline Tolat & $21 *$ & -08 & $20^{1}$ & 13 & .04 & .11 \\
\hline $\begin{array}{l}\text { Zell- } \\
\text { ocidoel }\end{array}$ & $-.20^{\mathrm{ki}} 1$ & -.08 & $.24 *$ & 14 & .17 & .17 \\
\hline
\end{tabular}

Met het opleidingsniveau hangen twee van de vier PGV-subschalen samen. De hoger opgeleiden blijken gevoeliger op het punt van bemoeienis; de lager opgeleiden blijken meer behoefte aan privacy te hebben ten aanzien van zintuiglijk contact. Bij de stoelgang gezien, gehoord en geroken worden vormt, in de terminologie van Elias 
(1982), een "pijnlijkheidsdrempet" die blijkbaar lager wordt naarmate men hoger is opgeleid. Het onderwijs als schaamte- en gêneverlagende factor?

Privacygewoligheid blijkt, in haar totaliteit dan wel op onderdelen gemeten, niet te correleren met een eerdere ziekenhuisopname als zodanig. Bij eerder gebruik van de ondersteek echter blijkt men gevoelig op het punt van bemoeienis.

Concluderend kan men stellen dat gevoeligheid voor privacy (met betrekking tot de stoelgang), in haar totaliteit dan wel op onderdelen, significante samenhang vertoont met enkele sociaal-demografische variabelen. Privacygevoeligheid blijkt als verschijnsel afhankelijk van omstandigheden, hetgeen zijn consequenties kan hebben voor onstandigheden die sterk onderhevig zijn aan veranderingen en waarin privacygevoeligheid belangrijk kan zijn, zoals de gezondheidszorg.

\subsection{Discussie en conclusies}

5.8.1 Kunnen door middel van een (gestandaardiseerd) meetinstrument ter vaststelling van privacygevoeligheid van ziekenhuispatiënten ten aanzien van de stoelgang de theoretische dimensies van het begrip 'privacygevoeligheid met betrekking tot de stoelgang' empirisch worden onderbouwd? Op deze initiële vraag kan nu een voorlopig antwoord worden gegeven. De matrix met daarin de bedoelde theoretische dimensies ontstond door relateren van twee vormen van inbreuk op privacy aan twee wijzen van privacybescherming; zowel de vormen van inbreuk alsook de privacybeschermende maatregelen waren aangereikt door de vakliteratuur. Beoogd werd "gevoeligheid voor privacy' te meten door respondenten statements voor te leggen over het gewicht dat men hecht aan vanzelfsprekendheid dan wel belangrijkheid van privacybeschermende maatregelen tegen de beide soorten inbreuk op privacy. Zoals wellicht al blijkt uit de relatief moeizame constructie wan voorafgaande zin, was de intentie van de onderzoeker gedetailleerd en (dus) complex. Té gedetailleerd en té complex, zoals bleek bij factoranalyse van de gebruikte statements. Items bleken te verschuiven tussen enkele van de vier cellen van de matrix. Met het wegvallen van items, die ofwel niet discrimineerden ofwel niet laadden op een van de vier uiteindelijke factoren - van de oorspronkelijke 80 bleven er 30 statements over -, verdwenen ook nuanceringsmogelijkheden. Het onderscheid, dat overigens door de respondenten als moeilijk hanteer" baar was ervaren, tussen wanzelfsprekendheid en belangrijkheid van privacybeschermende matregelen, verdween grotendeels uit de interpretatie van de factoren. Eveneens verdween enigszins het (theoretisch goed te duiden) onderscheid tussen actief, met behulp van maatregelen of initiatieven gerealiseende privacybescheming, en het meer passieve zich verlaten op gewoonten en gebruiken. Tenslotte bleek ook het onderscheid niet consequent te handhaven - hoewel het ook niet helemaal verdween tussen "zintuiglijke inbreuk" en "hinderlijke bemoeienis": wie zich hinderlijk bemoeit met iemands intieme aangelegenheden, heeft vaak temminste visueel contact met de persoon op wiens privacy imbreuk wordt gedaan.

Wat de vier factoren uiteindelijk overhielden aan betekenis, kan geacht worden de kernachtige weergave te zijn van de vier op basis wan theoretische analyse onderseheiden dimensies van 'privacygevoeligheid met betrekking tot de stoelgang': 
Zintuiglijk contact meet de mate waarin men zintuigelijk contact bij de stoelgang wanzelfsprekend vindi;

Bemoeienis meet de mate waarin men aanwezigheid bij of bemoeienis met de stoelgang vanzelfsprekend vindt;

Afzondering meet de mate waarin men feitelijke afzondering bij de stoelgang belangrijk vindf;

Controle meet de mate waarin men het belangrijk vindt controle te hebben over de gehele (stoelgang-) situatie, met name over de informatie dienaangaande.

De totale PrivacyGevoeligheids Vragenlijst alsook de vier subschalen beschikken over acceptabele interne consistentie, zodat mag worden gesteld dat het gevormde meetinstrument op dit punt voldoende betrouwbaar is.

Aan het aspect van intersubjectiviteit zou in vervolgonderzoek met name aandacht besteed moeten worden. Ditzelfde geldt eveneens voor het aspect van stabiliteit: 'privacygevoeligheid' is een zowel synchroon als diachroon (sterk) wisselend fenomeen gebleken.

5.8.2 De stoelgang blijkt voor sommigen gerelateerd aan gevoelens van schaamte (cf. hoofdstuk 4), namelijk schaamte om bij de ontlasting gehoord en/of geroken te worden. In het ziekenhuis (cf. hoofdstuk 6) blijkt problematiek omtrent de stoelgang voor met name de patiënten die van de po gebruik maken, gerelateerd aan gevoelens van schaamte omtrent de ontlasting, alsook aan privacybehoefte in contact met bezoekers en medisch en verplegend personeel. Inzicht verkrijgen in de mate van privacygevoeligheid bij de stoelgang lijkt voor de verpleegkundigen dus alleszins nuttig en relevant.

Met behulp van de PrivacyGevoeligheidsVragenlijst wordt inzicht verkregen in de mate van die specifieke privacygevoeligheid. Weliswaar kan dit inzicht, dat wordt verworven aan de hand wan een lijst van 30 vragen, eveneens worden verkregen door de patiënt eenvoudig te wragen naar zijn eigen oordeel. Maar in privacygevoeligheid bij de stoelgang bleken vier dimensies te onderscheiden, waarop patiënten in verschillende mate privacygevoelig bleken. De PrivacyGevoeligheidsVragenlijst kan inzicht verschaffen in de mate waarin men gevoelig is voor de onderscheiden dimensies van privacy bij de stoelgang.

Rest nog de vraag of de 30 items tellende PGV niet gereduceerd zou kunnen worden tot een handzamer vragenlijstje. Misschien de patiënten vragen naar hun zelfoordeel omtrent de vier onderscheiden dimensies van privacygevoeligheid? 


\section{Bezorgdheid omtrent de stoelgang in het ziekenhuis}

\subsection{Onderzoeksvraagstellingen}

Bezorgdheid omtrent de stoelgang van patiënten op de verpleegafdeling is over het algemeen bekend bij de verplegenden. 'I didn't mind the operation or anything at all about the hospital except the bedpan', is volgens Benton, Brown \& Rusk (1950) een van de meest gehoorde commentaren van patiënten na ontslag uit het ziekenhuis. Het deelonderzoek waarvan in onderhavig hoofdstuk verslag wordt gedaan, had als doelstelling omvang en aard van deze bezorgdheid nader te bepalen.

Problemen met betrekking tot de stoelgang liggen voor wie wordt opgenomen in het ziekenhuis, eigenlijk voor de hand. Veranderingen in het defecatiepatroon zijn bekend, worden soms min of meer verwacht in omstandigheden waarin iemand verandert van leeforngeving. Op vakantie, op reis of bij langere af wezigheid van huis ervaart menigeen veranderingen in het ontlastingspatroon.

Als probjemen met betrekking tot de stoelgang in het ziekenhuis kunnen uiteenlopende aspecten van de uitscheiding worden aangemerkt. Als problematisch kan datgene worden beschouwd dat door de patiènt als zodanig wordt ervaren. Problematisch is hetgeen de patiënt zorgen baart: "worry and concern" genoemd in het onderzoek waarvan het onderhavige als replicatie-onderzoek werd opgezet (Wright 1974, Van der Bruggen 1985; cf. $\$ 6.3$ ).

De eerste onderzoeksvraag luidt dan ook:

In welke mate zijn patiënten in een algemeen ziekenhuis bezorgd omtrent de stoelgang?

Het vóorkomen van bezorgdheid over de stoelgang op de afdeling werd bevestigd door onderzoek van Wright (1974), Mauchamp (1982), Van der Bruggen (1985) en Van der Kooij (1986). Door deze auteurs werd tevens een aanzet gegeven tot nadere beschrijving van de aard van de problematiek. Die bleek bepaald door het optreden van obstipatie en gerelateerd aan enkele persoons- en gedragskenmerken, alsook enkele factoren de ziekenhuisomgeving en de zorgverlening betreffende.

Een ernstige ziekte of aandoening, die meestal de aanleiding zijn tot ziekenliuisopname, zijn vaak gebeurtenissen die diep ingrijpen in iemands bestaan. De bedreiging die daarvan kan uitgaan, wordt mogelijkerwijs versterkt door de opname in het ziekenhuis, eveneens een ingrijpende gebeurtenis. Een dubbele "desintegratie" kan plaatsvinden: die van de persoon ten opzichte van zijn eigen leefwereld. maar ook ten 
opzichte van het eigen lichaam (Van der Bruggen, 1977). Het menselijk lichaam, dat zich bij zickte kan gaan gedragen als een 'vreemde', een 'verrader' (Buytendijk, 1965), kan verstek laten gaan. Reacties als diarree of obstipatie zijn dan aannemelijk. Deze kunnen de wankele lichamelijke gesteldheid, de defecte gezondheidsbeleving op hun beurt nadelig beinvloeden.

Allereerst dus lijken veranderingen in het lichamelijk functioneren evident, vervolgens is er sprake van gevoelsmatige reacties op de veranderende processen en situaties. Enkele andere onderzoeksvragen worden hieruit afgeleid:

Welke veranderingen treden op in iemands defecaitepatroon na opname in een algemeen ziekenhuis?

In hoeverre zijn veranderingen in het defecatiepatroon in het ziekenhuis gerelateerd aan de genoemde bezorgdheid?

Welke eventude andere factoren staan in verband met de bezorgdheid omtrent de ontlasting op de verpleegafdeling?

\subsection{Bezorgdheid omtrent de stoelgang in het ziekenhuis: mogelijke determinanten}

Bezorgdheid omtrent de stoelgang kan in relatie gezien worden met een aantal factoren. Invloed op de betreffende problematiek lijkt aannemelijk van sociaal-demografische kenmerken, alsook van gedrags- en belevingskenmerken gerelateerd aan de situatie van de patiënt vóór ziekenhuisopname, vervolgens van gedrags- en belevingsvariabelen gerelateerd aan het ziekenhuisverblijf, en tenslotte van variabelen die meer rechtstreeks met de concrete verpleegkundige zorgverlening verband houden. In de, overigens schaarse, literatuur over bezorgdheid van ziekenhuispatiënten omtrent de stoelgang worden inderdaad deze factoren van invloed min of meer gedetailleerd beschreven (Wright 1974, Mauchamp 1982, Dassen 1984, Van der Bruggen 1985, Engels 1985, Van der Kooij 1987). Maar vanuit deze studies wordt geen adequaat verklaringsmodel geboden voor gericht onderzoek van de defecatieproblematiek in het ziekenhuis. Daarom werd, uitgaande weliswaar van gegevens uit de genoemde literatuur maar eveneens afgaande op de zorgkundige ervaring van velen bij de hier gerapporteerde deelonderzoeken betrokken, de bestudeerde problematiek exploratief benaderd. Derhalve wordt eerst nagegaan welke mogelijke determinanten benoemd kunnen worden als eventuele onafhankelijke variabelen bij "bezorgdheid omtrent de stoelgang in het ziekenhuis".

Door Wright (1974) werd een relatie geconstateerd tussen 'worry and concern' en het geslacht van respondenten. Gezien de resultaten gerapporteerd in bovenstaande hoofdstukken 3, 4 en 5, is het aannemelijk de sociaal-demografische variabelen geslacht en leeftijd te beschouwen als mogelijk van invloed op bezorgdheid over de stoelgang in het ziekenhuis.

In de literatuur wordt over het algemeen de relatie vastgesteld tussen bezorgdheid omtrent de uitscheiding en het gebruik van de beddepan (Wright 1974, Van der Bruggen 1985, Van der Kooij 1987). Ook deze variabele mag dus gelden als een van de mogelijke 
determinanten van bezorgdheid omtrent de stoelgang.

Met overige factoren van invloed zijn vanuit de literatuur geen relaties bekend. Exploratief kunnen de volgende mogelijke determinanten in overweging worden genomen.

De withuizigheid van personen, i.c. de ziekenhuisopname, werd hierboven aangemerkt als mogelijk van inwloed op defecatieproblemen in het zickenhuis. Gerelateerd aan het idee van uithuizigheid is het feit of de patiènt vertrouwd is, of niet, met de ziekenhuissituatie: voor het eerst in het ziekenhuis verblijven wordt daarom als mogelijke aanleiding tot bezorgdheid gezien.

De aard van ziekte of aandoening, eveneens aangemerkt als mogelijk van invloed op de hier bestudeerde problematiek, wordt nader gespecificeerd anan de hand van de affdeling waar deelnemers aan dit onderzoek zijn opgenomen, namelijk op interne dan wel op chirurgische of orthopedische afdelingen.

Tenslotte kan ook het type ziekenhuis (al dan niet academisch) waqrin de patiènt wordt verpleegd als determinant in deze worden beschouwd. Over de aard van deze invloed zijn overigens amper precieze verwachtingen te formuleren. Behandeling en verpleging in het academisch ziekenhuis kunnen als geavanceerder dan in het algemene ziekenhuis worden gekenmerkt: de intensievere aandacht voor de patiènt kan resulteren in extra aandacht voor de alledaagse levensbehoeften, maar kan daar ook juist aan voorbijgaan.

Kortom: enkele sociaal-demografische variabelen worden in dit onderzoek als mogelijke determinanten van defecatieproblemen in het ziekenhuis aangemerkt:

1. de lleeftijd van de respondenten,

2. geslacht,

3. aard van de ziekte of aandoening, $c . q$. specialisme van de afdeling waar men wordt verpleegd, i.c. de interne afdeling dan wel de orthopedisch-chirurgische afdeling,

4. het type ziekenhuis waar men is opgenonen, dat wil zeggen het academisch of het niet-academisch ziekenhuis,

5. al dan niet voor het eerst in het ziekenhuis zijn opgenomen,

6. gebruik van po dan wel van po-stoel of toilet.

Vervolgens kunnen, eveneens exploratief, enkele kenmerken van gedrag of beleving thuis worden beschouwd als nogelijk wan invloed op bezorgdheid omtrent de stoelgang. Gebruikelijk is het, deze bezorgdheid in verband te zien met lichamelijk ongemak bij de stoelgang, als pijn bij het persen, kloofjes, aambeien.

Eveneens kunnen uitscheidingsproblemen worden verwacht bij degenen die stoelgangregulerende matregelen treffen. Deze bestaan waak in het gebruk van laxerende middelen, hetzij medicijnen, hetzij natuurlijke laxerende produkten, hetzij voeding met laxerende (bij)werking.

Op veranderingen in het nomale levensritme, als ge volg van ziekenhuisopname, kan door patiënten persoonlijk verschillend worden gereageerd. Indien men deze veranderingen, bijvoorbeeld in het voedings- of in het slaappatroon, als problematisch ervaart, kan men relaties veronderstellen met problemen omtrent de defecatie, die tenslotte evenzo tot de (min of meer) dagelijkse levenswerrichtingen behoort. Om intrinsieke redenen worden in dit deelonderzoek twee wijzigingen in het dagelijkse 
leefpatroon nader bestudeerd. De lichaamsbeweging, in het ziekenhuis mogelijkerwijs sterk gereduceerd, kan door sommigen belangrijk voor de normale stoelgang worden geacht. En vervolgens is het op de verpleegafdeling zelden mogelijk toiletrituelen te praktiseren waarmee de defecatie thuis gepaard kan gaan: roken, lezen, muziek beluisteren, tevoren eten of drinken, het nemen van bepaalde hygiënische maatregelen, enzovourt.

Kortom: enkele gedraggi en belevingsuariabelen thuis worden in dit deelonderzoek als eventuele determinanten van defecatieproblematiek beschouwd, namelijk:

1. lichamelijk ongemak bij de stoelgang, bijvoorbeeld last van aambeien,

2. gebruik maken van laxerende middelen,

3. lichaamsbeweging belangrijk voor de stoelgang,

4. gehechtheid aan de toiletrituelen van thuis.

Vervolgens zijn enkele variabelen te noemen, gegroepeerd tot gedrags- en belevingsvariabelen in het ziekenhuis. Door Wright (1974) werd een verband vastgesteld tussen 'worry and concern' en wijzigingen die zich na ziekenhuisopname voordoen in het ontlastingspatroon zelf, met name ten aanzien van de frequentie en de consistentie van de ontlasting.

Hier doet zich echter een verschil voor ten opzichte van de twee hierboven beschreven clusters van variabelen: een gewijzigd defecatiepatroon kán zowel aanleiding tot, alsook gevolg zijn van stoelgangproblemen. Datzelfde geldt voor de overige variabelen binnen dit cluster, bijvoorbeeld voor het fenomeen van gefixeerdheid, dat wil zeggen de grote betrokkenheid van sommige patiënten op het proces en de produkten van de eigen stoelgang. Mocht er van een relatie sprake zijn tussen deze betrokkenheid en defecatieproblematiek in het ziekenhuis, dan is beïnvloeding misschien wederzijds.

Behoefte aan privacy en gevoelens van schaamte als mogelijke factor van invloed op stoelgangproblemen, zijn eveneens bekend (Van der Bruggen, 1985). Ook deze kunnen zowel aanleiding tot alsook gevolg zijn van de genoemde problemen.

Kortom: in de categorie gedrags-en belevingsvariabelen in het ziekenhuis, waaraan, in tegenstelling tot de overige clusters variabelen, een notie van wederkerigheid lijkt verbonden, worden als eventuele determinanten van stoelgangproblematiek in het ziekenhuis de volgende variabelen opgenomen:

1. wijziging(en) in het defecatiepatroon in het ziekenhuis ten opzichte van thuis,

2. gefixeerdheid of grote betrokkenheid van patiënten op proces en produkten van de stoelgang,

3. gevoelens van schaamte ten opzichte van (aspecten van) de stoelgang,

4. privacygevoeligheid in intermenselijke verhoudingen,

5. wenselijkheid van materiële afzondering, zowel bij po-als bij wc-gebruikers.

Een vierde groep mogelijke determinanten van bezorgdheid over de stoelgang in het ziekenhuis bestaat uit variabelen gerelateerd aan de zorgverlening. Immers, er mag worden aangenomen dat verpleegkundige interventies van invloed zijn op ontlastingsproblemen: ten voordele maar eventueel ook, indien niet of niet goed uitgevoerd, ten nadele van de patiènt.

Op de eerste plats kan gedacht worden aan maatregelen van materieel-technische 
aard die de stoelgang van de patiènt vergemakkelijken. De noodzakelijke sanithire voorzieningen moeten getroffen zijn: wamneer patiènten te lang moeten wachten voor de beddepan wordt verstrekt, danwel omdat er én we zou zijn op een totaal van 45 patienten, ontstaan er licht problemen. Van materieel-technische aard is de verpleegkundige interventie waarbij de patiènt stabiel op de ondersteek wordt gezet, zonder gevaar voor omvallen, wegglijden, spierkrampen , bevuilen van het bed of van de kleding.

Vervolgens dient gedacht te worden aan de adequate hygiënische verzorging van de patiënt: is voldoende papier beschikbaar, kan men de handen wassen, is er na gebruik van ondersteek of toilet gelegenheid de anaalstreek te wassen?

Tenslotte dient men maatregelen te kunnen nemen ter bescherming van enige privacy. Belangrijke voorwaarden daarbij zijn: niet gezien, niet gehoord en niet geroken worden. Op de verpleegafdeling lijkt 'niet geroken worden" althans enigszius realiseerbaar met behulp van simpele middelen, overigens geheel gelegen in Nightingaliaanse traditie: voldoende luchtverversing realiseren.

Kortom: enkele aan de zorgverlening gerelateerde variabelen, in dit onderzoek te beschouwen als eventuele determinanten van defecatieproblematiek, zijn:

1. materieel-technische voorwaarden, i.c. een stabiele 'zit" op de ondersteek,

2. materieel-hygiënische voorwaarden, i.c. de handen kunnen wassen na gebruik van de beddepan,

3. privacy-beschermende voorwaarden, i.c. voldoende luchtverversing.

De veronderstelde samenhang tussen de onderscheiden clusters determinanten wordt in Figuur 6.1 als volgt geillustreerd.

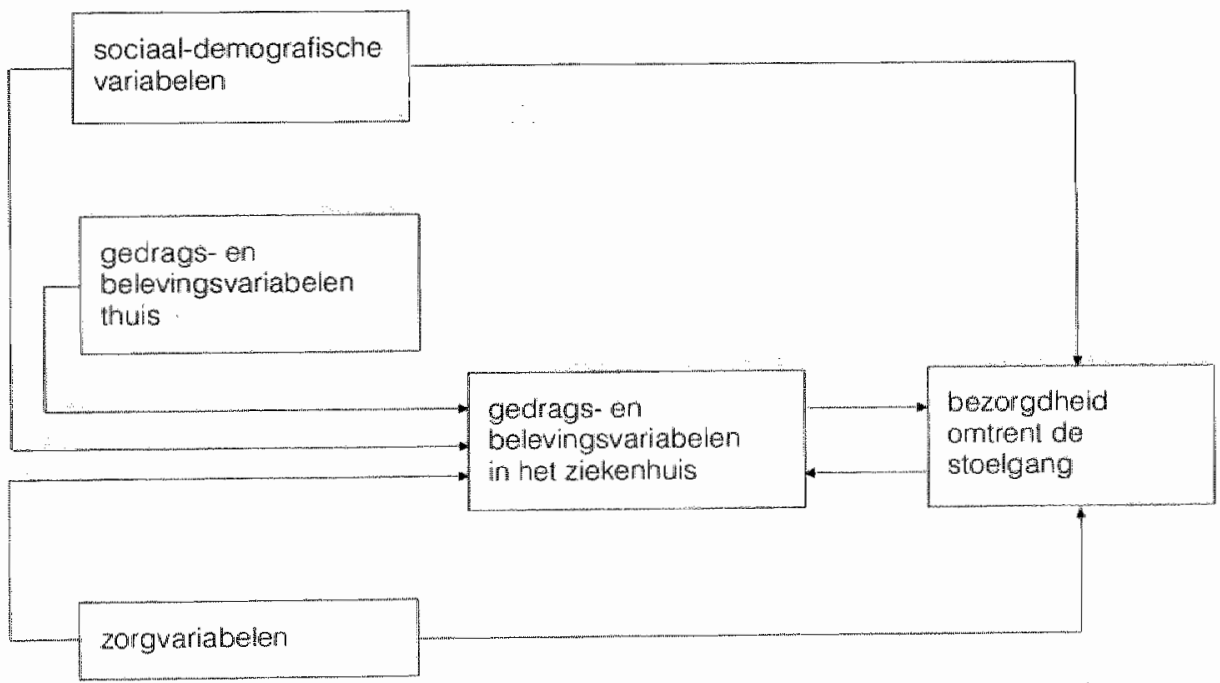

Figuur 6.1 Clustering mogelijke determinanten van 'bezorgdheid omtrent de stoelgang' 


\subsection{Opzet en methode van onderzoek}

Het onderhavige deelonderzoek werd opgezet als een replicatie van het al angehaalde onderzoek wan Wright (1974). Samenwerking met een research-projectgroep in het verpleegkundig hoger beroepsonderwijs resulteerde in uitbreiding van de onderzoeksvragen zoals hierboven vermeld (Van der Bruggen 1984, 1985, Loor-Netjes 1985). Als herhaling en verbreding van een bestaand verpleegkundig onderzoek beoogt het hier gerapporteerde deelonderzoek dus consolidering en stabilisering, tevens uitbreiding van bestaande kennis in de verpleegkunde (Conelly, 1986).

De onderzoekspopulatie werd samengesteld op geleide van Wrights selectiecriteria. Patienten waren:

- ouder dan 11 jaar,

- goed anspreekbaar,

- in het rekenihuis tussen 5 en 12 dagen,

- niet opgenomen vanwege een aandoening van het spijsverteringskanaal lager dan het middenrif,

- niet onder invloed wan anesthesie vanwege operatie of ingrijpend onderzoek.

Daarenboven waren/was in het replicatie-onderzoek

- alle leeftijdsgroepen gelijkelijk vertegenwoordigd,

- evenveel mannen en vrouwen opgenomen,

- 40\% van de patiënten voor de eerste keer (of langer geleden dan vijf jarar) in een ziekenhuis opgenomen.

- 50\% van de patiènten op her moment van het interview bekend met het gebruik van die ondersteek.

Voor verbreding van de kennis omtrent bezorgdheid omtrent de stoelgang in het ziekenhuis werden niet alleen, zoals in Wrights onderzoek, patiënten geselecteerd van interne, maar ook van chirurgische en orthopedische afdelingen, dat will zeggen zowel van de "niet-snijdende" als van de "snijolende specialismen".

In het replicatie-onderzoek participeerden twee algemene en twee academische ziekenhuizen, gelegen in verschullende gedeelten van Nederland, namelijk respectievelijk in Hilversum en Gorcum, Uirecht en Maastricht.

De samenstelling van de onderzoekspopulatie is weergegeven in Tabel 6.1.

Van de 160 patiënten waren er 115 opgenomen in een academisch ziekenhuis. Van alle deelnemers makten 75 gebruik van de po in bed. 78 van de 160 participanten werden verpleegd op interne afdelimgen.

De patienten werden, over het algemeen na overleg tnet de hoofdverpleeglkundige, verzocht aan het onderzoek deel te nemen, nadat hen mondeling en/of schriftelijk informatie was verstrekt over het doel en de procedure van het onderzoek. Van de 190 benaderde patiênten weigerden er 30 deelname aan het onderzoek, van wie de meesten on redenen van vermoeidheid of gebrek aan belangstelling voor het onderwerp.

De 160 resterenden werden elk apart geïnterviewd, onder voor de respondenten de meest gunstige omstandigheden wat tijd en lokaal betreft. De interviewers, die soms 
alleen, soms paarsgewijs de respondenten onderwroegen, gebruikten daarbij voorgestructureende enquêtelijsten.

Met het onderzoek van Wright als uitgangspunt werd de vragenlijst toegespitst. behalve op demografische kenmerken van de populatie, ook op het nomale ontlasfingspatroon zowel thuis als in het ziekenhuis, vervolgens op wijzigingen c.q. afwijkingen van defecatiepatroon en -produkten in het ziekentivis, en tenslotte op factoren van invloed op de defecatieproblemen.

Tabel 6.1 Onderzoekspopulatie bij het replicatie-onderzoek

\begin{tabular}{|c|c|c|c|c|}
\hline & Geslacht: & mannen & vrouwen & Totaal \\
\hline \multicolumn{5}{|c|}{ Leeftijdsklassen: } \\
\hline 15 - 19 jear: & & 4 & 7 & 11 \\
\hline $20-29$ & & 10 & 8 & 18 \\
\hline $30-39$ & & 11 & 11 & 22 \\
\hline $40-49$ & & 18 & 10 & 28 \\
\hline $50-59$ & & 10 & 17 & 27 \\
\hline $60-69$ & & 15 & 12 & 27 \\
\hline$\geq 70$ jaar: & & 12 & 15 & 27 \\
\hline Totaal & & 80 & 80 & 160 \\
\hline
\end{tabular}

\subsection{Operationalisering van de variabelen}

\subsubsection{Afhankelijke variabele: bezorgdheid omtrent de stoelgang}

Over de bezorgdheid omtrent de stoelgang werden de respondenten enkele directe vragen gesteld. Geïnformeerd werd naar de bezorgdheid omtrent de stoelgang thuis, alsook naar de be-zorgdheid op de verpleegafdeling in vergelijking met de bezorgdheid omtrent de stoelgang thuis. Als bezorgdheid omtrent de stoelgang in het ziekenhuis werden alle mensen aangemerkt die zelf aangaven dat ze bezorgd waren. Concreet betekende dit dat als zodanig die respondenten werden aangemerkt die in hef ziekenhuis meldden bezorgder te zijn dan thuis, alsook degenen die, indien thuis al bezorgd, op de verpleegafdeling ongeveer even bezorgd waren: in Tabel 6.2 de cursief gedrukte acutallen, dus in totaal 65 respondenten $(=41 \%)$; de overige 95 respondenten worden als in het ziekenhuis niet-bezorgd omtrent de stoelgang beschouwd.

\subsubsection{De onafhankelijke variabelen}

De meeste onafhankelijke variabelen werden gemeten door respondenten enquêtevragen voor te leggen: meestal én vraag per onderwerp (bijvoorbed ld: Bent u gehecht aan wc-rituelen thuis? Vindt u lichaamsbeweging belangrijk voor een voorspoedige stoelgang?)

Met betrekking tot enkele variabelen, zoals de groté betrokkenheid van patiènten op proces en produkten van de uitscheiding, of de gevoeligheid voor privacy en gevoelens van schaamte, werden verschillende vragen gesteld. Aan de hand van vastgestelde in- 
Tabel 6.2 Vóorkomen var 'bezorgdheid omtrent de stoelgang' in het ziekenhuis ten opzichte van thuis

\begin{tabular}{|c|c|c|c|c|}
\hline \multirow[t]{2}{*}{ Bezorgdheid } & \multicolumn{3}{|c|}{ Thuis: } & \multirow[b]{2}{*}{ Totaal } \\
\hline & nee & ja & n.b. & \\
\hline \multicolumn{5}{|l|}{ In het ziekenthuis: } \\
\hline $\begin{array}{l}\text { meer: } \\
\text { ongeveer hetzellde: } \\
\text { minder: } \\
\text { niet beantw: }\end{array}$ & $\begin{array}{r}37 \\
80 \\
2 \\
11\end{array}$ & $\begin{array}{r}14 \\
12 \\
2 \\
1\end{array}$ & $\begin{array}{l}1 \\
0 \\
0 \\
0\end{array}$ & $\begin{array}{r}52 \\
92 \\
4 \\
12\end{array}$ \\
\hline Totaal & 130 & 29 & 1 & 160 \\
\hline
\end{tabular}

N.B. De cursief gedrukle getallen vormen te zamen de populatie patiënten met 'zorgen omtrent de stoelgang'.

terne consistentie tussen de antwoorden op die vragen, werden nieuwe variabelen samengesteld.

a. Sommige patiënten blijken in het ziekenhuis betrokken op het proces en de produkten wan de stoelgang. Gevraagd naar verschillende aspecten van die aandacht, antwoordden de respondenten als in Tabel 6.3.

Tabel 6.3 Betrokkenheid op de stoelgang $(n=160)$

Items:

$\%$ instemmende antwoorden

1. In het ziekenhuis meer aandacht voor de stoelgang

2. De stoelgang is meer anderwerp van gesprek

3. Let beter (dan thuis) op de tussempozen

4. Kijkt aandachtiger (dan thuss) naar ontasting

Item 2 werd om inhoudelijke reden niet opgenomen in de nieuw te wormen variabele: 'betrokkemheid' van de patënt op (proces en produkten van) de stoelgang. De inteme consistentie van deze nieuwe variabele bedraagt Cronbachs $\alpha=.69$.

b. Finkele viagen werden gesteld betreffende gevoelens van schamte bij de stoelgang. Desgevraagd antwoordden de respondenten die de po gebruikten, als in Tabel 6.4. De nieuw gevornde variabele, "schaamte" in verband met de stoelgang (bij po-gebruikers), bezit een interne consistentie van Cronbachs $\alpha=.77$.

c. Evenzo werden de vragen die betrekking hadden op privacygevoeligheid van de patiënten, gegroepeerd tot een nieuwe variabele. Op vragen daaromtrent, eveneens aan po-gebruikers gesteld, werd geantwoord als angegeven in Tabel 6.5 . 
Htems:

$\%$ instemmendie antwoorden

1. heeflt hinder van eigen stanik

2. heeft hinder van eigen geluiden

3. vindt later oprumen van ontlasting hinderlijk

Tabel 6.5 Privacygevoeligheid in interpersoonlijk contact $(n=75)$

Iterns:

$\%$ instemmende antwoorden

Patienten beoordelen zichzelf 'privacy-gewoelig' to. w:

1. medepatienten

2. verptegenden

3. diensten

4. (para)medici

5. bezoekers

De nieuw gevormde variabele, privacygevoeligheid in interpersoonlijk contact (verder kortweg 'contact-privacy' genoemd), bezit een interne consistentie van Cronbachs $\alpha=85$.

d. Met betrekking tot de wenselijkheid van feitelijke afzondering tijdens de ontlasting, werden aan de gebruikers van po en van wc verschillende vragen gesteld.

De vragen voorgelegd aan de po-gebruikers, werden beantwoord als weergegeven in Tabel 6.6. Een vraag waarop met grote eenstemmigheid (97\%) werd geantwoord, namelijk of men bij po-gebruik te weinig privacy geniet, werd niet in de factorstructuur betrokken. De nieuw gevormde variabele, privacygevoeligheid van po-gebruikers, bezit een interne consistentie van Cronbachs $\alpha=.64$.

Tabell 6.6 Privacygevoeligheid van po-gebruikers $(n=75)$

items:

$\%$ instemmende antwoorden

1. het bed afschermen is belangrijk

2. po-gebruik is een inbreuk op de privacy

3. zaalgenoten weg bij po-gebruik is belangrijk

De vragen aan de wc-gebruikers gesteld, werden over het algemeen eensluidend beantwoord, zodat die vragen als niet-dis-criminerend uit de factorstructuur werden weggelaten. Afwezigheid bij de stoelgang van ongewenste personen wordt belangrijk gevonden $(100 \%)$, het slot op de wc-deur vindt men belangrijk ( $96 \%$ ). De twee viragen weergegeven in Tabel 6.7 lijken enigszins te discrimineren. Zij correleren significant (Pearsons correlatie $=.44, \mathrm{p}=.000$ ); wc-gebruikers zonder privacygevoeligheid komen op de verpleegafdeling dus weinig voor. 
llems:

$\%$ instemmende antwoorden

1. we zonder slot is gebrek aan privacy

2. aarwezigheid van luchtver risser is belangrik

Eveneens verschillende vragen werden gesteld met betrekking tot materieel-technische aspecten van po dan wel van de wc (zie Bijlage 6.1). Exploratief werd met behulp van factoranalyse nagegaan of de items te groeperen waren tot enkele dimensies. Dit bleek niet het geval, noch woor de materieel-technische aspecten van het po-gebruik noch voor die wan het wc-gebruik.

\subsection{Onderzoeksresultaten}

Op de afhankelijke variabele alsook op de variabelen die in eerste instantie als onafhankelijke variabelen bij dit onderzoek betrokken waren, werd geantwoord zoals weergegeven in Tabel 6.8 - waarbij voor een overzicht van de scores op de cluster sociaal-demografische variabelen zij verwezen naar Tabel 6.1.

Met deze gegevens als uitgangspunt wordt cen aanzet gegeven tot het beantwoorden van de onderzoeksvragen.

6.5.1 In welke mate, aldus de eerste onderzoeksvraag, zijn patiënten in een algemeen ziekenhuis bezorgd omtrent de stoelgang?

Tabel 6.2 laat zien dat het aantal (en percentage) bezorgden 65 (c.q. $41 \%$ ) bedraagt. De bezorgdheid geldt vooral het optreden van obstipatie (29 respondenten) en de veranderde frequentie van de stoelgang ( 20 respondenten). Zeven deelnemers specifi. ceren niet nader; vijf geven uiteenlopende redenen tot bezorgdheid. Het optreden van diarree en gevoelens van schaamte worden tenslotte genoemd door twee respondenten.

Voor de 52 participanten die melden in het ziekenhuis bezorgder te zijn dan thuis, is een duidelijk verband zichtbaar met de verminderde frequentie van de stoelgang: $X^{2}=18.69,2 d i f, p=0.001$.

6.5.2 De wolgende onderzoeksvragen betroffen nadere specificatie van factoren gerelateerd anan de bezorgdheid, waaronder eventueel wijzigingen die na ziekenhuisopname mogelijkerwijs optreden in iemands ontlastingspatroon. Welke veranderingen treden op in iemands defecatiepatroon na opname in een ziekenhuis?

Het ontlastingspatroon verandert bij drie op de vijf patiènten; bijna de helft van de participanten heeft verminderde frequentie of obstipatie.

Klachten over obstipatie melden vooral patiënten van de interne afdelingen, terwijl men op de chirurgische afdelingen meer bezorgd is over de gewijzigde frequentie van de ontlasting $\left(X^{2}=13.9,4 \mathrm{df}, \mathrm{p}<0.01\right)$.

Voor het overige verandert er nog meer aan spijsvertering en uitscheiding. De samenstelling van de maaltijden is anders dan thuis $(75 \%)$. Lichaamsbeweging, voor 
Afhanketike variabele:

instemmende

antwoonden

Bezorgdheid omtrent de stoelgang

$65(410)$

Onafhankelike variabelen:

Sociaal-demografische variabelen
1. Leetifid:
2. Geslacht:
3. Aard van hel specialsme van de afdeling
$<40$ jaar
$51(41 \%)$
wrowwen
$80(50 \%)$
intern
4. Type zilekenhuis:
academisch
$78(49 \%)$
5. Voor eerste maal in het ziekenhuis
$115(72 \%)$
$64(40 \%)$
$75(47 \%)$

Gedrags- en belevingsvariabelen thuls.

7. Lichamelik ongemak, ic last van ambeien

8. Gebruk laxerende middelen

9. Lichaamsbeweging belangrik woor detecatie

10. Gemecht an wo-rituelen

Gedrags- en belevingsvariabelen in ziekenhuis

11. Verander detecatiepatroon

12. Grote betrokkenheid op ontlastingsproces en -produkten ${ }^{\prime}$

13 . Schaamte t.o.v. stoelgangaspecten ${ }^{1,2}$

14. Contact-privacy 1 ?

15. Prwacygevoeligheid van po-gebrukersi, 2

\section{Zorgvariabelen}

16. Materieal-technisch, i.c. onstabiel op po 2

17. Materieet-hygiënisch, i.c. geen gelegentheid voor handen wassen? ${ }^{2}$

$35(47 \%)$

18. Prwacy-beschermende voorwarden, i. c. onvoldoende luchtverversing?

1. Deze schalen werden samengesteld door de standaardscores van de items te sommeren; het gemiddelde van deze schalen is dientengevolge ongeveer nul.

2. Aleen gevraagd aan, dus berekend over het aantal po-gebruikers, $n=75$

velen (nl. $54 \%$ van de respondenten, $X=8.67,3 \mathrm{df}, p=0.03$ ) een belangrijk stimulerend middel voor de ontlasting, is over het algemeen minder dan men thuis gewend was, namelijk bij $86 \%$ van de ziekenhuispatiënten. Voor $57 \%$ van de respondenten die melding maakten van vaste po-rondes - een vast moment tijdens de dag, bijvoorbeeld vóór de bezoekuren, watarop de patiènt de ondersteek of het gebruik van het toilet wordt aangeboden -, komt her tijdstip wan deze po- of toilet-ronden niet overeen met het moment van de stoelgang thuis. Ook is het in het ziekenhuis zelden mogelijk toilet-rituelen, gewoonten en gebruiken rondom de stoelgang (waarvan $47 \%$ van de patiënten zegt ze er thuis op na te houden) te handhaven.

In hoeverre dragen sommige van deze veranderingem, en eventueel andere factoren, bij tot problemen met of bezorgdheid ontrent de stoelgang in het ziekenhuis? 
6.5.3 Bezorgdheid bleek in onze onderzoekspopulatie te correleren met variabelen zoals aangegeven in Tabel 6.9 .

Bexorgdhetd omtrent de stoelgang blijkt sterk gerelateerd aan gedrags- en belevingsvariabelen in het ziekenhuis, namelijk aan de verminderde frequentie van de ontlasting, atan een verhevigde mate van betrokkenheid bij ontlastingsproces en -produkten, aan schatamte met betrekking tot de defecate, en tenslotte aan vermeerderde behoefte aan privacy in contact met anderen.

Deze laatste twee variabelen gelden overigens alleen voor de po-gebruikers. Eveneens relevant voor deze categorie van patiènten blijken enkele zorgvariabelen, namelijk het slagen van enkele verpleegkundige maatregelen als een stabiele zit op de beddepan en frisse lucht op de zaal.

Tabel 6.9 Samenhang tussen 'bezorgdheid' en enkele onafhankelijke variabelen (met behulp van Pearsons correlatiecoéfficiënten)

\begin{tabular}{|c|c|c|c|}
\hline Variabelen & po-gebruik & wc-gebruik & Totaal \\
\hline $\begin{array}{l}\text { Sociaaludemografische variabelen } \\
\text { leetijd } \\
\text { po-gebruik }\end{array}$ & $\begin{array}{l}.14 \\
\text { nvt }\end{array}$ & $\begin{array}{l}.07 \\
\text { nwt }\end{array}$ & $\begin{array}{l}13^{*} \\
.14^{*}\end{array}$ \\
\hline $\begin{array}{l}\text { Gedrags en belevingswariabelen thuis } \\
\text { laxerende middelen thuis }\end{array}$ & .13 & $30^{* *}$ & $20^{* *}$ \\
\hline $\begin{array}{l}\text { Gedrags- en belevingsvariabelen in ztekenhuis } \\
\text { frequentie stoelgang } \\
\text { batrokken op ontiastingsproces en -produkten } \\
\text { schaamte i.vm. defecatie } \\
\text { privacygevoeligheid in contact }\end{array}$ & $\begin{array}{l}-24^{*} \\
49^{* * *} \\
33^{* *} \\
.21^{*}\end{array}$ & $\begin{array}{l}-.36^{* *} \\
31^{* *} \\
\text { nut } \\
\text { nvt. }\end{array}$ & $\begin{array}{l}-.33^{* * * *} \\
.43^{* * * *} \\
.26^{*} \\
19^{*}\end{array}$ \\
\hline $\begin{array}{l}\text { Zorgvariabelen } \\
\text { stabiele "zit' op po } \\
\text { voldoende frisse lucht. }\end{array}$ & $\begin{array}{l}-43^{\text {ik⿲丶丶 }} \\
-23^{\pi}\end{array}$ & $\begin{array}{l}\text { nvt } \\
n v t\end{array}$ & $\begin{array}{l}-43^{* * *} \\
-.28^{* *}\end{array}$ \\
\hline $\begin{array}{l}p<0.05 \\
p<0.01 \\
p<0.001\end{array}$ & & & \\
\hline
\end{tabular}

Relevant voor de groep der wc-gebruikers blijkt de mate waarin men thuis (al) zijn toevlucht zocht tot laxerende middelen. Het verband blifft significant, gemeten over de gehele populatie. Eveneens voor de hele onderzoeksgroep bezien, blijkt een (zwak) verband voor 'leeftijd' en voor "po-gebruik'.

Teneinde de sterkte van de betrokken verbanden te kumnen vaststellen, werd een discriminant-analyse uitgevoerd, met 'bezorgdheid omtrent de ontlasting' als afhankelijke variabele. De analyse werd uitgevoerd zowel ten anzien van de gehele populatie, alsook ten aanzien van beide subgroepen, namelijk de po-en de wc-gebruikers. De resultaten zijn opgenomen in Tabel 6.10. 
Tabel 6.10 Bètacoëfficiënten van discriminantfunctie met bezorgdheid" als afhankelijke variabele

\begin{tabular}{|c|c|c|c|}
\hline Variabelen & $\begin{array}{r}\text { Totale } \\
\text { populatie }\end{array}$ & $\begin{array}{l}\text { WC-ge- } \\
\text { bruikers }\end{array}$ & $\begin{array}{l}\text { Po-ge } \\
\text { bruikers }\end{array}$ \\
\hline 1. aandacht voor ontlastingsproces en produkten & 0.75 & 0.44 & 0.57 \\
\hline 2. po-gebruik & 0.69 & - & - \\
\hline 3. verminderde ontiastingsfrequentie & 0.43 & 0.49 & 0.52 \\
\hline 4. gebruikt thuis laxerende middelen & 0.33 & 0.74 & 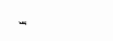 \\
\hline 5. op interne afdieling & 0.29 & 0.31 & - \\
\hline 6. schaamte m. b.t. defecatie & & & 0.80 \\
\hline 7. onstabiel op po & & & 0.58 \\
\hline 8. eerste ziekenhuisopname & & & 0.51 \\
\hline 9. te weinig frisse lucht & & & 0.42 \\
\hline 10. contact-privacy & & & 0.37 \\
\hline 11. gehecht aan wc-rituelen van thuis & & & 0.35 \\
\hline 12. geen gelegenheld handen te wassen & & & 0.22 \\
\hline Eigenvallue & 0.58 & 0.44 & 1.62 \\
\hline Canonical corr. & 0.61 & 0.55 & 0.79 \\
\hline Wilks" Lambda & 0.63 & 0.69 & 0.38 \\
\hline
\end{tabular}

Voor de totale populatie blijkt 'bezorgdheid omtrent de ontlasting' op de verpleegafdeling verklaard door enkele variabelen uit drie van de vier categorieën weergegeven in figuur 6.1. De betreffende problematiek blijkt gerelateerd aan de aard van de afdeling: op interne afdelingen wordt deze intensiever ervaren. Ook blijkt het gebruik van de po in bed een factor van invloed op de bezorgdheid. Voor wat de thuis-variabelen betreft: gerelateerd aan bezorgdheid omtrent de stoelgang in het ziekenthuis blijkt het thusgebruik van laxerende middelen. Van de ziekenhuisvariabelen blijken er twee gerelateerd aan bezorgdheid: de verminderde frequentie van de stoelgang, alsook de grote betrokkenheid, de fixatie op ontlastingsproces en -produkten.

De genoemde variabelen dragen bij aan de verklaring van de defecatiebezorgdheid van de hele onderzoeksgroep alsook, meer ingeperkt, van de patiënten die de wo gebruiken. Voor po-gebruikers blijkt schaamte een belangrijke factor var invloed, alsook de zorgvariabelen, waaronder vooral de instabiliteit van de beddepan.

Tussen bezotgdheid omtrent de ontlasting en de ziekenhuisvariabelen, met name de grote betrokkenheid op ontlastingsproces en -produkten, werd, hierboven in $\$ 6.2$, een wederzijdse correlatie verondersteld. Degene die bezorgd is, is gefixeerd op de ontlasting; degene die gefixeerd is, toont zich bezorgd. De relatie tussen bezorgdheid an de grote betrokkenheid op de stoelgang blijkt nu echter niet tautologisch: vooral bij de vrouwen blijkt spreiding van beide variabelen over deze subgroep $(p=0.27)$. On deze reden werd de betrokkenheid op de stoelgang in de discriminantwanalyse opgenomen. Bij weglaten van deze variabele uit de analyse, om reden van veronderstelde tautologische betrekking, koml de wariabele leeftijd naar voren als verklarende onaflhankelijke variabele, namelijk in de hele populatie alsook bij de po-en bij de wc-gebruikers: meer bezorgdheid komt voor bij oudere patiënten.

De variabele "gebruik van laxerende middelen thuis", die een verklarende variabele 
van "bezorgdheid omtrent de stoelgang" blijkt voor zowel de hele onderzoeksgroep alsook meer in het bijzonder bij de wc-gebruikers, zow een waardevolle indicator Kunnen ziju bij opnanie van patienten met "stoelgang-nisico" op de verpleegafdeling. Bij intake-gesprekken zou de vragg naar eventueel gebruk van laxerende middelen thuis a an ongeveer $40 \%$ van de patienten veel narigheid kunnen voorkomen.

De instabiliteit wan de houding op de ondersteek blijkt eveneens een inwloedrijke verklarende variabele. De patient stabiel op de po plaatsen, en ook anderszins de omstandigheden bevorderen waaronder de ontlasting zo voorspoedig mogelijk verloopt, behoort tot de competentie van verplegenden en verzorgenden. Het belang dat patienten blijkaar hechten aan deze kundig uitgevoerde ingreep, mag pleiten voor blijvende aandacht voor dit onderdeel in de beroepsopleidingen.

De relatief geringe mogelijkheid tot verklaring van de afhankelijke variabele is opmerkelijk, omdat door Wright significante verbanden waren gevonden tussen "worry and concern" en een aantal persoons- en omgevingskenmerken. Een poging tot verklaring hiervoor wordt ondernomen in paragraal 6.6 .

\subsection{Discussie en conclusies}

Het deelonderzoek waarover in dit hoofdstuk wordt gerapporteerd, was opgezet deels als replicatie deels als verbreding van een bestaand onderzoek (Wright, 1974). In zowel het Engelse als het Nederlandse onderzoek werd "bezorgdheid omtrent de stoelgang" geconstateerd, respectievelijk bij 27 en bij 41 procent. De belangrijkste aanwijsbare reden bleek obstipatie of minder frequente stoelgang. Maar klaarblijkelijk waren er ook andere factoren van invloed.

In bepaalde opzichten brachten beide onderzoeken verschillende resultaten. Een nadere beschouwing wan de belangrijkste werschillen kan nuttig zijn.

6.6.1 War tussen beide onderzoeken verschillen werden geconstateerd, kunnen deze tenminste gedeeltelijk worden toegeschreven aan de deelname van chirurgische patienten aan het replicatie-onderzoek.

Problemen omtrent de stoelgang kunnen zich verschillend voordoen voor interne en voor chirurgische patienten. Zo bleken patienten die deze problematiek op de verpleegafdeling ondervonden, vaak degenen die zich thuis al zorgen maakten omtrent de ontlasting. Welnu, de thuisbezorgden in dit deel-onderzoek bleken overwegend interne patienten $(\mathrm{p}<0.05)$. Deze gaven ook blijk van een verminderde frequentie van de stoelgang in het ziekenhuis ( $p<0.01$ ). Anderzijds bleek bij de chirurgische patienten cle bezorgdheid omtrent de stoelgang gerelateerd aan het gebruik van de ondersteek $(p<0.025)$, vooral wanneer het jonge patiënten betrof $(p<0.025)$.

Problemen met of bezorgdheid omtrent de stoelgang maken misschien deel wit van bepaalde gedragspatronen, eigen aan interne of chirurgische patiënten. Vervolgonderzoek zou nodig zijn on deze gedragspatronen, al dan niet gerelateerd aan defecatieproblematiek, nader in kaart te brengen. 
6.6.2 Een opmerkelijk verschil tussen dit onderzoek en dat van Wright bleek hei feit dat "bezorgdheid omtrent de stoelgang" in dit deelonderzoek amper nauwkeuriger omschreven kon worden, terwijl Wrights onderzoek rijk aan significante verbanden leek. De reden voor dit verschil is waarschijnlijk grotendeels gelegen in de wijze van dataverwerking. Wright beperkte zich tot chi-kwadraattoetsen - waarvan zij er een groot aantal uitvoerde ( 29 van de 35 tabellen in haar onderzoeksverslag geven $X^{2}$-toetsen weer, de overige zes tonen frequentieverdelingen). Ruth M. Barnard, Wrights recensent in Nursing Research (1976), wijst op de beperkingen van deze werkwijze. De robuustheid van relaties was niet aangegeven; bij meer adequate statistische bewerking bleek die gering of afwezig.

Interne structuren tussen variabelen onderling, zoals in dit deelonderzoek aangebracht, laten dus een ander beeld zien van de bestudeerde problematiek dan bij Wright, ook al zal het probleemgebied in beide gevallen identiek zijn geweest. 


\section{Betrouwbaarheid van patiënteninformatie na ziekenhuisopname; methodologische reflecties}

\subsection{Beperkingen van zelfrapportage van patiënten}

Door degenen die de methodiek en de systematiek van het verplegen bestuderen, wordt algemeen aangenomen dat de verpleegkundige interventie moet berusten op een beoordeling van de situatie waarin de zorgvrager zich bevindt, hetzij diens situatie in zijn totaliteit hetzij met betrekking tot beperkte, nauwkeurig af te bakenen patiëntproblemen (Little \& Carnevali 1969, Marriner 1975, Yura \& Walsh $1978^{3}$ ). Het behoort tot een lange traditie in de ziekenverpleging, de zorgverlening te oriènteren op leefomstandigheden die door de patiënt als gebruikelijk worden ervaren, en situaties te creëren die de patiënt als vertrouwd wóórkomen (Hunt \& Marks-Maran, 1980). Voor de stoelgang van patiënten in het ziekenhuis impliceert dit het maximaal bevorderen van voortzetting van het 'normale' defecatiepatroon, bijvoorbeeld met behulp van stoelgang-regulerende diëten, waar nodig verstrekken van laxerende of stoppende middelen, bevordering van lichaamsbeweging, het stimuleren althans het dulden van wc-gewoonten als roken en lezen op de wc, het stimuleren althans dulden van defecatie op de voorkeursmomenten van de patiënten in plaats van op momenten die de verpleging het meest geschikt vindt, enzovoort.

Wanneer zich, hetzij bij opname van een patiënt op de verpleegafdeling, hetzij in de loop van diens ziekenhuisverblijf zorgproblemen yoordoen, moet de verpleegkundige dus beschikken over kennis omtrent de normale (gezondheids)toestand van de patiënt, de situatie namelijk in relatie waarmee afwijkende, zorgelijke en problematische toestanden beoordeeld kunnen worden. Voor de verpleegkundige rijst dan de vraag of, en in welke mate, de informatie door de patiënt verstrekt over diens ervaren gezondheid thuis, i.c. diens normale ontlastingspatroon, juist en betrouwbaar is.

Het is inderdaad de vraag of verpleegkundigen, indien nodig, kunnen beschikken over de informatie die relevant wordt geacht voor de verpleegkundige anamnese, diagnose en interventie. De vraag, bijvoorbeeld, 'How trust worthy are bowel histories?" werd door Manning, Wyman \& Heaton (1976) genuanceerd beantwoord na vergelijking tussen mondelinge gegevens van patiënten en door then bijgehouden dagboeken. In interviews bleken over het algemeen patiënten met een geringe frequentie wan de stoelgang deze (nog) lager te beoordelen, terwijl patiënten met een hoge frequentie deze (nog) hoger veronderstelden. Ook op andere punten bleken aanmerkelijke verschillen tussen de geregistreerde feitelijkheid en de perceptie ervan door de patiênten zelf, bijvoorbeeld het aantal dagen zonder ontlasting, het aantal malen ontlasting tussen twee 
maalijden, en het juiste moment van de stoelgang 's morgens (veel mensen blijken meer dan zijzelf vermoeden vór het ontbijt naar helt toilet te gaan).

Vertekening van informatie omtrent het defecatiepatroon in het bijzonder en de thuis ervaren gezondheid in het algemeen, door de patiënt na ziekenhuisopname, lijkt verklaarbaar vanuit verschillende optiek.

Ziek-zijn kan op zichzelf bij patiënten tot allerlei emotionele reacties leiden. Ziekenhuisopname, bekend als een ingrijpende gebeurtenis in iemands bestaan (Poslavsky 1956, Ellerbeck 1961 , Bremer $1972^{2}$ ), versterkt de genoemde gevoelsreacties ten gevolge van de ziekte; veelvuldig wordt gewezen op angst., afhankelijkheid, onzekerheid, verdriet en machteloosheid (Visser, 1984). Het optreden en de hevigheid van deze emoties zijn uiteraard gerelateerd aan persoonskenmerken (bijvoorbeeld stressbestendigheid) en situationele kenmerken (bijwoorbeeld de ernst van ziekte of aandoening, of ook de roldiscontinuïteit voor de opgenomen patiënt, Kleber \& Brom, 1983). Opname en verbligf in het ziekenhuis kan een dermate emotioneel beladen gebeurtenis zijn, dat infomalie door patienten verstrekt over aspecten van gezondheidsbeleving thuis, i.c. over de stoelgang, op enigerlei wijze "gekleurd'zou zijjn.

Maar een ziekenhuisopname is eveneens een situatie mel de kenmerken van een "bureaucratic format', waarin 'the person tends to conduct himself during the encounter so as to maintain both his own face and the face of the other participants' (Strong, 1988). Opname op de verpleegafdeling inclusief verpleegkundige anamnese is zoals het medisch consult, een gebeurtenis waarbij het uiterst beleefd toegaat: patiënt en verpleegkundige respecteren de aan elkaar toegeschreven identiteit en status. De verpleegkundige is belangstellend, maar tevens afstandelijk, 'deskundig' en geinteresseerd in gerichte informatie; de patiënt is gauw genegen zich tot die specifieke informatie te beperken. De gesprekspartners volstaan in deze situatie, door Goffman gekarakteriseerd als 'facework' (1967), met het ophouden van de schone schijn ('maintenance of a smooth surface appearance', Strong, 1979), het bewaken van het ideale imago. Ook bezien als 'facework' kan ziekenhuisopname een situatie zijn waarin niet die informatie wordt verkregen die nodig is voor adequaat verpleegkundig handelen.

Vervolgens kan vertekening van patiëntinformatie eveneens worden begrepen vanuit de 'cognitive dissonance theory', waarin wordt gesteld dat in bepaalde gevallen dissonantie tussen (twee) cognitieve elementen kan optreden, namelijk in geval 'het tegendeel van het ene element volgt uit het andere' (Festinger, 1957). Het niveau van dissonantie stijgt naarmate deze cognitieve elementen belangrijker zijn voor het indiviclu. Opname in een ziekenhuis kan dan worden beschouwd als een situatie waarin $z i c h$, onder invloed van de gebeurtenissen, percepties van de eigen cognitieve elemenren kunnen wijzigen. De situatie thuis kan men, bij opname op de verpleegafdeling, anders, namelijk idealiserend mat ook well in negatieve zin, percipiëren.

Vertekening van patièntinformatie kan tenslotte het gevolg zijn van het tijdsverloop waa rover een en ander platatsvindt. Met de tijd verandert ook de mens en zijn lee fwereld, Bij retrospectieve navraag naar elementen van iemands gezondheidssituatie kan, vooral wanneer de bedoelde situatie niet in een recent verleden ligt, vervaging optreden van het herinnerde. De vervaging kan plaatsvinden wanneer aan de gezondheidssituatie inmiddels niets verandert, maar vooral indien de situatie zich wijzigt wat gedurende de laatste weken vóor ziekenhuisopname al gauw het geval kan zijn. Deze bias vormit 
een extra dimensie, methodologisch van aard want de stabiliteit betreffende, van het betrouwbaarheidsprobleen van patientinfomatie.

Ondat hoe dan ook voor de verpleging bij opname wan de patient infommtie omment diens defecaciepatroon thuis van belang is, werd de volgende onderzoeksvraag geformuleerd:

Verandert, en zo ja in welk opzich en in welke mate, her zelfoondeel van patienten wa ziekenhwisopname betreffende de thuis ervaren gezondheid in het algeneen en berneffende de stoelgang in het bijonder?

\subsection{Opzet en verloop van het onderzoek}

Om een antwoord te verkrijgen op bovengeformuleerde vraag, werd een onderzoeksgroep, bestaande uit (toekomstige) patiënten, zowel wór als tijdens de ziekenhuisopname geënquêteerd. Thuis en in het ziekenhuis werden identieke vragen gesteid over de thuis ervaren gezondheid, alsook over de stoelgang in de normale thuisomstandigheden.

7.2.1 De onderzoekspopulatie kwam tot stand met behulp van bestaande wachtlijsten van een middelgroot ziekenhuis. Uitgebreide wachtijisten bleken slechts beschikbaar voor de afdeling orthopedie, zodat het deelonderzoek zich bepenkte tot orthopedische patiënten. Selectie van potentiële deelnemers kwam tot stand aan de hand van de criteria gehanteerd in het deelonderzoek waarover hierboven in hoofdstuk 6 werd gerap porteerd; deze respondenten participeerden in feite eveneens in het replicatieonderzoek.

Aan de hand van de genoemde criteria werden van de wachtlijsten 110 potentiële deelnemers geselecteerd. Van deze werden er slechts 41 thuis benaderd. Sommige potentièle deelnemers waren juist vóór onze contactname in het ziekenhuis opgenomen. $\mathrm{Bij}$ andere werd afgezien van ziekenhuisopname en operatie. Sommige potentiële respondenten hadden besloten vóor opname in het ziekenhuis nog enige tijd met vakantie te gaan. Anderen, die nog volop in het arbeidsproces geinvolveerd waren, hadden geen trijd of waren niet gemotiveerd om aan het onderzoek deel te nemen.

Van de 41 thuis benaderde participanten werden er in het ziekenhuis slechts 21 opnieuw geẻnquêteerd. Van de 20 resterenden weigerde weliswar niemand verderê medewerking; zij werden echter niet in het verdere onderzoek opgenomen om administratieve redenen, voornamelijk omdat zij korter dan vijf dagen op de verpleegafdeling verbleven. Deze 20 resterenden verschilden niet significant van de dubbelgeẻnquêteerden wat leeftijd, geslacht en recente eerdere ziekenhuisopname betreft.

De enquête in het ziekenhuis vond plaats gemiddeld 28 dagen na het huisbezock, varièrend wan 8 tot 52 dagen. De groep was, wat de opname-indicatie betreft, samengesteld zoals weergegeven in Tabel 7.1.

De groep van deelnemers, in meerderheid woonachtig in dezelfde middelgrote gemeente, was heterogeen van samenstelling wat de maatschappelijke positie betreft: scholieren, huiswrouwen, werkenden en éen WAO-er. Onder de 21 participanten waren 
$1: 5$ vrouwen. De leeftijden varieerden van 17 tot 57 jaar. Homogeen samengesteld was de groep naar zorgbehoefte: de patiënten met de in Tabel 7.1 genoemde opnameindicaties kwamen allen als lopend 'patiënt' het ziekenhuis binnen, zij kwamen als 'patiënt" met elkaar overeen in mobiliteit, behoefte aan ondersteuning bij de ADL-functies en afwezigheid van ziektegevoel.

Tabel 7.1 Opname-indicatie van de dubbel-geënquêteerde patiënten

\begin{tabular}{lccr}
\hline Opname-indicatie & mannen & vrouwen & Totaal \\
\hline schouderoperatie & 1 & 2 & 3 \\
meniscus & 3 & 4 & 7 \\
teen-/votoperatie & 1 & 1 & 9 \\
anders & 1 & 15 & 21 \\
\hline Totaal & 6 & & 2 \\
\hline
\end{tabular}

7.2.2 De thuis ervaren gezondheid werd gemeten met behulp van de Vragenlijst Onderzoek Ervaren Gezondheid, de VOEGlijst (Dirken, 1967), die 47 klachten bevat. Deze versie van de VOEG blijkt op grond van factoranalyse en face-validity, en na correctie voor de algemene klaaggeneigdheid, uiteen te vallen in 13 onderdelen: 9 subschalen en 4 afzonderlijke items (Joosten \& Drop, 1987). Van de subschalen lijken er twee relevant in het kader van onderzoek naar de stoelgangproblematiek: één heeft betrekking op de spijsvertering (maag-/buikklachten: 4 items) en één op het postuur (men voelt zich te dik dan wel te mager: 2 items).

Van een vragenlijst als de VOEG mag worden verwacht dat deze een grote mate van intrasubjectieve consistentie bezit. Als iemand op $t_{1}$ rapporteert geregeld last van hoesten te hebben, kan worden verwacht dat hij op $t_{2}$, wanneer dit miet te ver van $t_{1}$ afligt, retrospectief met betrekking tot $t_{1}$ hetzelfde beweert. Verondersteld kan dus worden dat de antwoorden in het ziekenhuis gegeven op de vragen van de VOEG-lijst over thuis (= A2) weinig verschillen van de antwoorden thuis gegeven (= A1). Bij veronderstelde intrasubjectieve stabiliteit van de VOEG-scores, duiden wijzigingen in de antwoorden A2 dus op feitelijk gewijzigde perceptie van de gezondheid thuis (cf. Fig. 7.1).

7.2.3 De perceptie van het eigen defecatiepatroon werd gemeten met behulp van een lijst met voorgestructureerde vragen betreffende de stoelgang, relevant voor een verpleegkundige anamnese (Tabel 7.2).

De vragen werden thuis gesteld tijdens een vraaggesprek waarbij ook onderwerpen aan de orde kwamen als eet- en drinkgewoonten, dieet, bewegingspatroon, medicatie, toilethygiëne, enzovoort. Na tenminste 5 dagen verblijf in het ziekenhuis werden de zeven geselecteerde vragen opnieuw gesteld, weer binnen het kader van een uitgebreider vraaggesprek, en werd de VOEG-lijst opnieuw afgenomen, desgevraagd na korte uiteenzetting van de bedoeling van deze dubbele enquêtering. 
1. Normale frequentie wan de ontlasting thuis

2. Normale hoeveelheid geproduceerde ontlasting thuis

3. Heeft men voorkeursmoment voor de stoelgang thuis

4. Zo ja, wanneer

5. Heeft men toiletgewoonten thuis

6. Zo ja, welke

7. Hoe belangrijk G.q. noodzakellk zilin die voor een 'normale' stoelgang

Omtrent de intrasubjectieve stabiliteit van de antwoorden op deze vragen op twee verschillende momenten zijn ons uit de literatuur geen gegevens bekend. Ook hier is werondersteld dat de respondent zich op $t_{2}$ herinnert of deze op $t_{1}$ bijwoorbeeld een vast moment voor de stoelgang had. Naar analogie van de VOEG-lijst hoeven de antwoorden, retrospectief in het ziekenhuis gegeven, omtrent de stoelgang thuis (= B2) niet aanmerkelijk te verschillen van de antwoorden op dezelfde vragen thuis gesteld (= B1). Bij veronderstelde intrasubjectieve stabiliteit in het antwoordenpatroon betreffende de stoelgang, duiden wijzigingen in de antwoorden $B 2$ dus op feitelijk gewijzigde perceptie van de stoelgang thuis:

Thuis:

Beoordeling eigen gezondheid a.d.h.v. VOEG:

Antwoorden: A1

Beoordeling eigen defecatiepatroon a.d.h.v. enquête

Antwoorden: B1
Na ziekenthuisopname:

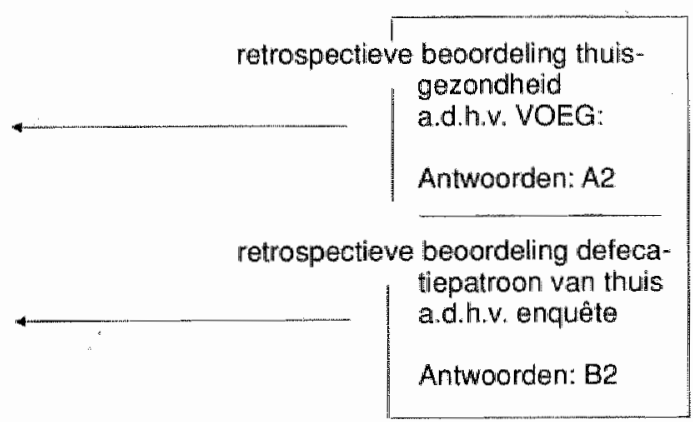

Fig. 7.1 Meting op twee momenten van eigen oordeel betreffende de gezondheid en defecatiepatroon zoals thuis ervaren

$\mathrm{Bij}$ deze onderzoeksopzet wordt dus uitgegaan van een analogie tussen de $\mathrm{A}$ en de $\mathrm{B}$ antwoorden. Indien de A antwoorden stabiliteit vertonen en dan met name die vragen uit de VOEG die betrekking hebben op kJachten betreffende de spijsvertering, dan wordt aangenomen dat ook de B antwoorden stabiliteit bezitten. De stabiliteit van de A antwoorden, de desbetreffende antwoorden op de VOEG-lijst, moet dus eerst worden aangetoond. 


\subsection{Resultaten met betrekking tot de VOEG-lijst}

Tabel 7.3 geeft een overzicht van de totaalscores op de VOEG van de 21 proefpersonen. De theoretische minimum- en maximum-scores bedragen respectievelijk 0 en 47. De gemiddelde scores bedragen vóor opname 14.9, ema 13.1; het verschil is significant ( $\mathrm{p}$ $=0.01)$.

Tabel 7.3 VOEG-scores op twee tijdstippen $(n=21)$

\begin{tabular}{|c|c|c|c|}
\hline & $\begin{array}{l}\text { Vooir } \\
\text { opname }\end{array}$ & $\begin{array}{l}\mathrm{Na} \\
\text { opname }\end{array}$ & $\begin{array}{l}\text { Aantal gelijke } \\
\text { kachten op beide } \\
\text { tijdstippen }\end{array}$ \\
\hline & 4 & 4 & 2 \\
\hline & 5 & 5 & 2 \\
\hline & 7 & 5 & 3 \\
\hline & 8 & 5 & 4 \\
\hline & 6 & 6 & 5 \\
\hline & 7 & 5 & 5 \\
\hline & 13 & 10 & 6 \\
\hline & 7 & 8 & 7 \\
\hline & 8 & 9 & 7 \\
\hline & 15 & 8 & 8 \\
\hline & 15 & 9 & 8 \\
\hline & 14 & 12 & 9 \\
\hline & 21 & 10 & 9 \\
\hline & 12 & 17 & 10 \\
\hline & 17 & 18 & 15 \\
\hline & 24 & 17 & 16 \\
\hline & 24 & 22 & 20 \\
\hline & 23 & 24 & 22 \\
\hline & 23 & 28 & 22 \\
\hline & 28 & 24 & 22 \\
\hline & 31 & 30 & 28 \\
\hline Totaal gemiddelde: & 14.9 & 13.1 & 11.0 \\
\hline Standaarddeviatie: & 8.0 & 8.1 & 7.6 \\
\hline
\end{tabular}

De tabel laat zien dat er grote overeenstemming bestaat tussen de scores op beide tijdstippen ( $r=0.89$ ); er is dus sprake van een grote betrouwbaarheid. Toch zijn er enkele kanttekeningen te maken waataan de twee volgende subparagrafen zijn gewijd.

7.3.1 Allereerst valt op dat geen enkele proefpersoon op beide tijdstippen precies dezelfcte antwoorden geeft. Is er een patroon herkenbaar in de afwijkingen?

In totaal zijn 987 antwoorden, namelijk op 47 vragen van 21 respondenten op twee tijdstippen, gegeven. Van elk antwoord kan op de twee tijdstippen worden vastgesteld of er wel dan niet een klacht is geuit, en of de twee antwoorden overeenkomen. 
Na opname in het ziekenhuis

\begin{tabular}{lrrr} 
Vón opname & Klacht & Geen klacht & Totaal \\
Klacht & $230(23 \%)$ & $82(8 \%)$ & 372 \\
Geen klacht & $46(5 \%)$ & $629(64 \%)$ & 675 \\
\hline Totaal & 276 & 711 & 987 \\
\hline
\end{tabular}

In totaal blijkt $87 \%$ van de antwoorden na opname gelijk aan die van vóór de opname $(23 \%$ klachten $+64 \%$ geen klachten). Deze overeenstemming in de antwoorden is een goede maatstaf om aan te geven dat de overeenstemming hoog of laag is. Immers, ook op grond van toeval kan er overeenstemming zijn; in deze tabel is dat $58 \%$. Er bestakn overeenstemmingscoëfficiënten die rekening houden met deze toevalsovereenkomst, bijvoorbeeld Cohens kappa. Gekozen is voor die variant van kappa die bovendien nog rekening houdt met verschillen in randtotalen. Deze coefficiënt word hier $\mathrm{C}$ genoend.

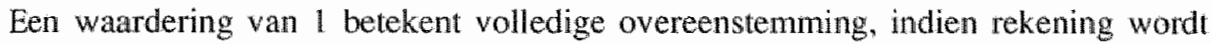
gehouden met de toevalsovereenstemming en versehillende randtotalen. 0 betekent de afwezigheid van owereenstemming. Scores beduidend lager dan 0 wijzen op systematische tegenspraak tussen uitspraken. In Tabel 7.4 bedraagt de C 0.76 , een hoge waarde maar geen weergave van een volmaakte overeenstemming.

Wat kunnen bronnen zijn van deze divergentie? Een mogelijke bron kan gelegen zijn in verschillen tussen individuen: het antwoordpatroon van de ene respondent kan stabieler zijn dan van de andere. Dit blijkt inderdaad het geval. De overeenstemming uitgedrukt in $\mathrm{C}$ loopt voor de 21 respondenten uiteen van 0.33 tot en met 1.00 ; de mediaan bedraagt 0.79 . Er bestaan dus individueel belangrijke verschillen. De hoogte van de $\mathrm{C}$ blijkt samen te hangen met de hoogte van de VOEG-scores. Mensen met een hoge VOEG-score blijken een stabieler antwoordpatroon te hebben dan respondenten met een lage VOEG-score (Tabel 7.5).

Tabel 7.5 Overeenstemming in VOEG-scores naar de hoogte van de scores, berekend over alle antwoorden

VOEG-score

Laagste zeven

$(n=329)$

Middelste zewen

$(n=329)$

Hoogste zeven

$(n=329)$

\section{C}

0.62

0.71

0.78 
Blijkbaar neigen personen met een laag klachtenniveau tot het geven van instabiele antwoorden.

Eein onvolledige overeenkomst in antwoordpatroon kan ook als oorzak hebben dat sommige vragen stabielere antwoorden oproepen dan andere. Ook dit blijkt hel geval. De laagste kappa bedraagt -0.08 , de hoogste 1,00 ; de mediaan ligt bij 0,70 . Deze verschillen zijn spectaculairder dan bij de interindividuele variatie.

Op het niveau wan de afzonderlijke items blijkt tussen sommige items meer, tussen andere minder overeenstemming in antwoorden op de beide meetmonenten. Betrekkelijk hoog in overeenstemming scoren items betreffende kortademigheid, het postuur (te mager, te dik), slapeloosheid, maag- en buikklachten, zich fit of flink voelen, hoofdpijn. Betrekkelik laag in overeenstemming scoren relatief vage klachten waartussen op twee verschillende meetmomenten gemakkelijk fluctuatie ontstaat, zoals jeuk, prikkelende ogen, vieze smaak in de mond.

De relatief hoge overeenstemming tussen items die in werband gezien kunnen worden met de ontlasting mag ter ondersteuning worden opgevat van de verwachting dat omtrent de stoelgang zelf in de tijd betrekkelijk stabiel zou worden geantwoord.

7.3.2 Behalve de verschillen in beantwoording op de twee meetmomenten, valt eveneens op dat het gemiddelde aantal klachten over de thuis ervaren gezondheid na ziekenhuisopname kleiner is dan daarvoor. Ook dit resultaat is op het eerste gezicht niet evident.

Het totale aantal klachten over de thuis ervaren gezondheid is in het ziekenhuis significant kleiner dan het aantal klachten in de thuissituatie zelf gemeld. Over het algemeen zegt men in het ziekenhuis dat men thuis fitter en minder moe was dan dat men dit in de thuissituatie zelf inschatte. Men beoordeelde zich, retrospectief, thuis fitter, minder slapeloos, minder moe, niet zo slaperig, genietend van een betere eetlust. Retrospectief had men thuis minder last van pijnlijke voeten dan toen daar, thuis, naar gevraagd werd. Fitheid thuis wordt, retrospectief, nogal positief ingeschat.

Kortom: hoe cok berekend, de stabiliteit van de VOEG-lijst blijkt in het hier bestudeerde geval van 21 dubbel-geënquêteerde proefpersonen redelijk hoog (de "ruwe" overeenstemming bedraagt $0,89 \%, C=0,76$ ). De divergentie tussen de antwoorderi op beide meetmomenten bleek enerzijjs gerelateerd an instabiel antwoordgedrag op individueel niweau (vooral personen met weinig gezondheidsklachten bleken dit te vertonen). Anderzijds blijken sommige vragen zich meer dan andere te lenen voor stabiele beantwoording. Gezondheidsklachten die in meer of mindere mate aan de stoelgang gerelateerd kunnen worden (maag-en buikklachten, alsook klachten over het posturr), blijken tot stabiele beantwoording aanleiding te geven. De VOEG als geheel mag als (redelijk/goed) stabiel worden beschouwd: antwoordverschuiving betreft slechts een beperkt gedeelte van de hele schaal.

\subsection{Resultaten ten aanzien van het defecatiepatroon}

Mei betrekking tot het defecatiepatroon werden de respondenten zeven vragen gesteld (cf. Tabel 7.2); daarvan konden er drie beantwoord worden indien daaraan vooraf 
gestelde vragen bevestigend waren beantwoord. De vier vragen die door alle respondenten beantwoord konden worden, werden door 11 van de 21 participanten op 12 beantwoord zoals op 1 . Deze groep van 11 verschilt van de groep respondenten met retrospectief gewijzigde antwoorden niet opmerkelijk in leeftijd, geslacht en eerder recent ziekenhuisverblijf.

De 10 respondenten met retrospectief gewijzigde antwoorden scoorden zodanig dat de vier vragen onderling geen stabiel patroon in afwijkende antwoorden vertoonden.

Retrospectief blijkt men de frequentie van de stoelgang met aannemelijke betrouwbaarheid te rapporteren (cf. Tabel 7.7). Eveneens betrouwbaar wordt gerapporteerd over wc-gewoonten (lezen, puzzelen, enz.) Veel minder betrouwbaar tot onbetrouwbaar echter blijkt het oordeel over het eventuele vaste tijdstip voor de stoelgang, respectievelijk de hoeveelheid faeces per stoelgang (Tabel $7.8 \mathrm{t} / \mathrm{m} 7.10$ ).

Tabel 7.7 Consistentie in beantwoording Vraag 1:

Frequentie van de stoelgang

\begin{tabular}{lcccr}
\hline Thuis: & 3-6x per week & dagelijks & $1-3 \times$ per dag & Totaal \\
\hline In ziekenhuis: & 5 & 0 & 0 & 5 \\
3 6xper week & 0 & 11 & 2 & 13 \\
dagelijks & 0 & 0 & 2 & 2 \\
1-3xper dag & 5 & 11 & 4 & 20 \\
\hline Totaal & & & & \\
\hline
\end{tabular}

1 respondent antwoordde $2 x$ 'weet niet"

Overeenstemming: $90 \%$

C: 1,00

De overeenstemming, in Tabel 7.7 , tussen de antwoorden op beide meetmomenten is groot. In het ziekenhuis dachten zich 13 respondenten, twee mér dan thuis, een dagelijkse stoelgang toe en vertoonden daarmee wat dat betreft een antwoordiendens in cle richting van sociale normen.

Tabel 7.8 Consistentie in beantwoording Vraag 2: Hoeveelheid faeces per stoelgang

\begin{tabular}{lccc}
\hline Thuis: & ja & nee/beetje & Totaall \\
\hline In ziekentiuis: & & 0 & 15 \\
ja & 15 & 0 & 5 \\
nee/beeije & 5 & 0 & 20 \\
\hline Totaal & 20 & 0 \\
\hline
\end{tabular}

1 respondent antwoordde $2 \times$ 'weet niet'

Dvereenstemming: $80 \%$

C: 0.0 per definitie 
In Tabel 7.8, betreffende de hoeveeheid taeces per stoelgang, blijkt dat de overeenstemming, intrasubjectief, russen de antwoorden op beide meetmomenten gering is. Een kwart van de respondenten beantwoord deze vragg in het ziekenhuis weinig of niet consistent.

Van de 20 respondenten die informatie verstrekten over een eventueel vast tijdstio woor de stoelgang thuis, bevestigden 16 dit zowell thuis als in het ziekenhuis (Tabe1 7.9).

Tabel 7.9 Consistentie in beantwoording Vraag 3: Vast tjjostip per dag voor de stoelganig

\begin{tabular}{lccr}
\hline Thuis: & a & nee & Totaal \\
In ziekentuis: & 16 & & \\
ja: & 1 & 1 & 18 \\
nee & 17 & 3 & 2 \\
\hline Totaal & 17 & 1 & 20 \\
\hline
\end{tabular}

1 respondent anlwoordde $2 x$ 'weet miet"

Overeenstemming: $85 \%$

C. 0.41

Deze 16 vermeldden in het ziekenhuis retrospectief 18 waste momenten, waarvan 4 maal vóor en $8 \mathrm{maal}$ ná het ontbijt. Deze 18 antwoorden waren alle ook thuis gegeven. Daar echter waren door de 16 geënquêteerden meer antwoorden dan in het ziekenhuis gegeven (waaronder 3 maal vór het ontbijt en 3 maal gedurende de dag).

Omtrent gewoonten tijdens de defecatie was door 8 personen op beide meetmomenten bevestigend geantwoord (tabel 7.10)

Tabel 7.10 Consistentie in beantwoording Vraag 4: Gewoonten tijdens de stoelgang

\begin{tabular}{lcrr}
\hline Thuis: & ja & nee & Tataal \\
\hline In ziekenhuis: & 8 & 1 & 9 \\
ja & 1 & 11 & 12 \\
noe & 9 & 12 & 21 \\
\hline Toltaal & & &
\end{tabular}

Overeenstemming: 90\%

C: 0.81

Thuis noemden deze 8 respondenten 11 gewoonten: 6 maal lecturr, 4 maal roken en I mal puzzelen. Rerrospectief werden deze zelfde gewoonten genoemd. In het ziekenhuis echter werden door de geënquêteerden meer antwoorden gegeven dan thuis, namelijk nog 2 maal lectuur, 1 maal radio belluisteren en 1 maal koffie. Over het belang dat men hecht aan deze wc-gewoonten - belangrijk voor 4 , noodzakelijk voor 1 respondent - is men vrij eenstemmig: de overeenstemming bedraagt $75 \%, \mathrm{C}$ is 1,00 .

Informatie door patienten in het ziekenhuis gegeven omtrent de stoelgang thuis, blijkt 
dus op sommige punten voldoende betrouwbaar (frequentie van de stoelgang, we-ge woonten), op andere punten weinig (eventueel vast moment) of het betrouwbar (hoeveelheid faeces). Omtrent de precieze tijd van het vaste monent, alsook ontrent de aard van de wc-gewoonten wordt consistent geantwoond. Men is evenwel thais uitwoeriger aangaande de vaste momenten, in het ziekenhuis daarentegen ontrent de aard van de wc-gewoonten. Deze wisselende betrouwbaarheid of verschuivende uitvoerigheid lijkt, althans bij eerste benadering, willekeurig en moeilijk verklaarbaar.

Is er nu enige overeenkomst merkbaar tussen het "wijzigingenpatroon' met betrekking tot de VOEG-lijst en tot de vragen over het defecatiepatroon?

Er blijkt geen enkel verband te bestaan tussen wijzigingen in de VOEG-scores en wijzigingen in de defecatieantwoorden. Degenen die in het ziekenhuis hun gezondheidstoestand thuis rooskleuriger inschatten dan ze thuis deden, blijken niet noodzakelijkerwijs degenen die her defecatiepatroon anders beoordelen. De beoordeling van her defecatiepatroon thuis wanuit de ziekenhuissituatie blijkt niet gekleurd door een 'thuis-was-alles-beter' tendens. De wijzigingen in het oordeel hieromtrent kunnen dus geinterpreteerd worden als beknopte, vereenvoudigde weergave dan wel als aanvulling, detaillering, precisering van of parafrasering op de thuis gegeven informatie.

\subsection{Discussie en conclusies}

7.5.1 Verandert, en zo ja in welk opzicht en in welke mate, het zelfoordeel van patiënten bij ziekenhuisopname betreffende de thuis ervaren gezondheid in thet algemeen en betreffende de stoelgang in het bijzonder? Eventuele vertekening door patiènten van informatie over thuis is, zoals aangegeven in $\$ 7.1$, verklaarbaar vanuit verschillend theoretisch perspectief, te weten: de emotionele impact (van ziekte en ziekenhuisopname), 'face-work' in een situatie die als 'bureaucratic format' onschreven kan worden, de 'cognitive dissonance theory', en het gewone tijdsverloop waaraan allen en alles onderhevig zijn.

Getracht wordt de werschillende (deel-jresultaten van het hier gerapporteerde onderzoek, voor zover in deze paragraaf relevant, te situeren binnen en te verklaren vanuit het betreffende theoretische kader. Samenvattend kan worden gesteld dat de onderlavige problematiek - overigens slechis een fractie uitmakend van het onderwerp "stoelgang' - niet binnen het kader wan éen van de genoemde theoretische constructies past. Eerder geldt dat verschiliende aspecten van het probleem verklaarbaar of begrijpelijk blijken vanuit wisselend theoretisch perspectief. Ook kan én bepaald fenomeen begrepen worden vanuit twee verschillende theoretische benaderingen. En tenslotte vertoont de problematiek ook aspecten die niet passen binnen een van de genoemde verklaringsmodellen.

7.5.2 In het ziekenhuis gevraagd naar elementen van hun gezondheidsbeleving thuis, antwoordden 21 orthopediepatienten vrij consistent vergeleken met de zelfrapportage thuis. De VOEG-scores bleken als geheel vrij stabiel; de divergenties deden zich voor" op onderdelen. Afwijkend bleak het retrospectieve oordeel met betrekking tot vraget over algeheel welbevinden: fitheid, slaperigheid, moeheid, eetlust, die men, retrospec- 
tief in het ziekenhuis met betrekking tot thuis, rooskleuriger inschatte. De perceptie vam de thuissituatie kan gekleurd zijn door 'pijnlijke' ervaringen tijdens ziekenhuisverblijf: de 'emotionele inpact' als verkllaring voor cen gewijzigde perceptie, althans rapportage, van de thuissituatie. Overigens kan deze wijziging eveneens worden begrepen in het theoretisch kader van 'face-work': men tracht in de 'bureaucratic format 'de schone schijn op te houden, men doet zich flinker voor dan men zich thuis wellicht voelde.

Eén klacht verdient aparte aandacht: in het ziekenhuis vond men dat men thuis minder last van pinnlijke voeten had gehad dan men thuís had gemeld. Dit is, in het licht van de genoemde 'cognitive dissonance theory', begrijpelijk voor patiënten die in het ziekenhuís pas écht pijnlijke voeten kregen (9 van de 21 respondenten hadden teen- of voetoperaties ondergaan). Bij uitbreiding van dit voorbeeld mag verwacht worden dat orthopediepatiënten, retrospectief gevraagd naar hun gezondheidsbeleving thuis, vooral de vragen over het bewegingsapparaat positiever "gekleurd" zouden beantwoorden (klachten over botten en spieren, over rugpijn, etc.) De desbetreffende subschaal in de VOEG-lijst scoorde echter als geheel niet significant verschillend op beide meetrnomenten. De overeenstemmingscoëfficiënt voor deze subschaal kwam overeen met de gemiddelde score van overeenstemming van de hele VOEG (voor de subschaal: $\mathrm{C}=0,79$ ).

Misschien is over het algemeen de situatie in het ziekenhuis van dien aard, dat idealisering van de thuissituatie retrospectief niet of nauwelijks plaatsvindt. De patiënt wordt immers geholpen aan de klachten waarvoor hij werd opgenomen.

7.5.3 Geconstateerd werd dat instabielere antwoorden op vragen van de VOEG-lijst vooral werden gegeven door personen met een laag klachtenniveau.

Dit verschijnsel lijkt verklaarbaar vanuit de theoretische reflecties betreffende 'facework': de patiënt wil blijkbaar beantwoorden aan de verwachtingen die men van een patiënt kan hebben, namelijk gezondheidsklachten te hebben, of - zoals in Tabel 7.7. wordt geillustreerd met betrekking tot de stoelgangfrequentie - lichamelijk overeenkomstig bestaande normen te functioneren.

Ook in wijsgerig antropologisch perspectief lijkt dit verschijnsel begrijpelijk. In de normale situatie, dus bij weinig lichamelijke klachten, verloopt het lichamelijke functioneren 'in de stillte der organen' (Leriche, 1936). In het normale leven is het lichaam voor de mens 'marginaal co-present'. Bij ziekte, aandoening, emstige handicap, kortom bij veel gezondheidsklachten, wordt het lichaam en het lichamelijk functioneren 'tot object van het thematisch bewustzijn' (Buytendijk, 1965). Mensen met veel gezondheidsklachten worden voortdurend geconfronteerd met de eigen lichamelijkheid en het eigen functioneren. Zij zijn voortdurend met zichzelf bezig, althans vaker of intensiever dan degenen die hun lichaam moeiteloos kunnen passeren. Daarom is niet alleen aannemelijk dat respondenten met een hoog klachtenniveau op meetmoment $t_{2}$ nog veel dezelfde klachten hebben als op $t_{1}$, maar ook dat hen op $t_{2}$ de klachten van $t_{1}$ nog goed voor ogen staan. Respondenten met een latag klachtemniveau hebben op $t_{2}$ niet alleen een (veel) geringer 'klachtenrepertoire' tot hun beschikking, waaruit zij kunnen putten. Maar de weinige klachten van ti zijn blijkbaar niet of nauwelijks geworden tot 'object van het thematisch bewustzijn'.

Overigens blijken theorieën omtrent de 'emotionele impact' minder geschikt voor 
verklaring van het hier besproken fenomeen. Daarin immers wordt gesteld dat vertekening van informatie optreedt in emotioneel geladen situaties, dus bij een hóg klachtenniveau. Over het algemeen geldt dat participanten aan dit deelonderzok niet in een situatie verkeerden die als zeer bedreigend of beangstigend moet worden gekenmerkt. Allen kwamen als lopend patiënt het ziekenhuis binnen, de meesten ondergingen een ingreep aan de extremiteiten, een overheersend ziektegevoel ontbrak.

7.5.4 Weten hóe nauwkeurig zickenhuispatienten over hun thuis ervaren gezondheid c.q. hun ontlastingspatroon rapporteren, of in welke richting wijzigingen in de zelfbeoordeling geinterpreteerd moeten worden, is slechts relevant indien deze informatie bijdraagt aan verhoogde kwaliteit van verpleegkundige anamnese, diagnose en inter.ventie. Voorondersteld hierbij is dat de verpleegkundige zorgverlening zich zou baseren en oriènteren op voor de patiënt normale, vertrouwde leefomstandigheden. Tot in hoeverre dient deze zorgverlening omtrent de stoelgang van ziekenhuispatienten te berusten op hun normale, vertrouwde defecatiepatroon?

De vraag is relevant gezien twee oppositionele uitgangspunten ten aranzien van de verpleegkundige zorgverlening. Enerzijds valt te argumenteren dat zorgverlening het meest gebaat is bij een voor de patiènt zo vertrouwd mogelijke gang van zaken. Dit standpunt kan bogen op een lange traditie in zowel de genees- als de verpleegkunde. Zo hield Galenus (in de tweede helft van de tweede eeuw na Christus) in zijn Mepi "Eow zijn volgelingen reeds voor "dat de natuur zich vehheugt over datgene waraan

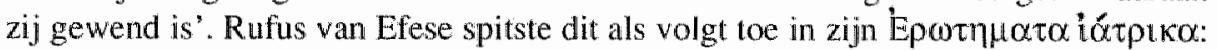
"Het letten op de gewoonten van zieken is het beste middel om onaangename complicaties te vermijden en de genezing ten snelste te bevorderen" (Bremer, 1972). Voor de professionele verpleging geldt dat historische handboeken, zoals Nightingales Notes on nursing (1859), in eerste instantie werden geschreven voor de thuisverpleging. "Thuisverpleging, alsook thuisbevalling of het stervensbed thuis, passen als voorbeelden binnen dit standpunt, waarvan de achterliggende gedachte is dat de mens zijn levens(en stervens-)opdracht het best vervuit in de eigen vertrouwde omgeving.

Daartegenover staat de opvatting dat ziek-zijn niet als een nomale, maar eerder als een uizonderlijke situatie beschouwd moet worden. Ziekte en ziekenhuisopname vormen vaak een cesuur in iemands leven", ziekenhuisopname is daarbij soms onvermijdelijk, als een noodzakelijk kwaad. Verveemding van de eigen vertrouwde leefsituatie kan in deze optiek zelfs heilzaam zijn, en kan dan bewust worden bevorderd. Verpleging in een instrumenteel-technisch hoog gespecialiseerde setting, of in een isoleercel, passen als voorbeelden binnen deze optiek. Achterliggende gedachte hierbij is dat de eigen, vertrouwde leefwereld niet altijd heilzaam is, maar ook pathogeen kan zijn.

Discussies omtrent de kwaliteit van de zorgverlening betreffen soms de vraag in hoeverre het 'eigen, vertrouwde' element ('eigen' verpleegkundige op de afdeling, eigen spulletjes, eigen meubels, ejgen huisdier mee naar het verzorgingstehuis) in de intramurale zorgverlening kan worden geduld of zelf's moet worden gestimuleerd. Continuiteit van zorg betekent dan 'levenscontinuiteit" (Grypdonck, 1989), of continuinteit van leefwereld.

Met betrekking tot de vormgewing van zorg kan men dus een 'homeo-situationele' 
dan wel een 'allo-situationele' positie innemen, dat will zeggen: de verpleegsituatie is, voor zover mogelijk, overeenkomstig met dan wel verschillend van de eigen, vertrouwde leefwereld. De zorg voor de stoelgang kan homeo-situationeel dan wel allo-situationeel worden gerealiseerd. Desgevraagd blijken drie van de vier patiénten voor de allo-situationele benadering te kiexen, althans zich daar bij neer te leggen (Van der Bruggen 1985, Van der Kooij 1987). 'De gewoonten van thuis in het ziekenhuis voortzetten kan gewoon niet', en 'Ik zal hier wel verstopping krijgen maar dat moet dan maar", behoren tot de explicaties bij deze keuze.

Hoewel men geneigd zou zijn de $25 \%$ patiènten te willen detecteren die hun problemen op homeo-situationele wijze wensen te zien opgelost - in haar onderzoeksrapport doet Van der Kooij (1987) aanbevelingen in die richting -, blijkt uit het replicatieonderzoek (cf. hoofdstuk 6 ) dat 'gehechtheid aan wc-rituelen van thuis' geen belangrijke rol speelt in de stoelgangproblematiek op de verpleegafdeling. Blijkbaar weten de "wc-ritualisten" zich in het ziekenhuis aan te passen. Waarschijnlijk ondergaat men een ziekenhuisverblijf als elk ander verblijf buitenshuis: ook op vakantie, op bedevaart, of anderszins op reis kan 'het gemak' verkeren in ongemak, waarmee men moet proberen te leven.

De conclusie is dat de verpleegkundige bij het intakegesprek minstens zo zeer moet vragen naar reisgewoonten als naar thuisgewoonten betreffende de stoelgang. 


\section{Samenvatting en discussie}

Veel patiènten, in het ziekenhuis opgenomen om zeer uiteenlopende redenen die vaak niets van doen hebben met aandoeningen aan het spijsverteringskanaal, vertonen klachten met betrekking tot de stoelgang. Dat is deervaring van veel verpleegkundigen, zonder dat precies is aan te geven om hoeveel patiènten het in deze gaat, noch wat de aard en de omvang is van die klachten. Deze problematiek was aanleiding tot de opzet van een aantal deelonderzoeken waarin aspecten werden bestudeerd wan de stoelgang - zowel de normale als cle problematische stoelgang, in het ziekenhuis alsook thuis en omtrent enkele waarvan hier wordt gerapporteerd.

De gefragmenteerde benadering van de problematiek resulteerde in gefragmenteerde kennis: aan het slot van deze verslaglegging moet worden bezien tot welke bevindingen de verschillende deelonderzoeken hebben geleid. Allereerst wordt daartoe, in $\$ 8.1$, een kort overzicht gepresenteerd van de verkregen kennis.

De gekozen benadering impliceerde uiteenlopende onderzoeksstrategieën. Kanttekeningen van methodologische aard worden gemaakt in $\$ 8.2$.

Stoelgangproblematiek van ziekenhuispatiënten kan, als behorende tot de 'verschijnselen, processen, situaties die verpleging en verzorging behoeven', worden gerangschikt bij de onderwerpen die in de verplegingswetenschap 'steeds vaker als onderwerp van onderzoek (worden) gekozen, Zij worden dan niet medisch (in termen van pathologie en therapie) gedefinieerd, maar verpleegkundig' (Philipsen \& van der Bruggen, 1989). Verpleegkundige definiëring verwijst naar theoretisering of theorievorming. Reflecties hieromtrent volgen in $\$ 8.3$.

Een paragraaf $(\$ 8.4)$ waarin praktische consequenties van de hier gepresenteerde deelonderzoeken worden geëxpliciteerd, sluit dit laatste hoofdstuk anf.

\subsection{Samenvatting van de resultaten}

De stoelgang vindt, althans in onze huidige Westerse samenleving, doorgaans in afzondering plaats; de uitscheiding gaat gepaard met gevoelens, wan privacy. In hoofdstuk 1 is nagegaan hoe, in de loop van eeuwen, men zich voor die stoelgang heeft teruggetrokken uit het openbare leven naar het 'privaat' als strikı privé-vertrek. Een 'pijnlijkheidsdrempel', aldus Elias (1982), werd opgeworpen, als resultaat van een langdurend civilisatieproces. In datzelfde proces verwierf ook de ziekenhuispatiént 
zich steeds mear privacy, ook al wordt die, in de belewing van veel patiènten, te weinig gerespecteend.

Privacy is, bij nadere beschouwing (in hoofdstak 2), een vaag begrip, met uiteenlopende betekenisdimensies en waaraan verschillende aspecten te onderkennen zijn. lemands privacy wordt, hetzij letterlijk hetzij figuurlijk, beschermd door een scheidswand, die in stand wordt gehouden door zowel materieel-organisatorische maatregelen en psychosociale structuren als door in de samenleving bestaande warden en normen. Als belangrijke conclusie van de conceptverheldering in hoofdstuk 2 geldt dat de genoemde scheidswand als flexibel, veranderlijk moet worden voorgesteld: men kan zijn privacy beschermen op verschillende wijzen en in werschillende mate, al naar gelang iemands maatschappelijke positie of de verschillende leeftijdsfasen waarin men verkeert, of namate het te beschermen aspect van iemands persoon het individu meer of minder kwetsbaar maakt. Er is dus reden te veronderstellen dat iemand bij ziekte c.q. bij ziekenhuisopname op een andere wijze dan anders privacygevoelig is met betrekking tot de stoelgang.

Problematiek bespreken, i.c. betreffende de stoelgang, impliceert: kunnen refereren aan het normale, het onproblematische. In hoofdstuk 3 worden humaan-biologische aspecten van het 'normale' defecatiepatroon onderzocht. Het normale patroon van ontlastingen vertoont twee kenmerkende structuren. Enerzijds is er een patroon dat wordt gekenmerkt door modaliteiten, namelijk 'later op de dag', "weinig" en 'keutel/knikkerachtige' ontlasting. Anderzijds is er een patroon dat wordt gekenmerkt door gedragsaspecten, namelijk "duur" en 'uitstel' van de stoelgang. Op deze twee basispatronen variëren de stoelgangpatronen van subgroepen, in het onderzoek onderscheiden naar geslacht en naar leeftijd.

Vervolgens werd, in hoofdstuk 4, gezocht naar determinanten wan belleving van de stoelgang, eveneens in een gezonde populatie. Beleving van de stoelgang bleek zich te uiten op vier verschillende wijzen - waarvan er drie verwijzen naar speciale gevoeligheden van mensen (namelijk voor hygiënische omstandigheden, woor ontlastingsgeuren en voor winden), en de vierde een globale houding ten opzichte van de stoelgang weergeeft, 'toilet-attitude'. Gevoelig voor hygiënische omstandigheden blijken vooral de vrouwen. Gevoelig voor winden, in de zin dat men zich er voor schaamt, zijn vooral de ouderen. Schaamte voor geuren manifesteren met name degenen die mag- en buikklachten hebben en die laxerende middelen gebruiken. Alles bij elkaar genomen blijken 'wc-problemen' vooral gerelateerd aan het geslacht: wc-problemen hebben met name vrouwen die klagen over lichamelijk ongemak bij de stoelgang of die laxerende middelen gebruiken.

In hoofdstuk 5 worden gedachtenvorming en onderzoek voortgezet omtrent privacygevoeligheid bij de stoelgang, nu met betrekking tot ziekenhuispatiënten. Op geleide van de conceptuele analyse in hoofdstuk 2 , is een instrument ontworpen om de privacygevoeligheid te meten van ziekenhuispatiènten met betrekking tot de ontlasting: de PrivacyGevoeligheids Vragenlijst (PGV). Uit het onderzoek bleek dat de PGV op aannemelijk valide en betrouwbare wijze de bedoelde privacygevoeligheid registreert, wat betreft zowel het gehele fenomeen 'privacygevoeligheid bij de stoelgang' als de vier specifieke dimensies, namelijk: 
a. Zintuigljk contact: de mate waarin men zintuiglijk contact bij de stoelgang vanzelfsprekend vindt;

b. Bemoeienis: de mate waarin men aanwezigheid bij of bemoeienis met de stoelgang vanzelfsprekend vindt;

c. Afzondering: de mate waarin men feitelijke afzondering bij de stoelgang belangrijk vindt;

d. Controle: de mate warininen het belangrijk vindt controle te hebben over de gehele (stoelgang-)situatie, met name over de informatie dienaangaande.

In het totaal blijken vrouwen gevoeliger voor privacy bij de ontlasting; daarnalast blijken zij gevoeliger voor de dimensie Afzondering. Degenen afkomstig wit een groot gezin beoordelen zichzelf als privacygevoelig bij de stoelgang. Degenen met een hoog opleidingsniveau scoren hoog op de dimensie Bemoeienis, zij met een lage opleiding daarentegen op de dimensie Zintuiglijk contact. Eveneens gevoelig op het punt van Bemoeienis blijken degenen die ervaring hadden met po-gebruik in het ziekenluis.

In hoofdstuk 6 werd bezorgdheid van ziekenhuispatienten omtrent hun stoelgang onderzocht in relatie tot onder meer veranderingen in het defecatiepatroon na ziekenhuisopname. In de onderzoeksgroep blijkt $41 \%$ van de patiënten zich zorgen te maken over de stoelgang. Die bezorgdheid blijkt vooral gerelateerd aan fixatie op ontlastingsproces en -produkten, alsmede aan een veranderde ontlastingsfrequentie. Voor pogebruikers blijken schaamte en de instabiliteit van de beddepan belangrijke bezorgdheidsfactoren.

Als praktische consequentie aangaande het intake-gesprek komt in hoofdstuk 6 aan de orde hoe patiènten met 'stoelgang-risico' bij opname in het ziekenhuis gedetecteerd kunnen worden, op voorwaarde dat de verpleegkundige zou kunnen beschikken over betrouwbare informatie van de patiënt over diens thuis ervaren gezondheid in casu over het ontlastingspatroon thuis:

In hoofdstuk wordt de betrouwbaarheid van de patiënteninformatie na ziekenhuisopname nader onderzocht. Men bleek in het ziekenhuis betrouwbaar te informeren over de thuis ervaren gezondheid. Met name gezondheidsklachten die in meer of mindere mate aan de stoelgang gerelateerd zijn, blijken voor en na opname betrouwbaar gerapporteerd. Echter, over aspecten van de nomale stoelgang thuis blijken patienten in het ziekenhuis soms voldoende betrouwbaar (frequentie van de stoelgang, wcgewoonten), soms weinig (eventueel vast moment) of ook nie betrouwbaar (hoeveelheid faeces) te infomeren. Uit het onderzoek bleek geen inzichtelijk patroon in de op onderdelen wissellende betrouwbaarheid. Waaruit volgt dat de betrouwbaarheid van informatie over het normale ontlastingspatroon thuis, verkregen in het ziekenhuis, (nog) moeilijk voorspelbaar is.

\subsection{Methodologische reflecties}

De per thema wisselende betrouwbaarheid van de zelfrapportage door patiènten is een reden te meer voor enkele methodologische kanttekeningen. In de hier gerapporteerde deelonderzoken werd niet gerefereerd aan het oordeel van de verpleegkundige om trent 
probliemen van patienten met de stoelgang, met name wat betreft de privacygevoeligheid van dezen bij de ontlasting.

Het lijkt voor de hand te liggen ervan uit te gaan, dat verpleegkondigen zouden beschikken ower de meest juiste patiënteninformatie. Verpleegk undigen verzekeren niet alleen de 24 -uturs continuîtteit van zorg, maar eveneens zou een empathische benadering van de patiënt resulteren in inzicht in wat de patiënt feitelijk beroert (Mansfield 1973, Forsyth 1979, Malinsky 1986).

Met betrekking tot privacygevoeligheid van patiënten betreffende de stoelgang kon de vraag worden gesteld of, en zo ja in welke mate, de perceptie ervan door de verpleegkundigen overeenkomt met de zelfbeoordeling door de patiënten. Deze vraag werd beantwoord in het kader van het deelonderzoek waarover in hoofdstuk 5 werd gerapporteerd. Aan de hand van de desbetreffende data werd een instrument ontwikkeld en gevalideerd voor meting van privacygevoeligheid van ziekenhuispatiënten bij de stoelgang (Stijnen, 1988). Factoranalyses resulteerden in vier subschalen, waarvan er én werd onderverdeeld in twee kleinere schaaltjes:

\section{Vanzelfsprekendheid: Zintuiglijke inbreuken (VZ)}

1.1: betreffende gehoor en reuk (VZ1)

1.2: betreffende aanwezigheid personeel (VZ2)

2. Vanzelfsprekendheid: Bemoeienis (VB)

3. Belangrijkheid van maatregelen: Zintuiglijke inbreuken (BZ)

4. Belangrijkheid van maatregelen: Bemoeienis (BB)

Een aantall statements betreffende de privacygevoeligheid werd behalve aan de 92 patiënten eveneens voorgelegd aan 64 verplegenden, namelijk aan degenen die naar eigen zeggen de betreffende patiënten het best kenden. Deze verplegenden werd gevraagd de items te scoren zoals zij vermoedden dat de betreffende patiënten zelf dat zouden doen. Op de scores door de verpleegkundigen werden eveneens factoranalysen uitgevoerd. Deze resulteerden in vier subschalen die globaal overeenkwamen met die van de patiëntenlijst. Ook hier werd een subschaal, hoewel een andere dan bij de patiënten. onderverdeeld in twee kleinere schaaltjes:

1. Verplegenden: Vanzelisprekendheid: Zintuiglijke inbreuken (VVZ)

2. Verplegenden: Vanzelfsprekendheid: Bemoeienis (VVB)

3. Verplegenden: Belangrijkheid van maatregelen: Zintuiglijke inbreuken (VBZ)

3.1: betreffende het bezoek (VBZI)

3.2: zich afzonderen (VBZ2)

4. Verplegenden: Belangrijkheid van maatregelen: Bemoeienis (VBB)

De mate van overeenstemming verpleegkundigen-patiënten is weergegeven in tabel 8.1.

Tussen wat de patiënten invulden en wat de verplegenden dachten dat de patiënten zouden antwoorden werd geen samenhang gevonden. 
Tabel 8.1 Overeenstemming tussen patiënten- en verplegenden-antwoorden op de PrivacyGevoeligheids Vragenlijst

\begin{tabular}{lrl} 
Subschalen & $r$ & $p$ \\
\hline$W Z 1-W Z$ & 0.01 & 0.90 \\
$W Z Z-W Z$ & 0.12 & 0.26 \\
$W B-W B$ & 0.12 & 0.27 \\
$B Z-V B Z 1$ & 0.12 & 0.25 \\
$B Z-$ VBZ2 & -0.08 & 0.45 \\
$B B-$ VBB & 0.04 & 0.72 \\
\hline
\end{tabular}

Voor dit opmerkelijke resultaat bestaan wel enkele verklaringen, onder andere van methodologische aard. De geconstrueerde subschalen bij patiënten en verplegenden kwamen niet helemaal met elkaar overeen: zij bestonden soms grotendeels uit verschillende items en maten dus wellicht niet dezellde genuanceerde deelaspecten van privacygevoeligheid. Verder kan de relatieve complexiteit van de PGV een belemmering zijn geweest bij het scoren van de statements. Stijnen (1988) maakt zelf melding van dit probleem, reeds in hoofdstuk 5 gesignaleerd.

Anderzijds bleek dat de subschalen, in de lijsten onderscheiden bij patiënten en verplegenden, global genomen wel dezelfde dimensies meten van privacygevoeligheid bij de stoelgang. De boven benoemde bezwaren geven geen uitputtende verklaring voor het totale gebrek aan overeenstemming tussen beide groepen. De conclusie, ook door Stijnen getrokken, lijkt onvermijdelijk: de verplegenden kennen 'hun' patiënten niet wat betreft datgene wat er in hen omgaat.

Overigens ligt deze conclusie in de lijn van eerder verplegingswetenschappelijk onderzoek. Reeds in 1959 toonde Whiting aan hoe met de voortschrijding van het professioneel niveau van verpleegkundigen hun vermogen tot inschattingen op patiëntenniveau afnam (Whiting, 1959). Maastrichts verplegingswetenschappelijk onderzoek leidt nogal eens tot soortgelijke conclusies, of het nu gaat om privacygevoeligheid (Stijnen, 1988), dan wel om het inschatten van angstgevoelens (Klop 1984. Schulkens 1987), het beoordelen van eenzaamheidsproblematiek (Nijssen, 1987) of van zelfzorgvermogen (Kalter 1987, Schiltmans 1987, Grüschke 1990), of het inschatten van pijn (Abu-Saad, 1990): met betrekking tot vooral de basisbehoeften weten verplegenden niet echt hoe het met 'hun' patiènten gaat.

Uiteindelijk mag deze conclusie weinig verrassend heten. Ziek-zijn immers wordt, bij nadere analyse, gekenmerkt door 'anders-zijn', waarbij het andere, de ziekte zich bijna per definitie onttrekt aan discursieve kennis - zowel bij de naaststanden van de zieke, van wie hij "vervreemdt', alsook bij de zieke zelf (Van der Bruggen 1977, 1987). Dit gebrek aan kennis betreft ook en vooral de basale aspecten van het menselijk bestaan, de 'basisbehoeften', terwijl meer kennis is vergaard omtrent de omgeving van de patiènt, de leefwereld, de betekemis van de dingen daarin, de beleving van tijd en ruimte (Van den Berg 1952, Poslavsky 1956, Ellerbeck 1961, Bremer 1972, Visser 1984). Op het gebied dus waar de verpleegkundige de essentic van haar beroep uitoefent, namelijk het voorzien in basisbehoeften van patiënten, blijkt hel haar aan gewogen kennis en inzicht te mankeren. Overigens kan betwijfeld worden of verpleeg- 
opleidingen er alles aan doen, leerlingen en studenten deze kennis en dit inzicht bij te brengen (ct. Unleiding 8 ). Wat dit betreft zijn Whitings bewindingen niet verwonderlijk, aangezien hoe hoger men stijgt in de hierarchie van verpleegopleidingen, hoe minder men werkt in de directe patiënt-verplegende-relatie.

\subsection{Theoretische overwegingen}

De deelonderzoeken waruit dit proefschrift is samengesteld konden soms natuelijks ingekaderd worden binnen bestaande verklaringsmodellen of wetenschappelike theorieen. Soms, bijwoorbeeld in hoofdstuk 7, gebeurde dit wel: de problematiek rond "putiënt, privaat en privacy" werd belicht vanuit enkele uiteenlopende theoretische perspectüeven, zonder dat daarbij overigens kon worden geopereerd vanuit een expliciete verplegingswetenschappelijke stellingname.

Als argument werd in de deelrapportages soms gewezen op het ontbreken van voldoende literatuur over (deel-)aspecten van de bestudeerde problematiek, soms op afwezigheid van een verplegingswetenschappelijk perspectief in beschikbare publikaties. Ook al werd over de normale en de problematische stoelgang, thuis en in het ziekenhuis, weinig gepubliceerd, de stoelgang als normaal en problematisch heeft in de verpleegkundige discipline (uiteraard) een brede bekendheid. In de bestaande verplegingswetenschappelijke theorieèn wordt de excretie niet genegeerd. Maar de wijze waarop de uitscheiding daarin wordt behandeld, maakt duidelijk waarom die theorieèn miet in abmmerking kwamen als theoretisch kader voor de verschillende deelonderzoeken. De bestaande nursing theories, het merendeel wan Amerikaanse oorsprong en vele ervan logisch-positivistisch geinspireerd, hanteren veelal een overwegend mechanistisch mensbeeld, warbij de uitscheiding wordt opgevat als lozing van afvalstoffen na een verbrandingsproces (bijvoorbeeld bij Johnson, 1980), of als een mechanisme van stimuli en responsen (bijvoorbeeld bij Roy, 1984). Het menselijke, existentièle van de stoelgang krijgt niet de nodige aandacht. Meer historistisch geinspireerde theorieën (de indeling is van Silva en Rothbart, 1984), waarbij historische en culturele dimensies van de stoelgang meer tot hun recht zouden komen, missen veelal de nodige geoperationaliseerde concepten, premissen en proposities ter hypotheseformulering en empirische toetsing.

Uiteindelijk werd gekozen voor een exploratieve benadering van de (deel-)aspecten van de geviseerde problematiek - naast, duidelijk geëxpliciteerd, een historisch-fenomenologische beschrijwing van het aspect 'privacy bij de stoelgang'. In de empirische gedeelten echter werden, indien relevant, onderzoeksresultaten belicht vanuit antropologisch-verpleegkundig perspectief. Dit perspectief is dat warmee de onderzoeker het meast vertrouwd is (cf. Van der Bruggen 1977, 1987a, 1987b, 1989). Aam het einde van deze studie rijst de vraag, in hoeverre een antropologisch-verpleegkundig perspectief heeft bijgedragen aan inzicht in de hier bestudeerde problematiek, en of en zo ja, onder welke voorwaarden dat perspectief meer ten nutte kan worden aangewend.

Feitelijke of dreigende stoomis van een basale menselijke functie, als de uitscheiding, kan het gehele menselijke bestaan beïnvloeden, "aantasten". Bij analyse van het menselijke bestaan, op geleide van auteurs uit de wijsgerige antropologie (Heidegger, 
Merleau-Ponty, Sartre) en de medische antropologie (Buytendijk), blijkt de existentie omschreven te kumen worden als een excentrische 'beweging' vanuit het existerend subject naar de wereld. In deze beweging zijn 'achtereenvolgens' enkele elementen te onderkennen.

'Vooreerst' is er de mens, het existerend subject zelf, die zich in zijn eigen zelf, zijn eigen ik aangetast kan voelen, ook bij uitscheidingsproblemen. Wat van het subject het meest $k$ wetsbaar is, kan docr middel van privacybescherming behoed worden. 'Vervolgens" is er het aspect van de lichamelijkheid. Als ziekte, beperking, onvermogen of handicap iemands bestaan aantasten, ervaart men nief alleen een lichaam te zijn, maar ook te hébben - als een hinderlijk voorwerp, dat in sommige medische situaties aan anderen moet worden toevertrouwd.

Vanwege het lichaam is men 'in" de tijd en 'in' de ruimte. Het lichaam 'maakt" tijd en ruimte. Het is de spil van iemands leefwereld ('le pivot du monde', Merleau-Ponty), waarvan niet alleen de dingen maar ook de medemensen deel uitmaken. Het menselijke zijn is aldus te zien als samen-zijn: 'Sein ist Mit-sein' (Heidegger).

Aan het menselijke bestaan kunnen, 'gleichursprünglich' (Heidegger), bovengenoemde facetten 'achtereenvolgens' worden onderscheiden. Het beeld van een keten, de 'existentiële keten', waarbij deze facetten als verschillende schakels in elkaar grijpen, is in feite dus een zwakke voorstelling van zaken - hoewel de minst slechte beeldspraak voorhanden.

Ziek-zijn kan als zo ingrijpend in het menselijk bestaan worden ervaren, dat gevolgen merkbaar worden ten opzichte van verschillende elementen van het bestaan, dat wil zeggen: in verschillende 'schakels van de existentiele keten'. Vanuit antropologisch perspectief bezien hebben ziek-zijn en lichamelijk functioneren, inclusief de uitscheiding, een wederkerige relatie.

Voor de ziekenhuispatiënt komt daar nog bij dat ook de opname en het verblijf op de verpleegafdeling als (zeer) ingrijpend ervaren kunnen worden. Ook dit zou, minstens ten dele, ontregeling van de stoelgang kunnen verklaren. Verstoring van het defecatiepatroon indien men voor enige tijd uithuizig is, is voor velen een bekend verschijnsel.

Wanneer ziekte of aandoening het menselijk bestaan ingrijpend aantasten, en hulp geboden is, kan de persoon een beroep doen op verschillende werkers in de gezondheidszorg. Worden de problemen ter leniging aan de verpleegkundige aangeboden of, indien dit niet expliciet gebeurt, (h)erkent deze vanuit het eigen beroepsperspectief de problematiek als ressorterend onder eigen deskundigheid en beroepsverantwoordelijkheid, dan is sprake van een verpleegprobleem. De verpleegkundige helpt de zieke als mens zo normaal mogelijk te existeren. Verplegen is het op deskundige wijze hanteren van de leefwereld van de zieke mens. Daarnaast kan worden gesteld dat de verpleegkundige de patiënt benadert, of: zich als het ware toegang verschaft tot de aangetaste existentie van de zieke mens, via het aspect van diens lichamelijkheid. Zo draait het verpleegkundig handelen om twee assen, namelijk de lichamelijkheid van de patiënt (én van de verplegende), en het deskundig hanteren van diens leefwereld.

Het hier beschreven antropologische perspectief kan ertoe bijdragen bepaalde aspecten van de normale of de problematische stoelgang inzichtelijk voor te stellen. De stoelgang is een gebeuren waarbij het individu kwetsbaar is, waarbij kenmerken van lichamelijkheid zich kunnen opdringen, dat structurerend kan zijn van tijd en plaats, en 
waarbij bepaalde regels worden gesteld alan de omgang met de medemens. In de loop van enkele deelonderzoeken konden, vanuit dit perspectief, bepaalde resultaten tenminste begrepen wordien (bijvoorbeeld: hoe lager iemands kllachtenniveau, des te instabieler de zelfrapportage na ziekenhuisopname over de thuis ervaren gezondheid, cf. hoofdsuk 7).

Vanuit ditzelfde perspectief werd, in hoofdstuk 1, aannemelijk gemaakt dat na ziekenhuisopname iemands "pijnlijk heidsdrempel" (in de zin zoals gebruikt door Elias) hoger of ook wel lager zou kunnen worden. Welnu, een theorie die een feit voorspelt ến het tegendeel van dat feit, is geen theorie. Dit is waarschijnlijk de belangrijkste reden waarom geen empirisch onderzoek is uitgevoerd gebaseerd op een antropologisch-verpleegkundige visie noch op vergelijkbare theoretische overwegingen: zij bevinden zich in een voorfase van operationalisering. Toetsbare uitspraken zijn er feitelijk (nog) niet wit af te leiden.

Anderzijds hebben de deelonderzoeken wel bijgedragen aan meer inzicht in de stoelgang als een normaal menselijk gebeuren. Als onderscheiden facetten van het bestaan (de 'schakels' van de 'existentiéle keten") werden belicht:

- het individu, kwetsbaar in situaties die als vernederend ervaren kunnen worden;

- het lichaam, dat zich doet gevoelen, bij de normale maar vooral ook bij de problematische stoelgang;

- de tijd, dat men de stoelgang uitstelt, of die men besteedt aan de uitscheiding, of dat de ontlasting op zich laat wachten, dan wel als aandrang gevoeld wordt;

- de ruimte, die sommigen aankleden als een gezellig interieur, een 'verblijf', en die voor anderen een functionele ruimte is, een 'vertrek'; die voor sommigen in ieder geval in eigen, vertrouwde omgeving, en voor weer anderen overál gelegen kan zijn; de plaats die voor sommigen 'het gemak' betekent, voor anderen het ongemak;

- de dingen die een speciale betekenis kunnen krijgen, bijvoorbeeld wanneer zij op de door sommigen zo gewenste hygiëne betrekking hebben, of wanneer zij ertoe bijdragen de stoelgang te bespoedigen;

- de ander, met wie de omgangsregels strikt zijn waar het de ontlasting betreft; door wie men liefst niet gestoord will worden; die men liefst ook niet zou hinderen met stank of geluid; die men toch ook soms nodig kan hebben voor intieme zorg; van wie men ook afhankelijk kan zijn.

Deelonderzoeken dragen dus bij aan inzicht in aspecten van de normale en ontregelde stoelgang. In een volgende fase van onderzoek zouden, met betrekking lot de stoelgang thuis of in het ziekenhuis, bepaalde veronderstellingen tot in hypothesen geformuleerd kumnen worden, om zodoende te komen tot theorie-toetsing.

\subsection{Praktische consequenties en aanbevelingen}

Behalve bovenstaande aanbevelingen tot verder onderzoek, volgen uit de deelonderzoeken ook de onderstaande praktische consequenties en aanbevelingen.

8.4.1 Het 'nomale defecatiepatroon' bestaat niet. Het normale patroon heeft twee 
onderscheiden dimensies, namelijk de ene gebonden aan de modaliteiten 'vorm' en 'hoeveelheid" van de faeces en "tijdstip' van de stoelgang, de andere aan de kenmerken 'duur' en 'uitstel" van de ontlasting. Subgroepen - te weten: jongere en oudere mannen en jongere en oudere vrouwen - varièren elk op voor hun karakteristieke wijzen op deze twee "basis-patronen".

Indien de verpleegkundige, in verband met diagnose of interventie, probeert inzicht te krijgen in, aan te sluiten op of in te grijpen in het normale ontlastingspatroon, verdient het aanbeveling zich te orienteren op zowel de twee basispatronen inclusief op de varianten per subcategorie.

8.4.2 Van de beleving van de normale stoelgang worden vier aspecten beschreven, die gerelateerd zijn aan bepaalde categorieën mensen.

- Vrouwen blijken gevoeliger voor hygiëne op de wc. Vrouwen met lichamelijk ongemak of gewend aan laxerende middelen, hebben meer in het algemeen meer wc-problemen.

- Ouderen schamen zich meer voor winden.

- Mensen met maag- en buikklachten en laxerende middelen zijn meer geurgevoelig.

- Een problematische houding ten opzichte van de stoelgang vertonen: mensen met maag-en buikklachten, degenen die laxerende middelen gebruiken, die vaak vinden dat de eigen ontlasting stinkt, die weinig tijd besteden aan de stoelgang, die zelf winderig zijn.

De risicogroepen ten aanzien van de stoelgangproblematiek zouden niet alleen in bovengenoemde categorieën vroegtijdig onderkend dienen te worden, maar ook bij opname in het ziekenhuis als zodanig dienen te worden aangemerkt.

8.4.3 De PrivacyGevoeligheidsVragenlijst (PGV) biedt de mogelijkheid privacy(over)gevoeligheid van ziekenhuispatiënten bij de stoelgang te bepalen. De PGV valt uiteen in vier subschalen, voor meting van vier dimensies van privacygevoeligheid, namelijk betreffende Zintuiglijk contact, Bemoeienis, Afzondering en Controle. Naar PGV-totaalscore blijken vrouwen privacygevoeliger. Gevraagd naar het (totale) zelfoordeel, blijken patiënten afkonstig uit grotere gezinnen gevoeliger voor privacy. Privacygevoelig op een of enkele van de vier onderscheiden dimensies blijken vrouwen (Afzondering), hoger opgeleiden (Bemoeienis), lager opgeleiden (Zintuiglijk contact), en patiënten die bij een eerder ziekenhuisverblijf de ondersteek hadden gebruikt (Bemoeienis). Overigens behoeft de PGV inkorting en verfijning.

Het verdient aanbeveling te onderzoeken in welke mate privacygevoeligheid bij de stoelgang - in haar geheel alsook wat betreft de vier onderscheiden dimensies - al bij opname van de patiënt op de verpleegafdeling kan worden vastgesteld. Een dergelijke vaststelling kan leiden tot vroegtijdige (h)erkenning van patiënten met "stoelgang-risico' met alle preventieve voordelen van dien. Vervolgonderzoek kan dan betrekking hebben op doeltreffendheid van preventief verpleegkundig handelen.

8.4.4 Van ziekenhuispatiënten, niet opgenomen vanwege aandoeningen aan het spijsverteringskanaal, bleek in het deelonderzoek $41 \%$ zich zorgen te maken over de 
sollgang: Bij mogelijke generalisering van dit gegeven liggen op een "gewone" verpleegafdeling van 30 patienten er 12 die zich zorgen maken over de ontlasting, met mame over obstipatie of en verminderde ontlastingsfrequentie. Ower het geheel gezien, alsook meer in het bijzonder bij de wc-gebruikers, blijkt die bezorgdheid wooral gerelateerd aan gefixeerdheid op ontlastingsproces en -produkten, alsook aan een veranderde ontlastingsfrequentie. Voor po-gebruikers blijken schaamte en de onstabilitett van de beddepan belangrijke factoren van inwloed.

Vanuit en optiek van verpleegkundige preventie lijkt het relevant te pogen patiènten met 'stoelgang-risico' te detecteren bij opname op de verpleegafdeling. Een kenmerk van de probleempatiénten (de totale groep alsook, meer beperkt, degenen die van de we gebruik maken) is het gebruik thuis wan laxerende middelen (medicijnen en natuurlijke produkten). Dit zou, bij opname op de afdeling, al een eerste indicatie kunnen zijn. Tijdens het ziekenhuisverblijf zijn het de hierboven genoemde indicatoren die naar het vóórkomen van problemen verwijzen.

Opmerkelijk bij de po-gebruikers is dat aan de bezorgdheid veel variabelen zijn gerelateend die te maken hebben met de directe zorgverlening. De verplegenden en verzorgenden moeten dan ook:

- gevoelens van schaamte van patiënten die op de po gaan respecteren, zo mogelijk reduceren;

- deze patienten stabiel op de ondersteek platsen;

- extra zorg dragen voor frisse lucht;

- stimuleren, althans toestaan dal wc-rituelen van thuis, indien men daaraan gehecht is, zoveel mogelijk gepraktiseerd kunnen worden;

- gelegenheid bieden tot handen wassen na de ontlasting.

Verpleegopleidingen moet worden aanbevolen bovengenoemde interventies in de trainingsprogramma"s op te nemen c.q. deze bijzondere aandacht te geven.

Bij verwolgonderzoek verdient het aanbeveling 'bezorgdheid omtrent de stoelgang' verder te differentiëren naar diverse categorieën ziekenhuispatiënten, bijvoorbeeld interne versus chirurgische patiënten.

8.4.5 Belangrijk voor de verpleegkundige anamnese en diagnose is het gegeven dat inlonmatie aan de patient in het ziekenhwis gevragd over de thuis ervaren gezondheid over het algemeen betrouwbaar is. Vragen over het algemene welbevinden (fitheid, moeheid, slaperigheid, eetlust) worden retrospectief rooskleuriger beantwoord. Dit geldt niet, althans bij de orthopedische patiẻnten in het deelonderzoek, voor vragen over meer specifieke gezondheidsklachten.

Informatie over de stoelgang thuis, retrospectief in het ziekenhuis verstrekt door de patient, is deels betrouwbar, deels niet. (On)betrouwbaarheid op dit punt houdt geen verband met (on)betrouwbaarheid ten aanzien van de vragen over de thuis ervaren gezondheid. Voor de verpleegkundige lijkt het overigens niet relevant uitsluitend aan te sluiten bij de thuisgewoonten van de patiënt betreffende de stoelgang. De meeste patienten willen in het ziekenhuis hun stoelganggewoonten wel aanpassen - of leggen zich neer bij wat hen owerkomt op dit punt. Voor inzicht in eventueel te werwachten stoelgangproblemen lijkt het relevant zich eveneens te oriënteren op iemands ontlastingspatroon bij uithuizigheid. 


\section{Summary}

Many patients admitted to a hospital for a number of reasons many of which have very little to do with the alimentary tract, complain about inadequate bowel function. Nurses are, professionally speaking, familiar with those complaints that, until now, have bardly ever been investigated. Nearly no information is available about for example the number of patients commonly suffering from bowel problems, the nature of the meant troubles, in short about the extent and seriousness of defecation problems in hospitalized patients. This provided a challenge for research and finally led to a series of research projects some of which are reported in this study, in mutually independent chapters.

In our western society bowel movement or defecation takes place usually in privacy. In chapter 1, a historical overview of bowel habits, especially among sick persons, and their relationship to privacy is given. During centuries bowel activities were, in a continuously civilized process, declined from public to private life. As a result of civilization, expectations raised by society, and rules of sanitary conduct, a sense of shame and embarrassment accompanied bowel actions inducing a change from public to private life.

Privacy as a concept is rather vague and ambiguous. In chapter 2 , privacy as a concept is elaborated, resulting in a general definition with distinct dimensions. Indicators of privacy in relation to bowel action among hospital patients were indentified. One of the facts described was the so called 'inaginary membrane' which is supposed to protect somebody"s privacy. This 'membrane' must be represented as changeable, and changing indeed in various circumstances and in relation to different vulnerable aspects of a person's life. This makes it acceptable to state that feelings of excretory privacy may alter in cases of illness and admission to hospital.

Chapters 3 and 4 report on research studies dealing with the human-biological and the psychological aspects of bowel function in a healthy population. In chapter 3 a research study is reported, involving a population of 90 healthy participants selected by means of convenient sampling. The participants were asked to keep diaries for two weeks, on the process and products of bowel function. Together with information about stools, data were gathered about health and wellness, nutrition, medication, sanitary practices, and others. Among the human-biological aspects, two different stool patterns were found. One is related to modalities of defecations (i.e: to form and quantity of stools and the moment of defecation), and the other to the functional aspects of defecation (i.e.: its delay and duration). Results of this study showed no single bowel pattern. Defecation patterns of the participants in this study when classified by sex and 
age, showed divergent variations on the two marked pattems.

Chapter 4 deals with experienced feelings related to defecation in the same healthy population. Four modalities of experienced feelings appeared; three of them are related to issues of sensitivity, namely: susceptibility for sanitary cleanliness, for excretory odours and for flatulency, and the fourth being a global attitude to bowell activity. Wonen appeared especially susceptible for sanitary cleanliness. Susceptibility for flatulency was found in the elderly. Susceptiblity for excretory odours appeared among those with stomach and abdominal complaints and those using laxatives. In summary, bowel problems seemed to be more common among women suffering from a malfunctioning bowel, or using laxatives.

Chapter 5 presents a research study on feelings of excretory privacy. A sample of 92 patients from medical units was selected. Guided by the results of the concept analysis, elaborated in chapter 2, a Likert type instrument was constructed and validated for measuring the needs of hospital patients for excretory privacy. This instrument appeared to measure, on acceptable levels of validity and reliability, these needs as well as the four theoretically distinguished dimensions of excretory privacy. The four dimensions are: sensory contact, interference, seclusion and control.

Women are, generally speaking, more sentitive for excretory privacy, and also for the privacy dimension of seclusion. Sensitive for the interference dimension are those with a higher educational level. Persons with a lower educational level appeared to be sentitive for the dimension of sensory contact. Also sensirive for the interference dimension are persons that, formerly as hospital patients, happened to use a bed-pan.

Research on bowel worry and concern among hospital patients is reported in chapter 6. This study was set up originally as a replication of Wright's (1974) research on Bowel function in hospital patients, and elaborated later as an enlarged or "constructive replication sudy" (Connelly, 1986).

A population was selected including 160 hospital patients from both medical and surgical wards, in two academic and two non-academic general hospitals. Structured and non-structured questions were asked about bowel function, sanitary practices, feelings of privacy, shame and embarrassment as well as about medication, nutrition and (other) nursing and environmental factors.

Data gathered showed that $41 \%$ of the patient population studied evidenced worry and concern about bowel functioning after admission to the hospital. For the whole group as well as for those who used the toilet, worry and concern appeared in relation to fixation on both bowel processes and products, and also to a changing frequency of defecation. For those using bedpans, feelings of shame and embarrassment as well as the unstable position when sitting on the bed-pan appeared to be the most important reasons for worry and concern.

From a prevention point of view in nursing, selecting patients with "potential for bowel worry" when admitted to the ward, seems relevant. Given the fact that many patients with those problems used laxatives when at home, the use of laxatives could be one of the indicators.

In order for the nurse to make an accurate assessment of a patient on admission, reliable information about the patient's perception of his sickness and wellness at home, including his bowel habits and pattems are important. In chapter 7 , the reliability of 
information provided by patients when admitted to hospital was studied.

A sample of 21 patients on a waiting list for admission to an orthopedic department of a general hospital was selected. Data were collected on the (future) patient's health and wellness as well as on their bowel activities at home. The same data were collected, retrospectively, few days after admission to the hospital. Data collected at home and after admission to the hospital were analysed.

The information concerning the patient's health and wellness at home including bowel activities appeared to be reliable. However, some aspects of nomat bowel habits at home are reported with less reliability or without any reliability at all. No justification for this findings could be identified. Consequently, it remains difficult to predict how reliable the information will be about bowel function at home from patients admitted into the hospital.

Finally, in the concluding chapter 8 practical, methodological and theoretical considerations are summarized and implications for theory development, research and the practice area are drawn. 


\section{Sommaire}

De nombreux malades, hospitalisés pour des raisons très variées et qui n'ont rien à voir avec des affections de l'appareil digestif, se plaignent après quelques jours d'hospitalisation d"un mauvais fonctionnement du transit intestinal. Les infinmières sont, professionnellement parlant, habituées à ces plaintes, sans pour autant pouvoir indiquer ni le nombre de patients souffrant de ces troubles, ni l'ampleur, ni la vraie nature de ces inconvénients. En outre, les problèmes mentionnés n'ont pas fait jusqu'à ce jour l'objet de publications scientifiques infirmières ou autres. Ce sujet a été le point de départ d'un série de projets de recherche dont certains sont présentés ici dans sept chapitres indépendants les uns des autres.

Dans notre sociêtế occidentale aller à la selle est du ressort de la vie privée. Un aperçu historique de la défécation est donné dans le chapitre 1, en particulier de la situation des maiades en relation avec les exigences de la vie privée. Dans une évolution continue de civilisation qui couvrit des siècles, la défécation fut retirée de la vie publique et reservée à la vie privée. Le résultat fut l'établissement dans la société moderne de règles de convenances pour les conduites excrétoires. Celles-ci sont marquées par la gêne et la pudeur; les besoins d'intimité se font sentir.

L'intimité ou la vie privée s'avère avoir une signification peu précise. Le chapitre 2 présente une analyse de l'intimitế, menant à une description, une définition et une opérationalisation de ce phénorinène en général et de ses parties composantes en particulier. L'analyse a permis de préciser la vie privée des malades hospitalisés, plus particulièrement en relation avec la défécation. Entre la vie publique et la vie privée une 'membrane' imaginaire est supposée protéger les zones les plus vulnérables de la personne. Cette "membrane" est à concevoir comme de nature à s'adapter, et comme changeant effectivement selon les circonstances. Il resulte de ceci que des exigences d'intimité, et plus particulièrement la 'pudeur excrétoire', peuvent se manifester de manières différentes dans des cas de maladies et d'hospitalisation.

Le modèle normal de la défécation humaine est étudiée dans les chapitres 3 et 4 , dans une population contenant 90 personnes saines, choisies par un moyen 'd'échantillonage simple' ('convenient sampling'). II était demandé aux participants de remplir un questionnaire sur leur état de santé ainsi que sur la physiologie, le vécu et le comportement excrétoires. De même il leur était demandé de noter, dans un journal pendant 15 jours, les données détaillées concernant l'élimination, la nourriture et les boissons, et éventuellement la prise de médicaments et de laxatifs.

Pour les aspects physiologiques de la défécation (chapitre 3), deux modèles différents 
furent trouvés, l"un relatif aux modalités de lélimination, cest à dire: l"aspect, la consistence, la quantité des selles et le moment précis de la défécation, l"autre relatif aux aspects comportementaux, c'est à dire: la remise et la durée de la défécation. Une des conclusiong est qu"il n'existe pas un seul modèle d"excrétion: les sous-groupes dans la population étudiée, divisée selon les sexes et en classes d'âe, se rêpartissent dans les deux modèles trouvés.

Une recherche des expériences vécues parmi les mêmes participants bien-portants est rapportée dans le chapitre 4. Quatre modalités différentes d'expériences quant à l'élimination ont été identifiées, dont trois liées à des sensibilités déterminées: la sensibilité à l'hygiène sanitaire, aux odeurs d"excrétion, et la pudeur concernant la flatulence. La quatrième sensibilité implique une attutude globale par rapport à l'élimination. Les femmes dans la population étudiée apparaissaient surtout sensibles à I'hygiène sanitaire tandis que les personnes gées montraient plus de pudeur quant à la flatulence. Sensibles aux odeurs excrếtoires s'avéraient être les individus souffrant de troubles de l'estomac et de l'abdomen et prenant des laxatifis. En somme, les problèmes pour aller à la selle semblaient être réservés aux femmes se plaignant de troubles physiques lors de la défécation ou prenant des laxatifs.

Le chapitre 5 présente une étude des sentiments et des besoins de vie privée lors de la défécation, à laquelle ont participé 92 malades hospitalisés, tous résidant dans des Services médicaux. Partant de l"analyse conceptuelle effectuée dans le chapitre 2, un instrument, échelle du type Likert, fut élaboré et validée pour mesurer les besoins d'intimité des patients lors de l'élimination. Cet instrument s'avérait suffisamment valide et fable pour mesurer les besoins globaux d'intimité ainsi que les quatre dimensions distinguées théoriquement, celles-ci étant: des besoins liés au contact sensoriel, à l'ingérence, à la solitude et au contrôle.

Les femmes dans la population étudiée étaient, généralement parlant, plus sensibles aussi bien a l'intimité excrétoire dans sa totalité qu'â la dimension de la solitude. La serxsibilité à la dimension d'ingérence concernait les personnes hautement qualifiées. Ceux dont l'éducation était plutôt peu élevée se montraient sensibles à la dimension du contact sensoriel. Sensibles aussi à la dimension d'ingérence s'avéraient être les participants qui, hospitalisés auparavant, avaient fait usage du bassin hygiénique au lit.

Une recherche concernant les préoccupations et les soucis que se font les malades hospitalisés par rapport à aller a la selle, est rapportée dans le chapitre 6. Cette étude a été monté originellement comme reproduction de la recherche de $\mathrm{Mme} L$. Wright sur la défécation et les malades hospitalisés ('Bowel function in hospital patients', 1974), el elargie ensuite par d'autres questions de recherche.

Une population fut composée de 160 malades hospitalisés, résidant dans des Services médicaux et chirurgicaux de deux hôpitaux universitaires et deux non-universitaires. Parmi ces participants des enquêtes furent menées, comprenant des questions ouvertes et structurées sur le fonctionnement et les résultats concrets de la defécation, à la maison comme à l'hôpital, ensuite sur les habitudes sanitaires et les expériences vécues lors de La défécation, utilisant soit les toilettes soit le bassin au lit. Enfin des données furent recueillies sur le traitement thérapeutique, la médication et l'usage des laxatifs, la nutrition el d"autres éléments de soins médicaux et infirmiers.

L'information recueillie montrait des préoccupations et des soucis par rapport à aller 
à la selle chez 41 pour cent des malades après I'hospitalisation. Les soucis apparaissaient, dans la population entière ainsi que chez ceux qui allaient aux toilettes, en relation avec une fixation sur le processus et les résultats concrets de la défécation, ainsi qu' avec un changement de la fréquence des selles. Chez les utilisateurs des bassins, les raisons les plus graves des préoccupations et des soucis s"avéraient être les sentiments de gêne et de pudeur, comme aussi la position instable sur le bassin.

Du point de vue de la prévention infirmière, la répartition des malades entrant à l'hôpital en ceux ayant et ceux $n$ "ayant pas de 'risques de selles problërnatiques' semble opportune. L'usage des laxatifs à la maison pourrait être un des indicateurs.

Quelques conclusions pratiques resultent du chapitre 6, notamment par rapport au diagnostic infirmiers lors de l'admission du patient dans le service. Cependant I'infirmière doit pouvoir disposer de l'information fiable quant à la santé et la maladie telles que vécues à la maison, si besoin aussi sur le modèle excrétoire normal ou affecté, et les habitudes le concernant. Dans le chapitre 7 il est étudiée la fiabilité de l'information donnée par les malades lors de leur admission dans le Service de soins.

Pour cette étude une population fut composée de 21 personnes figurant sur la liste d'attente d'un Service d'Orthopédie dans un hôpital général. Des données furent: recueillies d'abord ̀̀ la maison, notamment sur la santé et le bien-être des participants ainsi que sur le modèle excrétoire normal et les habitudes le concernant. Les mêmes données, donc par rapport à la situation à la maison, furent recueillies retrospectivement, quelques jours après l'admission à l'hôpital.

L'analyse comparative de ces données démontrait la fiabilité de l'information donnée par les malades sur l'état de leur santé à la maison. Particulièrement l'information globale concernant l'élimination à la maison s'avérait fiable. Pourtant certains aspects du modèle excrétoire normal étaient rapportés avec moins de fiabilité, ou même sans aucune fiabilité apparente. De cette modification de la fiablité, ancune hypothèse explicative n'a été identifiée. En conséquence la prévision du niveau de fiabilité de l'information sur l'élimination à la maison donnée par les patients reste incertaine.

Le chapitre 8 présente un résumé des conclusions pratiques, théoriques et méthodologiques, tirées des recherches rápportées. 

Bourke, J.G., Les riles scatologiques. Paris, Presses Universitaires de France, 1981 (Scalalogic Rites of all Nations. Washington, Lowdermilk, 1891 ; Voorwoord door $\mathrm{S}$. Freud: Leipzig. Ethnologischer Verlag, 1913.)

Bouwhuizen, M., Verpleeglkunde. Leiden. Spruyt, Van Mantgem \& De Does, 1972, In Goede Handen.

Brandeis, H. "The psychology of scatological privacy", in Joumal of Biological Psychology, 14, 1972,2, p. 30-35.

Bremer, J.J.C.B., De ziekenhuispatiënt; een hoofdstuk wir de medische psychologie. Nijmegen, Dekker \& Van de Vegt, 1972.

Bruggen, H. wan der, Leve de zieke; een arropologie van ziek zinh en verplegen. Lochem, De Tijdstroom, 1977 (19812) Verpleegkundige Studies 23.

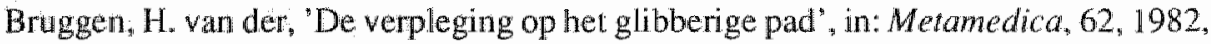
$7 / 8$, p. $245-263$.

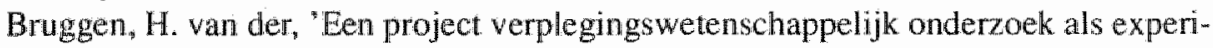
ment samenwerking WO-HBO', in: Verplegen in verschuivend perspectief, red. D. Bay e.a. Lochem, De Tijdstroom, 1984, p. 183-192.

Bruggen, H. wan der, Defecatieproblematiek bij ziekenhuispatienten; en replicatie-onderzoek. Maastricht, Rijksuniversiteit Limburg, 1985.

Bruggen, H. van der, Naar een antropologische verpleegkunde. Lochem, De Tijdstroom, 1987, Verpleegkundige Studies 61.

Bruggen, $H$. van der, 'De leefwereld wan de bejaarde (patiënt): verpleging en verzorging", in: J. van den Berg e.a. (red.), Leven in een instituut. Rotterdam, Stichting Bijen Nascholingscursussen KVV, 1987, KVV Cahiers 7, p. 35 - 55. (1987b)

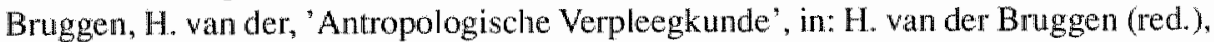
De delta van de Nederlandse verpleging. Lochem, De Tijdstroom, 1988, Verpleegkundige Studies 62, p. 99 - 117.

Burchfield, R.W., A supplement to the Oxford English Dictionary. Oxford, Clarendon, 1982.

Buytendijk, F.J.J., Prolegomena van een antropologische fysiologie. Utrecht, Het Spectrum, 1965, Aula 204.

Cabanès, A., Moeurs intimes du passé. Paris, Albin Michel, 1908.

Cunguithem, G., Le nornal et le pathologique. Paris, Presses Universitaires de France, $1966(1975,2)$.

Canguilhem, G. La connaissance de la vie. Paris, Librairie Philosophicue J. Vrin, 1975.

Clay, E.C., "Rehabilitative nursing", in: D. Mandelstam (red.), Incontinence and its management. London, 1980, p. 166-174.

Conelly, C.E., 'Replication in nursing research', in: International Joumal of Nursimg Studies, 23, 1986, 1, p. 71-77.

Connell, A.M., C. Hilton, G. Irrine e.a., "Variation of bowel habit in two population samples", in: British Medical Joumal, 1965, 2, p. 1095-1099.

Corbin, A., Le miasme et la jonquille. Paris, Aubier Montaigne, 1982.

Csergo, J. Liberté. egalité, properté. La morale de l'hygiène au XIXe siècle. Paris, Albin Michel, 1988.

Curtin, L., 'Privacy: belonging to oneself", in: Perspectives in Psychiatric Care 19. $1981,3 / 4$, p. $112-115$. 
Dassen, Th., De witscheiding als verpleegprobleem. Matricht, Rijksuniversiteit Limburg, 1984.

Devroede, G., 'Dietary fiber, bowel habits, and colonic function', in: The American Joumal of Clinical Nutrition, 1978, oct., p. 157-160.

De Vogiué, A. \& S. Grasset, S.O.S. Hopitaux. Paris, Gallimard, 1975.

Dirken, JI.P., Her meten van stress in imdustriële organisaties. Groningen, Rijksuniversiteit Groningen, 1967.

Drew, P. \& A. Wootton, Erving Goffman; Exploring the interaction onder. Cambridge. Polity Press, 1988.

Drossman, D.A., R.S. Sandler, D.C. McKee e.a., 'Bowel patterns amongs subjects not seeking health care”, in: Gastroenterology, 1982, 83, p. $529-534$.

DuGas, B.W. \& B.M. DuGas, Basisboek verpleegkunde: verplegen als integraal proces: Groningen, Wolters Noordhoff, 1985.

Elias, N., Het civilisatieproces. Utrecht, Het Spectrum, 1982, Aula 705 en 706 (Ueber den Prozess der Zivilisation. Soziogenetische und psychogenerische Untersuchmgen. Basel, Haus zum Falken, 1939).

Ellerbeck, J.P.W., De wereld van de zieke mens. Haarlem, De Toorts, 1961.

Engels, D., De uitscheidingsproblematiek op een psychogeriatrische afdeling. Maastricht, Rijksuniversiteit Limburg, 1985.

Englisch, P., Das skatologische Element in Literatur, Kunst und Volksleben. Stuttgart, Pïttmann, 1928.

Feldhaus, F.M., Ka-pi-fu; und andere verschome Dinge. Berlin, Friedenau, Privatdruck, 1921.

Festinger, L., A theory of cognitive dissonance. Evanston, Row, Peterson, 1957.

Foddy, W.H. \& W.R. Finighan, 'The concept of privacy from a symbolic interaction perspective', in: Jownal for the Theory of Social Behaviou, 10, 1980, 1, p. 1-1.7.

Forsyth, G.L., 'Exploration of empathy in nurse-client interaction', in: Advances in Nursing Science, 1, 1979, 1, p. $53-61$.

Freud, S., Drei Abhardlungen zur Sexualtheorie. 1905.

Frexinos, J., 'La vie quotidienne du constipé', in: Le Quotidien du Médecin, 16 sept. 1982, Suppl. 15.

Friedlander, W.I." "The basis of privacy and autonomy in medical practice", in: Soc. Sci. Med., 16, 1982, p. 1709 - 1782.

Gaignebet, Cl., Le camaval. Paris, Payot, 1979.

Gaignebet, C]., Le folklone obscene des enfants. Paris, Maisonneuve \& Larose, 1980.

Gill, K., "De defaecatie van de mens", in Huisarts en Wetenschap, 1979. 22, p. 186191.

Gleichmann, P.J., "Städte reinigen und geruchslos machen", in: H. Sturm (red.), Aesthetik wo Umwelt. Tübingen, Narr, 1979a, p. 99-132.

Gleichmann, P.J., 'Die Verhäuslichung körperlicher Verrichtungen' "in: P.R. Gleichmann, J. Goudsblom \& H. Korte (red.), Materialien zu Norbert Elias' Zivilisationstheorie. Frankfurt, Suhrkamp, 1979b, p. $254-278$.

Goffman, E. Interaction ritual: Essays onface-ro-face behavior: New York, Doubleday Anchor, 1967. 
Goffman, E., Relations in public, Michostudies of the public order. Harmondsworth, Penguin Books, 1971.

Graf, $\mathrm{F}$. de, Bescherming van persoonlijkheid, privé-leven en persoonsgegevens. Aphen aan den Rijn, Tjeenk Willink, 1977.

Gregg, D.E., 'Anxiety - A factor in nursing care', in: American Joumal of Nursing, 52, 1952, Nov . p. $1363-1365$.

Gregg, D.E., "Reassurance", in: American Joumal of Nursing, 55, 1955, Febr., p. 171 -174 .

Groddeck, 'La constipation comme résistance type' ('Verstopfung als Typus des Widerstands" ${ }^{\prime}$, in: Groddeck, G., La maladie, l'art et le symbole. Paris, Gallimard, 1926.

Gruschke, A.M., Het beoordelen van het zelfzorgvermogen wan psychiatrische patienten door de persoonlijke begeleider en andere personeelsleden. Maastricht, Rijksuniversiteit Limburg, 1990.

Grypdonck, M., "Van continuiteit van zorg naar zorg voor contimuiteit", in: Tijdschrift woor Ziekenverpleging, 43, 1989, 15, p. 487 - 492.

Hamer, B.Chr. \& J.H. Haverkate, Leerboek bij het verplegen van geestes-en zenuwzieken. Amsterdam, Van Mantgem \& De Does, 1950(8).

Hamer, B.Chr. \& F.J. Tolsma, Algemeen leerboek voor het verplegen van geestes-en zenuwzieken. Leiden, Spruyt, Van Mantgem \& De Does, 1964(11).

Heers, J., Fetes des fous et camavals. Paris, Fayard, 1983.

Henderson, V. \& G. Nite, Principles and practice of nursing. New York, Macmillan, 1975.

Hilderink, H.G.M., 'Gebruik wan priwacyreglementen: erwaringen in het AZVU', in: Privacyreglementen in de gezondheidszorg. Alphen aan den Rijn, Samsom, 1986.

Hofland, H.J.A..' 'Stront", in: Nieuw Wereld Tijdschrift, 3, 1986, 4, p. 77-80.

Holvast, J., Op weg naar een risicoloze maatschappij? De wrijheid yan de mens in de informatie-samenleving. Leiden, Rijksuniversiteit Leiden, 1986.

Holvast, J., H. van Dijk, G.J. Schep, Privacy doorgelicht. 's-Gravenhage, Stichting Wetenschappelijk Onderzoek Konsumentenaangelegenheden, Instituut voor Consumentenonderzoek, \& Stichting Waakzaamheid Persoonsregistratie, 1989.

Hunt, J.M. \& D.J. Marks-Maran, Het verpleegkundig dossier; het verpleegkundig proces in de praktijk. Lochem, De Tijdstroom, 1982 (Nursing care plans; The mursing process at work. Aylesbury, H M $+\mathrm{M}, 1980$ ).

Hunter, M., R.M. Grinnell jir., R. Blanchard, 'A test of a shorter privacy preference scale', in: The Jownal of Psychology, 1978, 98, p. $207-210$.

Ittelson, W. H. Proshansky, L. Rivin \& G. Winkel, An intraduction to environmental psychology. New York, Holt, Rinehart \& Winston, 1974.

Johnson, C., "Privacy as personal control', in: D. Carson (ed.), Man-environment interactions: evaluations and applications, II. Stroudsburg. Dowden, Hutchinson \& Ross, 1974, hfdstk 6, p. $83-100$.

Johnson, D.E., "The behavioral system model for nursing", in: J.P. Riehl \& Callista Roy, Conceptual models for nursing practice. New York, Appleton, Century, Crofts, $1980^{2}$, p. $207-216$.

Jones, I.S.C., 'An analysis of bowel habit and its significance in the diagnosis of 
carcinoma of the colon", in: The American Joumal of Proctology, 1976, june, p. 45 -56 .

Joosten, J., \& M.J. Drop, 'De betrouwbaarheid en vergelijkbarheid van drie versies van de VOEG', in: Gezondheid en Samenleving, 8, 1987, 4, p. 251 - 265.

Jourard, S., Self-disclosure: an experimental analysis of the transparent self: New York, Wiley, 1971.

Juchli, L., Leerboek verpleegkunde 1. Amsterdam, Elsevier, 1980.

Kalter, L., Betrowwbaarheid en validiteit van de ASA-schaal bij mering van zelfzorgvermogen van revalidanten. Maastricht, Rijksuniversiteit Limburg, 1987.

Kelvin, P., "A sociall-psychological examination of privacy', in: Brit. Joum soc, chin. Psychology, 1973, 12, p. 248-261.

Kerlinger, F.N., Foundations of behavioral research. New York, Holt, Rinehart \& Winston, 19732.

Kleber, R.J. \& D. Brom, 'Ingrijpende rolveranderingen en hun gevolgen", in: E. van de Vlient, A.Ph Visser, P.G.J. Zwaga, J.A.M. Winnubst en E.J.H. ter Heide (red.), Rolspanningen. Boom, Meppel, 1983.

Klein, E, A comprehensive etymological dictionary of the English language. Amsterdam, EIsevier, 1971.

Kline, L.M. \& P.A. Bell, 'Privacy preference and interpersonal distancy', in: Psychological Reports, 1983, 53, p. 1214.

Klop, R., Angstbeleving van cardiologische patiënten en de herkenning hiervan door verpleegkundigen. Maastricht, Rijksuniversiteit Limburg, 1984.

Knippenberg, A. van, F. Siero, Multivariate analyse; beknopte inleiding en toepassing. Deventer, Van Loghum Slaterus, 1980.

Kooij, C. van der, Defaecatiepatroon als verpleegprobleem. Utrecht, Instituut voor Verplegings-Wetenschap, 1987.

Kramer, F., Psychiatrische verpleegkunde. Lochem, De Tijdstroom, 1968.

Kuitenbrouwer, F., "Privacy", in: Grote Winkler Prins Encyclopedie. Amsterdam, Elsevier, 19828,18 , p. 393-394.

Laporte, D., Histoire de la merde. Paris, Bourgois, 1978.

Leriche, $\mathrm{R}$., 'Introduction générale; De la santé à la maladie; La douleur dans la maladie; Où va le médecine?' Encyclopédie Française, VI, 1936, 6.16-1.

Lieburg, M.J. van (Inl.), Over ziekenerpleging. Alphen aan den Rijn, Stafleu, 1980, Libruje der Geneeskonst 4.

Ligthart, L., Encopresis, een exploratief onderzoek in en rond de huisartspraktijk. Leiden, Rijksuniversiteit Leiden, 1988. Proefschrift.

Little, D.E. \& D.L. Camevali, Nursing care planning. Philadelphid, Lippincott, 1969.

Loor-Netjes. W. \& F. Woudenberg, 'Deffaecatieproblematiek na opname in her ziekenhuis", Leusden-C., Hogere School voor Gezondheidszorg, 1984.

Macdonald, L. \& P. Freeling, 'Bowels: beliefs and behaviour", in: Family Practice, 3. 1986,2, p. $80-84$.

Malinsky, V.M. Explorations on Martha Rogers" Science of Unitary Human Beings. New York, Appleton, Century, Crofts, 1986.

Manning, A.P. J.B. Wyman, K.W. Heaton, 'How trustworthy are bowel histories? Comparison of recalled and recorded information", in: British Medical Joumal, 1976. 
jul. $24, \mathrm{p} .213-214$.

Marriner, A., The minsing process. St. Louis, Mosby, 1975.

Marshall, N." Environmental componients of orientations towand privacy", in: J. Archea \& C. Eastman (eds.), EDRA 2: Proceedings of the 2 nd anmual Environimental Design Research Association conference. Pitsisburgh, $\mathrm{Pa}, 1970 \mathrm{~A}$.

Marshall. N., 'Personality correlations of orientation toward privacy", in: J. Archea \& C. Eastman (eds.), EDRA 2: Procedings of the 2nd annual Environmental Design Research Association conference. Pittsburgh, $\mathrm{Pa}, 1970 \mathrm{~B}$.

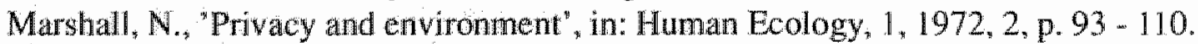

Marshall, N., 'Dimensions of privacypreferences', in: Multivariate Behavior, 9, 1974 , p. 255-271.

Mauchamp, $\mathrm{G}_{*}$, Soins infirmiers aux personnes constipées. Lyon, Université de Lyon II, E.I.E.I.S., 1983.

McClemens, J.M., "Privacy and the individual", in: National Hospiral and Healh Care, 1,1976, p. $7-10$.

Meijer, G.H., Handboek voor pleegzusters en ziekenoppassers. Groningen, Van Bolhuis Hoitsema, 1848.

Moolen, J.C.W. van der \& H.J. Quanjer, Verpleegkunde; basis-verpleginglpreklinische periode. Lochem, De Tijdstroom, 1967(4).

Muir Gray, J.A., 'Incontinence in the community", in: D. Mandelstam (red.), Incontinence and its management. London, 1980 , p. 110 - 121.

Munnichs, J.M.A. (red.), Toiletgang bij ouderen. Lochem, De Tijdstroom, 1984, Moderne Gerontologie 1.

Nightingale, F., Over ziekenverpleging: wat men, om de herstelling fe bevorderen, te doen en te vermijden heefr. Amsterdam, Schadd, 1862 (Notes on nursing: what it is and what it is not, 1859, vert. A.D. Busken Huer, 1862).

Nijssen, C., Onderzoek naar het feitelijke en wenselijke hulpaambod in een verzorgingsrehwis. Maastricht, Rijksuniversiteit Limburg, 1987.

Norris, C.M., Concept clarification in nursing. Rockville, Aspen, 1982.

Onions, C.T. (ed.), The Oxford Dictionary of English Etymology. Oxford, Clarendon, 1978.

Oomkes, F.R., Communicarieleer. Meppel, Boom, 1986.

Palmer, R., Awch das W.C. hat seine Geschichte. München, Pfriemer, 1977.

Pardailhé. Galabrun. A., La nassance de l'intime. Paris, PUF, 1988.

Parent, W., Sanitair, een historisch overzicht. Dellt, Delftse Universitaire Pers, 1987.

Park, R.E. \& E.W. Burgess, Imroduction to the science of sociology. New York. Greenwood, 1924.

Pedersen, D.M., 'Dimensions of privacy", in: Perceptual and motor skills, 1979, 48, p. $1291-1297$.

Pedersen, D.M., 'Cross-validation of privacy factors', in: Perceptual and motor skills, 1982,55, p. $57-58$.

Peet, R.A.M. van der, Verpleegkunde 1: de lichamelijkheid van de mens. Lochem, De Tijdstroom, 1984.

Peplau, H., 'Loneliness", in: American Journal of Nursing, 55, 1955, Dec., p. 1476. Philipsen, H., \& H. van der Bruggen, 'Verplegingswetenschap in Maastricht', in: H. 
van der Bruggen (red.), De delta van de Nederlandse verpleging. Lochem, De Tijdstroom, 19892, p. $181-194$.

Pleij, H., Her gilde van de Blawwe Schuit, Lineratww, volksfeest en burgermaraal in de late middeleewen. Amsterdam, Meulenhoff, 1979.

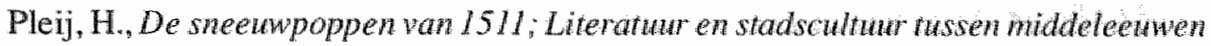
en moderne tijd. Amsterdam, Meulenhoff, 1988

Popken, J., Intimiteiten; Een culuursociologisch essay. Kampen, Kok Agora, 1988.

Poslavsky, A., Voordrachen over medische psychologie. Utrecht, Bijleveld, 1956.

Proshansky, H., W. Ittelson \& L. Rivlin, 'Freedom of choice and behavior in a physical setting', in: H. Proshansky, W. Ittelson \& L. Rivlin (eds.), Environmental psychology: man and his physical setting. New York, Holt, 1970.

Rawnsley, M.M., 'The concept of privacy', in: Advances in Nursing Science, 2, 1980 , 1 . p. 25-31.

Roding, J., Schoon en net; hygiëne in woning en stad. "S-Gravenhage, Staatsuitgeverij, 1986.

Roy, Callista, Introduction to nursing; An adaptation model. Englewood Cliffs, Prentice-Hall, 19842.

Rubin, R., 'Body image and self-esteem', in: V.A. Christopherson e.a. (red.), Rehabilitation nursing. New York, 1974, p. $49-55$.

Sandler, R.S., "Bowel habits in young adults not seeking health care", in: Digestive Diseases and Sciences, 32, 1987, 8, p. $841-845$.

Schenk, J., "Urban form and the control of private life', in: Architecture in Australia, 61,1972, p. $173-177$.

Schiltmans, M.M.C., Het thwisfunctioneren van reumatoüde arthritis patiënten. Maastricht, Rijksuniversiteit Limburg, 1987.

Schrik-van Bodegom, M., 'Privacy ten aanzien van medische en psychologische gegevens', in: Tijdschrift voor Ziekenverpleging, 33, 1980, 19, p. 901-912.

Schulkens, Y., De herkenning van angstbeleving van de patiët door de verpleegkundige en de factoren die hierbij een rol spelen. Maastricht, Rijksuniversiteit Limburg, 1987.

Schuster, E.A., 'Privacy, the patient and hospitalization', in: Social Science and. Medicine, 10, 1976, 5, p. 245-248.

Schwartz, B., "The social psychology of privacy', in: American Journal of Sociology, 1968,73, p. $741-752$.

Seligman, $\mathrm{C}$., "What is a door? Notes towards a semiotic guide to design", in: Semiotica. $38.1982,1 / 2$.

Shepherd, A., e.a., "The role of the nurse", in: D. Mandelstam (red.). Incontinence and its management. London, 1980, p. $135-155$.

Sills, D.L., International Encyclopedia of the social sciences. New York, Macmillan \&. Free Press, 1968.

Silva, M.C. \& D. Rothbart, "An analysis af changing trends in philosophies of science on nursing theory development and testing, in: Advances in Narsing Science. January, 1984, p. 1 - 13.

Smaling, A., "Muinchhausen-objectiviteit; Een nieuwe conceptie van objectiviteit als methodologische norm', in: Psychologie en Maarschappij, 17, 1988, 44, p. 272 - 288. 
\$mith, D.E \& R.M. Swanson, 'Privaey and corrections: A social learning approach", in: Criminal Justice and Behovior, 1979, 6, p. $339-357$.

Spijker, T., Mooi en beschaafd verplegen. Lochem, De Tijdstroom, 1979, Verpleegkun. dige Studies 26.

Stignen, I., Privacygevoeligheid van ziekenhuispatiènten te a anzien yan de ontlasting. Maastricht, Rijksuniversiteit Limburg, 1988.

Stillman, M.J., "Ternitoriality and personal space" in: American Journal of Nursing. okt. 1978. Vert. M. Ederween-Lucas, 'Territorialiteit en persoonlijke ruimte', in: Tijdschrift voor Ziekenverpleging, 33, 1980, 3, p. 96-100.

Strong, P.M. The ceremonial order of the clinic. London, Routledge \& Kegan Paul, 1979.

Strong, P.M., 'Minor courtesis and macro structures', in: P. Drew \& A Wootton, $E$. Goffman; Explaring the interaction order. Oxford, Polity Press, 1988, p. 228-249.

Swalan, A. de, De mens is de mens een zorg; opstellen 1971 - 1981. Amsterdam, Meulenhoff, 19844 (19821).

Swaan, A. de, Zorg en de staat. Amsterdam, Bakker, 1989 (In care of the state, Health care, education and welfare in Europe and the USA in the Modern Era. 1988).

Tenon, M., Mémoives sur les hópitaux de Paris. Parijs, 1788.

Tollenbeek, J., De toga van Fruim. Denken over geschiedenis in Nederland sinds 1860. Amsterdam, Wereldbibliotheek, 1990.

Van Dale Groot Woordenboek der Nederlandse Taal. Utrecht, Van Dale Lexicografie, $1984(11)$.

Vigarello, G., Le propre et le sale; L'hygiène depuis le Moyen Age. Paris, Seuil, 1985.

Visser, A.Ph., De beleving van het verbliff in het algemene ziekenhuis. Tevredenheid. kenmis en emotionele toestand van ziekenhuispatiënten: meting "inhoud en determimanten. Assen, Van Gorcum, 1984.

Waard, J.M.D. de, 'Het deeladvies Privacy van de Centrale Raad', in: Tijdschrift voor Ziekenverpleging, 36, 1983, 5, p. 126-130.

Walden, T.A., P.A. Nelson, D.E. Smith, 'Crowding, privacy and coping', in. Environment and Behawiour, 13, 1981, 2, p. $205-224$.

Walker, L.O. \& K.C. Avant, Strategies for theory construction in nursing. Norwalk, Appletion \& Lange, 1988.

Westin, A.F., Privacy and freedom. New York, Alheneum, 1967.

Whiting, F.S., 'Needs, values and perceptions and the nurse-patient relationship', in: Journal for Clin. Psychol., 1959, 15, p. 146.

Wijk, H.J. van, Het iritable bowel syndroom; een multifactoriele benadering. Utrecht, Rijksuniwersiteit Utrecht, 1988.

Williamson, R.C., P.C. Swingle \& S.S. Stansfeld Sargent, Social psychology. Illinois, Jolunson, 1982.

Wilmoth, G., The perception of privacy: a multidimensional scaling analysis. Florida, University of Florida, 1980.

Wolters, W., Kinderen met encopresis, in psycho-somatische benadering. Utrecht, Rijksumiversiteit Utrecht, 1974.

Wright, L., Clean and decent; the fascinating history of the bathroom \& the water closet. London, Routledge \& Kegan Paul, 1966. 
Wright, L., Bowel function in hospital patients. London, Royal College of nursing and National Council of Nurses of the United Kingdom, 1974, The Study of Nursing Care. Yura, H., \& M.B. Walsh, The nursing process. Assessing, planning, implementation, evaluation. New York, Appleton, Century, Crofts, 19783.

Zon, H. van, Een zeer onfrisse geschiedenis. Studies over niet-industriële veromireiniging in Nederland, 1850-1920. 's-Gravenhage, Ministerie varn Volkshuisvesting. Ruimtelijke ordening en Milieubeheer, 1986. 
Bijlagen 
Bijlage 3.1 Dagboek ter registratie van het normale defecatiepatroon.

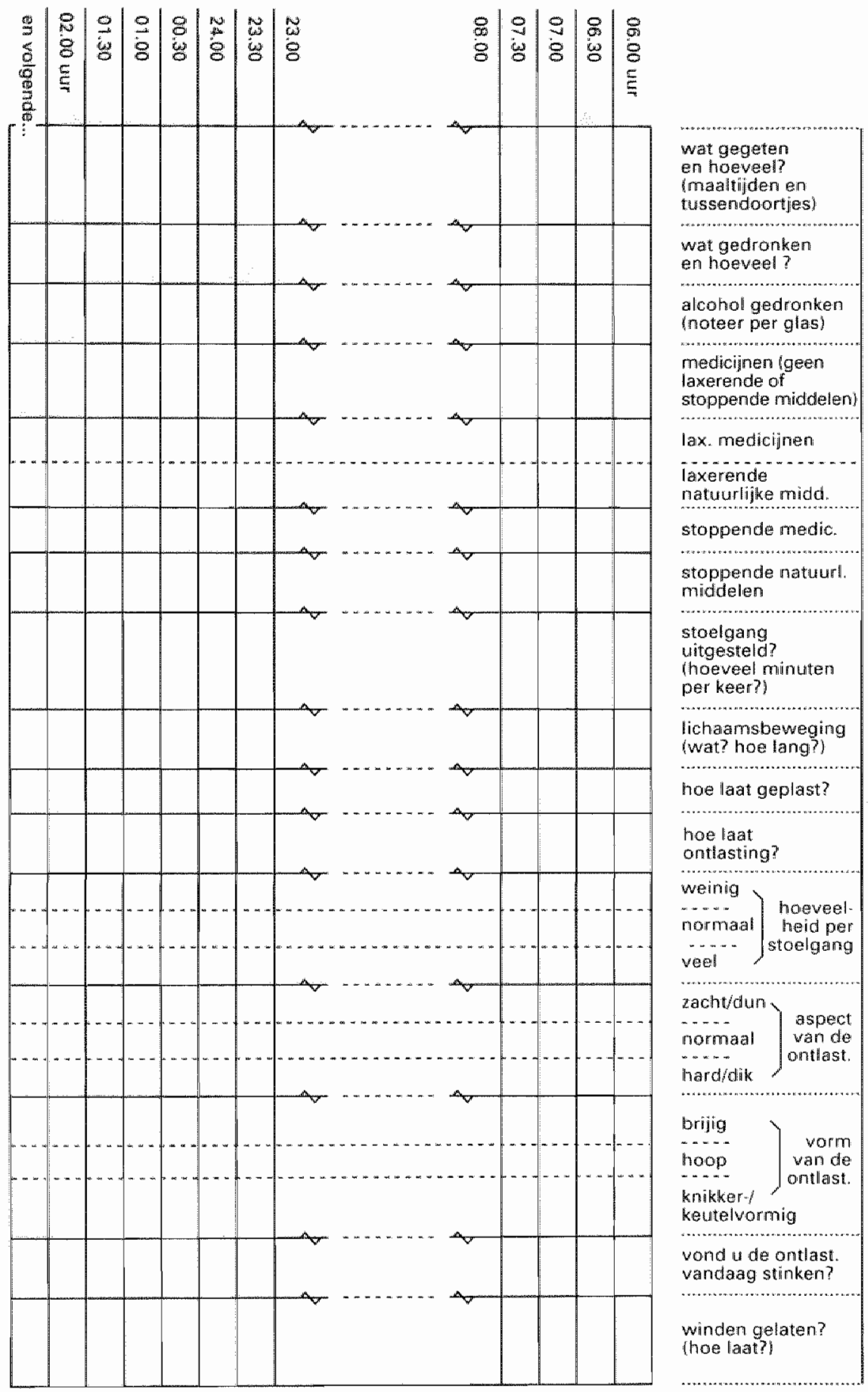


Bijlage 3.2 Factorladingen op twee factoren, na varimaxtrotatie, voor de hele populatie alsook voor de vier subgroepen.

Factor 1

Factor 2

Ontlastingen var de hele populatio $(n=1468)$

- Vorm

- Hoeveelheid

- Tijdstip

- Duur

- Uitstel

Percentage verklaarde wariantie: 49

Ontfastingen jongere mannen $(n=326)$

- Vorm

- Hoeveelheid

- Uitstel

- Duvir

- Tijdstip

Percentage verklaarde variantie: 48

Ontlastingen oudere mannen $(n=22.5)$

- Tijdstip

- Hoeveelheid

- Vitstel

- Duur

- Vorm

Percentage verklaarde variantie: 52

Ontlastingen jongere vrouwen $(n=582)$

- Vorm

- Hoeveelheid

- Tijdstip

- Duur

- Uitstel

Percentage verklaarde variantie: 48

Ontlastingen oudere vrouwen $(n=335)$

- Vorm

- Tijdstip

- Dusar

- Uitstel

- Hoeveetheid

Percentage verklaarde variantie: 47
$.68 \quad-.25$

$-66$

63

.01

$-.03$ 
Billage 3.3 Pearsons correlatiecoëficiënten, naar vier subgroepen: stoelganggerelateerde datamatrix $(n=1468)$.

Totale aantal

Tolale arintal

Hoeveetheid
Vorm

$\begin{array}{cccc}1 & -.06 & 1 & .04 \\ 2 & .06 & 2 & .21 \\ 3 & -.20^{* * * *} & 3 & .07 \\ 4 & .09^{* *} & 4 & -.01 \\ 5 & -.09^{* * *} & 5 & .02\end{array}$

$1-.09$

$2-.04$

$3-.22^{* * * *}$

$4-13^{* *}$

$5-16 \%$

Vorm

Tildstip

Duvir

Uitstel

1 mannen < 40 jäar

2 mannen $>40$ jaar

3 vrouwen < 40 jaar

4 yrouwen > 40 jaar

5 total

* $p \leq .05$

** ps. 01

$* *$ p $\leq .001$ 


\section{Tijdstip}

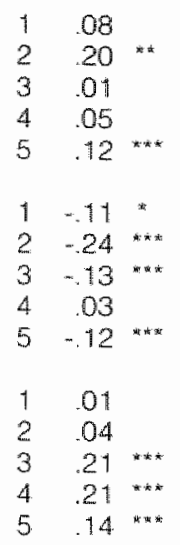

Duter

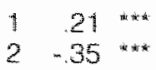

$3-.12 * *$

$\begin{array}{ll}4 & -.01\end{array}$

$5.16^{* * \times}$

$1-.15^{* *}$

$2.15^{* *}$

3.06

$4 . .06$

5. -.01

$1 \quad-.01$

$2-.09$

$3-.02$

4.05

$5 \quad-.09$
Uitstel

$$
\begin{array}{ll}
1 & -.10 \\
2 & -.03 \\
3 & -.07 \\
4 & -.07 \\
5 & -.05 \\
& * \\
1 & .02 \\
2 & .03 \\
3 & .06 \\
4 & .03 \\
5 & .03 \\
1 & -.04 \\
2 & -.07 \\
3 & -.05 \\
4 & -.02 \\
5 & -.03
\end{array}
$$

$\begin{array}{ll}1 & .06 \\ 2 & .01 \\ 3 & -.02 \\ 4 & -.02 \\ 5 & .04 \\ 1 & .17 \\ 2 & .29 \\ 3 & -.01 \\ 4 & .07 \\ 5 & .11\end{array}$




\section{Bijlage Hoofdstuk 4}

\section{Biflage 4.1 Pearsons correlatiematrix van de relevante variabelen}

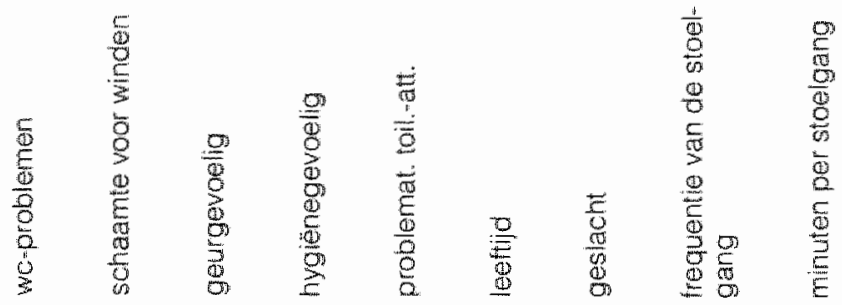

wo-problemen

schaamie voor winden $\quad .55^{3}$

geurgevoelig

$.60^{3} \quad .02$

hygiënegevoelig

$.73^{3} \quad .25^{2} \quad .31^{2}$

problematische

toilet attitude

$\begin{array}{llll}.59^{3} & .09 & .12 & .24^{1}\end{array}$

leeltijo

$.13 \quad \quad .22^{1} \quad-.10 \quad .10 \quad .10$

geslacht

$\begin{array}{llllll}-.32^{3} & -.14 & -.15 & -.24^{1} & -.26^{2} & .02\end{array}$

Irequentie

van de stoeligang

$\begin{array}{ccccccc}-.08 & -.00 & -.08 & -.12 & -.00 & .03 & .00\end{array}$

minuten per stoelgang

$\begin{array}{llllllll}-.04 & -.11 & .19^{1} & .13 & -.30^{2} & -.22^{2} & .18^{1} & -.21^{1}\end{array}$

vindt ontl. vaak stinken

$\begin{array}{lllllllll}-.15 & -.12 & -.05 & -.07 & -.13 & -.06 & .15 & .44^{3} & -.17^{1}\end{array}$

is zelf vaak winderig

$\begin{array}{lllllllll}-.18^{1} & -.05 & .01 & -.13 & -.28^{2} & .06 & .15 & -.00 & .15\end{array}$

stelt stoelgang vaak uit

$\begin{array}{lllllllll}-.08 & -.08 & -.06 & -.05 & -.11 & -.46^{3} & -.17^{1} & .05 & .22^{1}\end{array}$

leest op tollet

$\begin{array}{lllllllll}-.17^{1} & -.21^{1} & 10 & -.10 & -.21^{1} & -.33^{3} & .02 & .18^{1} & .19^{1}\end{array}$

aangekleed roilet

$\begin{array}{lllllllll}-.13 & -.19^{1} & -.02 & -.13 & .03 & -.34^{3} & -.13 & -.13 & .04\end{array}$

klachten maag/buik

$\begin{array}{lllllllll}.18^{1} & -.00 & .19^{11} & .07 & .21^{1} & -.01 & -.18^{1} & .10 & -.06\end{array}$

vindt zichzelf te dik

11

$16-07$

$\begin{array}{lllll}19^{1} & -.02 & .04 & -.14 & -.04\end{array}$

lichamelijk ongemak

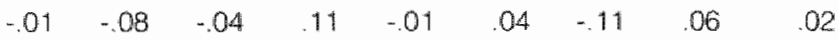

laxerende middelen

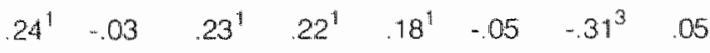

$-01$

$1=p \leq 0.05$

$2=p \leq 0.01$

$3=p \leq 0.001$ 


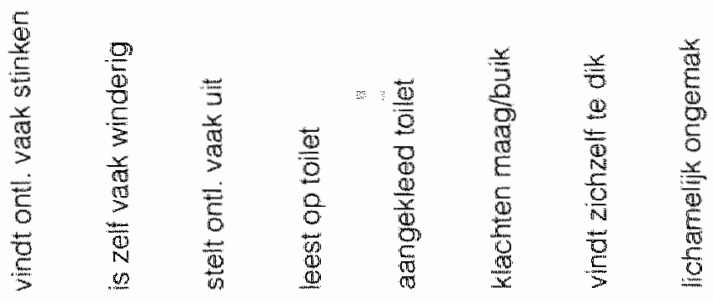

$-.20^{1}$

$-.03 \quad-.05$

$.06 \quad .05 \quad 27^{2}$

$\begin{array}{llll}.03 & -.08 & .09 & .08\end{array}$

$\begin{array}{lllll}-.06 & -.07 & -.04 & .10 & 10\end{array}$

$\begin{array}{llllll}-.23^{1} & -.04 & .03 & .01 & -.04 & -.20^{1}\end{array}$

$\begin{array}{lllllll}-.14 & -.14 & .28^{2} & .19^{1} & .04 & .20^{1} & .10\end{array}$

$\begin{array}{llllllll}.14 & -.15 & .17^{1} & -.15 & -.08 & -.02 & -.02 & 11\end{array}$ 
Billage 5.1 ltems niet opgenomen in de data-analyse vanwege eenstemmigheid van de antwoorden: $\geq 80 \%$

Var. Uitspraak

Percentage

Col 1: 'vanzelfsprekendheid van gebruiken en gewoonten

ler voorkoming van ziniuglijke inbreuk op de privacy:

21 Vindt vanzelisprekend dat bed (met po) of po-stoel wordt afgeschermo

26 Mindt wanzelfsprekend dat, wanneer men op de po(-stoel) gaat, hei

bezoek de kamer werlal.

28 Vindt vanzelfsprekend dal, wanneer men op de po(-stoel) gaat, verpleegkundigen niet komen storen mel activiteiten die niel rechisir reeks met de stoelgang te maken hebben

29 Vindt vanzelfsprekend dat, wanneer men op de po(-stoel) gaat en men alleen kan zilten, verpleegkundigen niet komen helpen ondersleunen

30 Vind vanzelisprekend dat wanneer men op de po(-stoel) gaat , verpleegkundigen alleen op verzoek komen helpen

31 Vindt wanzelfsprekend dal, wanneer men op de po(-stoel) gaat, eke willekeurige verpleegkundige kan komen helpen

33 Vindt vanzelfsprekend dat verpleegkundigen die komen helpen na stoelgang, niets laten merken t.a. v. de geur

36 Vindt, voorzover zelfredzaam, na de stoelgang door verpleegkundige geholpen worden niet vanzelfsprekend

37 Vind vanzelfsprekend dat, als beddegoed bevuild is, dit onopvallend wordt verschoond en weggebracht

38 Vindt vanzelfsprekend dat po, na gebruik, afgedekt wordt weggebracht

«3 Vindt vanzelfsprekend dat de ondersteunende verpleegkundlige niets van ongeduld laat blijker:

47 Vindt tonen van ontasting i.v.m. medische diagnose vanzellsprekend

51 Vind miet vanzelfsprekend dat kamergenoten hun bezoek vertellen over midin stoelgang

54 Vindt vanzelfsprekend in het ziekenhuis evenveel tijd voor de stoelgang te nemen als thuis

Cela 'vanzelisprekendheid van gebruiken en gewoonten ter voorkoming van hinderlike bemoeiens':

9 Vindt het vanzelfsprekend dat gevraagd wordt naar problemen met de ontlasting

10 Vindt vanzellsprekend dat wordt gevraagd naar thuisgebruik wan laxeermiddelen

12 Vindt vanzelfsprekend dat wordt gewaagd hoe vaak per week ontlasting 
17 Vindi vanzelfsprekend dat dagelijks wordi gevraagd of men ontiasting heeft gehad

Cel 3: "belangrikheid van materieel-organisatorische maalregelen tegen zintuiglijke inbreuk op privacy:

64 Vindt belangrijk zich op de po(-stoel) te kinnen bedekken (voor zower nadig)

83 Vindt belangrijk inname van laxantia te kumen uitstellen tot na het bezoek

Cel 4: belangrijkheid van materieel-organisatorische maatregelen tegen hinderlijke bemoeienis:

62. Vindt belangrik zelf te kunnen beslissen of men voor de stoelgang naar toilet mag 


\section{Bijlage bij hoofdstuk 5}

\section{Bijlage 5.1 Items niet opgenomen in de data-analyse vanwege eenstemmigheid van}

de antwoorden: $\geq 80 \%$.

Var.

Witspraak

Percentage

Cel 1. "wanzeltsprekendheid van gebuiken en gewoonten

ter voorkoming van zintuiglike inbreuk op de privacy:

21 Vindt vanzelfsprekend dat bed (met po) of po-stoel wordt afgeschermo

26 Vindt vanzelfsprekend dat, wanneer men op de pot-stoel) gaat, het bezoek de kamer verlaat

20 Vindt vanzelfsprekend dat, wanneer men op de po(-stoel) gaat, verpleegkundigen niet komen storen met activiteiten die niet rechtstreeks met de stoelgang te maken hebben

29 Vindt vanzelfsprekend dat, warneer men op de po(-stoell) gaat en men alleen kan zitten, verpleegkundigen nie: komen heipen ondersteunen

30 Vindt wanzelfsprekend dat, wanneer men op de po(-stoel) gaat, verpleegkundigen alleen op verzoek komen helpen

31 Vindt wanzelsprekend dat, wanneer men op de po(-stoel) gaat, elke willekeurige verpleegkundige kan komen helpen

33. Vindt vanzelfsprekend dat verpleegkundigen die komen helpen na stoelgang, niets laten merken l.a.w. de geur

36 Vindt, woorzover zelfredzaam, na de stoelgang door verpleegkundige geholpen worden niet vanzelfsprekend

37 Vindt van"elfsprekend dat "als beddegoed bevild is "dit onopvallend wordt verschoond en weggebracht

38. Vindt vanzelfsprekend dat po, na gebruik, afgedekt wordt weggebracht

43 Vind vanzelfsprekend dal de ondersleunende verpleegkundige niets van ongeduld laat blijken

47 Vindt tonen van ontlasting i.v.m. medische diagnose wanzelfsprekend

51 Vind miet vanzelfsprekend dat kamergenoten hun bezoek vertellen over inijn stoelgang

54 Vindt vanzelfsprekend in het ziekenhuis evenveel tijd voor de stoelgang te nemen als thuis

Cel 2: "wanzelsprekendheid van gebruiken en gewoonten ter voorkoming van hinderlijke bemoeienis':

9 Vindt hel wanzelfsprekend dat gevraagd wordt naar problemen met de ontlasting 
17 Vind wanzelisprekend daf dagelijks wordt gewraagd of men onttasting heeft gehad

Cel 3: "belangrijkheid van materieef-organisatorische maatregelen tegen zintuiglike inbreuk op privacy':

64 Vindt belangrijk zich op de po(-stoel) te kumnen bedekken (voor zover nodig)

83 Vindl belangrijk inname van laxanila te kunnen uitstellen tot na het bezoek

Cel 4: 'belangrijkheid van materieel-organisatorische maatregelen tegen hinderlijke bemoeienis": 
. 


\section{Dankwoord}

De dagelijkse althans geregelde stoelgang is niet een alledaags onderwerp van promotie-onderzoek. De stoelgang van de patiènt heeft wel de professionele aandacht van de verplegenden, maar wetenschappelijke belangstelling werd tot nu toe zelden getoond. Voor verplegingswetenschap, die zich nog grotendeels moet bewijzen, lijkt met de keuze van dit onderwerp weinig eer te kunnen worden ingelegd. Enkele collega's vanuit de beroepsgroep echter, alsook uit het wetenschappelijk onderwijs, hebben mij zeer gestimuleerd de stoelgang als onderwerp van promotie-onderzoek te kiezen.

In het begin al, toen ik als docent nog in het hoger beroepsonderwijs stoelgangproblemen van patiënten wilde maken tot onderwerp van nursing research, ondervond ik de enthousiaste instemming en medewerking van mw. C.A.M. Verbeek, destijds directeur van de Hogere School voor Gezondheidszorg te Leusden.

Een van de eersten die mij stimuleerden tot wetenschappelijk onderzoek van stoelgangproblemen van gezonden en zieken, was prof. dr. L.J. Menges. Door zijn niet aflatencle belangstelling-op-afstand heb ik mij zeer gesteund gevoeld.

Veel dank ben ik verschuldigd aan mijn promotoren. Prof. dr. H. Philipsen begeleidde het promotie-onderzoek met enerzijds een brede belangstelling voor en visie op het onderzoeksonderwerp, anderzijds een voorkeur voor diepgang en voor precisie ten aanzien van het detail. Vasthoudendheid bleek één van de wenselijke kwaliteiten van de onderzoeker.

Met prof. dr. J.J.C.B. Bremer, eveneens promotor, werd in vele rijke gesprekken gekeken naar de theoretische alsook de praktisch-verpleegkundige implicaties van de deelonderzoeken. Veel tijd en moeite werd, niet tevergeefs, besteed aan de exacte formulering van de bevindingen.

Nodige steun ondervond ik van dr. R. Halfens die, als copromotor, watkte over methodologische en technische aspecten van opzet, uitvoering en verslaglegging van de diverse onderzoeken.

Veel dank ben ik verschulligd aan degenen die in het kader van de doctorallopleiding verplegingswetenschap in deelonderzoeken bijdroegen aan verheldering van de stoelgangproblemen van gezonden en zieken. Het deelonderzoek omtrent privacygevoeligheid kwam tot stand met de hulp van Ilse Stijnen. In het dagboekonderzoek participeerden Paul van Ruiten, Rob Schreurs en Dianne Engels. Deze laatste was, als student-assistente, een onmisbare steun bij Jiteratuurresearch en documentatie, alsook vooral bij het replicatie-onderzoek. Door Theo Dassen en ook door Dianne Engels werd explorerend $k$ walitatief onderzoek verricht betreffende de stoelgang als verpleegprobleem. 
Eveneens mijn dank aan de collega's in her hoger beroepsonderwijs in de verpleegkunde: mw, drs. W. Loor -Netjes, drs. ir. F. Woudenberg en studenten van (tegenwoordig) de Hogeschool Midden-Nederland, te Leusden.

Waardevolle ondersteuning heb ik ondervonden van mw. Marjan Tilly, die veel handmatig coderingswerk uitvoerde en de documentatie nauwgezet bijhield. De talrijke statistische bewerkingen van het onderzoeksmateriaal werden aanvankelijk door mw. Ans Huyben, later door mw. Truus Custers verricht met onuitputtelijk geduld en voorbeeldige volharding.

Nadrukkelijk gaat ook mijn dank uit naar de patiënten, de ex-patiènten en hum gezinsleden, en naar de gezonde participanten in de deelonderzoeken. Gesprekken met hen hebben mij steeds meer overtuigd van de relevantie van dit promotie-onderzoek.

Veel dank tenslotte, en niet in het minst, aan Annemarie die mij het schrijven en studeren mogelijk maakte. En aan Marieke en Anne die tot op hoge kinderleeftijd het fenomeen 'op vakantie gaan' slechts kenden vanuit de verhalen van klasgenootjes. 


\section{Curriculum vitae}

Harry van der Bruggen werd op 14 juli 1943 geboren te Bergen op Zoom, waar hij ook lager en middelbaar onderwijs genoot.

In 1970 - '74 volgde hij, in Roosendaal, een beroepsopleiding tot verpleegkundige. $\mathrm{Na}$ een half jaar arbeid in een van de ziekenhuizen in Londen, studeerde hij verplegingswetenschap aan de Université de Lyon II, met als een van de hoofdvakken maatschappelijke gezondheidszorg, en ethnopsychiatrie als een van de bijvakken: Het diploma werd behaald in oktober 1976 .

Van april 1977 tor augustus 1980 was hij als stafdocent werkzaam aan de Hogere School voor Gezondheidszorg in Leusden-C., met als opdracht de introductie van het vak nursing research in de meeste van de hogere beroepsopleidingen binnen de H.S.G.

In 1979 - '80, toen de afstudeerrichting Verplegingswetenschap werd voorbereid, vervulde hij een extern consulentschap voor de Algemene Faculteit van de Rijksuniversiteit Limburg. Vanaf augustus 1980 is hij als universitair docent, verbonden aan de vakgroep Verplegingswetenschap, werkzaam bij de Mastrichtse universiteit, waar hij een doctoraal in de gezondheidswetenschappen behaalde in juni 1985.

Harry van der Bruggen is auteur van Leve de zieke; Een antropologie van ziek zijn en verplegen $\left(1981^{2}\right)$ en Naar een antropologische verpleegkunde (1987), alsook co-auteur en eindredacteur van De delta van de Nederlandse verpleging $\left(1989^{2}\right)$, alle verschenen bij De Tijdstroom. 


\section{Stellingen}

1. Zolang in de gezondheidszorg het begrip privacy beperkt blijft tot bescherming van persoonsgegevens en databestanden, blijft de patiënt 'in zijn hemd staan'.

2. Voor vrouwen is het gemak vaak een ongemak.

3. De door de verpleegkundige verkregen anamnestische informatie van de patiënt is betrouwbaarder naarmate de patint meer gezondheidsproblemen heeft.

4. Gezien de reacties van ziekenhuispatiënten dient aan het gebruik van de ondersteek verpleegkundig meer aandacht te worden besteed.

5. Het 'normale defecatiepatroon' bestaat niet; alls referentiepunt ten behoeve van verpleegkundige diagnose en interventie moet tenminste gedifferentiëerd worden naar geslacht en leeftijd.

6. Het empirische onderzoek in de verplegingswetenschap zou winnen aan waarde en belang als de bestudeerde onderwerpen eerst tot object van historisch en fenomenologisch onderzoek gemaakt zouden worden.

7. In onze tijd van groeiende behoefte aan zelfzorg moeten diep-spoel wc's definitief tot het verleden gaan behoren.

8. Verpleegkundigen overschatten de mate waarin zij in staat blijken typische problemen van patiënten vast te stellen als angst, pijn, problemen met de voeding, slaapstoornissen, gebrek aan zelfzorgvermogen, of privacybehoefte.

9. Oriëntatie op of inspiratie vanuit het holisme vormt een belemmering voor de hedendaagse verpleegkunde bij haar ontwikkeling tot een wetenschappelijke discipline.

10. Aangezien kwantificeerbaarheid een van de kwaliteiten van de dingen is, is het onderseheid tussen kwantitatief en kwalitatief onderzoek aanvechtbaar.

11. Over dit proefschrift kan moeilijk serieus gesproken worden. 